Florida International University

FIU Digital Commons

FIU Electronic Theses and Dissertations

University Graduate School

2-27-2019

\title{
Japan's Relations with Muslim Asia: Trans-Continental Normativity and Policy
}

B. Bryan Barber IV

Florida International University, bbarb013@fiu.edu

Follow this and additional works at: https://digitalcommons.fiu.edu/etd

Part of the Asian Studies Commons, and the International Relations Commons

\section{Recommended Citation}

Barber, B. Bryan IV, "Japan's Relations with Muslim Asia: Trans-Continental Normativity and Policy" (2019). FIU Electronic Theses and Dissertations. 4058.

https://digitalcommons.fiu.edu/etd/4058

This work is brought to you for free and open access by the University Graduate School at FIU Digital Commons. It has been accepted for inclusion in FIU Electronic Theses and Dissertations by an authorized administrator of FIU Digital Commons. For more information, please contact dcc@fiu.edu. 


\title{
FLORIDA INTERNATIONAL UNIVERSITY
}

\author{
Miami, Florida
}

\section{JAPAN'S RELATIONS WITH MUSLIM ASIA: \\ TRANS-CONTINENTAL NORMATIVITY AND POLICY}

A dissertation submitted in partial fulfillment of the

requirements for the degree of

DOCTOR OF PHILOSOPHY

in

INTERNATIONAL RELATIONS

by

Bill Bryan Barber 
To: Dean John F. Stack, Jr.

Green School of International and Public Affairs

This dissertation, written by Bill Bryan Barber, and entitled Japan's Relations with Muslim Asia: Trans-Continental Normativity and Policy, having been approved in respect to style and intellectual content, is referred to you for judgment.

We have read this dissertation and recommend that it be approved.

Thomas A. Breslin

Ronald W. Cox

Steven Heine

Mohiaddin Mesbahi, Major Professor

Date of Defense: February 27, 2019

The dissertation of Bill Bryan Barber is approved.

Dean John F. Stack, Jr. Green School of International and Public Affairs

Andrés G. Gil

Vice President for Research and Economic Development and Dean of the University Graduate School

Florida International University, 2019 


\section{ACKNOWLEDGMENTS}

When the dust settles, I am going to have three new letters after my name, but truthfully, this accomplishment was achieved due to the steadfast support I have received. First, I would have never pursued a doctoral degree without the consistent support by my mother, Kristi Bode. She epitomizes tenacity. Second, I could have never pursued a doctoral degree without the consistent support by my wife, Eriko Barber. She epitomizes patience. Third, perhaps I should have never pursued a doctoral degree for the sake of my son, Will Barber. He did not consent to this adventure in life, but he always brought me joy in the most challenging of times.

My gratitude also extends to my dissertation committee members. Notably, I am deeply grateful to my advisor, Dr. Mohiaddin Mesbahi. When I first came to FIU, for a host of reasons it seemed unlikely we would have the chance to work together, but as destiny had it, the opportunity arose, and I have learned so much from him. To this day, I fail to understand why he was willing to take me under his tutelage, but I am forever grateful. I am also grateful to dissertation committee member and my former M.A. advisor, Dr. Steven Heine. On paper, it is intimidating in how erudite of a scholar he is, but in person he has always been an honest mentor and a friend. My appreciation extends to my two other committee members, Dr. Thomas Breslin and Dr. Ronald Cox, who I could count on to give thorough treatment to this project, and indispensable perspectives on how to sharpen it. The quality of this dissertation was amplified considerably due to their feedback and patience.

I would also like to use this opportunity to show my appreciation to several scholars in Japan who offered their advice and assistance for this project. They include 
the inexhaustible writer on Islam and Director of the Center for Contemporary Islamic Studies in Japan, Dr. Miyata Osamu, Dr. Usuki Akira of Japan Women’s University, Sorimachi Masayuki of the Japan Ministry of Foreign Affairs' Second Middle Eastern Division, Yagi Masanori of Asian Community Center 21 and retired from the Japan Ministry of Foreign Affairs, Dr. Oscar Gomez and Dr. Kawaguchi Chigumi of the JICA Research Institute, and Dr. Nukii Mari of the Japan Institute of International Affairs. On this side of the Pacific, I am very thankful for the opportunities provided to me by Stephen Madsen and his team at LJC America in Salt Lake City, and Dr. Sonya Nieves from Broward College. Also, the Consulate General of Japan in Miami has also been instrumental in providing a network of connections.

Furthermore, I would be remiss without extending my deep appreciation to the Mohsin and Fauzia Jaffer Center for Muslim World Studies, in the Green School of International and Public Affairs at FIU. The Jaffer Center provided financial assistance in several cases, including a research trip to Tokyo, but the Jaffer Center also facilitated a gathering of scholars eager to broaden dialogue on Islam and global affairs. Through the Jaffer Center, I was given ample opportunity to present this work and discuss it with scholars of Islam who provided insightful perspectives and showed a keen interest in the project. I am eager to see the developments at the Jaffer Center in coming years. 
C Copyright 2019 by Bill Bryan Barber

All rights reserved. 


\author{
ABSTRACT OF THE DISSERTATION \\ JAPAN'S RELATIONS WITH MUSLIM ASIA: \\ TRANS-CONTINENTAL NORMATIVITY AND POLICY
}

by

Bill Bryan Barber

Florida International University, 2019

Miami, Florida

\title{
Professor Mohiaddin Mesbahi, Major Professor
}

In 2006, Japanese Foreign Minister Asō Tarō outlined a new pillar of Japan's foreign policy across Asia he called the 'Arc of Freedom and Prosperity.' The Arc would become the most lucid case for values-based diplomacy elaborated by Tokyo in the postwar era. It is a significant change from what was both a constrained and myopic approach for a state of such global economic influence and substantial diplomatic potential. In practice, however, is Japan's values-based diplomacy actually working? How is Tokyo grappling with reconceptualizing an Asia inclusive of Muslim societies in a time when the global metanarrative is to protect against Islam?

Emphasis in this project is placed on Tokyo's foreign policy with Muslim states along this Arc. The key research question in this project is: "How does Japan's new conceptualization of Asia reconcile with its securitization of Islam?" Based on the two variables set in the research question, the project is divided into two parts:

'Conceptualization,' and 'Strategy.' 'Conceptualization' seeks to grasp Japan's vision for Asia, and its role in the region. 'Strategy' builds on that, and surveys Japan's relations with Muslim Asia through five facets of interactions. 
This project relies heavily on three types of data sources: statements from political elites, influential think tanks in Japan, and leading Japanese academic scholars. Of particular value among statements from political elites are those from the Prime Minister's office and the Ministry of Foreign Affairs. Primary sources in the Japanese language and intended for Japanese readers are used as a research tool. Content analysis software is utilized to analyze and code texts within cases from these sources to reinforce the strength of the arguments made. By applying typological theory to refine conclusions from observations, this project shows that Japan's securitization of Islam is distinct from Western, Russia, or Chinese securitization. Moreover, it demonstrates four concurrent views of Islam in Asia evident in Japan's foreign policy and strategy. 


\section{TABLE OF CONTENTS}

CHAPTER

PAGE

PART ONE: CONCEPTUALIZATION

1

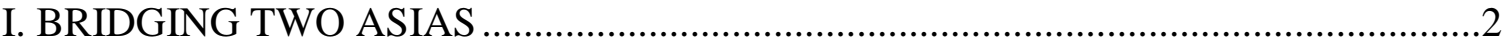

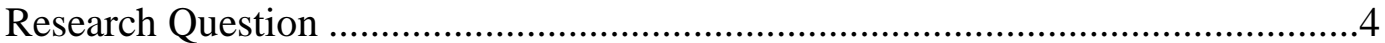

Conceptualization of Outcome Variable..............................................................12

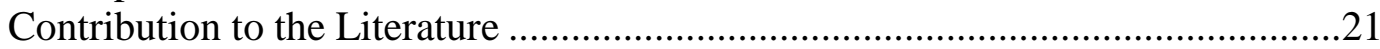

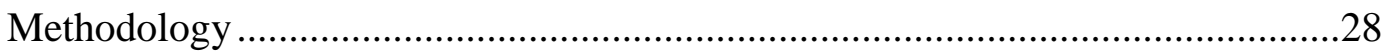

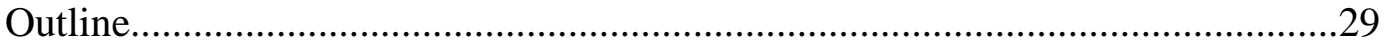

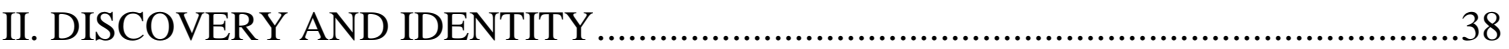

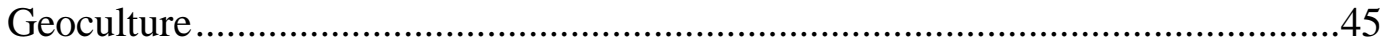

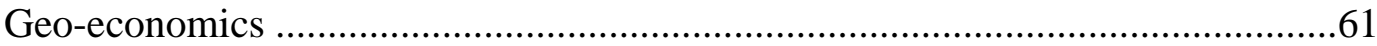

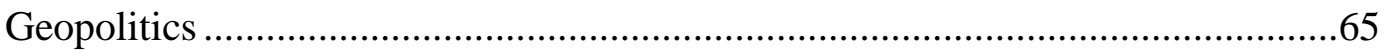

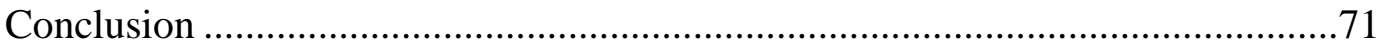

III. INTERNATIONAL AND DOMESTIC CONTEXT ……...............................................

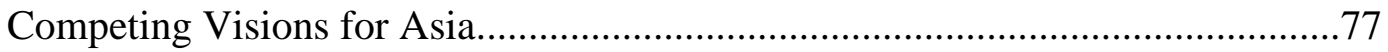

Domestic Political Factors to Values Diplomacy ……….....................................97

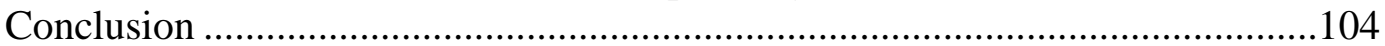

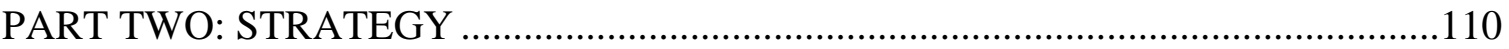

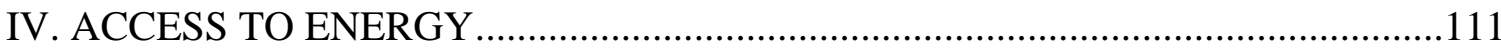

Background: A Symbiotic Relationship ……………....................................113

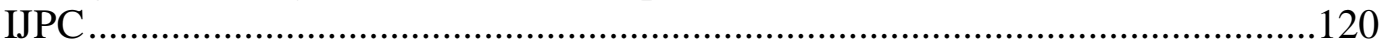

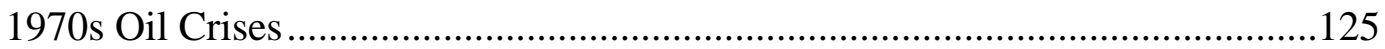

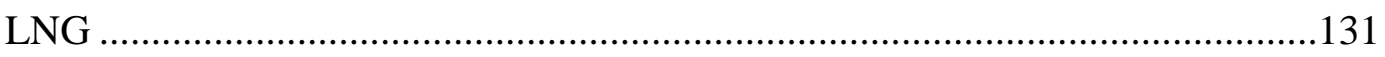

Japan's Essential Suppliers ..........................................................................134

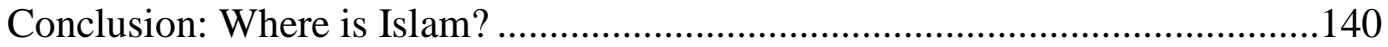

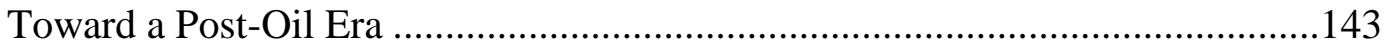

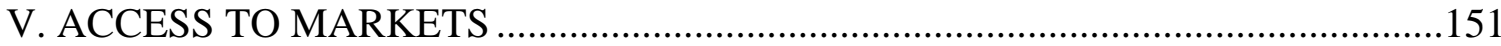

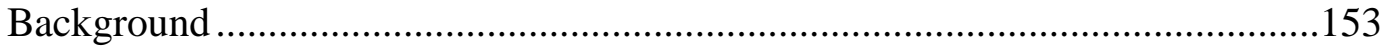

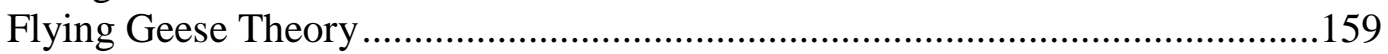

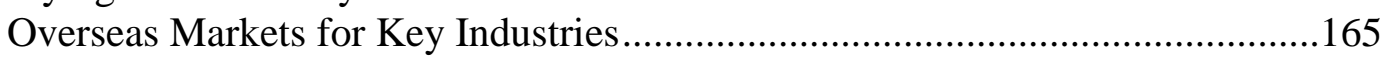

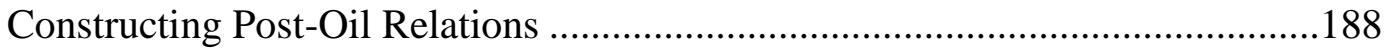

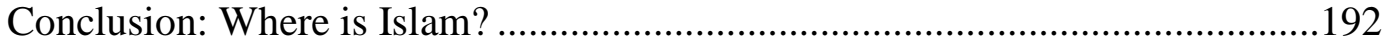




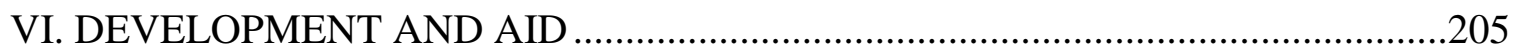

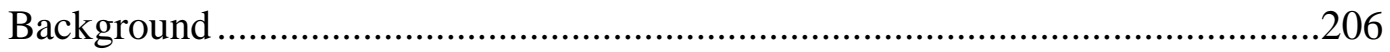

Riba, Yen Loans, Morality, and Normativity ………….................................219

Southeast Asia: The First Recipients ……………....................................222

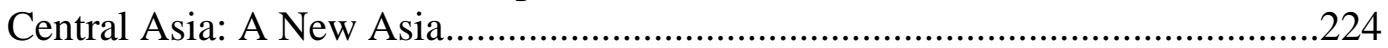

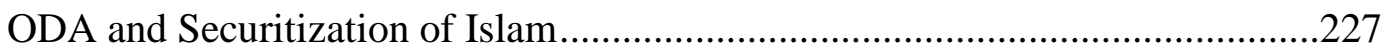

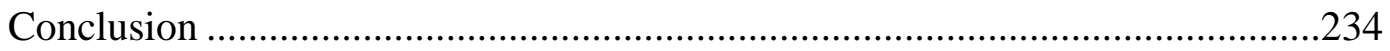

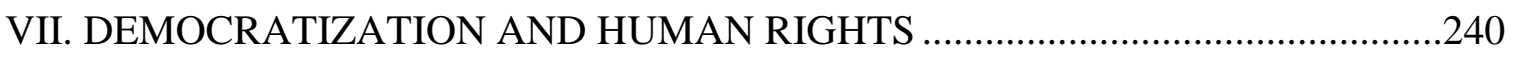

Development of Democracy and Human Rights in Japan .................................242

Human Security, as a Foreign Policy Value .......................................................2.250

Contemporary Values Conceptualizations in Foreign Policy ..............................254

Conduit for Dialogue and Leadership.............................................................268

Human Rights and the Syrian Refugee Crisis.................................................278

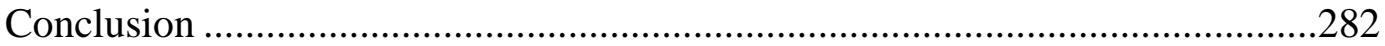

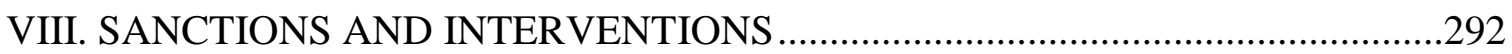

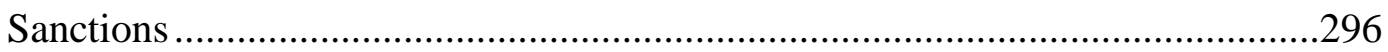

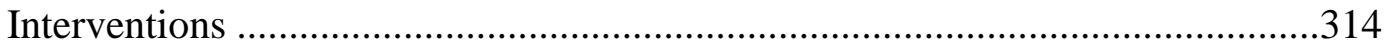

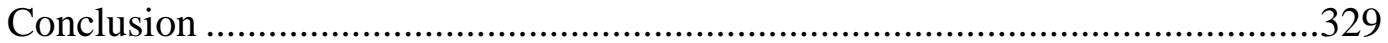

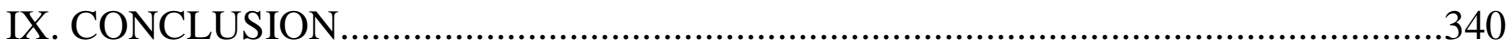

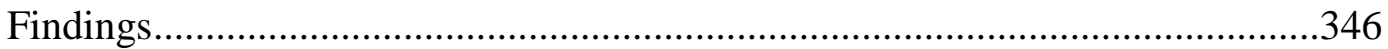

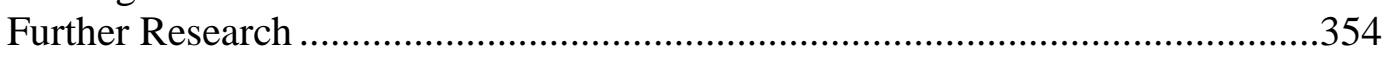

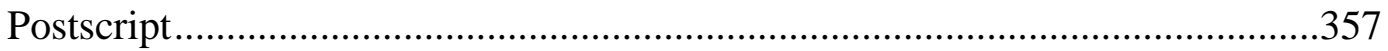

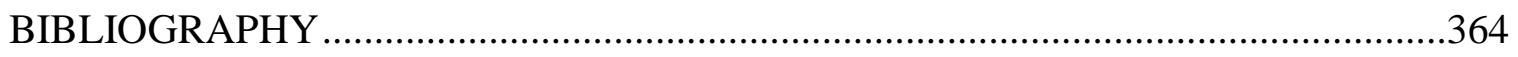

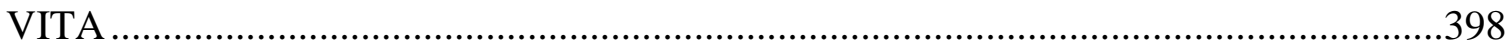




\section{LIST OF TABLES}

TABLE

PAGE

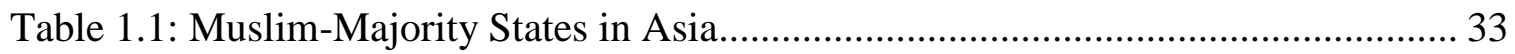

Table 1.2: Muslim-Minority Populations in Asia ...................................................... 34

Table 2.1: Population Estimate of Muslims in Japan by Nationality, 2017 ................... 76

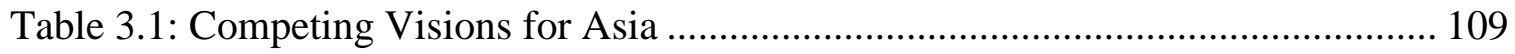

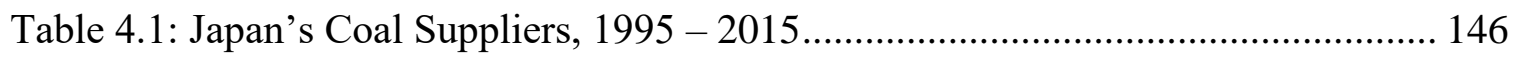

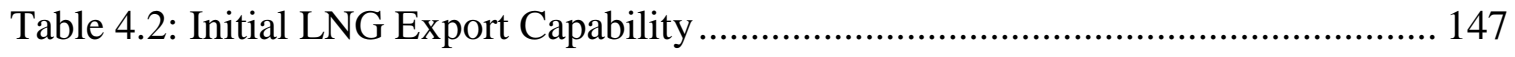

Table 4.3: Japan's LNG Suppliers, 1995 - 2015 ................................................... 148

Table 4.4: Japan's Crude Oil Suppliers, 1995 - 2015 ............................................ 149

Table 4.5: Supplier Relationship with Japan .................................................... 150

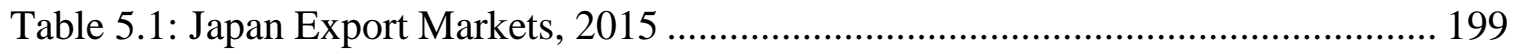

Table 5.2: Largest Trade Partners in Muslim Asia, 2016 .......................................... 200

Table 5.3: Largest New Auto Sales in Muslim Asia Markets .................................... 201

Table 5.4: Muslim Tourists to Japan by Nationality, 2016......................................... 201

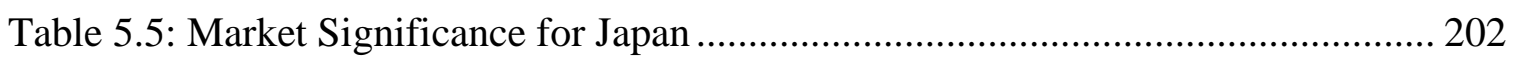

Table 6.1: Largest Recipients of Total Japanese ODA, 2015 ................................... 238

Table 6.2: Largest Recipients of Japanese Bilateral Grant Aid, 2015 .......................... 238 
Table 6.3: Japan's ODA Charters Word Frequency (percentage)

Table 7.1: Japanese Elites' References to Democracy in Muslim Asia, 2013-2018 ...... 286

Table 7.2: Japanese Elites’ References to Human Rights in Muslim Asia, 2013-2018 . 287

Table 7.3: Japanese Elites' References to Rule of Law in Muslim Asia, 2013-2018..... 287

Table 7.4: Appearance of Terms in Strings in Japan Diplomatic Bluebooks,

2013-2017 288

Table 7.5: Utterance Frequency of Select Terms by Japanese Elites' in Muslim Asia, 2013-2018 289

Table 7.6: Comparison of Japan and U.S. Voting Records on UN Resolutions Regarding Israel and Palestine. 290

Table 7.7: Central Asia Plus Japan Dialogue Foreign Ministers' Meeting Joint Statement References to Democracy or Human Rights, 2004-2017 291

Table 8.1: Iranian Crude Export Destinations (thousand bbl/d) 337

Table 8.2 Oil Consumption Jan. - Jun. 1990. 337

Table 8.3: Major SDF Deployments 338

Table 8.4: Competing Roles Evident in the Japanese View on Interventions 339 


\section{LIST OF FIGURES}

\section{FIGURE}

PAGE

Figure 1.1: Research Hypothesis 35

Figure 2.1: Reactionary Relations between Islam and Japan 74

Figure 5.1: Flying Geese Theory Model: Transition of Dominant Economy Sector ..... 203

Figure 5.2: Flying Geese Theory Model: Transition of State Competitiveness in Individual Sector.

Figure 7.1: Abe's Framing of Asian Values, at Shared Values and Democracy in Asia Symposium, Tokyo, January 2016. 285

Figure 9.1 Evidence of Values-Based Diplomacy and Level of Democratization 361 


\section{LIST OF MAPS}

MAP

PAGE

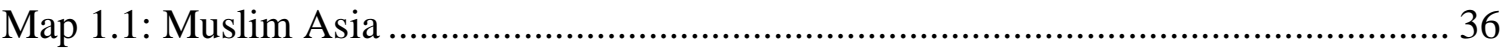

Map 1.2: Shipping Lane from Persian Gulf to Japan........................................................ 37

Map 2.1: Islamic Ummah and Japanese Archipelago in Asia ............................................ 75

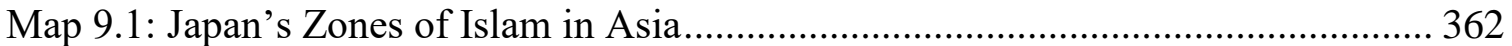

Map 9.2: Mahan's Debatable and Debated Ground......................................................... 363 


\section{LIST OF ABBREVIATIONS AND ACRONYMS}

ADB - Asian Development Bank

AIIB - Asian Infrastructure Investment Bank

BRI - One Belt, One Road Initiative

CPTPP - Comprehensive and Progressive Agreement for Trans-Pacific Partnership (replaced TPP after U.S. exit in 2017)

DAC - Development Assistance Committee

DPJ - Democratic Party of Japan (1998-2016)

EAC - East Asian Community

FDI - foreign direct investment

FGT - Flying Geese Theory

GCC - Gulf Cooperation Council

G7 - Group of 7 (1976 - 1997; 2014 - present)

G8 - Group of 8 (1997 - 2014)

JETRO - Japan External Trade Organization

JIIA - Japan Institute of International Affairs

LDP - Liberal Democratic Party (Japan)

LNG - liquified natural gas

MITI - Ministry of International Trade and Industry (Japan) (reformed into METI in 2001)

MOFA - Ministry of Foreign Affairs (Japan)

NOC - nationalized oil company

OAPEC - Organization of Arab Petroleum Exporting Countries 
ODA - official development assistance

OECD - Organization of Economic Cooperation and Development

$\mathrm{R} \& \mathrm{D}$ - research and development

SDF - Japan Self-Defense Forces

TPP - Trans-Pacific Partnership 


\section{NOMENCLATURE}

This project uses Asian nomenclature, whereby the surname is placed before the given name for Japanese and Chinese names, which is the increasing stylistic practice in American media and follows the recommendation of the Chicago Manual of Style. Authors and editors with East Asian names are listed in the bibliography in this format without a comma between. Japanese names always include macrons on long vowels, unless an author did not use macrons for the author's own name in an English-language work. The Hepburn system is used for Romanizing Japanese names and words. 
PART ONE: CONCEPTUALIZATION 


\section{CHAPTER I}

\section{BRIDGING TWO ASIAS}

In November 2006, Japanese Foreign Minister Asō Tarō outlined an expansion of Japan’s foreign policy that he called the 'Arc of Freedom and Prosperity.' Japan's foreign policy had long stood on two key pillars: the Security Alliance with the United States, and relations with neighboring states in Northeast Asia. The 'Arc,' however, would form a new pillar of diplomacy for Tokyo in addition to the existing two, and also become the most lucid case for values-based diplomacy elaborated by Tokyo in the post-War era. In his speech on the new pillar, Asō emphasized “"universal values' such as democracy, freedom, human rights, the rule of law, and the market economy" (Asō 2006b). He colorfully added, "many countries are now walking down the road to "peace and happiness through economic prosperity and democracy.' And, as I am fond of saying, this is exactly the road that Japan herself walked down after the war" (2006b). As to Japan's role in these developments, Asō analogized 'Japan will serve as an 'escort runner' to support these countries that have just started into this truly never-ending marathon" (2006b).

There is a double sense to this depiction of an Arc: firstly, it is a sanguine recasting of the phrase, 'Arc of Instability,' frequently uttered by U.S. diplomats in the first George W. Bush administration, but secondly, the new pillar to Japan's foreign policy would emphasize relations with states geographically spanning across Eurasia. Asō elaborated, "there are the successfully budding democracies that line the outer rim of the Eurasian continent, forming an arc" (2006b). He added, "take a look around the outer edge of Eurasia - just follow that line all the way around. This belt has seen great 
changes upon the end of the Cold War as the curtain was being drawn on the confrontation between East and West" (2006b). Throughout the speech, Asō listed an extensive range of regions included in the Arc: Southeast Asia, the Indian subcontinent, the Middle East, Central Asia, the Caucasus, continuing on to include Turkey and all of Eastern Europe. Asō concluded his speech with the commitment, "[i]n assisting countries as they take these steps forward, Japan aims to usher in a world order that is tranquil and peaceful" (2006b).

Momentarily setting aside disagreements with Asō's assertion that "budding democracies" are forming along this Arc, the new pillar to Japan's foreign policy is, indeed, a significant development from what was both a constrained and myopic foreign policy for a state of such global economic influence and substantial diplomatic potential. Nearly a decade later, in January 2016 Japanese Prime Minister Abe Shinzō reiterated Japan's values-based diplomacy in a speech at the Shared Values and Democracy in Asia Symposium. Abe opened with "Asia is now poised to become a champion of democracy," pointing out that "Asia's democracy has a distinct mark engraved in it from ancient times, reflecting the values we have held dear for generations" (2016). Abe outlined 'Asian democracy' as uniquely imparting values such as "lovingkindness," "benevolence," and an "utmost priority on harmony," specifically citing the roots of these values from Asian religious traditions: Buddhism, Confucianism, and Islam (2016).

Asō's pillar of an Arc of Freedom and Prosperity and Abe's Asian Democracy speech illustrate a significant widening of Japan's foreign policy which is an attempt to fortify Japan's role in Asia. Systematically, this can be explained largely by the developments of the great powers in the region. The Western-led world order has come 
into question, particularly after the 2008 financial crisis and issues of domestic friction within Western states and institutions, leaving Asian states to look elsewhere, and in particular, at their own developed states as models instead (Pehlivantürk 2016, 3). Meanwhile, Japan has been pressured by the U.S. since the first Gulf War to take a more active role in diplomacy and collective security in Asia. Additionally, the rise of a nondemocratic China encourages Japan to seek strengthening relations with states along China's periphery, and democratic norms are a key strategy and useful narrative to do so to counterbalance a rising China. Lastly, a heightened awareness of religious violence in Asia inclines Japan to 'securitize' - to carry out urgent measures in response to potential threats, thus politically elevating the imperativeness of the issue - for the sake of maintaining order in the Asian community through the promotion of stability and harmony - values key to Japan's new foreign policy pillar.

\section{Research Question}

In practice, however, is Japan's values-based diplomacy actually working? Is Japan assisting and cultivating "budding democracies" along the Arc in its own image? If Asian democracy is based on lovingkindness, benevolence, and harmony, from an Asian épistème, does it resemble anything like Western democracy? How are conflicts in Asia being securitized by Japan, while Tokyo grapples with reconceptualizing an Asia inclusive of Dharmic, Confucian, and Muslim societies? This project theorizes that normativity, via values-based diplomacy, is evident in Tokyo's foreign policy with Asian states in order to secure a leading role in Asia in light of a rising China, promote stability across the continent, and meanwhile shore up its own economic and energy security stature. A core component of this values-based diplomacy is Tokyo's own conception of 
democracy, which encompasses a tripartite distinction of human rights, pacifism, and economic development.

Emphasis in this project is placed on Tokyo's foreign policy and security policy with Muslim states along the Arc (hereafter, 'Muslim Asia') (see Map 1.1). Muslim Asia includes societies from 27 countries in the Middle East, Post-Soviet Asia (Central Asia and the Caucasus), South Asia, and Southeast Asia with Muslim-majority populations (see Table 1.1), and also those with significant Muslim-minority populations such as India, China, Russia, and the Philippines (see Table 1.2). Simpfendorfer describes Asia's Muslim population "like a spine running through the region" (2014: 52). In comparison to the other Asian states along the Arc which have stronger Dharmic or Confucian traditions shared with Japan, the attempt to conceptualize Asia inclusive of Muslim states by Japan's leaders is puzzling. This project explores this puzzle: How does Japan's new conceptualization of Asia reconcile with its securitization of Islam?

Among the predominant religious traditions which are foundations of the multiplicity of Asian societies, Indian Dharmic traditions like Hinduism, Buddhism, and Sikhism, and Chinese traditions like Confucianism and Taoism make up the essence of 'Eastern Religions.' Islam, however, is an Abrahamic religion, shared with Christianity and Judaism, yet the latter two are understood as the religious foundations to Western societies. Islam, as a principal religious tradition included in the composite of Asia, is a 'stepchild' among the other, more closely related religions, as its roots lie nearer to the Western religious traditions. Yet, "[n]o other ethnicity or religious group - whether Chinese or Indian, Buddhist or Hindu - has the same spread across the East" like Islam 
(Simpfendorfer 2014, 52). So where then does the opportunity emerge for uniquely shared values with Japan and its own societal religious foundations?

The Muslim regions are examined as the most challenging cases to be conceptualized as part of Asia, particularly given the simultaneous securitization of Islam. Securitization theory serves as a foundational theoretical framework for this project, as the securitization of Islam is most salient today in global politics. A key element of the Copenhagen School of security studies, securitization is broadly defined as:

the discursive process through which an intersubjective understanding is constructed within a political community to treat something as an existential threat to a valued referent object, and to enable a call for urgent and exceptional measures to deal with the threat (2003: 491).

Here, referent object denotes someone or something seen as having a legitimate claim to survival, yet is being perceived as existentially threatened. One or more security sectors are called upon to take action concerning the threat (not necessarily "against"), and the securitizing actor is one who declares to an audience the threat to the referent object through the use of a security speech act. In this project, while certainly not exclusively, most ordinarily the referent object is Japan as a nation-state, the audience is Japanese society, the threat is Islam, the security sectors comprise a variety including the Japan Self-Defense Force, and the securitizing actors are Japanese political leaders who utter the speech acts.

Securitization theory brings together speech act analysis with the framing of issues on a scale from nonpoliticized, to politicized, to securitized: “'Security' is the move that takes politics beyond the established rules of the game and frames the issue 
either as a special kind of politics or as above politics. Securitization can thus be seen as a more extreme version of politicization" (1998: 23). There exists an unescapable milieu in the twenty-first century that links Islam together with language of threats and security in conversation internally, regionally, and globally - what Buzan and Wæver would call "macrosecuritization," whereby "securitizations that speak to referent objects higher than those at the middle level (for example, 'universal' religions or political ideologies)" (2009: 257). In this macrosecuritization milieu, it is impossible to escape normative conversations about Islam as a religion, and Muslims as people without thinking about securitization. Therefore, how the great powers approach this is among the most salient of topics. This meta-narrative usually focuses on Western, Russian, and Chinese securitizations of Islam, yet little research is done on Japan's approach.

There is depth to the ties between Japan and Muslim Asia. Muslim Asia represents, economically, some of Japan's most vital trade relations today, and thus, some of the most vital regions for Japan. Nearly 90 percent of Japan's crude oil imports come through the Straits of Malacca (Burrett 2014, 164). Access to the shipping lanes through the South China Sea and the Straits of Malacca, bordered by Muslim-majority countries, are essential for Japanese fossil fuel imports, but most significant are relations with the states along the Persian Gulf (see Map 1.2). Eighty-one percent of Japan's crude oil imports passes through the Strait of Hormuz, with more than half coming from Saudi Arabia and UAE alone (Hirose 2015). Increased consumption by China and India and the decommissioning of domestic nuclear power plants after the 2011 Fukushima disaster have only exacerbated the significance of these imports. Similarly, Muslim states collectively make up a substantial market for Japanese exports. Simpfendorfer points out 
that "to ignore the Muslim world's role in the East's rise would be to overlook one of the region's more important commercial dynamics" (2014: 52). Both Indonesia and Malaysia make up two of Japan's top ten export markets (WITS 2017). Indonesia is additionally among the top ten recipients of Japanese foreign direct investment (FDI), and the largest of any developing country excluding China (JETRO 2014). There is the potential for a stronger relationship as a larger middle-class continues to emerge in Muslim Asia.

Considering contemporary pressures on Tokyo, how does Japan securitize Islam? Within Asia, layers of Orientalism are in effect, and Japanese are inclined to Orientalize 'Other Asia' just as much as to Occidentalize the West (Tanaka 1993, 12). Japanese Islamic scholar, Itagaki Yūzō, warns of this:

In order to shift attention and critique Japanese society today, we cannot simply reflect by borrowing the distorted glasses of Western Orientalism, but also, a critique of 'Japanese Orientalism' is needed. Before Western Orientalism was imported, Japanese Orientalism was carried over from Japanese society's continued questioning of how Self was different from China, or different from India, and thought in terms of detachment from an objectified Asia (2004: 273).

Japanese conceptualizations of identity, of Self, and Other, have a primordial nature due to its geography in relation to Asia. Japan's identity in relation to Islam in particular, however has long been filtered through other actors, albeit, different filters. The first Japanese encounters with Islam came through the centuries of attaining theological, philosophical, and philological teachings from China (Sakai 2010, 127). Islam was learned, to the extent it was learned, as part of China as the Japanese understood it. It was part of 'the China package,' and thus, it was the Other. Self was different. Japan's initial knowledge of Asia was a Sinocentric understanding, and seeing Asia beyond China meant seeing it through the filter of China simply because that was 
the knowledge available. In fact, Japan gets its name from its positioning relative to China; being to the east of China, Nihon is the 'origin of the sun.' Oddly enough, geographical knowledge of the world was greatly expanded during the Sakoku ("closed country") period in Japan, when the Tokugawa Shogunate required Dutch traders to teach the modern sciences, or rangaku (蘭学). Via rangaku, a Western schema of the continents became prevalent in geographical conceptualizations starting in the 1700 s, and were commonplace a century later (Lewis and Wigen 1997, 32). With the changes that transpired after the 1868 Meiji Restoration, Japanese begin to look at Asia through a new perspective, and through internationalization, Japan built on rangaku, bringing in a broader Western epistemological analysis to have a greater understanding of world cultures and lands. Orientalist thinking was introduced. The Japanese term for 'Orient,' tōyō (東洋), became a "geocultural notion of territoriality" (Tanaka 1993, 4). Everything that was not seiyō (西洋), or 'the Occident/West,' was conceptualized collectively as the Orient. In the early twentieth century, Japan's “Asia was the maximal Asia of Western geography" (Lewis and Wigen 1997, 72). Since then, Western conceptualization of the continents has still gained conventional acceptance in Japan (Lewis and Wigen 1997, 32). There was a tendency at the time to look at what was newly identified as 'Middle East' and 'West Asia,' incorporate these within 'Asia,' and make sense out of it in terms of Japan's sense of identity towards Asia writ large.

After a period of general enthusiasm for Western models of civilization and enlightenment which came to a peak in 1885 with intellectual Fukuzawa Yukichi's famed argument to “datsua” (脱亜), or “leave Asia," during “the Meiji twenties (1887-96)” 
scholars and policymakers in Japan began to turn back to Asia, with a raw, naïve interest in learning of Asia and learning how Japan fitted into this concept of 'Asia' (Tanaka 1993, 45). The Japanese were just beginning to learn they were Asians, and in fact, embraced it with a different conceptualization of 'Asia' from how they had understood it before. Japanese Asianist Okakura Tenshin captured the contemporary conceptualization of Asia by embracing Orientalist notions with his seminal 1904 work Ideals of the East. The book starts with the famous line, "Asia is one" (1904: 1). Okakura continues, "Arab chivalry, Persian poetry, Chinese ethics, and Indian thought, all speak of a single ancient Asiatic peace, in which there grew up a common life, bearing in different regions different characteristic blossoms, but nowhere capable of a hard and fast dividing-line" (1904: 2).

This was followed by the post-World War II period, when Asianism was "tainted by its association with Japanese imperialism and aggression" both across Asia and in Japan. ${ }^{1}$ In the new bipolar world order, Japan was now effectively part of the West on account of its new close alliance with the U.S. Japan did not only learn through Western approaches, but rather, understood itself as part of the West.

Japan sought membership with the West for much of the last 70 years, however in the twenty-first century, changes in global politics are affecting this position. Asia has emerged as the center of global economic activity and growth. Meanwhile, the U.S. encourages Japan to take a more proactive role in affairs across Asia, as it entrusts Japan to promulgate its own interests in the region. In the twenty-first century, Japan is soul-

\footnotetext{
${ }^{1}$ Some conceptualization of Asia in the pan-Asianist standpoint persisted, but was largely constrained to far-right and far-left scholars such as Tsukui Tatsuō and Takeuchi Yoshimi, respectively (Szpilman and Saaler 2011, 20-22).
} 
searching for its role in Asia, exploring opportunities to strengthen relations with Muslim states while securitizing Islam, and undoubtedly, a dearth exists in Japan regarding common understandings of these states and societies.

There is continuity in Japan's exploration to conceptualize Asia, however, and today we see a turning back to reconsider Islam as part of Asia. This view relies upon a path-dependency argument based upon the institutional sociological perspective. According to institutional sociologists, institutions "provide cognitive templates that affect identities and preferences" (Laursen 2010, 12). This accounts for continuity in foreign policy by a given state which can at times deviate from seemingly rational or objective assumptions. Institutional sociologists "pay attention to values, ideas and identities" (Laursen 2010, 12). Learning of Islam, conceptualizing Asia, and securitizing Others have gone through various filters in the past. Today, Japan explores these questions again. In the institutional sociologists' path dependency, “even when policy makers set out to redesign institutions, they are constrained in what they can conceive of by these embedded, cultural constraints" (Thelen 1999, 386). The removing and shifting of exogenous barriers in the twenty-first century has resulted in an esoteric exploration of Japan's role and identity.

This historic experience of Japanese aggression constrained postwar Japan from promoting a values-based diplomacy until the twenty-first century. Seventy years after the War, is the new model of Asian democracy viable, coming from Japan? Is it something more compatible with Islam than the model of Western liberal democracy? This project takes Asō's Arc, and analyzes Japan's relations with Muslim Asia. The regions that span Muslim Asia are generally regarded as distinguishable societies by 
Japanese and Muslims alike, with differing orthopraxies of Islam and degrees of interaction with Japan. Lastly, they have also followed very different trajectories in postcolonial history and economic development.

Many in Muslim Asia notably challenge the Western-led world order, the Western liberal democratic model, and the Westphalian concept of state, and are struggling to reconcile modernization with their religio-social milieu. Tokyo has taken note. Combined with this, there is illustrated in the aforementioned speeches a view of Japanese exceptionalism in Asia, and the possibility of Tokyo leading Asian states (as "an 'escort runner"') towards the development of Asian democracies. In the early twentieth century, Japan was referred to as a model for 'modernization without Westernization'; in the early twenty-first century, Japanese leaders are positioning themselves as a model in Asia for 'democratization without Westernization.' Combining this with the need for overseas export markets and energy imports, and responding to the rise of China, Japan has added the Arc of Freedom and Prosperity as a third pillar to its foreign policy. Japan is leveraging its identity to Asia to bolster economic security, thus tying normativity to material concerns.

\section{Conceptualization of Outcome Variable}

This project hypothesizes that disillusionment with Western-led world order in Asia, an urge by Tokyo to securitize threats from Islam, assertiveness of regional power by China, Japan's views of its own exceptionalism in Asia, and an existential preoccupation with economic and energy security collectively have resulted in this new pillar of Japan's foreign policy, the values-based Arc (see Figure 1.1). Although the Arc was presented in 2006 and the phraseology has since lost durability, the essence of the concept remains 
just as relevant, and through the foreign policy of Abe, has been more clearly refined.

The Arc is couched in consistent language by Japan's political leaders on a unique Asian geoculture, which it shares with peoples across Asia. Asianism, or ajia-shugi (アジア主 義), has been discouraged in post-War Japanese foreign policy, as Japan has sought to "de-Asianize" because "Asia symbolized disillusionment and war guilt" (Koschmann 1997, 103). Seven decades after World War II, this is changing in reaction to the evolving roles, influences, and identities throughout Asia. Japan's political leaders are avoiding and will continue to avoid - use of ajia-shugi because of its loaded meaning, but there is consistency with the early twentieth century in Japan seeing itself as an exceptional state, which can lead Asia. Koschmann aptly argues that,

It is not only an implicit belief in Japan's superiority that seems to connect contemporary Asianism with its prewar predecessor but also certain worldhistorical pretensions, according to which Japan is destined in the twenty-first century to transcend the modern era and move to the forefront of not only Asia but the world (1997: 106).

If references to Asianism are to be avoided, how do Japan's political leaders conjure images of a unique Asian geoculture, with Japan at the helm, and how is this notion conceptualized here? The remainder of this section conceptualizes this notion of 'geoculture' and how it can be applied to foreign policymaking. Asia as a geoculture is necessary to conceptualize with precision as the outcome variable in this project.

The identification of existing shared norms, values, and practices is a tool which can be revealed in crafting foreign policy between states, but where do these shared attributes come from? If two actors accept that they share cultural characteristics, and this is reason for cooperation, then they must also accept that commonality is a basis for relations which differentiate from relations with those who do not share the same 
commonality. Historical experiences can shape these identified cultural characteristics, but proximity increases the possibility of interaction, diffusion of ideas and peoples, and the likelihood of constructing a geographic entity which anchors the shared identity. Geoculture is a tool for foreign policymaking. Geoculture transcends state borders and is a perceived history and geography of likeness. Yet, while in essence a constructed concept, when used as a foreign policy tool, factual history and physical geography are the necessary impetuses to constructing a geoculture.

Geoculture is defined here as a transnational identity formed through shared norms, values, and practices, based upon shared historical experience and a mutual geographic entity. The shared historical experiences form the culture. Because geoculture is a constructed concept for foreign policymaking, cultural differences are overlooked, or downplayed, in favor of the similarities. The mutual geographic entity is a physical geographic feature such as a continent (pan-Asian geoculture), archipelago (West Indies geoculture), sea (Mediterranean geoculture), or ocean (trans-Atlantic geoculture). ${ }^{2}$ This physical geographic entity is acknowledged as shared, and anchors the identity to a base locale in the international system. Edmund Burke observed "the sentimental attachment to place is among the most elemental widespread and powerful of forces, both in humans and in animals" (Deudney 1999, 201-02). This attachment to place, labeled "geopiety"3 by cognitive geographers, is exploited to shape the modern nation-state, but there is no reason foreign policy scholars should assume it does not, or cannot, transcend arbitrary state boundaries. Deudney defines geopiety as "an identity and loyalty based on the

\footnotetext{
${ }^{2}$ This list is by no means exhaustive: others can include a peninsula, island, isthmus, lake, gulf, et cetera.

3 Also known as “topophilia” (Tuan 1974).
} 
experience of and feeling of connectedness to a particular place or area" (1996: 131). Indeed, the construction of 'bonds' based on these shared physical places is an important, yet overlooked aspect of foreign policymaking.

In order to comprehend the concept of geoculture, it is imperative to develop "contrast-space" in relation with more widely acknowledged concepts (Gerring 2012, 127), such as "civilizations" (Huntington 1996), "security complexes" (Buzan 1983, 1991: Buzan, et al. 1998: Buzan and Wæver 2003), "political communities" (Deutsch, et al. 1957), and "security communities" (Adler and Barnett, eds. 1998). To address all related terms at once, these tend to deal with global politics in general. In contrast, geoculture should be thought of as a foreign policy tool - an attempt to bond states by underlining commonalities. Unlike Huntington's civilizations, there is no theory of an inevitable "clash" between geocultures. In contrast to the variations of 'security complexes,' regions are significant variables but regional security threats are of interest in these approaches, while cultural identities, as applied in foreign policymaking, are overlooked.

Adler and Barnett's 'security communities,' which is a noteworthy revival of, and revision to Deutsch's 1957 notion of political communities, is perhaps the closest concept among the abovementioned to geoculture, but varies in two key ways. Firstly, 'region' is used in the most liberal sense possible, allowing for "imagined regions" which "are not dependent on inhabiting the same geographic space" (Adler and Barnett 1998b, 33). The examples Adler and Barnett give are the U.S.-Israeli relationship, or Australia and the West (1998b: 33). Japan's relation with the U.S. certainly suits this depiction as well. This is acceptable as a "community," which need not be anchored by a physical 
geographic entity, but not for a geoculture. Secondly, security communities are cemented through communication processes and transaction flows (Adler and Barnett 1998a, 7). Constructing a geoculture through foreign policymaking can lead to increased communication processes and transaction flows, but a reversal cannot be achieved; a geoculture refers back to a perceived shared historical experience which developed the norms, values, and practices (such as communication process and transaction flows). There is more fecundity to one's identity in geoculture, via shared historical experience and geopiety, than in one's security community, via communication process, which are increasingly global, and transaction flows, which are presumably current and short-lived. Immanuel Wallerstein coined the term 'geoculture' "by analogy with geopolitics," and uses it as a key variable in his seminal World-Systems Theory (1991: 11). It is imperative to clarify, however, the conceptualization of geoculture used here as an outcome variable varies considerably from Wallerstein's conceptualization. Wallerstein argues that by the end of the nineteenth century, a modern world-system covered almost all societies in the world. His world-system "is characterized by a system-wide axial division of labor and system of stratification, multiple political centers which, over time, take the form of nation states organized into a nation-state system and, in the nineteenth century, a dominant culture or 'geo-culture"” (Kennedy 2012, 902). In Geopolitics and Geoculture, Wallerstein argues geoculture "represents the cultural framework within which the world-system operates" (1991: 11). In World-Systems Analysis Wallerstein further explains geoculture as "norms and modes of discourse that are widely accepted as legitimate within the world-system" (2004: 93). He adds that "a geoculture does not come into existence automatically with the onset of a world-system but rather has to be 
created" (2004: 93). Wallerstein's modern world-system is predicated on a notion that sovereignty vested in the people was "meant to include, [but] in practice excluded very many" (2004: 60).

Wallerstein's notion of geoculture differs primarily in three ways. First, Wallerstein's geoculture is used in the singular. While he does not deny other geocultures could exist or have existed in the past, the modern world is a singular geoculture which includes the core, the semi-periphery, and the periphery. Second, Wallerstein never applies geoculture beyond the scope of his World-Systems Theory, and certainly not in the context of foreign policy analysis. Last, Wallerstein's geoculture is driven by his epistemological understanding of the global political economy. Thus, the global economic system necessitates a single geoculture. This is neither an endorsement nor critique of Wallerstein's conceptualization of geoculture, but it is important to clarify that his notion has little in common with a second, and developing conceptualization of the term, which is the pith of this project.

When geoculture is evoked in research on foreign policy analysis, it tends to appear in a methodological tripartite symbiosis with geopolitics and geo-economics (see Figure 1). In a groundbreaking work on the concept of geoculture, Vyacheslav Kuznetsov writes

[a]s a methodology geoculture ensures continuity of geopolitics and geoeconomics. We have in view the movement from the balance of forces (geopolitics) to the balance of interests (geo-economics), to the balance of trust and cooperation on the basis of a respectful dialogue (geoculture) (2003: 590).

Others see interactions among the three variables working in all directions, and not necessarily like Kuznetsov’s three-step transitional approach. Mesbahi applies the 
approach with the three variables working simultaneously on Russian, Turkish, and Iranian foreign policy in Post-Soviet Asia. He argues the advantage of this symbiotic approach is that it is a "multidimensional conceptual framework" within which complex dynamics "can be situated and framed" (2010: 165). Rozov uses the approach on the history of Russian foreign policy, concluding that the three "are all very tightly connected," however, "each of them is an autonomous dynamic sphere that cannot be reduced to anything else, and has its own logical patterns" (2012: 25). Davutoğlu uses the framework to assess the formation of Western Civilization:

[t]he historical emergence of a civilizational space has three preconditions: a geopolitical zone suitable for the security and basis needs, geo-economic zone for the integrity of economic activity, and geo-cultural milieu for the consistency and continuity of cultural life (2014b: 88).

While Davutoğlu's project differs from foreign policy analysis, it is appropriate that Davutoğlu uses the term "milieu" here with geoculture, as it implies an internalized interaction between the external social and physical environs.

Geoculture is a foreign policy tool leveraging basic realities of time and space; 'nuggets' of history and geography can be appropriated, and if eloquently and convincingly presented, accepted to form a geoculture. Given geoculture is a portmanteau of "geography" and "culture," each is a necessary attribute. Geographic identity is clearly represented in the term. This is not to indicate a shared topography (i.e., desert, mountains, tundra, etc.); rather, a shared physical geographic entity (i.e., continent, archipelago, sea, ocean, etc.). The shared historic experience is based on social narratives of statehood, struggle, war and reconciliation, and the diffusion of populations, knowledge and ideas. To what degree a Japanese foreign policymaker is convincing with 
a construction of an Asian geoculture varies. What is conceptualized here is the material plausibility of constructing a geoculture to apply into foreign policymaking. The material plausibilities can only come from seed elements of factual historical experiences and physical geographic entities which are recognized as mutual, and form the basis of coconstitutive shared norms, values, and practices.

This is not to advocate that 'Asia' is a reality outside of human construction. Geographers have never been consistent with how they define continents. This project is sympathetic to the work by Lewis and Wigen (1997) that debunks the reification of the world's continents, namely the partitioning of Europe and Asia (and Africa). The defining characteristics of a continent have come to be prescribed, firstly, in the physical geography as a discernable land mass and, secondly, the geology of a granitic crust plate. Yet, with a 600-mile artificial line drawn along the Urals and the Caucasus, the conventionally understood distinction between Europe and Asia is a glaring anomaly to these rules (Lewis and Wigen 1997, 35). Nonetheless, what is relevant is how Japan conceptualizes Asia.

Germane to Japan's conceptualization of the continents, and Asia specifically, is that there are two terms in Japanese which translate to "continent" in English, shū (州) and tairiku (大陸). Shū (occasionally, taishū) implies parts in a system, whereas the riku in tairiku implies land. Therefore, shü tends to take on the more (geo)cultural meaning whereas tairiku tends to take on the more geophysical meaning. Moreover, tairiku is usually used dichotomously with shima (島), or 'island.' Thus, Japan, itself is not part of any tairiku. Yürashia, or 'Eurasia' is the conventionally accepted tairiku, while $a s h \bar{u}$ (亜 
州)/ajia (亜細亜) or ‘Asia,' and ōshü (欧州)/yōroppa (欧羅巴) or ‘Europe,' are conventionally accepted taish $\bar{u}$. Japan is near yürashia, but not conceptualized as part of it. It is, however, conceptualized as part of ashülajia. While the schema of continents in Japan is just as problematic as the schema of continents in the West, this linguistic division of $s h \bar{u}$ from tairiku helps to free the geocultural from the geophysical definition, and open it up even more so to ideational construction.

A constructed Asian geoculture is Tokyo's foreign policy tool for its values-based diplomacy. Sato and Asano argue, "[t]he end of the cold war and the 'third wave of democratization' that followed offered a grand opportunity for Japan to place democratic norms into the core of its aid policy" (2008: 112). In post-Soviet Asia, public infrastructure is dilapidated; Afghanistan, Iraq, Syria, and Yemen are war-torn; most people in South Asia live in poverty. All can benefit from the particular forms of aid at which Tokyo excels, such as public infrastructure 'yen loans,' grant aid, and technical assistance (Kawato 2008, 19). Moreover, Muslim Asia is Asia, and Asō's and Abe's speeches illustrate a geocultural affinity Japan has towards fellow Asian states. Also, while Japan has broadly shown normative interests in development across Asia, these particular Asian states in the Middle East, South Asia, and Post-Soviet Asia were not directly affected by Japanese expansionism and aggression in the early twentieth century, and thus, do not carry the same degree of distrust or animosity seen in East and Southeast Asia. The Middle East, South Asia, and Post-Soviet Asian states are ones which present a fresh opportunity for Japan's values-based diplomacy - places where Tokyo can easily take the "escort runner" role Asō analogized, and assist with development and democratization. 


\section{Contribution to the Literature}

Existing literatures tend to treat the relationship between material and normative interests in foreign policy differently than this project. Realists discount normativity in foreign policy as either insignificant or underscoring some power-securing strategy, and while neoliberals and Marxists certainly emphasize material interests, they also seek to proselytize their own versions of normativity. This project seeks to combine the material and normative interests, to account for a more exact picture of foreign policy. Given this project is analyzing theory which fuses normativity with a state's ontological security concerns (perseverance and stability through economic and energy security), a constructivist approach is utilized to grasp a collective identity; "language exhibits a logical structure that enables meaning” (Howell 2013, 90). The language used by Japan's political leaders is the key material for analysis, and language alluding to an Asian geoculture with Japan leading is language "product of our conceptualizations" (Kratochwil 2008, 81). Thus, the constructivist approach is best suited to find these conceptualizations of an Asian geoculture, and how it drives normative foreign policy means towards material ends. Yet, while a constructivist approach is most apt to reveal political change by emphasizing agency, as previously discussed, sociological institutionalism and its path dependency structural constraints are also applied to reveal the political consistency. Therefore, constructivism and sociological institutionalism can work to complement each other in articulating a nuanced and accurate portrayal of Japan's foreign policy, providing fair consideration for agency and structure, as well as consistency and change. 
Within the vein of geoculture, it is important to explore the related notions of 'Asian democracy' and 'Asian values.' Is it possible to find values common among all Asian societies which can lay the groundwork for a model of democracy distinguishable from the Western model, yet sufficiently akin to each other to be bestowed the title of 'Asian democracy?' Moreover, 'Asian democracy,' as a concept, directly contradicts the theory of oriental despotism, proposed by Karl Marx, and expounded on a century later by Karl Wittfogel. The theory of oriental despotism, however, is a classic example of Orientalism that has never been supported with substantial evidence, but its notoriety has contributed to an essentialized and misguided approach of binary thinking in academia: Western is to democratic, as Asian is to despotic.

The notion of 'Asian democracy' based on 'Asian values' spawned a debate in the early 1990s among certain Asian leaders. Prime Ministers Mahathir Mohammed of Malaysia and Lee Kuan Yew of Singapore were among those who argued that Asia has its own set of values which makes it incompatible with Western liberal democracy. Thus, "Asian societies can be modernized (in an economic sense), without being Westernized (in the political sense)" (Yung 2012, 268). Proponents argue "it was predominantly their Islamic-Confucian cultural values that were acting as the driving force behind Asia's tremendous economic success during the 1990s" (Mukherjee 2010, 686). South Korea's future president Kim Dae Jung and Myanmar's Aung San Suu Kyi were among those who contested the concept, arguing that liberal democratic values are universal values; "popular participation and the justness of opposition to despotic rule are principles deeply rooted in...Buddhist, Confucianist, Christian, and Muslim traditions" (Thompson 2015, 876). While much of this debate took place formally through published articles in 
Foreign Affairs and academic journals, most preeminent thinkers involved were politicians. Bell makes the pertinent point that "political actors tend to be motivated by considerations other than clear thinking, and it may not be fair to blame elderly Asian politicians for the obfuscating discourse on Asian values" (2006: 53). If Japan's political leaders are discussing 'Asian democracy' and 'Asian values,' such as Abe's 2016 comments presented in the opening of this chapter, they are to be analyzed as a constructed geoculture, regardless of realities that root the concept.

Wood points out that in Asian traditions, "the claims of community (of which the institution of the family is an integral part) are not secondary to those of the individual. Indeed, it is often the other way around" (2004: 4). This is a common assertion regarding Asian societies, if not a clichéd one. Morris-Suzuki argues that in Asia "the acceptance of Western notions of democracy has also been accompanied by a tendency to write off predemocratic, pre-modern Asia as mired in stagnation. Today, therefore, a major task is to rediscover the diversity of local values" (2009: 167). Yung makes the observations that "many of the often cited 'Asian values' were once Western conservative values," and that "the so-called 'Asian values' in the present day, just like 'the Protestant ethic' of the West in the past, will face similar challenges as Asia continues to embark on its course of development" (2012: 271). Indeed, the notion of Asian democracy is still both nebulous and contentious in the twenty-first century. What is vital in this project is how the notion is being conceptualized as part of a geoculture by the actors, and what are the values which emanate from this model. Does it have the potential for currency?

Wood adds that "Asian democracy may have antecedents that are different from those of the West" (2004: 107). Undoubtedly, this is the case, and these antecedents are 
evident in values instilled via the moral and religious épistèmai that shape the societies. References can easily be made establishing a relationship between ethical and religious épistèmai and democratic values, but the quest remains for identifying how these are shared among Asian societies, some of which have an ethical and religious épistème based on Islam, others on Buddhism, Hinduism, and in the case of Japan, Shinto. Mukherjee makes the point that "[b]ecause the proponents of the "Asian values' debate came from different cultural backgrounds, that is, Islamic, Buddhist, and Confucian, there is no single simplistic definition of the term "Asian values"” (2010: 686). He adds, "[t]his common concept of 'Asian values' could be used to strengthen a false sense of solidarity amongst the culturally heterogeneous population and prevent centrifugal forces from coming to the political forefront to keep the power of the state intact" (2010: 686). Bell takes his critique of the concept to a higher level:

The assumption that Asia has its own cultural essence fundamentally different from that of the West is, to say the least, dubious. In fact, as Tatsuo Inoue has argued, the Asian values thesis ironically owes its roots to Western intellectual imperialism, that is, "Orientalism," the very force that was being criticized by official Asian critics of human rights (2006: 52).

Undoubtedly, every society's moral and religious foundations cultivate values in such a way as to create a unique brand of democracy in practice. Questioning sufficient commonalities across the wide scope of societies in Asia, however, is certainly warranted, yet historical evidence exists that such narratives are effective, such as Japan's transformative role in defeating Russia in the Russo-Japanese War, and the effect it had on Muslim populations to resist Western imperialism. ${ }^{4}$ Societies can see themselves

\footnotetext{
${ }^{4}$ Discussed in detail in Chapter 2.
} 
vicariously take a role in events through reactionary relations - a response to the Other's relations with a third party. Thus, if Japan presents a form of development and democracy which an Asian society seeks to, and believes it can successfully emulate, 'Asian democracy' via 'Asian values' can serve as the viable narrative to attempt such a path. This project also contributes to the developing literature on the aforementioned tripartite symbiosis framework for foreign policy analysis. By using this framework and expounding upon its concept of 'geoculture,' this project contributes to an understanding of the dynamics among the three variables, and can illustrate the strengths and weaknesses of the framework approach. Every state's foreign policy is a composite of the three variables, and by deeper conceptualization of these variables and illustration of how they interact, this project can improve the durability of the framework so later scholars can utilize it for analysis in other milieus. It is hoped that this project can illustrate that normativity found in the geoculture dynamic does not necessitate a contradiction with material interests, or for that matter grand strategy, elicited from geopolitics or geoeconomics.

Lastly, this project contributes to a new range of foreign policy analysis which fits in between the space of area studies and global studies. Japan's foreign policy is usually analyzed through its relations with neighboring states in East Asia, or with the U.S. This project, however, contributes to literature on inter-regional relations, "security constellations" (Buzan, et al. 1998, 201), "security supercomplexes" (Buzan and Wæver 2003, 60), and to thought on Asia, not simply as a continent, but as an ontological base for identity construction (Katzenstein 1997, 9-12). This project is an excellent contender to suit the space of interregional/pancontinental/subglobal study, on account of the 
consequential relationship between Japan and Muslim Asia, and the elements of the tripartite framework (geopolitics, geo-economics, and geoculture) which have driven this relationship.

Muslim Asia, especially so in Post-Soviet Asia, presents a unique 'petri dish' for Japan's new values-based diplomacy in Asia. Hickok makes the point that in crafting its Eurasian Diplomacy policy in the 1990s directed towards the newly independent Central Asian republics, "[t]he Japanese felt cultural and ethnic ties to those people who shared Mongol/Northeast Asian heritage" (2000: 25). Uyama argues that with regard to Central Asia, "[t]he image of Central Asia...evoked nostalgia and exoticism, sentiments that the Japanese had traditionally projected to Asia in general" (2008: 108). Yet, interesting to this question of an Asian geoculture is how Asian is Japan, itself? As an island-nation which constrained itself from outside contact for long periods of history, overwhelmingly homogeneous, industrialized well before any other part of Asia, and with a religious tradition, Shinto, not practiced anywhere else in the world, can Japan, itself, relate to Asia? In assessing the work of influential philosopher Fukuzawa Yukichi, who was principal in the founding of modern Japan, Morris-Suzuki argues that the modern understanding of "Asia' in Japan is "not an entity of which Japan is an inextricable part, but rather an environment which Japan can choose to leave or return to without doing violence to its own national integrity" (2009: 164). Katzenstein explores this issue of Japan's identity in his seminal work on normativity in Japan's foreign policy, Cultural Norms and National Security. Katzenstein illustrates Japan's isolation through comparison with the U.S.: 
There remains an uneasy sense that too often Japan remains a stranger in the international society of states. Unlike the United States, Japan lacks abroad what it has at home: an ideology of law and a vision of the good society that motivates political action (1996: 206).

Indeed, reconciling domestic norms and practices with observed and learned ones in the international society is an ongoing challenge for Japan's identity and significant for this project, but Katzenstein's assumption overlooked Japan's political actions abroad at the time his observation was made, and is hardly representative of the developments which would ensue soon thereafter. Japan's political action is motivated by an ideology of law and a vision of the good society in order to make a world like itself through modeling, but the measures to attain and inspire these are more opaque than in the American model.

Uyama argues that key to Japan's post-War diplomacy is that "the Japanese economy could play a unique role in the development of Asia" (2008: 109). Though Katzenstein overlooks political actions abroad, he does astutely recognize that "Japan prefers to spread its influence abroad through markets. It seeks to diffuse the economic conditions and social practices that have made possible the rise of its dynamic and productive society" (1996: 206). He adds, "Japan hopes eventually to make the international society of states more recognizable to itself" (1996: 207). Nowhere is this more evident than in Asia, but why Asia? Katzenstein adds that the Japanese "seek to export to other states in Asia...institutionalized norms as well as technological innovations" (1996: 207). Thus, the Japanese archipelago is not an isolated feature from Asia; rather, it stands on the stage, as part of the whole, but something to inspire and imitate. This idea of Japan on stage for Asia to see is not entirely different from Asianist forerunner Okakura Tenshin's idea of Japan as a "museum of Asiatic civilization; and yet 
more than a museum" (1904: 3). Describing Okakura's approach, Tanaka explains:

"Japan's genius lay in its ability to adapt creatively only those Asiatic characteristics that were harmonious with its own nature; and Japan thus became the possessor of the best of Asia” (1993: 13). He adds, “it was Japan's destiny to revive Asia” (1993: 13).

Normativity is present, yet the practices of normativity in Japan's foreign policy fly under the radar for most observers.

\section{Methodology}

Is this diplomatic strategy viable in Muslim Asia? Despite vast distances, differing religio-cultural practices, and limited interpersonal contacts, can Islam be securitized, shared values be elevated through a constructed Asian geoculture, and institutions be strengthened, and thus tying normativity with material concerns? For analysis, event cases are selected among the Muslim-majority states in Asia.

The period of analysis generally spans the end of the Cold War to present, but occasionally brings in earlier material in 'Background' sections to set context. In withincase analysis, process tracing is used to detect the presence of causal process observations. In compiling data on individual cases and comparing the cases, it is important to stress the nominal nature of the cases: Data on the explanatory factors and outcome variable are to be measured qualitatively. Process-tracing "provides a check on whether the explanations developed from typological comparisons are spurious" (George and Bennett 2005, 254). Using the cases, process-tracing can potentially indicate overlooked variables, which would necessitate a heuristic reformulation of the explanatory variables in order to refine the theory. 
In order to carry out this analysis, the project will rely heavily on three types of data sources: statements from political leaders, influential think tanks in Japan, and leading Japanese scholars of Islam. Of particular worth among statements from political leaders are the Prime Minister's office and the Ministry of Foreign Affairs (MOFA). The so-called "Iron Triangle" of the Liberal Democratic Party (LDP), business community, and bureaucracy, which long dominated the political elite-class in Japan, has loosened considerably in the last two decades. Prior to this, the bureaucracy could be thought of as the singular 'think tank.' Today, several think tanks exist with varying degrees of influence on policy. Most notable is the Japan Institute of International Affairs (JIIA), which is rated the most influential think tank in Asia and affiliated with MOFA.

For cross-case analysis, the project lends itself most appropriately to typological theory, as the nuances to the explanatory variables in each case are to remain nominally qualitative, and upon analysis, can be configured into 'types.' Through noting similarities and "sharper distinctions between types," the significance of the explanatory factors on the outcome variable can be measured, and a clearer grasp of Tokyo's values-based diplomacy in practice can be assessed (George and Bennett 2005, 237). With this method, the theory can be refined and tested further with the same cases, or other cases within the scope of the study at the project proceeds. At the conclusion, cases are grouped together based on similar outcomes in a typology. This streamlines the types and diagrams them into a more precise theory (George and Bennett 2005, 260).

\section{Outline}

Milieu drives, in part, idea, and idea preempts foreign policy; strategy then follows. Therefore, conceptually, this project focuses, first, on Japan's idea, or conceptualization, 
of Asia. Conceptualization is the objective for chapters 2 and 3. Chapter 2 creates a chronology of Japan's encounters with Islam, discovery and knowledge of Islam, evolving conceptualization of Islam, and particularly, how Islam as a religion and lifestyle fits into its conceptualization of Asia. It discusses pertinent relations with Muslim Asia in a historical and regional context, and thickens with detail toward the present. How are the Japanese getting this idea of Islam? Are they arriving at this idea independently from others, or are they following others? How does this idea affect policy?

Chapter 3 sets the structural scene. Titled 'International and Domestic Context,' it includes, first, a geopolitical framing of competing and complementary grand strategies for Asia among the great powers, the U.S.'s 'Pivot toward Asia,' China's 'One-Belt OneRoad,' and Russia's 'neo-Eurasianism,' and how Japan's strategy interacts with the other three. This serves to frame the research results in the context of current power dynamics in Asia, and resultantly, can shed light on Japan's vision juxtaposed and interacting with the visions of other great powers on the continent. What is the strategy as a result of this idea, and this policy? This is then followed by clarifying the domestic political factors which are undoubtedly affecting policy and strategy by pushing this new approach. Chapters 2 and 3 search for the Japanese conceptualization of Asia, and how Islam fits into this conceptualization via three facets that connect the structure to agency. Chapter 2 is the Japanese Self conceptualization within the structure of Asia inclusive of Islam. How does the identity of Self, and perception of Other matter? Chapter 3 is the contemporary structural variables coming from the great powers, which push and pull the Japanese agency's perceptions and strategies. How does the international milieu matter? 
Then, it includes the push-pull variables in the domestic political power structure in Japan. Together, these inform how Japan proceeds with strategy in, and with Muslim Asia.

Once a firm understanding of Asia as a package that includes Islam is established, then the project proceeds to the latter half which focuses on the strategizing and operationalizing vis-à-vis policy. The second half of the project, 'Part II: Strategy,' elucidates the factors identified as significant in strategy from the first half. 'Part II: Strategy' includes 'Chapter 4: Access to Energy,' 'Chapter 5: Access to Markets,' 'Chapter 6: Development Aid,' 'Chapter 7: Human Rights Debate,' 'Chapter 8: Sanctions and Interventions,' and 'Chapter 9: Conclusion.' Chapters 4, 5, and 6 are rich with factual detail with by Chapters 7 and 8, are intermingled with outcomes and observations. Chapter 9 summarizes the findings, presents the typological theory outcome, frames the results in a broader theoretical context, and discusses further research possibilities.

This project analyzes the viability of Japan's first values-based pillar of foreign policy in the post-War era. The ramifications of the Arc, an Asian geoculture, and the notion of 'Asian democracy' are immense. This is in many ways a second attempt by Japan to take a leadership role in Asia - the first being a twentieth-century model for 'modernization without Westernization,' and now 'democratization without Westernization.' While this policy approach is in no regard an attempt at establishing hegemony across Asia, it could be interpreted as a narrative to undermine the dominant role China is taking, and Tokyo's way to distance itself from the West, and further explore its identity as part of Asia. The new policy, however, is hedging its bets on an assumption that democracy, whether it is liberal, Asian, or without a descriptive 
adjective, but as presented, appeals to Asian societies today, and is something which can serve as a cornerstone to shared identity.

The outcomes of this project can make a valuable contribution to understanding Japan's worldview, its construction of, and assumed role in Asia, and continuity and change in Japan's norms, values, and practices in foreign policy. Additionally, this project uncovers the significance and implications of the Japan-Islam relationship, thus contributing to the dearth of knowledge that exists in the dominant, Anglophonic medium in academia. The path Japan takes globally in redefining itself in light of ongoing economic stagnation, social ills, and demographic decline at home in the twenty-first century will leave lessons to be learned by all states that will inevitably face similar challenges at some point. 
Table 1.1: Muslim-Majority States in Asia

\begin{tabular}{|c|c|c|c|c|c|}
\hline & $\begin{array}{l}\text { Muslim } \\
\text { ulation (in } \\
\text { tillions) } \\
\end{array}$ & $\%$ & \multicolumn{2}{|c|}{$\begin{array}{c}\text { Muslim } \\
\text { Population } \\
\text { (in millions) }\end{array}$} & $\%$ \\
\hline \multicolumn{3}{|c|}{ South Asia } & \multicolumn{3}{|c|}{ Middle East } \\
\hline Afghanistan & 28.1 & 99.7 & Bahrain & 0.6 & 81.2 \\
\hline Bangladesh & 145.3 & 89.6 & Iran & 73.8 & 99.4 \\
\hline Maldives & 0.3 & 98.4 & Iraq & 30.4 & 99 \\
\hline Pakistan & 174.1 & 96.3 & Jordan & 6.2 & 98.2 \\
\hline \multicolumn{3}{|c|}{ Southeast Asia } & Kuwait & 2.8 & 95 \\
\hline Brunei & 0.27 & 67.2 & Lebanon & 2.5 & 59.3 \\
\hline Indonesia & 202.9 & 88.2 & Oman & 2.5 & 87.7 \\
\hline Malaysia & 16.6 & 60.4 & Palestine & 4.2 & 98 \\
\hline \multicolumn{3}{|c|}{ Post-Soviet Asia } & Qatar & 1.1 & 77.5 \\
\hline Azerbaijan $^{i}$ & 8.8 & 99.2 & Saudi Arabia & 25.0 & 97 \\
\hline Kazakhstan $^{i}$ & 8.8 & 56.4 & Syria & 20.2 & 92.2 \\
\hline Kyrgyzstan & 4.7 & 86.3 & Turkey ${ }^{i i}$ & 73.6 & 98 \\
\hline Tajikistan & 5.8 & 84.1 & UAE & 3.5 & 76.2 \\
\hline Turkmenistan & 4.8 & 93.1 & Yemen & 23.4 & 99.1 \\
\hline Uzbekistan & 26.5 & 96.3 & \multirow{2}{*}{\multicolumn{3}{|c|}{$\begin{array}{l}\text { ii The European portion of Turkey, the } \\
\text { East Thrace, makes up only three percent } \\
\text { of Turkey's landmass and with the largest } \\
\text { city, Istanbul, } 12 \text { percent of the } \\
\text { population. The majority of Turkey's } \\
\text { population and landmass, and its capital, } \\
\text { Ankara, however, are on the Asian side, } \\
\text { and thus it is considered part of Muslim } \\
\text { Asia for the purposes of this project. }\end{array}$}} \\
\hline \multicolumn{3}{|c|}{$\begin{array}{l}{ }^{i} \text { Azerbaijan and Kazakhstan are } \\
\text { conventionally considered } \\
\text { transcontinental states. Here, both are } \\
\text { included in Muslim Asia due to shared } \\
\text { political, linguistic, historical, and cultural } \\
\text { attributes with other Muslim Asia states. } \\
\text { Moreover, in both cases, a significantly } \\
\text { smaller portion of territory and population } \\
\text { are on the European side. }\end{array}$} & & & \\
\hline
\end{tabular}


Table 1.2: Muslim-Minority Populations in Asia

\begin{tabular}{|c|c|c|c|c|}
\hline & $\begin{array}{l}\text { Muslim } \\
\text { Population }\end{array}$ & $\%$ & $\begin{array}{c}\text { Significant Sub-State } \\
\text { Regions }\end{array}$ & $\begin{array}{c}\text { Significant Ethnic } \\
\text { Groups }\end{array}$ \\
\hline India & 176 million & 14.4 & Kashmir & \\
\hline China & 25 million & 1.8 & Xinjiang & Hui, Uyghur \\
\hline Philippines & 5.1 million & 5.5 & Bangsamoro & Moro \\
\hline Thailand & 3.8 million & 5.5 & Southern Border Provinces & Malay \\
\hline (Asian) Russia ${ }^{i}$ & 2-3 million & $6-9$ & & Tatar, Bashkir \\
\hline Sri Lanka & 2 million & 9.8 & Eastern Province & Sri Lankan Moor \\
\hline Myanmar & 1.9 million & 4.0 & Rakhine & Rohingya \\
\hline Israel & 1.4 million & 18.6 & Northern District & Arab, Palestinian \\
\hline Nepal & 1.4 million & 4.6 & & \\
\hline Singapore & 730,000 & 14.3 & & Malay \\
\hline$\cdot$ & $\cdot$ & . & • & - \\
\hline & & & & \\
\hline Japan & 200,000 & 0.2 & & \\
\hline \multicolumn{5}{|c|}{$\begin{array}{l}\text { i Muslims in Asian Russia (Siberia and Russian Far East), according to most } \\
\text { conventional geographical understandings of the continent's boundaries, are limited to } \\
\text { those located east of the Ural Mountains and Ural River. It does not include the North } \\
\text { Caucasus region, Tatarstan, and nearly all but a sliver of eastern Bashkortostan. }\end{array}$} \\
\hline
\end{tabular}


Figure 1.1: Research Hypothesis

$\mathrm{IV}^{1}$ : disillusionment with the Western-led world order in Asia
+
$\mathrm{IV}^{2}$ : Japan's urge to securitize Islam
+
$\mathrm{IV}^{3}$ : assertiveness of regional power by China
+
$\mathrm{IV}^{4}$ : Japan's views of its own exceptionalism in Asia
+
$\mathrm{IV}^{5}$ : an existential preoccupation with economic and energy security
$=-----------------------------$
DV: the formulation and reiteration of an Asian geoculture in Japan's foreign policy in
Asia


Map 1.1: Muslim Asia

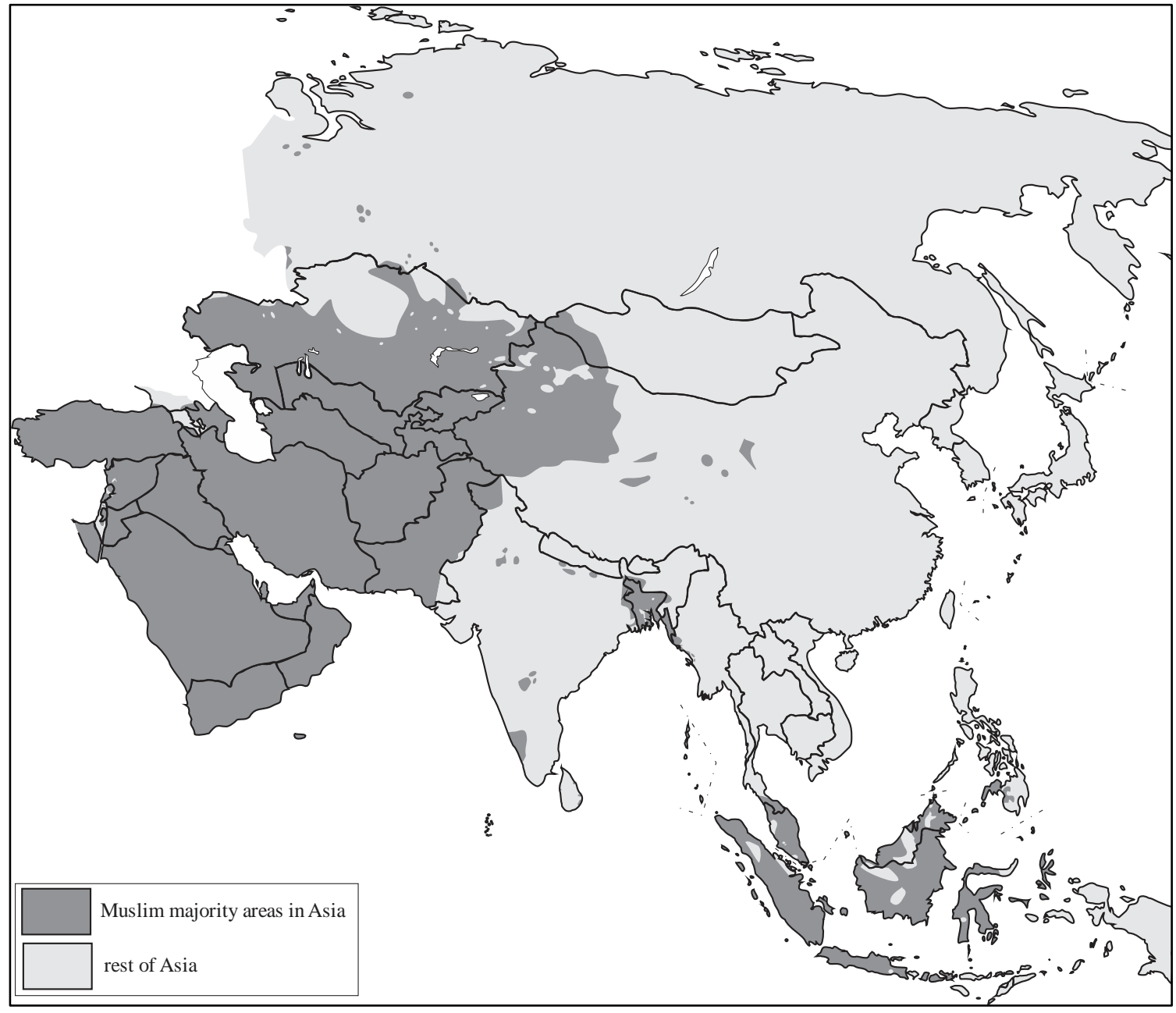

Map by author. 
Map 1.2: Shipping Lane from Persian Gulf to Japan

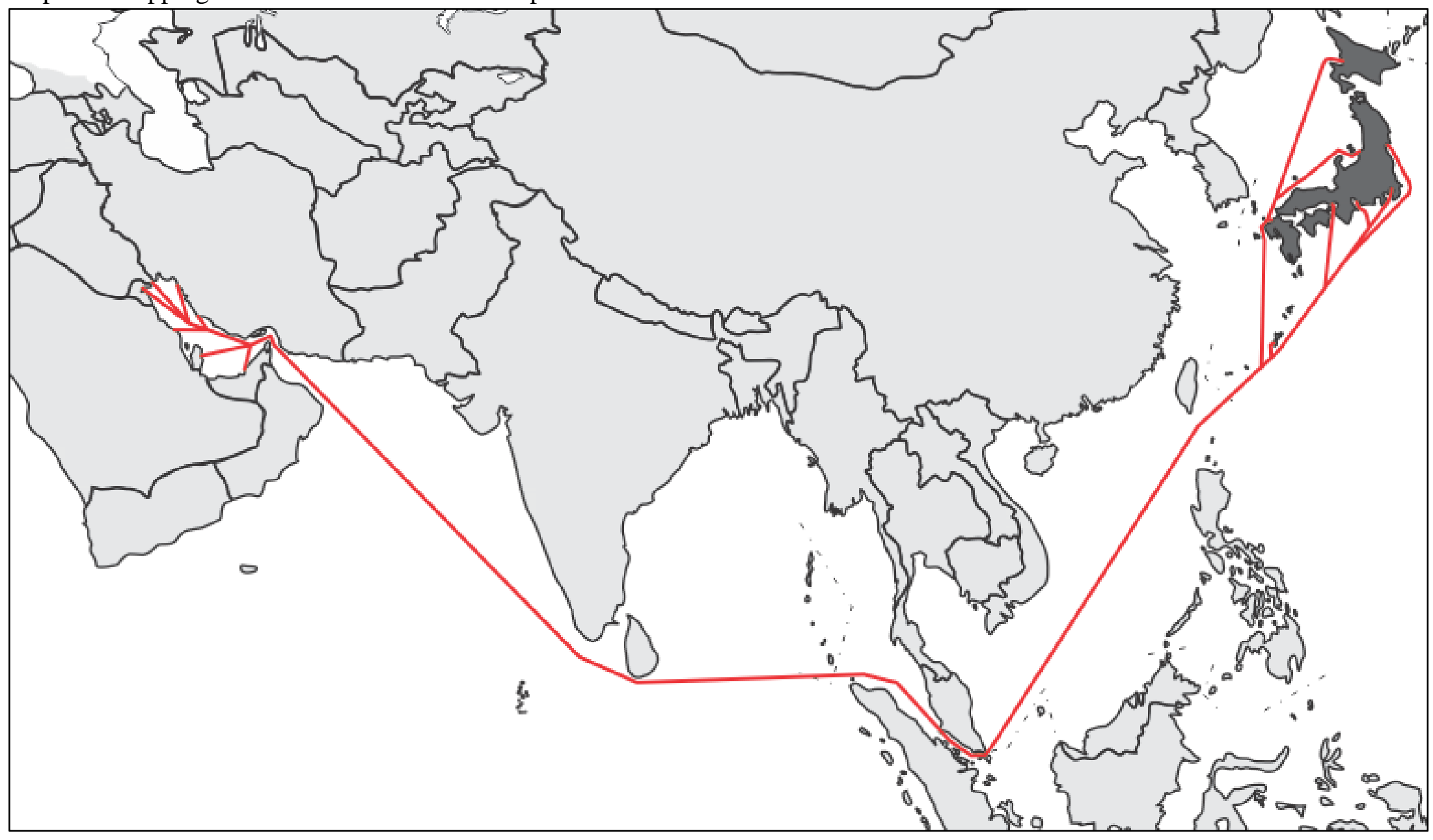

Map by author. 


\section{CHAPTER II \\ DISCOVERY AND IDENTITY}

In January 2015, two Japanese nationals were kidnapped by ISIS and eventually beheaded when the Japanese government refused to meet ransom demands by the kidnappers. Beheadings by ISIS are shocking to Westerners and Muslims alike, who have seen footage of their own symbolically dehumanized while recorded with the intention to disseminate an extremist message. For the Japanese, the act was particularly acute, since throughout the conflicts religious extremists presented against mainstream Muslims and the West, the Japanese felt some sense of security in being neither here nor there - on the periphery of the hotspots. The beheadings illustrated that while Japan is geographically and culturally distanced from Islam, it was not immune to this crisis in Islam.

This chapter explores the ideational complexity of Japan's relations with Islam throughout time and space; it explores historic interaction between the two which formed ideas of Self and Other, roles, and identities that persist. There is an abundance of literature on Islam's relations with the West, Russia, China, and other actors, but Islam's interaction with Japan has evaded substantial research. This chapter has two objectives: firstly, it seeks to explain the influence of conceptualizations of Islam on Japan's positioning within the world order since initial contact; secondly, it seeks to reveal key conceptual dynamics which shape Japan's foreign and security policy with Muslimmajority states in Asia today. Attaining a grasp of both of these objectives is essential prior to proceeding with this study. While some discussion of conceptualizations of Japan by Muslims in Asia is relevant, this chapter (and project) concentrates on the Japanese 
interpretations and reflections, as seen through foreign and security policy, in response to interactions with Islam. This chapter deepens the understanding of inter-civilizational, interfaith, and transregional relations between Japan and Muslim Asia which have helped to construct Japan's identity and role in Asia, its conceptualization of Asia, and particularly, how Islam as a religion and lifestyle for Asian societies fits into this conceptualization.

In reference to Edward Said's terminology, this seems to be a case of Orientalism by the Orientalized. Said did not identify this as a case of Orientalism because he defined the term as "a way of coming to terms with the Orient that is based on the Orient's special place in European Western experience," but in fact, how Japan learned about Islam since the nineteenth century is largely based on the European Western experience (1979: 1). ${ }^{1}$ While Japan and the Muslim world are historically and geographically remote from each other, both have constructed their identities to some extent in contrast to the West, which at times in the past has been sufficient reason to attempt coalescing identities. These coalescing attempts are in part due to Orientalized understandings, in that Self and Other are both in contrast with the West, therefore, Self and Other have a sameness. There is a rich history of interpretations of each other as the Other Orient through interaction with the West, which manifested even in the ISIS beheadings of Japanese nationals. For it was pointed out by ISIS militants that Japan joined with the U.S. in the Iraq War in 2003, and thus was an 'enemy state' collaborating with the West.

\footnotetext{
${ }^{1}$ Said does recognize, however, that Orientalism's “influence has spread to 'the Orient' itself: the pages of books and journals in Arabic (and doubtless in Japanese, various Indian dialects, and other Oriental languages) are filled with second-order analyses by Arabs of 'the Arab mind,' 'Islam,' and other myths"' (1979: 322).
} 
At first glance, relations between 'Japan' and 'Islam' appear incommensurable. Japan is a quintessential nation-state, and the most homogeneous of large and developed countries, with 98.5 percent of its populace ethnic-Japanese. It is also an island nation, a geography which has allowed it to remain isolated from globalization for centuries, sample elements of other cultures, and adapt them over time. It is democratic, polytheistic, and modern (if not post-modern). Islam is a monotheistic and universalist religion spanning across the globe, though rooted with its holy cities at a tri-continental pivot on the fossil fuel-abundant Arabian Peninsula. It has been in frequent interaction with 'foreigners' since its beginnings, and struggles to reconcile with modernization are evident today. On appearance, the two entities, Japan and Islam, are clearly not on the same level of analysis, but there is more symmetry than meets the eye. Often defining 'to be Japanese' hardly involves just a citizenship right, but is more often identified as adherence to a series of annual, and in some cases, daily rituals based on the synchronism of Shinto and Buddhism found only in Japan. Much of the work done by Ian Reader demonstrates that these practices are not done as Shinto or as Buddhist, per se; rather, they are done as Japanese (1991; 1998). Thus, observed from the perspective of religiosity rather than nation-states or civilizations, symmetry can be achieved.

Symmetry at the level of analysis can be achieved, yet treating entities at this level of analysis as agents remains challenging - particularly in the case of Islam. While Japan is a religious milieu with rituals, practices, and an épistème, it is also a nation-state with clear agency. Trying to construct Islam as agency, however, is challenging, as no political entity can justifiably represent the collectivity of states, religious sects, and ethno-societies (although there are many who would desire to do so) (Brown 2014, 56). 
This conundrum is not severely problematic, however, regarding the scope of this project since Japan is the subject of inquiry and Islam is the object of inquiry. What is significant here is how Japan, which can serve as a civilization, state, religious milieu, and agent, conceptualizes and reacts to other conceptualizations of 'Islam' in the global order.

The framing of actors as 'civilizations' can come with unwanted baggage. In the singular, the term implies a monolithic and ubiquitous standard of sophistication, usually closely associated with development, globalization, or modernization (Davutoğlu 2014a, vii). Yet even in the plural, it implies coexisting (or competing) normative social orders at best in a "dialogue," as advocated by the UN General Assembly in 1998 (Brown 2014, 57), or a "clash," as theorized by Samuel P. Huntington. Huntington's oft-cited book, The Clash of Civilizations and the Remaking of World Order (1996) has contributed greatly to the stigmatization of the concept, given its ad hoc arrangement of major contemporary civilizations. While Huntington recognizes the permeability of civilizations, he underplays this point in his work as he reified civilizations as agents, bound for confrontation. In this project, more significant than the UN General Assembly's notion, or the Huntingtonian notion of 'civilization' is how the Japanese conceptualize Islam as a foundation to a pivotal global civilization, and how this affects their framing of world order. It also affects the approaches Tokyo utilizes in past and present foreign policy with Muslim-majority states. To this point, it is useful to note there is no commonly recognized distinction in the Japanese language between the terms 'Islam,' and 'Muslim.' A ‘Muslim' in Japanese is Isuramu-kyōto (イスラム教徒) - a 'believer of Islamic teachings.' Thus, attempts to distinguish a Muslim society or person from Islam, as a 
creed, are linguistically challenging, but reinforces assumptions of civilizational conformity. $^{2}$

Dallmayr, et al. describe Davutoğlu's conception of civilizations as “distinct paradigms of human and social existence, comprising cognitive, normative, aesthetic, and spiritual aspects" (2014: $x v)$. The authors add "[c]ivilizations in this view develop distinctive perceptions of time and space [italics added], and of the meaning and purpose of human and social life" (2014: $x v)$. This view, which bases civilization upon the perception of the actor, is more aligned with how it is defined here. Within this framework of relying on the actor to define the Self and the Other (or, the Self and OtherSelf), the inter-civilizational relations between Japan and Islam can be analyzed through direct contacts, but indirect contacts are also valuable for conceptualizing their positioning in the world order. In both time and space, other actors such as Russia, China, a Hindu civilization (fundamentally represented by the Indian nation-state), and the West (through the U.S., UK, EU, G7, et cetera) interacted with Japan on the world stage while Muslims watched and reacted, and vice versa. Therefore, often the inter-civilizational relations between Japan and Islam are simply not bilateral relations, but reactionary relations - a response to the other's relations with a third party, usually among the four abovementioned entities (see Figure 2.1).

This chapter proceeds by applying a multidimensional conceptual framework within which the inter-civilizational, and reactionary relations can be framed. The

\footnotetext{
${ }^{2}$ Note this linguistic structure of applying the suffix '-kyōto' (-教徒), or 'believer of teachings' applies for most other major religions, such as Buddhist, 'buk-kyōto' (仏教徒), (believer of Buddha's teachings), Jewish 'yudaya-kyōto' (ユダヤ教徒), (believer of Jewish teachings), and Christian, 'kirisutokyōto’ (キリスト教徒), (believer of Christ’s teachings).
} 
triangular symbiotic framework is applied, addressing geocultural, geo-economic and geopolitical dynamics. Mesbahi elaborates that this framework is to be "embedded geographically in a megaregional complex," which is precisely the scope of this project (2010: 167). Geoculture drove discovery and initial identity-formation between Japan and Islam for centuries of early contacts, although not exclusively. Early twentieth-century industrialization and militarization in Japan thrust geo-economics and geopolitics into the forefront of Japan's foreign policy with Muslim Asia; postwar, however, geoculture, and to a lesser extent geopolitics, were tremendously muted. Geopolitics began its revival during the 1970s oil shocks, and in the twenty-first century, with the announcement of a values-based Arc and further systemic developments in global politics, geoculture is increasingly attaining parity in Japan's foreign policy with Muslim Asia. All three are present in foreign policy at all times, and this chapter is not to be read as a comprehensive sweep of the background that has shaped the relations between Japan and Islam today. Rather, this chapter is seeking out perceptions of Self and Other from interactions, and finds as the driver of foreign relations has shifted over time, so have the learning, surmising, and perceptions. Of the three, 'geoculture' is analyzed here in substantial detail because, firstly, it is the least clearly conceptualized and thus worthy of substantial analysis; secondly, it was historically the first driver to situate discovery and identity, which went on for centuries long before geo-economics and geopolitics took over; and thirdly, it relates more closely to the problematic concept of 'civilization.' 
Geographically, Islam has its Ummah, or supra-national community of Muslim populations, and Japan is territorially a clearly defined ${ }^{3}$ nation-state on an archipelago (see Map 2.1). While the geographies are distanced to some degree with no distinctive border zone or conflicted territory, ${ }^{4}$ they serve as integral linchpins to the Eurasian regional complex, one spanning across the southwest to southeast, and the other boxing it in from the east. The significance of these areas on the Eurasia continent was apparent to classical geopoliticians Mackinder and Spykman, but also keenly understood by policy analysts in Washington and Moscow during the Cold War. The traditional geopolitical approach is accepted in the analysis of this chapter, but confines the analysis. The symbiotic framework, however, which includes geo-economics and geoculture in foreign policy analysis, allows for examination of this inter-civilizational relationship beyond spatial zones and geo-strategic interests, thus allowing for wider dimensions of interaction through perceived geographies.

This chapter proceeds by starting with the geocultural dynamics. Extensive analysis takes place here, as the term is conceptualized and analysis expands deep into germane cases of historical interactions between Japan and Islam which construct and contribute to the present image of Self and identity in Asia for the Japanese. Geoeconomics follows, emphasizing the often-overlooked significance of the Japan-Muslim geo-economic relationship in the past and present, and how it bears on role and identity. A discussion of the geopolitical dynamics completes the symbiotic triangle, and ties it

\footnotetext{
${ }^{3}$ Save for island territorial disputes with neighboring states.

${ }^{4}$ As discussed later in the chapter, however, there is a history of territorial and geocultural overlap between these two entities that is significant in their relationship today.
} 
together with the geocultural and geo-economic dynamics. The chapter concludes with thoughts on the variables which weigh most heavily on Tokyo's foreign policy toward Muslim Asia based on identity and conceptualization as extrapolated from the preceding discussion, and reoccur in subsequent chapters.

\section{Geoculture}

Geoculture can potentially transcend societies, nations, and civilizations. The prefix 'geo-' emphasizes a spatiality to the term-a spatiality which is a cognitive geography of sharing a physical geographic entity. The 'culture' in 'geoculture' adds even more ambiguity. The very nature of 'culture' is vague and ever-changing. This looseness of the term allows it to be manipulated, and easily constructed into narratives of shared norms, values, and practices. Emphasized in foreign policy, this fleshes out an idea of shared identity. Combined with the 'geo-' prefix, the concept illustrates how constructions of place and proximity can shape understandings of culture and uniqueness. Whether geoculture is utilized as a variable in foreign policy is the decision of the policymakers. Whether it is accepted is the decision of the political leaders and populaces. The concept thrives as long as a mass of the political leaders and populace accept the narratives of shared norms, values, and practices based on shared historic experiences and a physical geographic entity.

This section examines the historical record of attempted constructions of a shared geoculture between Japan and Islam. Some of these constructions were made through reactionary relations with other actors, yet still could serve as the impetus to constructing a geoculture. These historical encounters between Japan and Islam are significant in the construction of existing identities in the international system, as well as revealing latent 
possibilities of geoculture being applied to Tokyo's current foreign policy toward states in the Muslim world.

The archaic term for 'Islam' in Japanese, kaikyō, is written with the same Chinese characters as the archaic Chinese term for "Islam," huijiào (回教). Literally, the term means "Hui teaching," as in the beliefs taught by Hui ${ }^{5}$ people of China, who are uniquely characterized by their Islamic tradition, and not necessarily their language or ethnicity. The Chinese were readily able to associate Islam with one of the ethnic groups understood to make up the plurality of their own society, yet in Japan there was historically neither a Hui population nor much knowledge of the Hui, and therefore, the initial understanding of $k a i k y \bar{o}^{6}$ was not associated as much with a tradition but more with an ethnic group. It was, however, associated with China.

The direct contacts that did exist between Muslims and Japanese prior to the nineteenth century, however, should not be overlooked, and in fact, more evidence of these contacts continues to emerge. During the Nara Period (710-794), Nara served as the eastern terminus of the Silk Road, as cultural products, artifacts, influences, and knowledge poured in from the Asian mainland - particularly China, but also from Korea, Central Asia, India, and Persia. In Nara, the Shōsōin has served as a storage facility for treasures collected during this era, and has collections of glassware, medicines, and musical instruments known today to have Middle Eastern origins (Enayat 1994, 99:

\footnotetext{
${ }^{5}$ The root of the term 'Hui' was, in fact, likely referencing the modern Uyghur people, who were in earlier times rendered as Hui (Gladney 2003, 453).

${ }^{6}$ Following a common trend in the Japanese language, in the postwar era kaikyo has gradually been replaced with the denizen-rooted Isuramu-kyō (イスラム教). The most significant impetus for this particular linguistic transition was the 1979 Islamic Revolution in Iran (Sakai 2010, 127).
} 
Miyata 2017, 120). In 2016, a wooden artifact discovered in the 1960s in Nara was analyzed with infrared imaging technology, revealing that a Persian was not only in Nara, but was hired as lecturer, likely of mathematics, in an educational institute for government ministers (Samuels 2016). Archeological pieces such as these have corroborated a theory that there was direct trade and inter-personal relations between Persians and Japan as early as 600AD. The Nara Period started a few decades after the Arab conquest of Persia, yet Islamization of Persia was gradual and only a minority of Persians were Muslims by the eighth century, so it is unclear if Persians in Nara were Muslims themselves, or for that matter, even familiar with the religion spreading in their homeland. It was not until the subsequent Heian Period (794-1192) when a broader (yet still limited) knowledge of Islam entered Japan via China (Sakai 2010, 126). Yet, it was still understood as part of China.

Japan's connection to the Silk Road declined in the Heian Period (794-1185) as relations with the Tang Dynasty (618-907) in China were cut off in the mid-ninth century. Relations with China (and Korea) did pick up during China’s Song Dynasty (960-1279), just as many Middle Eastern and Central Asian Muslims were migrating to China as traders, ${ }^{7}$ but sea trade routes across the Indian Ocean were gradually replacing the Silk Road. Relations were constrained once again on the mainland when the Mongols invaded China in 1268, founded the Yuan Dynasty, and then in 1274 and 1281 attempted, twice, to invade Japan. Relations would pick up some between China's Ming Dynasty ${ }^{8}$

\footnotetext{
7 These 'settlers' are significant roots for formulating the identity of the modern Hui people in China, although DNA evidence is mostly inconclusive.

${ }^{8} \mathrm{Lan} \mathrm{Yu}$, for example, was a fourteenth century Muslim Ming general who was known to be particularly fond of Japanese swords, having 10,000 in his possession (Fan 2016, 94).
} 
(1368-1644) and Japan's Muromachi Era (1336-1573), but were sporadic in the late fifteenth and sixteenth centuries as Japan was amid civil warfare. In 1592, and again in 1597, Japan attempted to invade Korea en route to invading China. This brought an influx of Chinese and Korean prisoners of war into Japan, who unwillingly brought with them cultural and technological knowledge, which may have included knowledge of Islam. Near the same time, Europeans began arriving from the south, Portuguese Jesuits proselytized Christianity in Japan, and a reorientation of the Japanese conceptualization of the outside world was taking place.

At the beginning of the seventeenth century, much had changed in Japan. The country was for the first time unified under a military dictator when Tokugawa Ieyasu attained power in the 1600 Battle of Sekigahara, and three years later he established a hereditary military government (a shogunate). Meanwhile, a new conduit of knowledge of Islam opened through a new channel: the Namban Trade. During this time, entrepôts were developing in Southeast Asian cities such as Thang-long in Vietnam, Ayutthaya in Siam, Aceh on Sumatra, Bantam and Mataram on Java, Makassar in the Celebes. The Japanese (and Chinese) were largely cut off from the vibrant maritime trade networks in Southeast Asia for centuries due to the threat from wakō piracy, but once the powerful daimyō, Toyotomi Hideyoshi, took measures to curb the piracy in the late sixteenth century, it opened up the East China Sea and South China Sea to more trade vessels. Upon assuming power in 1600, Tokugawa Ieyasu encouraged foreign trade as a way to increase revenue for the state. The shuinsen, or "red-seal ships," were Japanese trade ships approved by the Tokugawa authority in the early seventeenth century to trade in Southeast Asia ports, especially the Pattani Sultanate and Ayutthaya Kingdom in present- 
day southern Thailand, but also Java and the Maluku Islands in present-day Indonesia all with a significant Muslim presence among both locals and migrant traders - and undoubtedly came in contact with the Muslims during this time.

Between 1600 and 1635, over 350 shuinsen sailed to Southeast Asia. "Japanese merchants, warriors, [and] officials...for the first time frequently flowed toward Southeast Asia," and their presence "introduced not only economic exchange but also cultural and political interaction with local population and administration" (Liem 2011, 1). According to Frank, "[t]he Japanese also established a merchant colony at the regional entrepôt of Ayutthaya (near modern Bangkok) in Siam” (1998: 99), so large, he adds, "[b]etween 1604 and 1635...the Japanese controlled the trade of Siam" (1998: 106). Circumstantial evidence indicates that Japanese sailors on the shuinsen gained knowledge of an Islam beyond the Hui variant in China, but there are two reasons why such knowledge failed to return to Japan to shape discovery and identity via geocultural or geo-economic means. Firstly, a large number of crewmembers on the shuinsen were not Japanese; rather, they were hired Chinese, Portuguese, and Dutch crewmen. Secondly, because many of the Japanese who did join the crews were rōnin samurai or Japanese Christians escaping persecution, they chose to settle in Southeast Asia, and never returned to Japan. The Namban Trade might be more appropriately considered here a conduit of geo-economic foreign policy, and indeed it was, but in terms of impacting Japanese discovery and identity regarding Islam, it did very little for the above reasons. Moreover, it was short-lived; in 1632 the Japanese community in Ayutthaya was the victim of an attack and many were massacred, and three years later the shuinsen policy was abruptly stopped (Frank 1998, 99). Around the same time, Tokugawa became 
increasingly concerned with the spread of Christianity by Portuguese Jesuits in southern Japan, and banned the religion from Japan. Both of these factors led to Tokugawa's decision to end Japan's participation in the Namban Trade, and implement laws to close Japan off from foreign contact. Maybe knowledge of Islam beyond the Chinese variant was brought back to Japan during the Namban Trade, but if not, it was certainly introduced in the period that followed.

The end of the Namban Trade ushered in the Sakoku ("closed country") period which lasted until the arrival of American Commodore Matthew Perry in 1853. During this period, trade and interaction were limited to what was brought into Nagasaki Port by the Dutch and Chinese. In the early decades of the Sakoku period, Persian merchants, who were Muslims, are known to be among those who arrived in Nagasaki on Dutch and Chinese trade ships (Samuels 2016), but activities in the port were strictly regulated by Tokugawa authorities, thus limiting any momentous exchanges of religious knowledge (Sakai 2010, 127). Much of the learning of the outside world (beyond China) came through rangaku (Dutch learning). While rangaku was mostly Western knowledge in subjects such as astronomy, botany, medicine, and geography, it is doubtful rangaku included theology. This is because one of the key rationales behind the Sakoku policy was to prevent the spread of Christianity in Japan. The Portuguese were banned from sailing into Japanese ports, but among Western powers, only the Dutch were allowed precisely because they did not attempt to proselytize Christianity. Aware of this privilege allotted to them, Dutch teachers, and other foreigners engaged in the rangaku exchange of knowledge which may have included Muslims, were unlikely to bring up Christianity, Islam, or any other knowledge of religions. Nonetheless, rangaku is significant in setting 
a path in Japan for constructing a dominant epistemology based on the scientific revolution occurring in Europe. A deeper knowledge of Islam and stronger contacts with the non-Chinese Muslim world would not advance until after the 1854 'opening' of Japan.

Ironically, the modernization which occurred in Japan during the 1868 Meiji Restoration brought about a revival of Shinto as the state religion. This was evident in the term 'restoration' in lieu of 'revolution'; changes would coincide with a renewal of the spiritual source of the nation: the Emperor. "Indigenous religious tradition accompanied modernization and the growth of a modern nation" (Cho and Katzenstein 2011, 175). The theological underpinnings of the Meiji Restoration are, in fact, counter to understood processes of modernization, and therefore bear similarities to the late 1970s Islamic Revolution in Iran. Moreover, both events marked the overthrow of hereditary authoritarian regimes by a force undergirded with religious undertones of righteous governance, found in both Shinto and Shia Islam.

The Ottoman Empire was the first among Muslim-majority states to send a diplomatic mission to Japan, yet the event resulted in a bizarre tragedy which would serve as a catalyst in the development of Japanese-Muslim relations and identity to come. In 1890, the delegation reached Tokyo and met with the Japanese Prime Minister and the Meiji Emperor (Penn 2007, 35). During the trip, the diplomatic success of the Ottoman mission was overshadowed by an acute outbreak of cholera among the sailors. The Japanese responded by quarantining the Ottomans and their ship, the Ertuğrul, on a minor island until the epidemic was declared eradicated. Rather than risk another outbreak, however, the Ottoman delegation determined to return to Istanbul without 
continuing the diplomatic visit, and the Ertuğrul departed southbound along the coast of Japan. Before reaching the coast of Kobe, the ship was destroyed by a violent typhoon and sank, resulting in the death of over 500 men (Worringer 2014, 88). Locals cared for the 69 survivors until the Japanese government arranged for a ship to return them to Istanbul.

The Japanese were impressed that the Ottomans had traveled so far, despite the challenges of illnesses and misfortune (Penn 2007, 43). The Ottomans were impressed by the Japanese hospitality and humanitarian gestures (Penn 2007, 43). They were also impressed by the Japanese Imperial Navy, which was able to retrieve submerged equipment, recover nearly 300 bodies, and return survivors to Istanbul (Worringer 2014, 88-89). The Japanese came to understand the Ottoman Empire not as Europe, as was believed by the Japanese elites at the time, but indeed, as part of Asia (Penn 2007, 44). If Japanese and Ottomans could share sympathy, sorrow, and mutual admiration through tragedy, they must share the same Asian worldview. Thus, the conception of panAsianism in Japan commenced, spanning from the Ottoman Empire in the west to the Japanese Empire in the east.

At the turn of the twentieth century, emerging in the Muslim world was the idea that Japan presented a model for modernization without Westernization. Meanwhile, in Japan a notion of a pan-Asia society free of Western imperialism was simultaneously materializing. The term "Eastern modernity" was being used by Muslims and Japanese alike (Worringer 2007a, 1). In the 1904-05 Russo-Japanese War, for the first time in modern warfare an Asian state defeated a European state. Russia's defeat exacerbated the spiraling unpopularity of the Czar and ultimately led to his deposition and the end of the 
Empire. Muslims from Istanbul to Jakarta, but especially in Central Asia and the Caucasus Region, observed these events with great interest. As Worringer describes, Japan's success resulted in it becoming "larger than life for observers on both sides of the East-West binary" (2014: 54). It "became an exoticized nation, a country of mythical capabilities, threatening for Western powers intent upon preserving their colonies, and a model to be emulated for Asians who imagined their own self-directed destinies" (Worringer 2014, 54). The question was asked: could Japan "be the 'Savior of Islam' against Western imperialism and colonialism" (Esenbel 2011,1)?

Worringer argues that Meiji Japan provided "a creative and dynamic intermediary step in the Middle East's progression toward formulating an 'alternative universalism' to that imposed upon it by the West" (2014: 26). The timing of Japan's modernization was crucial given the concurrent imperialism in the Middle East and philosophy of postEnlightenment European thought (Worringer 2014, 39). For many Muslim and nonMuslim Asians alike, amid this milieu Japan had attained the "highest state of moral evolution possible, according to a set of standards defining national behavior that were predicated upon Western intellectual thought" (Worringer 2014, 251). Ottoman writers argued that "the Japanese had combined their indigenous moral values with imitation of Western technical improvements, and thereby achieved their current power and status" (Nezir Akmeşe 2007, 66). This was emulated through the rallying expression in Meiji Era Japan: wakon yōsai (和魂洋才), “Japanese spirit and Western technique.” Russia was the Ottomans' enemy state, and “Japan was a perfect role model for the decaying Ottoman Empire" (Nezir Akmeşe 2007, 66). Paradoxically, within the declining Ottoman Empire, Japan served as a model for Arab populations who juxtaposed the modernized and 
powerful Japanese empire with the backwards and declining Ottoman Empire (Worringer 2007b, 92). This put the Ottomans in a dilemma. Sultans within the Empire especially clung to the Japanese model, as it was viewed as a way to modernize and maintain their custodial role as Sultan, based on the role of the Japanese Emperor (Worringer 2007b, 94).

Concerns over 'Yellow Peril' in the West were transformed in the Muslim world into an equally sensationalized idea of an Asian liberator. While undoubtedly a common Asian identity was formed in reflection of Western identity, how did Muslims and Japanese reconcile their starkly different religious practices, customs, and cultural milieu? After the Russo-Japanese War, Muslim students flocked to Japan to study Western sciences without risking exposure to Westernized values (Eich 2007, 123). Many among them had additionally set out to proselytize Islam in Japan. Indeed, if Japan were to become a Muslim state, it would have tremendous geopolitical implications for Eurasia. Consider that pre-World War I Japan was already occupying the Korean Peninsula and Taiwan, and the process of Japanification had commenced in these colonies culturally, linguistically, and religiously, Spkyman's rimlands would have manifested as an almost geographically contiguous Asian civilization under Islam.

From proselytizing Muslim students, the Japanese had found a way to learn about Islam and usurp it into an emerging pan-Asian narrative. In the 40-year span between the Russo-Japanese War and the end of World War II, there was a flurry of Japanese academic and political interest on Islam. In 1920, Sakamoto Kenichi provided the first 
Japanese translation of the Qur'an (Krämer 2014, 621-22). ${ }^{9}$ In the 1930s, the first three mosques in Japan were erected in Nagoya, Kobe, and Tokyo. Interestingly the funding for the Tokyo mosque was provided by the Japanese government as well as prominent companies such as Mitsubishi (Krämer 2014, 619). In 1933, nationalists in Japan were already speaking of "making Japan the protector of Islam” (Benda 1958, 103), and by 1938 the Greater Japan Muslim League (Dai Nihon Kaikyō Kyōkai) was established with government and military sponsorship as a research institute directly subordinate to the Cabinet Planning Office (Krämer 2014, 619). By 1944, Tokyo hosted one of the largest library collections of European-language books on Islam, particularly outside of the West (Aydin 2011, 137-38). Undoubtedly, the government and military interests in Islam were tied to the vision of a Greater East Asian Co-Prosperity Sphere, as well as subduing the Muslim populations already under Japanese rule by the 1940s in China and Southeast Asia.

Interest in Islam among many in Japan had indeed an ulterior motive, relating to Japan's vision of a pan-Asian society under its control, and while many Japanese Muslims were deemed "bogus Muslims" after the War, there were also individuals who either converted to Islam altogether, or had a genuine interest in incorporating elements of the religion into the Japanese social épistème (Misawa 2011, 120). Krämer argues that

\footnotetext{
${ }^{9}$ Interestingly, Sakamoto presents Allah as kami (神), the gods (plural) present originally in Shinto (literally, shin-tō is written with the same character, 神道, meaning “the way of the gods"). Protestants in Japan had already assumed kami to mean God in singular, and this was the accepted translation of the Christian God in Japanese (Krämer 2014, 622). To the Japanese, however, kami is a plural term, and thus the Christian 'God' and Islamic 'Allah' could be accepted by complementing the existing multiplicity of Shinto kami. Sakamoto's successors, perhaps cognizant of this gap in understanding of singular versus plural, maintained the title 'Allah' in subsequent translations of the Qur'an (Krämer 2014, 622). Comparatively, translations of Christian texts into Japanese today still maintain kami as the singular Christian God.
} 
for many Japanese, "pan-Asianism was a reality that was part of their biography" (2014: 620-21). In 1904, Tanaka Ippei traveled to China and was impressed by the way the Hui peoples integrated both Islam and Confucianism into their daily practices. This "Islamic Confucianism" ${ }^{\prime 10}$ inspired Tanaka to syncretize Shinto and Islam. After his 1924 pilgrimage to Mecca, Tanaka wrote on his idea of the syncretism: Islam "contains a truth equal to our truth of the way of kami" (1925: 2). He remarked elsewhere, "compared with Christianity, Islam bears more resemblance to Confucianism ${ }^{11}$ and our old Shintoism. So, the religion of Islam must syncretize with the Japanese people in the revival movement of Asia" (1928: 2).

The occupation of the Dutch East Indies provides a historical case of rare overlap of the Japanese Empire onto the Ummah. By the late 1930s, the Japanese were spreading propaganda in the Dutch East Indies that the Emperor would eventually convert to the Prophet's religion, and an "Emperor-Caliph of Greater Japan" would soon emerge (Benda 1958, 105). While Indonesians responded with mixed reactions, even more complex were the Indonesian responses to the Japanese replacement of Dutch authority in 1942. The Japanese had a plan to demonstrate to the Indonesians their commitment to Islam, dictating in messages that they shared the same "resentment against Christian rule," yet in practice the Japanese occupiers displayed less understanding of Islam, adat law, and religious jurisdiction in Indonesia than the Dutch (Benda 1958, 109). It has been alleged that Japanese military officials even once considered 'moving' Mecca to

\footnotetext{
${ }^{10}$ Kaiju in Japanese, Huiru in Chinese (回儒).

${ }^{11}$ Okakura Kakuzo also wrote that "Islam itself may be described as Confucianism on horseback, sword in hand" (1904: 2).
} 
Singapore so that the center of Islam would be within Japanese control (Lewis and Wigen 1997, 72).

The Japanese were quick to rectify relations with Muslims in Indonesia and, in fact, pandered to local Muslim interests in order to maintain a degree of legitimacy, yet there were key religious aspects to administration which led to inevitable conflicts. The Japanese insistence that their Emperor was divine clashed directly with the Islamic beliefs. While the Japanese attempted to explain the similarities between Shinto and Islam, Indonesians were skeptical. Benda sums up the incongruity:

Shinto and Islam do share certain similarities, since both are all-embracing creeds in which little or no distinction is made between the realms of religion and politics. But it was because of this very similarity that they were bound to clash as soon as the adherents of one of these universalistic systems endeavored to superimpose their beliefs and practices on those of the other (Benda 1958, 123).

It was in this occupation of a vast Muslim population that the Japanese began to realize the limitations of their narratives of pan-Asianism, as it conflicted with simultaneous nationalist narratives of Japanese authority over Asia. Japanese military leaders were forced to remain silent as Indonesian Muslim leaders criticized the occupation. This granted a certain degree of immunity for the Muslim communities, which were able to rapidly network independence movements and institutions which were prepared to rebel when the Dutch would return in late 1945. This Japanese yielding to Muslim leaders during its occupation ironically led the populace to view many Muslim leaders as collaborators with the Japanese. Partially because of this tainted image of Muslim leaders as collaborators, the independence movement ultimately rejected the idea of an Islamic state in favor of a secular one (Benda 1958, 187). 
In China, the experience of Muslim populations under Japanese occupation garnered the greatest sympathy in the Muslim world against Japan, and remains a significant stain on Japan's image for Muslims, especially in postwar China. Among other Chinese, the Hui suffered atrocities by the Japanese Army which included executions, the destruction of mosques and cemeteries, and enslavement (Lei 2010/2012, 139). While most cases appear to have been indiscriminate atrocities that occurred among all populations, certain deliberate humiliations occurred against Hui Muslims. Lei notes cases where Hui were forced to slaughter hogs on request from Japanese Army soldiers (2010/2012: 141). Seeking assistance, Hui sent messages to Muslims in the Middle East. They attracted the attention of many Muslims, who disseminated their message further, and garnered the support of Muslims the world over to oppose Japanese aggression in China, to side with the Allies in the war, and reject their message of 'liberators of Asia' as propaganda.

The end of World War II brought about the end of Japanese occupation of Muslim populations. Parts of the Ummah occupied by Japan - the Dutch East Indies, Malaya, and North Borneo would soon thereafter gain their independence from the European empires. The transformative role that Japan played among those in Muslim countries during the post-War decolonization era was significant, yet the merging of Islam with Japanese religions and the ideals of pan-Asianism were put to rest. During the Allied occupation of Japan, many of the Islam institutes were disbanded, as they had developed into panAsianist and anti-West organizations during the War. In the early twentieth century, Japan had indirectly inspired Islam via its victory over 'the West' in the Russo-Japanese 
War. ${ }^{12}$ Yet, it was the atomic bombing of Japan by 'the West' which evolved into the anti-West narratives that emerged in the postwar Muslim world (Miyata 2013, 95). To many Muslims, Japan was Orientalized (Sakai 2010, 143). The bombings of Hiroshima and Nagasaki illustrated a lack of humanity by the West, and Oriental people were the victims of this. During and after the Iranian Revolution, Ruhollah Khomeini made frequent reference to the American bombing of Hiroshima and Nagasaki (Miyata 2013, 95-96). Since the World Trade Center bombing in 1993, Ramzi Yousef and Osama bin Laden also made frequent references to Hiroshima and Nagasaki (Miyata 2013,96). Yet, this is not limited to the speech acts of extremists; it has served as a key exemplar of the dehumanization of Orientals by the West, used by those who carry an anti-West sentiment throughout the Muslim world (Miyata 2013, 110).

Much of the geocultural relationship between Islam and Japan can be traced to inter-personal relations today. It is estimated there are 130,000 Muslims living in Japan ${ }^{13}$ - mostly foreign nationals from Muslim countries, and not Japanese converts (Tanada 2013, 31). Proportionately, this is much lower than in the West or other developed countries. It is estimated that roughly 80 percent of Japanese who marry Muslims convert to Islam, and number only 10,000 (usually Japanese women marrying Muslim men) (Asahi Globe 2014: Tanada 2013, 32: Abedin 2010). Japanese Islamic scholar and practicing Muslim, Hassan Ko Nakata estimated in 2010 that there were less than 100 "genuine converts" among Japanese, where marriage to a Muslim was not a factor in the

\footnotetext{
${ }^{12}$ As an Orthodox Christian-state with the Czar family's kinship to European royalty, the Russian Empire was considered undoubtedly part of 'the West' at the time.

${ }^{13}$ Because the Japanese census does not record religious affiliation, estimates are based on the population of foreign nationals by country, divided by the percentage of Muslims in the given country.
} 
decision to convert (Abedin 2010). The overwhelmingly largest Muslim population in Japan in 2017 are Indonesians (40,800), followed by Pakistanis (14,300), Filipinos $(13,800)$, Chinese $(12,000)$ (including approximately 1,000 Uyghurs), and Bangladeshis $(11,700)$ (e-Stat 2018: Vandenbrink 2012) (see Table 2.1). A sizable minority of these Muslims in Japan, particularly among the Pakistanis and Filipinos, are married to Japanese (Fukuda 2015, 38: Tanada 2013, 36-37).

One program which has potential to significantly increase the interpersonal contacts between Japanese and Muslims is a high-profile program started in 2008 to allow Indonesian and Filipino nurses and caregivers to train for qualifications to work in Japan. The program was high-profile because it was believed to be the start of relaxing the immigration policy to allow in foreign workers to offset the population decline in Japan. Moreover, these Indonesians and Filipinos would specifically fill the void in nursing and hospice workers needed for the rapidly growing elderly population in Japan. Estimates show the nursing industry will be short between 380,000 and 500,000 trained nurses by 2025 (Emont 2017). Additionally, it is estimated that there will be 7.8 million elderly citizens in need of nursing care, which is nearly a doubling of the number in the matter of two decades (Kingston 2014, 193)! It has sparked much media attention in Japan, as well as attention from academics and politicians as well. If the nurses and caregivers can pass a Japanese qualification exam by the end of their temporary stay in training, their stay can be extended with the potential for permanent residency and even apply for citizenship. In reality, however, once the program was initiated, the passing rate for qualifications has been extremely low with only a few dozen passing each year. As Kingston argues, "[t]he basic problem is that this program is designed to fail and offers 
little immediate relief to the existing acute shortages of nurses and caregivers in Japan and also no long-term solution" (2014: 194). While high-profile, it represents a small segment of the Indonesian and Filipino population in Japan, but it certainly ranks high in the public consciousness among Japanese of these peoples relocating to their country. Among Muslim-majority countries, the largest Japanese-national populations are found in Southeast Asia: in Malaysia $(67,019)$ and Indonesia $(44,864)$ (MOFA 2017b). The numbers drop considerably, however, in South Asia and the Middle East. While there is a very large presence of Japanese nationals residing in China $(306,678)$, statistics provided by MOFA are unable to illustrate the amount of interaction between the Japanese nationals and the 20 million Muslim Chinese. The same is true of the sizable number of Japanese nationals in India and the Philippines. Nonetheless, it can be assumed that in all three states personal interactions are present. In stark contrast, there are estimated less than 11,000 Japanese-nationals residing in all of the Middle East region (MOFA 2017b). While the inter-personal relations between Japanese nationals and Muslims of Southeast and East Asia are strong, the inter-personal relations with Muslims in South Asia, Central Asia, and especially the Middle East are extremely limited today. There is, however, a significant geo-economic relationship which is discussed in the following section.

\section{Geo-economics}

The geo-economic relationship between Japan and Islam has been, at least, in the background of inter-civilizational relations consistently since the first encounters. A high energy consuming nation-state with negligible fossil fuel resources, Japan is heavily dependent on the resources available in Muslim states. As this chapter shows, the geo- 
economics in this relationship are intricately connected to the geopolitics and national security. An acute example of this was seen in 1940, when the Japanese need for crude oil was the catalyst for its expansion into the Ummah, inadvertently leading to American involvement in World War II. When the Nazis invaded France, the Japanese responded by laying claim to French Indochina in 1940. The U.S., in turn, responded by embargoing scrap metal and crude oil exports to Japan. At the time, roughly four-fifths of Japan's crude oil came from U.S. exports. The Japanese estimated their only means to survival was to seize the oil resources in the Dutch East Indies.

In the immediate postwar decades, geo-economics was almost the only facet of relations between Japan and Muslim Asia, as interpersonal and diplomatic relations were constrained by the U.S.-dominated postwar order in Asia. Meanwhile, Japanese consumption steadily increased and fossil fuel imports shifted from the U.S. to Muslim states in Southeast Asia and the Middle East. While much literature on the 1973 oil crisis focuses on the impact it had on security and economic policy in the West, little mention is made of the impact on Japan. In fact, Japan was adversely affected by the 1973 oil shock more than any other consumer market in the world (Licklider 1988, 207). For Japan, the oil crisis resulted in panic, surging prices, and a sudden scarcity of manufactured goods depend on petroleum, starting with toilet paper, then detergent, sugar, and kerosene (Sugiyama 2008, 4).

By early 1974, production had increased and the embargo was lifted, but the oil crisis left its mark on Japan, and the world economy. An economic recession and soaring inflation rates hit Western economies and Japan. In 1974, the inflation rate in Japan exceeded 20 percent in what was called 'kyōran bukka,' or the 'price frenzy,' and the 
economy shrank for the first time in the postwar era (Hosaka 2013/2014, 66). This brought on an existential threat that harkened back to wartime. "The disruption instantaneously transported them back to the bitter postwar years of deprivation and shortages. Suddenly their economic achievements of the 1950s and 1960s seemed very precarious" (Yergin 1992, 616). The evidence that energy security is existential security was laid bare in Japan: "[t]he confidence that had been built up with strong economic growth was suddenly shattered; all of the old fears about vulnerability rushed back" (Yergin 1992, 616).

Ironically, however, through the lasting impact of the 1973 oil crisis on Japan's domestic economy, fossil fuel dependency was curbed with the advancements of the nuclear power industry. Furthermore, automobile makers had already advanced in fuel efficiency research and development (R\&D), so that by the time the second oil crisis occurred during the 1979 Islamic Revolution in Iran, Japan had a buffer to the global impact. With the West struggling to recover from the 1979 oil crisis, Japan was able to take advantage of its production of cheap, fuel-efficient automobiles for export, and therefore, become a stronger economic power globally in the 1980s. This geo-economic interaction confirmed Japanese identity as a nation able to overcome the hardships and threats presented in 1973, especially in comparison to the U.S. and other Western economies.

Today, Japan remains vastly reliant upon crude oil and natural gas imports from the Middle East as well as other Muslim states, and for much of the late twentieth century, it served practically as the single tether which kept Islam within the purview of Japanese foreign policymaking. Nearly 90 percent of Japan's crude oil imports come 
through the Straits of Malacca, from the Middle East or Africa (Burrett 2014, 164). As discussed in the previous chapter, access to the shipping lanes through the South China Sea and the Straits of Malacca is essential for Japanese fossil fuel imports, and most significant are petroleum imports from states on the Persian Gulf - notably Saudi Arabia and U.A.E. The risks associated with transporting petroleum resource imports are immense, and will not be alleviated in the foreseeable future. For natural gas, the reliance is less severe yet still problematic. Twenty-nine percent of Japan's natural gas imports comes through the Strait of Hormuz, with 18 percent wrapped up in long-term LNG contracts with Qatar (Hirose 2015). Considering that other significant sources of natural gas are in Southeast Asian Muslim states Malaysia, Brunei, and Indonesia, and also subnational regions in Nigeria and Russia, it is plausible that two-thirds of Japan's natural gas comes from Muslim-majority regions and countries.

Similarly, Muslim states collectively make up a significant market for Japanese exports, but this is a much more recent phenomenon. Nasr makes the point that an "upwardly mobile class consumes Islam as much as practicing it, demanding the same sorts of life-enhancing goods and services as middle classes everywhere" (2009: 14). He adds, "A booming economic sector around the region is catering to this exploding demand, and these rising Islamic consumers $[\mathrm{sic}]$ comprise as much as a sixth of humanity, spread across a vast expanse from Morocco to Malaysia” (2009: 14-15). As previously mentioned, Indonesia and Malaysia are two of Japan's most significant markets. Beyond these two, there is the potential for a stronger relationship as a larger middle-class emerges in Muslim states. 
The geo-economics of relations between Islam and Japan are intrinsically intertwined with the geopolitics in such a way it is difficult to detach analysis of one without detaching the other. The following section picks up on the political elements of the aforementioned economic relations. Underlying both the geo-economics and geopolitics for Japan's relations with Islam is the element of security. As illustrated, fossil fuel dependency has drawn Japan to Muslim states since the early twentieth century, and continues to do so. After the 1973 oil crisis, energy security was incorporated into national security, as illustrated in Tokyo's 1980 comprehensive security policy. At different layers, however, security is a key variable in this relationship in the post-9/11 era, and the Security Alliance with the U.S. has resulted in self-reflection on obligatory commitments to operations in Muslim states versus self-defined values in diplomacy.

\section{Geopolitics}

Japan's identity is in many ways defined by its security alliance with the U.S.

Meanwhile, based on the export of high-technology and automobiles, Japan has the third largest economy in the world, yet must rely on imports of fossil fuel resources to meet almost all of its consumption demand. Indeed, the domestic demand for energy resources is the leading (but not sole) impetus for Japan's relations with Muslim states in Asia today, shaping Japan's ontological security and, thus, identity. Access to markets is increasingly important, but still secondary. Geopolitical variables, however, are increasingly relevant in Japan's foreign policy with Muslim states. This section focuses on the geopolitical interactions between Japan and Islam. 
Between the postwar occupation and the 1973 oil crisis, Japan's relations with Islam at all layers were confined, in large part due to the strong reliance on the U.S. for security, trade, and even Anglo-American supermajors for access to Persian Gulf and Southeast Asian fossil fuels. In this period, Japan's primary means of indicating an independently developed postwar policy towards Muslim Asia was within the UN framework. While serving on the Security Council, Japan was among the very few industrialized states that voted in favor of the General Assembly Resolution 2628 of 1970, which promoted the "respect for the rights of Palestinians" (Yoshitsu 1984, 1). Yet, the Japanese leadership was "so quiet about its position that it seems to have reaped no rewards from it in the Arab world" (Yoshitsu 1984, 1).

In October 1973, Organization of Arab Petroleum Exporting Countries (OAPEC) governments took action to pressure consumer economies to support the Arab position in the Arab-Israeli War. Crude oil exports to the U.S. and the Netherlands were embargoed on account of their military support for Israel, and in addition, global production was slashed. By carrying out the second measure, OAPEC's intention was for Japan and other European consumer economies to pressure the U.S. to disengage with Israel (Licklider 1988, 206). In November, the Saudi and Kuwaiti governments declared Japan a "nonfriendly" state (Licklider 1988, 214). After several ad hoc negotiations with compromises on both sides and Japan taking measures to distance itself from the U.S. and Israel, Japan was reclassified as a 'friendly' state and continued to move in a pro-Arab direction within the institution of the UN in the years subsequent to the crisis. In 1981, Japan became the first state in the developed world to have talks with the Palestine Liberation Organization at the prime ministerial level (Licklider 1988, 215). In 1982, 
Stein noted in her research that Japan was the "most pro-Arab industrial country" in the world (57-59).

While generally assumed to be diplomatically weak in the initial decades after World War II, close examination reveals Japan displayed a strikingly different position toward Muslim states than did the West. In 1959, Japanese politician Utsunomiya Tokuma expressed his support for the National Liberation Front (FLN) in Algeria, and even established an FLN Far East diplomatic mission in Tokyo (Miyata 2013, 104). Utsunomiya twice traveled to Algeria during the war, and while not officially representing the Japanese government, “[o]nly a short time after losing World War II to France, a Japanese political figure displayed a spirit which strengthened the consciousness of Japan to the Algerians" (Miyata 2013, 104). While Japanese support was in the consciousness of Algerians fighting for independence in the 1950s, the relationship changed considerably in January 2013 when 17 Japanese hostages were among those caught up in the Amenas hostage crisis, and eventually 10 of the 17 would be killed. The militants were extremists linked to al-Qaeda and certainly not representative of the Algerian government (who eventually sent special forces to attempt to free the hostages), yet the event has put a damper on what was a limited, yet cordial relationship between Japan and Algeria, and also resulted in a trend of a deteriorating image of Islam among the Japanese public. ${ }^{14}$

\footnotetext{
${ }^{14}$ In early 2013, leading Islam scholar from Japan, Osamu Miyata was poised to publish his new book entitled Why Do Muslims Love Japan? When the Amenas hostage crisis broke out, the publishing company requested Miyata to postpone publishing, and retitle his book Why Do Muslims Respect Japan? (Sankei 2013).
} 
Japan's relationship with Pakistan has been difficult as well, yet it illustrates an internal conflict of values and priorities and a key case of reactionary relations. When Bangladesh declared its independence from Pakistan in 1971, Japan was the first developed state to recognize its independence (Miyata 2013, 110). Subsequently, the lowpoint in Pakistani-Japanese relations was in 1998 when Pakistan conducted the Chagai-I underground nuclear tests. Of all states, Japan imposed the harshest sanctions, recalled its Ambassador from Pakistan, and suspended all of its foreign aid (the most of any foreign government) - a clear illustration of the values-based diplomatic position Japan took with regard to nuclear proliferation (Pattanaik 2008, 886). This decision was motivated by both geopolitics and geoculture, insofar as nuclear nonproliferation is a key element in Japan's postwar identity. Under pressure from Washington, and based on geopolitical interests, Tokyo resumed diplomatic relations with, and foreign aid to Pakistan after the September 11 attacks. Today, Japan is again a significant source of foreign aid for Pakistan, disbursing $\$ 6.7$ billion from 2008 to 2012. Meanwhile, Japan's strengthening security cooperation with India as well as the sale of amphibious aircraft to India has caused a new rift in relations with Pakistan (Mahr 2014).

Japan's commitment to nuclear non-proliferation in its diplomacy creates a clash between geoculture and geopolitics, inciting debate in the early twenty-first century for two reasons. Firstly, Japan has developed nuclear reprocessing plants which can produce plutonium and a considerable amount of highly enriched uranium (Horner 2012: NTI 2014). Tokyo's stockpiles accumulated since 2000 could be converted into military use within a matter of weeks to months (Cirincione 2007, 105). Being only a 'screwdriver's turn' from producing a nuclear weapon, a non-nuclear values approach to foreign policy 
is palpably hypocritical. ${ }^{15}$ As long as Japan maintains such capability, it surrenders its ability to champion such a cause globally, despite being the only state to experience the horrors of nuclear weapons in warfare. Secondly, energy security (geo-economics) has clearly taken priority with regard to Japan's position on Iran's nuclear energy program. Tokyo maintained distance from the West regarding stringent sanctions imposed on Iran due to its nuclear energy program in the first decade of the twenty-first century.

In the first Persian Gulf War of 1991, Tokyo was for the first time openly pressured by Washington to dispatch Japan Self-Defense Forces (SDF) for overseas military operations (Midford 2011, 68). This opened a chapter of tension between Washington, and specifically, the Japanese public, who have distinctly different ways to "view the utility of strategically offensive military force" (Midford 2011, 68). The idea of dispatching the SDF generated suspicion among the Japanese public and "reminded many Japanese of their state's reputation for being incapable of controlling a military, especially when deployed overseas" (Midford 2011, 68). After the 9/11 attacks on the U.S., "the Japanese public's distinctive world outlook was challenged as perhaps never before" (Midford 2011, 110). An initial concern that a similar terrorist attack could occur in Japan was expressed among the public and political leaders, however public resistance to joining the U.S. to "combating terrorism" overseas endured (Midford 2011, 111). Nonetheless, Prime Minister Koizumi Junichirō was quick to dispatch the SDF ships to the Arabian Sea to provide rear-area logistical support for the U.S. military operations against al-Qaeda and the Taliban in Afghanistan. While the majority of the public

\footnotetext{
${ }^{15}$ In fact, attaining the materials and technology for a nuclear weapon, but refusing to develop it is even known as 'the Japan option.'
} 
supported "cooperation" with the U.S., less than half approved of Koizumi's dispatch of the SDF to the Arabian Sea (Midford 2011, 115).

From the beginning, the Japanese public, however, was overwhelmingly skeptical of joining the U.S. in an attack on Iraq. The government remained uninvolved during the early stages of the Iraq War and the 2004 fall of Baghdad, but in mid-April Koizumi's cabinet began speaking of "fear of abandonment" if they did not support the American operation (Midford 2011, 131). Without deliberation in the National Diet, at the G8 summit Koizumi pledged SDF support for the U.S. military operations in Iraq (Miyata $2005,265)$. In order to compromise domestic opposition ${ }^{16}$ and personal concerns for the alliance with the U.S., Koizumi agreed to dispatch the SDF, but limit their operations to noncombat zones (Midford 2011, 132).

Hosoya Yuichi describes Japan's current policy in Asia as two layered policies (2014: 154). The first policy is the East Asian Community (EAC), which is an 'interestoriented' form of diplomacy, and was articulated by Koizumi in 2002. The plan encourages Asian states to "act together and advance together," emphasizing cooperation with countries sharing the values of freedom and democracy (Hosoya 2014, 150). As the name suggests, however, it is limited to East Asia. The second is the Arc of Freedom and Prosperity, discussed in detail in Chapter 1 and essential for this project. The Arc is much broader in geographical scope and vision (while the EAC could be argued, has more depth). While there is overlap in the visions, there are also key omissions: the EAC includes China as a cornerstone; the Arc does not. Both of these policies signal a new

\footnotetext{
${ }^{16}$ Interestingly, Koizumi's LDP-coalition party, New Komeito, which is a conservative party backed by the Sōka Gakkai sect of Buddhism, initially opposed the SDF dispatch to Iraq, but approved after adding several conditions to the law, and received harsh criticism from its pacifist base (Métraux 2007, 162).
} 
brand of pan-Asianism based upon 'Asian democratic values' and economic development. Here, geo-culture and geo-economics dovetail. Japan's 'Asia policy' is often construed as a means to counter the emergence of China as a regional hegemon. If this is indeed the case, this is where geopolitics comes in, and the need for closer ties between Japan and Muslim countries is particularly acute. At this point, the dormant preWar geoculture explorations and narratives could potentially be revived as the means to link the geopolitical relationship between Japan and the Muslim world.

\section{Conclusion}

There are five primary factors which weigh heavily on Tokyo's foreign policy toward Muslim Asia. These are: first, the aforementioned fossil fuel dependency, which is interpreted as an issue of national security, beyond the realms of geo-economics; next is affiliation with the West, and obligations that come with alliance with the U.S., often referred to as 'gaiatsu' (外圧), or “outside pressure," in Japanese; third is a post-War domestic non-interventionist tendency, particularly with regard to combat zones; fourth is Japan's own values exerted through diplomacy, namely its own distinguished version of democracy and free markets, institutionalism, and strong (if not, hypocritical) nonnuclear values; last is the export markets and FDI potential in Muslim states. While economic, these tie closely with political decisions in Japan, as big business has an intricate relationship with the political class. All these factors weigh on the decisions made in Tokyo regarding foreign policy with Muslim states.

Japan's conceptualizations of Islam and its role in the world order are taking on a new trajectory. After the beheadings of Japanese nationals in January 2015 by ISIS, Japanese scholars of Islam such as Miyata Osamu agree that "the Iraq War had a 
tremendous influence on [extremists] viewing Japan as an enemy" (2015: 13). This

opinion has picked up dramatically in domestic politics. Miyata continues,

[a]mong Middle East Muslims there is a favorable opinion of Japan, but since the Iraq War an image is emerging of a Japan which does whatever the U.S. tells it to do. Rather [than working with the West], a better approach for Japan would be to coordinate with Gulf states such as Saudi Arabia and Kuwait with regard to ISIS (2015: 13).

This advocates for not only distancing from the West, but in fact, linking with Muslim states in Western Asia.

Significant third-parties have made a tremendous impact on the intercivilizational relations between Japan and Islam. Termed reactionary relations in this chapter, other actors such as Russia, Hindu India, China, and the West have interacted with, or even served as the impetuses for interaction between Islam and Japan. This will continue to be the case, particularly as the emergence of China will shake up the interactions among all major actors within the Eurasian regional complex, including Russia and the U.S. This dynamic of competing visions by the regional powers in Asia is the central theme of the following chapter. How does Japan situate itself, and its own vision among the others? The Arc is the clearest expression of Japan's version of a vision for Asia yet.

In the last decade, Japan has lost its place as the largest economy in Asia to China, its population has been in decline, and incremental steps towards remilitarization are taking place. These issues are discussed in more detail later, but in brief, they indeed explain a Japan that is redefining itself, reassessing its position in world order, and in particular, its influence, role, and identity in Asia. As Keiko Sakai poignantly puts it, "[t]he transformation of the Japanese perception of Islam and the Middle East reflects the 
transformation of the perception of Japan's own position in Asia” (2010: 143). If Japan continues on a path to seek a pan-Asian identity with a role distinct from the emerging giants, China and India, it will need to deepen relations with the Muslim world.

With extremists making headlines in Japan since 2001, there is the risk that the impression of Islam will become tainted, resulting in mistrust and aversion among Japanese. The January 2015 beheadings by ISIS have deeply contributed to this trajectory. Miyata argues, "Japanese view of Muslims is not as cold as in the West. The beheading incident will undoubtedly trigger a prejudice, but there is no sense of threat that Muslims in Japan will commit terrorist acts" (2015: 13). If Japan can maintain a relationship with Islam based on its own interpretations - separate from the influences of, or obligations to other major actors, there is potential for transformative relations to develop which would be significant to all of Asia. 
Figure 2.1: Reactionary Relations between Islam and Japan

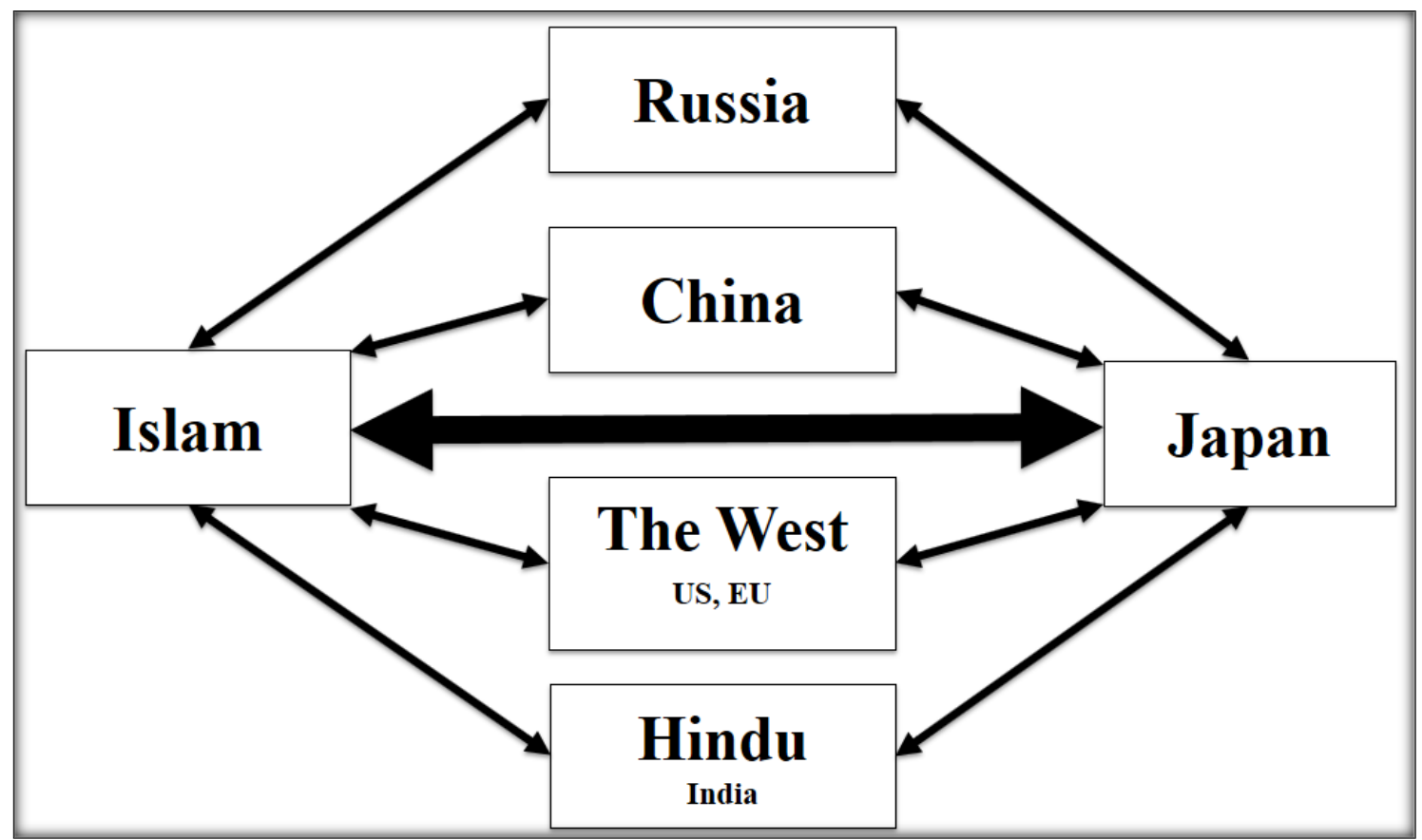


Map 2.1: Islamic Ummah and Japanese Archipelago in Asia

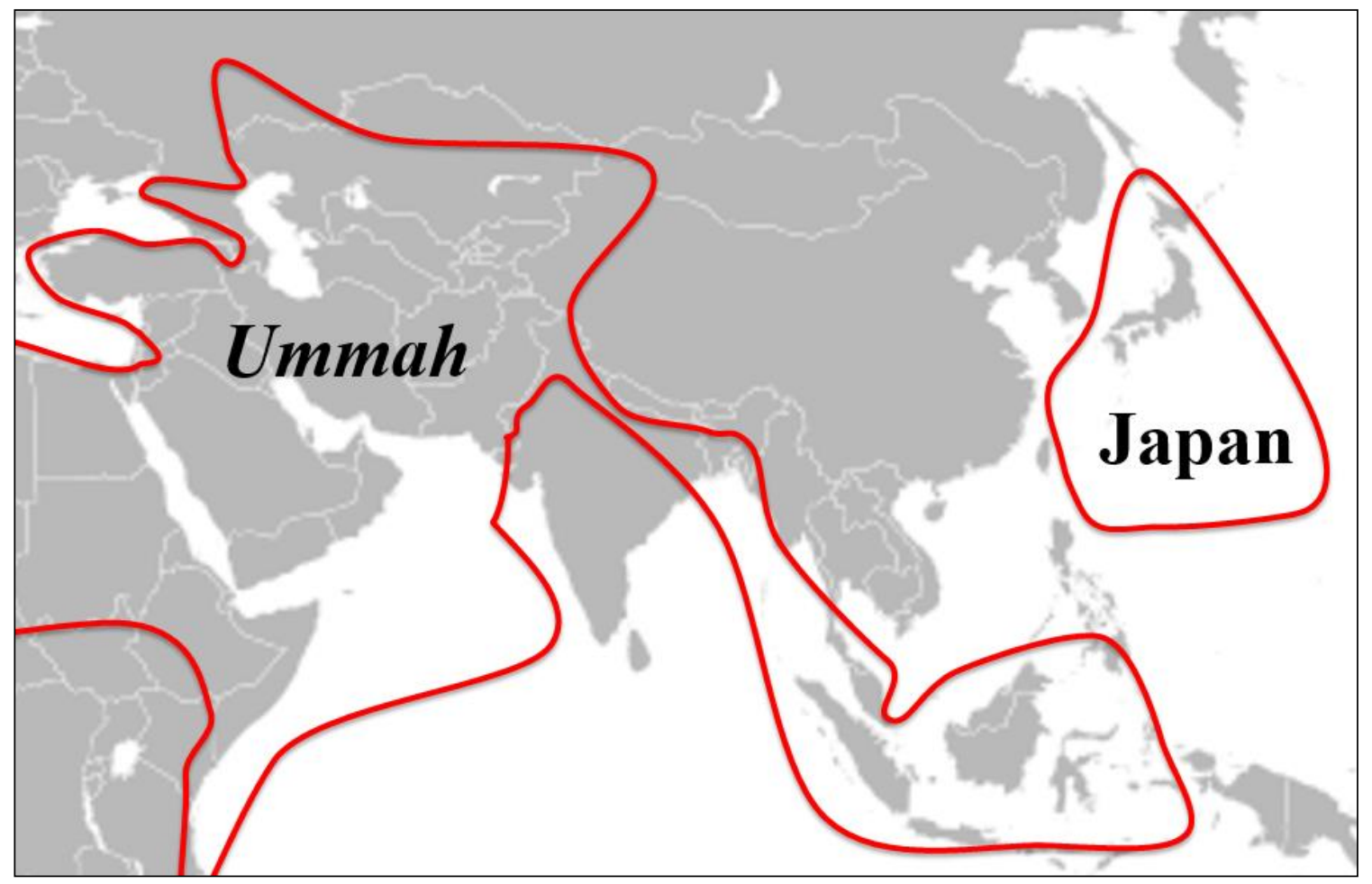

Map by author. 
Table 2.1: Population Estimate of Muslims in Japan by Nationality, 2017

\begin{tabular}{ll} 
1. Indonesia & $40,800(31.4 \%)$ \\
2. Pakistan & $14,300(11.0 \%)$ \\
3. Philippines & $13,800(10.6 \%)$ \\
4. China & $12,000(9.2 \%)$ \\
5. Bangladesh & $11,700(9.0 \%)$ \\
6. Japan & $10,000(7.7 \%)$ \\
7. Malaysia & $5,600(4.3 \%)$ \\
8. Turkey & $5,100(3.9 \%)$ \\
9. India & $4,300(3.3 \%)$ \\
10. Iran & $4,000(3.1 \%)$ \\
TOTAL & $130,000(100 \%)$ \\
\hline
\end{tabular}

Source: Adapted using data from e-Stat (2018). 


\section{CHAPTER III}

\section{INTERNATIONAL AND DOMESTIC CONTEXT}

Japan's proclamation of the Arc of Freedom and Posperity in 2006, and the ongoing references to values-based diplomacy occur in international and domestic contexts which shape why, when, and how this proclamation took place. Japan's political elites are implored to consider shifts in the balance of power in Asia in the early twenty-first century, and how they must react to these and maximize the benefits of its position. Moreover, Japan has a vision for Asia, but it must consider how this vision competes and complements visions by other great powers in Asia. The first part of this chapter explores these competing visions for Asia among great powers. The second part then examines the domestic political actors and processes that led to the announcements of a new valuesbased diplomacy. Of particular interest is the elite bureaucracy, and how the new pillar to foreign policy passed through their competiting interests. With an understanding of why, when, and how the announcement took place, this project has a better foundation to proceed to the strategy.

\section{Competing Visions for Asia}

Japan is undoubtedly not alone with a vision for Asia, and when Japan's vision is put into policy, strategy, and definitive action, it contends with visions, policies, strategies, and actions by great powers on the continent. This section lays out the backdrop for visions of Asia in the twenty-first century. It examines the structural dynamics that Japan's vision of a values-based Arc has to contend with, but it also clarifies how this vision interacts with other visions by great powers in terms of how they compete in both an ideational and material competition, and also where they may complement each other. The great powers 
that have their own visions for Asia which interact most unmistakably with Japan's own vision are China, Russia, and the U.S. Each of these powers has its own pronounced framework which encapsulates its vision: for China, it is the One Belt, One Road Initiative (BRI); for Russia, it is the neo-Eurasianist school of thought; for the U.S., it is the Pivot to Asia. Together with Japan's values-based diplomacy, initially labeled the Arc of Freedom and Prosperity by Asō Tarō in 2006, four frameworks for Asia provide windows into each power's vision for the continent. BRI is more clearly enunciated as a development strategy; neo-Eurasianism is more akin to a prevailing purview held my many in the Kremlin; consistency on the Pivot to Asia is questionable in the transition from an Obama to a Trump administration. Nonetheless, juxtaposing these four elucidates visions. How can Japan compete with these? What are its viable advantages and disadvantages?

This section proceeds by briefly outlining the Chinese, Russian, and American visions for Asia, respectively. The classical geopolitical framework for analysis is applied since all four visions deal with ideational intepretations of the integral qualities of a space, and power politics on this space. The chapter then juxtaposes each vision, making comparisons to Japan's values-based Arc. Through this juxtaposition, the dynamics of twenty-first century Asia are better understood, the ideational competition among great powers in Asia is better understood, and Tokyo's maneuverability within this milieu for strategy is clarified.

\section{China: One Belt, One Road}

Like the Westphalian system of nation-states, and the Islamic Ummah, China has its own classical vision of world order: the suzerainty - an order of concentric circles, 
with the Emperor of China at the center of civilization. China's order was both "hierarchical and theoretically universal" (Kissinger 2014, x). Moving out next is China proper, then the tributary states - smaller kingdoms which recognized the imperial authority and in return for paying tribute, gained security. Outside of this system were the barbarians - those who did not recognize the Emperor's universal authority over "All Under Heaven" (Kissinger 2014, x).

This is consistent with China's worldview during the empire and today, even though China's worldview has gone through substantial transformations in the twentieth century. While the emperor is no longer part of the system, Beijing is at the center politically, and the concentric circles remain, exemplified in policy initiatives such as the Silk Road Economic Belt, and the first island chain and second island chain military doctrine - a two-step Monroe Doctrine of the Western Pacific. Beijing, and, to an extent, Han China, is now at the center of the system; next is 'greater China,' which includes the minority populations mostly found in peripheral provinces, special administrative regions, and autonomous regions - all peoples and territories within the modern nationstate. Beijing's struggles in these regions are labeled by Kaplan as "Irritable Border Syndrome"; "Xinjiang and Tibet are the two principal areas within the Chinese state whose inhabitants have resisted the pull of Chinese civilization. This makes them imperial properties of Beijing, in a way" (2010: 22). Then, the modern version of tributary states - those bandwagoning with the rising China, and thus, those adhering to this new (revived) order. This varies, but it is where BRI comes into play. China is attempting to (re)construct an order in Asia with itself at the center based on its long-held model of a Chinese suzerainty. 
How is China reviving its suzerain system in an Asia of Westphalian nation-states with concerns over development, poverty, energy resources, nuclear proliferation, and religious violence? The impetus to BRI came in 2013, during the first few months of Xi Jinping's presidency. In September 2013, Xi first mentioned a 'Silk Road Economic Belt' while on visit in Kazakhstan for the Shanghai Cooperation Organization (SCO) summit. The idea was to develop transportation infrastructure projects which would facilitate an "economic belt" that would link China to Central Asia, Russia, and on to Iran, Turkey, and ultimately Germany and the Netherlands (Ferdinand 2016, 949-50). The one road component was elicited a month later in the October 2013 Asia Pacific Economic Cooperation (APEC) summit in Indonesia: a maritime linkage of southeast China with Southeast Asia, South Asia, the Middle East, and by great extension, Africa and Europe. Both ideas were notably announced in Muslim Asian countries. By early 2015, the two were merged into a broader framework: the name, One Belt, One Road, comes from the Chinese shorthand, yìdài yīlù (一帯一路), that allows for discussion the two initiatives in tandem (Summers 2015, 1630).

The framework is broad and has tremendous implications for Asia and China. Ferdinand points out it "potentially involves over 60 countries with a combined population of over 4 billion people, whose markets currently account for about one-third of global GDP" (2016: 950). BRI, the Chinese government explains:

aims to promote the connectivity of Asian, European and African continents and their adjacent seas, establish and strengthen partnerships among the countries along the Bel and Road, set up all-dimensional, multitiered and composite connectivity networks, and realize diversified, independent, balanced and sustainable development in these countries (State Council 2015). 
$\mathrm{Xi}$ Jinping was quoted as saying "China welcomes all countries along the routes and in Asia, as well as our friends and partners around the world to take an active part in these endeavors" (Xinhua 2015). The language used by Chinese political leadership as well as official documents presents a policy with objectives and geographic scope of BRI that is so broad that it is immeasurable and boundless, which makes finding tangibility challenging.

Actions have already been taken. China played a key role in setting up the Asian Infrastructure Investment Bank (AIIB) - a financial institution which directly competes with the Japan-U.S.-led Asian Development Bank (ADB). AIIB was created with the specific intention so Beijing could circumvent constraints of the existing financial order provided by the Japanese- and American-controlled ADB. China has committed $\$ 50$ billion for the AIIB, and coupled with $\$ 40$ billion for the Silk Road Economic Belt and \$25 billion for the Maritime Silk Road, it is showing a strong financial commitment to modifying order in Asia. Shambaugh points out that "even during the Cold War, the United States and the Soviet Union did not spend anywhere near as much as China is spending today" (2015).

BRI and all that has come with it has at its heart a deeply rooted Sinocentric view of Asia. Chinese discuss the period from 1839 to 1949 as the 'Century of Humiliation.' China was an empire, and at the center of a universal suzerainty, yet powers that came from outside the suzerain system, Europeans, Americans, and Japanese, destroyed that order. A country that viewed itself at the center of universal order was weakened, occupied, and plundered by barbarians. Beijing's vision of Asia is much like it was 
thousands of years ago - with Beijing at the center. BRI is a restoration of that universal order held for millennia.

\section{Russia: Neo-Eurasianism}

While not as longstanding as China's Sinocentric conceptualization of order in Asia, Russia's neo-Eurasianism also has deep roots that have persisted in Russian thought. Like pan-Latin Americanism, Europeanism, or pan-Asianism, it is a geographic ideology - a Weltanschauung, or more precisely a 'Eurasienschauung.' Naturally, as a transcontinental state with territories in both Europe and Asia greater than any other European or Asian state, Russia is at the center of this conceptualization. Russia is not in the middle between Europe and Asia; rather, it is at the center of Eurasia. "Eurasianism thus conflates the center and the middle" (Laruelle 2008, 1).

Russian Eurasianist thought originated in the late nineteenth century with a movement among Slavophiles to reject European identity (Clover 1999, 9). A more detailed manifestation of the concept would not emerge until the 1920s. At this time, Soviets gave up on an imminent worldwide proletariat revolution subsequent to the Bolshevik Revolution, and turned their discourses to Soviet distinctiveness - a discourse that appealed to many in the Communist Party as well as dissidents in exile as well (Laruelle 2008, 18). The Eurasianists tied Russian people to the Turkic-speaking peoples of Central Asia, who, they claimed, originated in ancient Persia, and followed a more collectivist political and economic model which contrasted with European individualism (Foreign Affairs 2014). Unlike the Soviet communists, the Eurasianists emphasized the positive role Orthodox Christianity, Islam, and Buddhism played in Eurasia, and in Russia, specifically. 
The writings of Lev Gumilev and Aleksander Andreevich Prokhanov contributed to a revival of Eurasianism in the 1980s, deemed 'neo-Eurasianism,' which calls for Russia "to fulfill the crucial mission of connecting - and pacifying" both the East and West (Merati 2017, 32). Japanese writer Sawabe Yūji describes Eurasian thought: “Russia is considered a 'hyper-nation-state,' consisting not only of Slavic peoples, but also Turkic, Iranian, Mongol, and several other peoples, and it is destined to become an inevitable empire" (2017: 91). The ideology was quickly picked up among the political elites in the early 1990s and came to dominate Russia's Ministry of Foreign Affairs (Bassin 2016, 218). Today, it is seen in the legislature, the Defense Ministry, and even the "military elite have also caught Eurasian fever" (Clover 1999, 9). Former Prime Minister Yevgeni Primakov put several neo-Eurasianist ideas into policy and strategy, although he never commented on neo-Eurasianist thought, himself (Clover 1999, 9). Prominent advocates today include veteran nationalist politician and LDPR leader Vladimir Zhirinovski, and political scientist and author Aleksandr Dugin.

The degree to which neo-Eurasianist thought impacts Russian foreign policy is difficult to ascertain. Certainly, elements of neo-Eurasianism appear in statements made by Putin. In 2001, Putin stated, "Russia has always felt herself to be a Eurasian country. Never have we forgotten that the greatest part of Russian territory is in Asia" (Laruelle 2008, 7). Neo-Eurasianists applauded when in 2005 Putin acknowledged that the collapse of the Soviet Union was the greatest geopolitical catastrophe of the twentieth century. Putin has also publicly praised the work of Gumilev:

His scholarly works are a brilliant contribution not only to thinking about history but also to the assertion of the centuries-old community and interrelation between the peoples who inhabit the vast expanses of Eurasia, from the Baltics and the 
Carpathians to the Pacific Ocean. The instructive potential of Eurasianism is especially significant today (quoted from Laruelle 2008, 10).

Undoubtedly, actions in Crimea and eastern Ukraine illustrate the significance of geopolitical calculations in the Kremlin's policy and strategy. What is the Kremlin doing, however, to viably expand its geopolitical sphere of influence across Eurasia?

Neo-Eurasianism is not inevitably a hard-lined outlook involving Russian ethnonationalism and geopolitical expansionism. The school of thought has come in various incarnations from writers contradicting one another, particularly regarding Russia's role, and it can be interpreted in softer forms. Some formulate it with a rightwing, Orthodox Christian worldview (Laruelle 2008: Wiederkehr 2007), while others have observed ties developing between this rightwing movement in Russia and political Islam in Russia (Merati 2017, 110). Consistent in all forms of neo-Eurasianism is the desire "to build a larger geopolitical axis of allies - such as Germany, Iran, and Japan - to resist the American influences" (Tsygankov 2013, 64). Mainstream political elites are more attentive to this basic principle of neo-Eurasianism than to the more radical ancillary points. Within this principle, however, lie the policies that can be seen over the last two decades in the form of Eurasian integration.

Neo-Eurasianism presents a two-tier conceptualization of Eurasia: there are the former Soviet republics which must be reintegrated first, then a broader Eurasia inclusive of Turkey, Iran, China, and Japan. If Russia is content with a Eurasia where Moscow exerts political influence over the former Soviet republics, yet Asia beyond the near abroad works in tandem with Moscow to ensure a multipolar order in Asia, then this vision of Asia is more palpable than Moscow exerting political influence across the vast 
continent. In greater Asia, Russia must cooperate with other powers, namely China, to ensure the multipolar order it envisages. Yet, as Kotkin remarks, "China has openly and vigorously been building its own Greater Eurasia, from the South China Sea through inner Asia to Europe, at Russia's expense and with its cooperation” (2016: 2). This contestation inevitably takes on more intensity in Central Asia because it is both within the Kremlin's 'near abroad' and the first line of China's Silk Road outside of its own borders. Russia and China can agree to keep the U.S. out of greater Asia, but Central Asia is a key overlapping zone of influence for Russia and China.

\section{The United States: Pivot to Asia}

In late 2011, the Obama Administration announced a 'Pivot to Asia' - a shift of its grade strategy toward Asia. ${ }^{1}$ It was soon followed up with plans to increase the marine presence in Australia, a slight increase in the number of U.S. troops in South Korea, the basing of more military hardware in Singapore, and enhancing the defense alignment with the Philippines. The U.S. also increased discussions of defense cooperation with Indonesia, Vietnam, Cambodia, and Malaysia, and has increased the number of joint military exercises with Japan and India (Resnik 2015, 13). In economics, the TransPacific Partnership (TPP) would deepen interdependence among the U.S. and states across the Asian-Pacific region.

\footnotetext{
${ }^{1}$ After 2011, Obama administration officials chose to rebrand the new grand strategy as a 'realignment' rather than 'pivot.' Some have suggested that 'pivot' was "both inaccurate and misleading," but in actuality, it is more accurate and more truthful of the underlying vision that drove the announcement $(\mathrm{Wu}$ Xinbo 2016, 849). 'Realignment' is evasive of directions and intentions. 'Pivot' is more enlightening. It provides an honest window into the underlying strategy, and the attempt to rebrand it as a "realignment' was too little too late.
} 
There are a number of issues with the Pivot strategy, many of which were unforeseen at the time. A pivot motion necessitates shifting the direction faced, while maintaining one's point on the ground. This is consistent with the U.S. having maintained its focus on the greater Middle East for the better part of four decades. After the oil shocks of 1973 and 1979 and the Iranian hostage crisis, the 1980 Carter Doctrine was a de facto 'pivot to the Middle East.' Subsequent military actions in Libya and Lebanon, and full-scale wars in Iraq, Afghanistan, and Iraq again solidified and justified this pivot, as did the threats from religious terrorism originating from this region. So, from Washington's perspective, this is a pivot from its east to its west - a pivot from an Atlantic view of Asia to a Pacific view. In fact, part of the 2011 Pivot announcements included the plan to shift navy distribution from 50/50 capabilities in the Atlantic and Pacific to 60 percent in the Pacific and 40 percent in the Atlantic by 2020 (Resnik 2015, $13)$.

The first problem that emerges with any 'pivot' is turning one's head from what had garnered attention before. Did the Middle East lose its imperativeness, or did Asia simply become more pressing? Both are plausible factors in Washington's thinking. Americans elected Obama largely on account of war fatigue in the Middle East, and he committed to ending combat operations in Iraq. Moreover, and even more relevant to the long-term strategic goals of the Carter Doctrine, the shale energy revolution has resulted in the U.S. becoming less dependent on oil exports from the Persian Gulf. American allies like Japan remain dependent, but how long are Americans willing to secure the supply of oil from the Persian Gulf, especially as this energy export is increasingly making its way to China? Conflict remains in the Middle East, as do the ongoing 
perception of threats from Islamic terrorism, but Middle East war fatigue has settled deep into Americans, and without seeing a direct benefit to securing energy supplies from the Persian Gulf, Washington is becoming less concerned. In fact, one thing 2008 candidate Obama and 2016 candidate Trump share is an indirect desire to keep the U.S. military out of conflicts in the Middle East. A pivot always results in one's previous focal point now becoming either a blind spot or in the periphery.

The second problem with the Pivot is that there is unmistakably a panda in the room. Beijing cannot help but sense that Washington's pivot is a grand strategy precisely aimed at taking advantage of China's geostrategic insecurities. To Beijing, the pivot is "a constraint on China's growing power in the region" (Li and Shoon 2015, 44). This may have been entirely the point. To be sure, the Obama administration continued to reiterate that the pivot was "a key initiative to ensure sustainable growth and development for countries in the Asia Pacific region" (Li and Shoon 2015, 44). Yet, the subsequent policy announcements under the purview of the pivot were by and large military-based. Moreover, the progress being made is among states along China's periphery, many of which have longstanding territorial disputes or ongoing animosity with China, such as Japan, the Philippines, Vietnam, and India. If, indeed, the Pivot were for the purposes of supporting sustainable economic growth, economic cooperation between Washington and Beijing would be crucial, and, in fact, the point of departure for the grand strategy. Moreover, Washington would put itself in the diplomatic position to intermediate a reconciliation between China and Japan, and between China and India. Yet, outside of defense cooperation initiatives, and in the economic realm, the only evidence of a Pivot was the failed TPP. 


\section{Competing and Complementing}

Among the three aforementioned visions for Asia, as well as Tokyo's valuesbased Arc, the geographic scopes of the visions vary as much as the ideational contents of each. Russia's neo-Eurasianism has a two-tiered approach to Asia (although, for their intents and purposes, Eurasia). First, is Russia's near abroad: the idea is to (re)integrate the former Soviet republics, not as a resuscitation of the Soviet Union, per se, but as a regional bloc not dissimilar to the EU. Second, is to integrate a broader Eurasia, inclusive of partners such as Iran, Syria, and Serbia. China is included insomuch as objectives are aligned, and those objectives tend to coalesce in a multipolarity to counter American influence. Beijing and Moscow have a developing symbiotic trade relationship based on the import of Russia's vast resources into China. This was evident in the 30-year, $\$ 400$ billion natural gas deal starting in 2018. With European natural gas consumers reluctant to sustain their reliance on Russian gas, Russia and China both see a newfound benefit in economic integration.

Beijing's vision of Asia is long embedded in its strategic thinking - long before the U.S. or even the Russian Empire was formed. The suzerain system is the Sinocentric system, and it permeates BRI. What is to be the modern 'tributary state,' however, is much broader than it has been ever before. It is inclusive of 'new partners' as far afield as Kenya and Hungary. What is Beijing's Asia? Overtly, it is whoever wants to be on board with BRI; it is an initiative to develop and prosper together, but it is conspicuously focused on infrastructure and development, and thus, conspicuously focused on the less developed economies of Asia (and Africa) for its investment projects. It is, in a sense, China championing itself as a leader of the developing world, and claiming to have the 
deep pockets to finance a mutually coinciding rise out of poverty. It is worth noting that the Chinese-led AIIB, which can be interpreted as Beijing's counter to ADB dominated by Tokyo and Washington, is open to Japanese and American membership. While the UK, Germany, Canada, Russia, South Korea, and Australia have all joined, Japan and the U.S. remain noticeably indifferent to AIIB. Mogi argues that Washington and Tokyo are both "suspecting China's bubble economy will collapse in the future," and thus the ABD remains the more pragmatic option for both investors and borrowers (2017: 84). China overwhelmingly holds the largest number of shares, and the bank is located in Beijing. It is telling of who is more accommodating of the Sinocentric order in Asia, and who is not.

It would appear the U.S. cannot consider a geostrategic pivot without considering the defense sector as the primary actor in implementation. Among Russia's neoEurasianism, China's BRI, and the U.S.'s Pivot, the American vision is the most obfuscating. Pivot to Asia means what Asia? After all, the pre-Pivot focus was the Middle East, yet Iraq, Syria, Iran, and Afghanistan are Asia, and this is understood in neoEurasianism, BRI, and even Tokyo's Arc. It is a re-Oriented vision for Asia. Moscow has been conceptualizing Asia for a very long time. Beijing has been conceptualizing it much longer. The American vision is confused, and not really sure what are its objectives, or how to achieve them. The Pivot is interpreting Asia as the traditional allies along the Indo-Pacific regions, including Japan, South Korea, the Philippines, and Australia, and nascent partners such as India, Indonesia, and Vietnam. It is mindful of China, if not being the central purpose for the Pivot, but it is understood as part of Asia, nonetheless. Thus, there is a good Asia and a bad Asia embedded in the vision of the Pivot. 
Tokyo's Arc complements and competes with all three visions. It most obviously complements the American Pivot. In fact, with a relatively sizable American military force on its territory and a long-standing security alliance, Japan is a linchpin to the Pivot. Moreover, the rise of China's military is Tokyo's greatest state-level security threat, and indeed, what keeps it close to the U.S. Insomuch as the Arc and the Pivot are to counter a Sinocentric Asia, the visions are aligned. Washington will continue to nudge Tokyo to remilitarize, seeing it as a proxy for its own interests in Asia, but as appealing as 'equal partners' sounds to Tokyo, remilitarization is very unpopular domestically. If the Pivot is indeed focused on sustained economic growth in Asia, Tokyo's Arc is also nicely aligned with this objective as well. If we take the Pivot at face value, both visions seek economic development and prosperity across Asia, and both countries believe they have an important role in this vision. From both countries' perspectives, they see that over the last three decades the two of them have provided overwhelmingly the most official development assistance (ODA) across Asia, they commit the most capital for ADB, and their companies also provide by far the most FDI into China, as well as considerable FDI across Asia for the last three decades. Interestingly, moreover, there is no sense of competition between the two for their own roles within their own visions of Asia; rather, their visions of Asia are complementary and assume mutual participation.

Tokyo's Arc is not necessarily in absolute competition with Beijing's BRI, either. While the ADB and the AIIB may be in competition, it is important to note the China retains a sizable share in $\mathrm{ADB}$, as the third largest investor and the largest borrower. If it were a direct Sino-Japanese competition, Beijing would have pulled out from ADB investments long ago. Yet, symbolically, the competition of the two banks is revealing of 
Beijing and Tokyo's visions for Asia. In the article "Two Asias: AIIB v ADB," Malcolm Cook argues that they "exemplify the very different understandings of Asia held in Beijing and Tokyo and the very different views of Japan's place within Asia expressed by the ADB and China's place in Asia expressed by the AIIB" (2015). He adds the geopolitical framing of the two:

modern Japan, as an archipelagic power on the North Pacific periphery of the Eurasian landmass, has a North-South maritime understanding of Asia. China, as a vast land power with an inland capital, has an East-West continental understanding of Asia...Post-war Japan's Pacific nature and close relationship with the US have led Japan to pay particular heed to the United States' interest and place in Asia (2015).

With ADB and AIIB, compatibilities of Beijing and Tokyo's visions for Asia are also evident. Both the Arc and BRI seek out development across a wide swath of the Asian continent, inclusive of Southeast Asia, South Asia, Central Asia, and the Middle East. In Central Asia, for example, it has been observed that Tokyo and Beijing can serve roles which are symbiotic. Badykova argues that "China helps generating cash from oil and gas, while Japan helps [Central Asians] invest it in projects that can secure an industrial base for Central Asian economies" (2016). Through BRI, China provides flexible financial means to attain development; through the Arc, Japan provides the rules framework which can maximize the societal gains from these projects. Moreover, Tokyo's activity in the region "fosters regionalism and industrialization, while China promotes diversification of Central Asian exports and globalization" (2016).

It is in both China's and Japan's interest to see development and stability in Asia, yet where they differ is the Sinocentric order in Asia. Moreover, Tokyo's values-based Arc did not include China, and Tokyo had differentiated itself by making the Arc a 
values-based pillar of foreign policy which is based on democratization. Whether and how Tokyo has pressed this value is discussed further in Chapter 7, but its inclusion in the policy outline, and a consistent reiteration of this value makes Tokyo's Arc not only distinct from Beijing's BRI, but also exclusive of China, as a non-democratic state. China's growing predominance in Asia and global economic competition has made the carrot and stick approach of democratization-measures-for-development-aid unfashionable in Asia as well as elsewhere in the twenty-first century. If Tokyo is not serious about encouraging democratization measures by using the purse, at least the language of democratization embedded in the Arc is enough to make it a vision of Asia exclusive of China.

It would be shortsighted to think, however, that Japan is unequivocally determined to create its vision of Asia exclusive of China. China remains one of Japan's top destinations for ODA, and Japanese corporations' top destination for FDI; moreover, Sino-Japanese trade relations are the deepest of any two Asian states. Aside from historical animosity, territorial disputes, and general distrust, the two countries are deeply interconnected with each other's economies. The previous chapter discusses the EAC, elucidated by Prime Minister Koizumi Junichirō four years prior to the Arc. Like the Arc, Koizumi's EAC emphasized cooperation with countries sharing the values of democracy, but he made it a point to include China in this vision. While there are similarities between EAC and the Arc, and indeed the EAC can be seen as a nebulous precursor to the Arc, the geographic visions are considerably different. The EAC was specifically delineated as the integration of Japan, South Korea, the Association of Southeast Asian Nations (ASEAN) members, Australia, and New Zealand, but also China. It used the ASEAN+3 framework 
for its geographical scope. In his EAC speech, Koizumi made clear, "I would like to highly praise the active role China is willing to play in regional cooperation. With its wealth of human resources and huge economic potential, China will surely make an enormous contribution to regional development" (2002). The Arc spans like a belt, from Southeast Asia to Turkey and Eastern Europe, but it is not inclusive of China.

Koizumi's vision of Asia inclusive of China differs from his successors and fellow LDP elites, who have tended to emphasize Tokyo's alliance with Washington over cooperation with Beijing. The main opposition party at the time, the Democratic Party of Japan (DPJ), showed much more overt overtures towards Beijing. DPJ Prime Minister Hatoyama Yukio, who only served less than a year, was clear about his intention to pivot Tokyo's foreign policy from the U.S. alliances to strengthening its partnership with Beijing. Since stepping down in June 2010 due to failed policy initiatives and a high unpopularity rating, Hatoyama has continued to advocate for strengthening relations with Beijing and even acquiescing to a Sinocentric order in Asia. $^{2}$

Hatoyama may not represent the broad interests of the Japanese populace, the political elites, or even his own party, but his approach of acquiescing to Sinocentric order in Asia does represent a long-persevering counterapproach to China in Japan. While broadly speaking, China is perceived as the greatest state-level threat to Japan and favorability polls show a deep distrust between the Chinese and Japanese, there is a strand of thought that persists in Japan from pre-modern times that hitching itself to

\footnotetext{
${ }^{2}$ Since leaving office, Hatoyama has issued an apology for Japanese war crimes in Nanjing, recommended Tokyo recognize the existence of a territorial dispute over the Senkaku/Daioyu Islands, and to the chagrin of many of his compatriots, he sits on the international advisory committee for the AIIB. It has been pointed out that "[b]y appointing a former Japanese prime minister as an advisor to the AIIB, China may be attempting to weaken the collaboration between Japan and the United States" (Japan Times 2016).
} 
China is ultimately in Japan's best interests; "the Japanese, in distant history, have gone through periods where they deferred to the Chinese, and it is possible they will one day do so again, especially if they perceive China as a rising state and their nation as a declining one" (Chang 2009). Currently, this is a view held mostly among those on the political left, such as Hatoyama, but it can easily change on account of signals of durability of Washington's commitment to Japan and the region writ large. It is often noted in Japanese modern history, "[i]f there is one lesson above all others that Japan learned from the twentieth century, it was that alliance with the global superpower Great Britain in the first two decades of that century, and the US for the last five offered the best assurance of stability and prosperity” (McCormack 2007, 55). Indeed, such a realist approach to statecraft could eventually dictate that between Washington and Beijing, the latter is possibly interpreted as more committed to stability in Asia.

Moreover, the latter is more economically interconnected throughout the region than the former. It is on Washington to prove that acquiescence to Sinocentric order in Asia is not in Tokyo's best interest.

Aleksandr Dugin and his works are well-known in Russia, and a discussion of neo-Eurasianism would be remiss without mention of his thought and influence on this doctrine. The direct influence Dugin has on the Kremlin is unclear, but the proliferation of his thought through lectures, books, and television appearances, and his role as advisor to members of the State Duma, the United Russia Party, unofficial advisor to Putin, and the military indicate that his ideas must permeate Russian doctrine to a significant degree (Laruelle 2008, 107-08). Dugin bases his philosophy of geopolitics on Mackinder's 
heartland thesis, and places Russia at the "pivot" of world order (Dugin 2007: Dugin 2013).

It is in Dugin's work where neo-Eurasianism does directly relate to Japan. Dugan advocates that Russia seek out strategic alliances with key powers along its periphery. In Europe, it is Germany with which Russia must ally; in the Muslim world, it is Iran; and in East Asia, it is Japan, to which he credits its early twentieth century pan-Asianist ideology (Laruelle 2008, 117). Thus, Dugan advocates for a quadruple alliance of RussiaGermany-Japan-Iran to dominate the Eurasian space, and defend against American intervention. Moreover, there is a hierarchy in this alliance as Dugan theorizes Russia as the global superpower, and Germany, Japan, and Iran are regional allies needed to support Russia in this hierarchy. ${ }^{3}$ To this end, Dugan has proposed the Kremlin return the Southern Kurile Islands to Japan and Kaliningrad to Germany in exchange for them deepening an alliance with Russia and severing ties with the United States (Laruelle 2008, 241).

With regard to China, Dugin's neo-Eurasianist vision is at odds with Moscow's gradual alignment with Beijing. He views Russia's sphere of influence not constrained to the borders of the former Soviet Union, but rather, inclusive of Manchuria, Xinjiang, Tibet, and Mongolia (both the republic, and China's autonomous region). This is consistent with Sawabe's thesis, that neo-Eurasianism, in general, represents an easterly shift for Russia, to balance with China (2017: 88). Dugan makes clear he considers China

\footnotetext{
${ }^{3}$ At other times, however, he has omitted Iran from this alliance he envisages, calling for a restoration of "the mythical triangle between Germany, Russia, and Japan” (Laruelle 2008, 142).
} 
the primary state-level threat to Russia's interests in Asia, along with the U.S. in the Americas, the UK in Europe, and Turkey in the Muslim world (1997: 247).

To this end, indeed, the Kuril's are key to a possible coalescing of neoEurasianism and Tokyo's Arc. Dugan's thought is not to be confused with Kremlin policy, but his approach to Japan regarding the Kuriles is a viable option that it would appear Putin has considered. More palatable to Putin would be a deal on the Kurile Islands dispute in exchange for Tokyo weakening its security alliance with Washington, or, at least, removal of American troops from Japanese soil. Russo-Japanese cooperation is certainly plausible, and there is undoubtedly room for deepening cooperation. Both visions share an emphasis on the post-socialist spaces. Despite the ongoing island dispute, Japan was the first G7 member state to invite Putin for a bilateral summit after the Crimean crisis. While Tokyo did join with Washington and other Western allies in condemning Moscow's actions, and also joined in the sanctions on Russia, domestically, there has been intense debate in Japan whether intense condemnation against Moscow over the Crimean Peninsula could be turned around in negotiations over a solution to the Kuril Islands dispute. In any case, the Kremlin has shown some interest in settling the territorial dispute with Japan, which is not characteristic of Russia when considering territorial disputes with Ukraine and Georgia, for instance.

Both Moscow and Tokyo have Beijing in mind; both are seeking leverage in the chance that relations with a rising China sour, and neither is comfortable being at best a junior partner with Beijing, but at worst a bandwagoning 'tributary' state to the Sinocentric order of Asia. Furthermore, Russia is looking for the inroad to weaken the U.S.-Japan alliance, and Japan is looking for an insurance policy, in the case the U.S. 
decides the Pivot was Obama's plan, and it like TPP, under Trump is dead. While not a pressing geopolitical issue on either side, the island dispute is complex and is often wrapped up in nationalism on both sides. Nevertheless, Moscow and Tokyo are continuing a slow-dance entente, in which exogenous factors in the shape of China and the U.S. are bringing them closer together.

This analysis reveals maneuverability in the international milieu. Visions of Asia are conceptualized and interact with other visions in both the ideations and material forms. This relates to the concept introduced in the previous chapter, reactionary relations, and it also illustrates how reactionary relations can take place even within conceptualization and policy, when nothing material has been carried out in terms of strategy. Indeed, reactionary relations can even happen just in the realm of thoughts and words put out into the international system. Tokyo reacts to notions and concepts expressed in Washington, Moscow, and Beijing, and vise versa. The following section turns in the opposite direction, by looking inward to reveal domestic political factors which shape how Japan approaches the international milieu through its foreign policymaking structure.

\section{Domestic Political Factors to Values Diplomacy}

The Arc was announced by Foreign Minister Asō Tarō in November 2006 while speaking at JIIA, Japan's largest and most influential thinktank founded by Asō's grandfather and preeminent postwar prime minister, Yoshida Shigeru. The prime minister at the time was Abe Shinzō. Both Abe and Asō were out of office within a year, however, and did not have extensive opportunity to carry out the new approach until December 2012, when Abe was re-elected Prime Minister, he appointed Asō to be his Deputy Prime Minister 
and Minister of Finance. When Asō announced the Arc and Japan's new values baseddiplomacy in 2006, Japan's economy was double the size of China's economy, its population had just peaked, and for the first time since data has been made public, China's military budget had just surpassed Japan's Self-Defense Force budget a year before. Also, just weeks prior to the announcement, North Korea successfully detonated its first nuclear device. To explain the action, it is prudent to examine the option of no action versus action. No action, however, amounts to not codifying existing foreign policy practices into overt language. Asō points out in his initial speech on the Arc, "this new axis for our diplomacy... is really nothing new for Japan at all. It is in fact nothing more than giving a name to the diplomatic achievements that Japan has built up...as well as giving it a new positioning within our overall diplomacy" (2006b). Thus, no action means continuation of foreign policy practices without the labeling of it as values-based diplomacy.

This announcement established consistency between existing practices and declarations of foreign policy. The choice was to retain Japan's engagement activities across Asia, yet keep them in in the backdrop as they had been, or intentionally highlight them, making all observers, both international and domestic, cognizant of its meanings and intentions. Tokyo chose to maximize its benefits from practices on the ground by proclaiming it. So, how did this decision come about?

The Iron Triangle

From a cursory glance, Japan's domestic political structure appears to be a case of plus ça change: first, LDP is in power - just as it has been almost continuously since 1955; second, major corporations still have substantial clout in political policy; and third, 
so does the bureaucracy. There have been, however, significant powers shifts in the Iron Triangle in the last quarter century. The announcement of the values-based Arc came from this shifting power structure. First, aside from a brief period between 1993 and 1994, and again from 2009 to 2012, the LDP has retained control of government by holding the majority of seats in the Diet House of Representatives, and therefore, the Prime Minister's office since 1955. The LDP has been instrumental in crafting Japan's foreign policy, and defining Japan's role in international order. To many in Japan, the political class is the LDP. While generally characterized as a center-right party with proAmerican inclinations, the LDP is a broadly defined party and is successful more primarily due to its deep pockets and legacy of postwar peace and prosperity than due to ideology. In fact, "[f]actionalism has shaped the fundamental structure of the LDP since the beginning," and these factions compete for leadership within the Party as viciously as parties competing for leadership within other states' governments (Ito 2012).

Second are the major corporations. Fahey argues, “[f]ew of Japan's major corporations are responsive to the demands of central government" (2017). To a certain extent, major corporations do still respond to the central government, but the reverse is still very much alive and well; major corporations - many of which are dependent on exports - have significant investments and interests overseas, and thus maintain at least one vertex of the Iran Triangle to be vibrant to this day. It is conceivable that major corporations wanted to see a foreign policy proclamation like the Arc, which could open up new opportunities for FDI and export markets. Major corporate interests are largely represented by the Keidanren (Japan Business Federation) - Japan's largest and politically most influential business federation. Keidanren could be considered a 
powerful lobby, but it is actually more than just a lobby group; Keidanren often has representation in the legislative councils and 'deliberative councils,' or shingikai (審議 会), within government ministries (Culpepper 2011, 124). With such ties to elected officials, Keidanren is able to pursue its interests and occasionally bypass opposition from the bureaucracy (Culpepper 2011, 124). This was evident by the effect of pro-TPP Keidanren, which won over LDP lawmakers who had long been aligned with the antiTPP agriculture sector lobby (Keidanren 2012). Moreover, it was Keidanren's dissatisfaction with the DPJ's post-Fukushima anti-nuclear power stance that perpetuated the fall of the DPJ and the resurgence of the LDP in late 2012 (Ito 2012).

Third, the elite bureaucracy in national ministries has garnered tremendous clout for many decades which allowed it power in the decision-making process. Bureaucratic positions also garner substantial social prestige in Japanese society; "Japan has benefitted from the fact that some of its most talented youth have elected to make governmental service their careers, and corruption, the scourge of many Asian bureaucracies, has been modest" (Scalapino 2002, 104). Another reason the elite bureaucracy has been able to exercise exceptional power is that cabinet ministers tend to be career politicians "who are moved quite frequently from post to post, often staying in one position less than a year" (Theodoulou 2002, 67). Thus, they may have neither substantial knowledge about ministry or agency functions, administration, or operation, nor are they highly capable of gathering a support base among the career bureaucrats. The power of the bureaucracy, however, started to wane when the Koizumi administration began adopting rules to bypass the influence of the bureaucracy in 2001, and the DPJ attempted to further emphasize these rules when they were in power from 2009 until 2012. The following 
section considers the inter-bureaucratic power dynamics within MOFA and among other influential actors, and how the crafting of the Arc policy possibly took place.

\section{Foreign Policymaking Structure}

MOFA is the headquarters for foreign policymaking, but in some circumstances, MOFA may, in fact, not be the most powerful actor in foreign policymaking since it works together with a host of other actors. Moreover, MOFA is also not a black box; rather, the power structures from within the ministry also dictate how policy is made. There are five regional bureaus within MOFA, as well as several non-regional bureaus. The five regional bureaus are the North American Affairs Bureau, the Asian and Oceanian Affairs Bureau, the Latin American and Caribbean Affairs Bureau, the European Affairs Bureau, and the Middle Eastern and African Affairs Bureau. An ongoing power struggle endures among the regional bureaus within MOFA. Countries along Asō's Arc, and in Muslim Asia, are found in the Asian and Oceanian Affairs Bureau, the European Affairs Bureau, and the Middle Eastern and African Affairs Bureau, but not the North American Affairs Bureau, or the Latin American and Caribbean Affairs Bureau. Bureaus also have regional and non-regional departments and divisions within their own structure.

On account of the postwar occupation by U.S. forces, the Security Alliance, and ongoing American military presence in Japan, the North American Affairs Bureau retains a key position of power within the organization. The North American Affairs Bureau oversees relations only with the U.S. and Canada, but has the capability to force out policy recommendations that originate from bureaucrats in the other bureaus. This has been the norm for most of the postwar era, but in recent years the Asian and Oceanian 
Affairs Bureau has emerged in significance with the rise of East and Southeast Asian economies, and China in particular. Thus, within the organization a power competition is emerging between the dominant North American Affairs Bureau and the emerging Asian and Oceanian Affairs Bureau, which includes a large swathe of the Asian-Pacific region including China, Southeast Asia, and India. The competition developing between the dominant North American Affairs Bureau and the Asian and Oceanian Affairs Bureau could cause neglect to advancing policy of the remaining three regional bureaus, insomuch as the other bureaus are not of interest to either the North American Affairs Bureau or the Asian and Oceanian Affairs Bureau. The competition among these regional bureaus is naturally a competition for resources, but beyond this, many elite bureaucrats are trained area and language specialists, and while job transfers are frequent, area specialists tend to remain in positions associated only with that particular region. Thus, in the competition for policy, bureaucrats become advocates for their respective regions, and compete in the realm of ideas on conceptualizing what region needs the most attention, resources, and elaborated policy.

Outside of MOFA, yet still within domestic policymaking, pressures can be immense from other government ministries and agencies, as well as non-government organizations. Pressures are particularly acute when the state or region has vital economic or energy security interests for Japan. In these cases, METI (prior to 2001, MITI) has a much stronger role in dictating foreign policy, working in tandum with MOFA. Additionally, JETRO, Keidanren, and other business interests will apply pressure on crafting the policy. If the region or state has a relatively high energy security interest for 
Japan, the Ministry of Defense, the National Security Council, the Natural Resource and Energy Agency within METI, and energy businesses will also apply pressure.

With this understanding of the organizational structure of MOFA, and of the domestic actors engaged in the foreign policymaking process, the values-based Arc passed through a complex power-struggle process by the time it was announced. Within MOFA, the North American Affairs Bureau deals with gaiatsu - the American insistence that Japan increase both its leadership role in Asia and also its presence as a coalition partner with the U.S. So, while the North American Affairs Bureau may not promote values-based diplomacy in Asia and the Arc, it benefits by allowing the policy to proceed and, thus, a sufficient response to Washington's ongoing request is fulfilled. The Asian and Oceanian Affairs Bureau also stands to gain, at least the semi-autonomous Southeast and Southwest Asian Affairs Department within the Bureau. This department includes ASEAN nations, but also India, Pakistan, and Bangladesh. The strongest divisions with the bureau, those in charge of Sino-Japanese relations, might have opposed the Arc policy depending on how they interpreted this policy benefitting bilateral relations in the long run. Other regional bureaus partially included along the Arc, such as the European Affairs Bureau (Eastern Europe, the Caucasus, and Central Asia, but not Western Europe) and the Middle Eastern and African Affairs Bureau (the Middle East, but not Africa) likely would have supported the policy, given that both bureaus are relatively weak in the competitive structure, and would have esteemed the partial victory. Of the regional bureaus, only the Latin American and Caribbean Affairs Bureau would not directly have any gains from this foreign policy, but even then, perhaps the shift in 
foreign policy would be interpreted as a new flexibility that would eventually allow for a future change to benefit the bureau.

Outside MOFA, other ministries, agencies, and non-governmental organizations could benefit from such policy. In late 2006, Japan's economy had been steadily growing for nearly five years, but it was hardly recapturing the higher growth rates of the 1980s and a recession was predicted for 2007. Therefore, METI would eager seek increasing access to new markets, and encourage such policy, especially since the early 2000 s growth was predicated on capital investments and exports. The same would be true of JETRO and Keidanren. With more emphasis on stability with a reassurance of alliance with the U.S., the Ministry of Defense and National Security Council would also have ample reason to support the policy.

\section{Conclusion}

Japan's vision of Asia in the twenty-first century takes shape on account of both domestic factors as well as opportunities and constraints in the international system. Japan's vision of Asia interacts with visions of Asia coming from Russia, China, and the U.S., but the Arc, as a new pillar to foreign policy, had to pass through a domestic competing power structure to come into existence.

The three visions for Asia examined in this chapter, as well as Japan's Arc, are conceptualizations with differing overlays over the eastern hemisphere (see Table 3.1). BRI includes parts of Europe and Africa, neo-Eurasianism includes all of Asia and fades into western Europe. The American Pivot to Asia is mostly formulated by the oceans Indian and Pacific. And, the Arc, as the name suggests, covers a swath from Southeast Asia to Eastern Europe. All of these, however, have notable omissions. BRI does not 
mention Japan, and the Arc does not mention China and crowding out the U.S. NeoEurasianism marks Japan as a regional linchpin, but is vague regarding China. The Pivot to Asia is predicated on American alliance with Japan, but seems deliberately intended on containing China. All exemplify an exceptionalism of Self, and the security of Self undergirds all four visions.

The four visions for Asia, and the strategy that undergirds each can be framed in the order versus justice dichotomy, as presented by Hedley Bull (1977) in The Anarchical Society. For the U.S. and to a lesser extent Japan, it is a vision for order, and from this order strengthens security. Bull explains the "proponent of order takes up his position partly because the existing order is, from his point of view, morally satisfactory, or not so unsatisfactory as to warrant its disturbance" (1977: 93). For Russia, and to a lesser extent China, it is a strategy for justice. For Russia, it is to remedy the greatest geopolitical catastrophe of the twentieth century; for China, it is to restore the Sinocentric order interrupted by the Century of Humiliation. Both are seeking in their respective approaches to restore an order which currently does not exist due to 'immoral' causes, but did once in the historical imagination. "[I]deas about justice belong to the class of moral ideas, ideas which treat human actions as right in themselves and not merely as a means to an end" (Bull 1977, 75). The order in these historical imaginations is right, and because it is just. As for an outcome, Bull argues:

"[w]hen demands for justice are put forward in the absence of a consensus within international society as to what justice involves, the prospect is opened up that the consensus which does exist about order or minimum coexistence will be undone. The question then has to be faced whether order or justice should have priority" (1977: 92). 
Russia, China, and the U.S. all exemplify power in Asia with somewhat traditional means - military power, a nuclear arsenal, and security alliances, coupled with their distinguishable economic enticements.

Japan differs in some regards. Few would consider Japan as exuding the scope of power seen from the former three in the twenty-first century, but in the absence of military-based hard power, Japan projects attraction across Asia for its counter-model to this. Countries across Asia are drawn to its ability to exert influence, particularly through economics and culture, despite lacking military power projections. Indeed, Japan enjoys a higher favorability rating than the U.S., China, or Russia across Asia, including Muslim Asia (but not among Chinese or South Koreans). It separates itself from the U.S. by not leading its engagements in Asia with its military sector, and also unlike the U.S., it is Asian. It has more credibility than the U.S. to argue that what is in Japan's best interest is also in all of Asia's best interest. It separates itself from Russia by lacking natural resources and wielding them as strategic tools for geopolitical objectives of power expansion. It separates itself from China by the perceived threat that comes with sheer size and proximity, and by a perception of superior quality of its exports.

Japan benefits by being Asian, but being distant at the same time. Importantly, unlike the U.S., Russia, and China, Japan also benefits by not having domestic conflicts between its Muslim-minority and non-Muslim majority populations. The War on Terror has aggravated domestic tensions for Muslim populations in the U.S., Russia, and China, but not necessarily in Japan, where domestic Muslim populations do exist, but are relatively few, and are not perceived as a security threat. This is a key understanding that 
drives the rest of this project, and is also the crux of Islamic studies scholar Miyata Osamu's 2017 work, Islam's Only Hope: Japan.

Insofar as these visions for Asia are undergirded by security of state, it is a manifestation of post-Cold War globalization and strengthening of regional security complexes (RSCs) across Asia into not a security constellation, but a single, massive security complex. In 2003, Buzan and Wæver argued that Southeast Asia has "merged with Northeast Asia into a larger East Asian RSC," but they then predict this RSC will be "potentially including in the future also South Asia in a huge Asian RSC" (2003: 477). If the America Pivot to Asia turns out to be a Pivot out of Asia, if Asians by and large reject the American Pivot, or if its interpreted to be an Obama policy rather than a Trump policy and therefore abandoned, it would have tremendous ramifications in Asia. "[I]t would strengthen the possibility that the Asian supercomplex would evolve into a full Asian RSC" (2003: 459). Buzan and Wæver add "it would expand the engagement of the Eurasian great powers with the Middle East” (2003: 459). This intensification is already seen, as Moscow's neo-Eurasianism, Beijing's BRI, and Tokyo's Arc all view the Middle East as a cornerstone of their visions. The unspoken part in the American Pivot, however, is its turn away from the Middle East.

Japan has long recognized its geopolitical precariousness as a rather large, densely populated island-nation with minimal natural resources, and has been able to offset this deficiency with an export-based, yet often protectionist economy, and its security alliance with the U.S. The domestic challenges of economic security, societal security, and energy security all equate to existential security. It is Hobbesian in the sense scarcity underlies the source of insecurity and can potentially lead to mistrust and conflict, but not in the 
sense that the viable solutions are to 'restore' its position as a dominant actor in global economics. Domestic policymakering elites want to restore a previously attained security stature, and are unsure of Washington's long-term commitment, Moscow's viability, and Beijing's intentions. Strengthening Asian identity and relations with a broader Asia is a means to attain restoration of security, especially for a state that attained prosperity with export-based economics. 
Table 3.1: Competing Visions for Asia

\begin{tabular}{|c|c|c|c|c|}
\hline & BRI & Neo-Eurasianism & Pivot to Asia & $\begin{array}{l}\text { Arc of Freedom } \\
\text { and Prosperity }\end{array}$ \\
\hline Expanse & $\begin{array}{l}\text { Asia, Europe, } \\
\text { Indian Ocean, } \\
\text { and Africa }\end{array}$ & $\begin{array}{l}\text { (1) near abroad } \\
\text { (2) all of Asia } \\
\text { and eastern } \\
\text { Europe }\end{array}$ & $\begin{array}{l}\text { Indo-Pacific } \\
\text { regions } \\
\text { (includes } \\
\text { Japan, } \\
\text { Australia, } \\
\text { Indonesia, } \\
\text { India) }\end{array}$ & $\begin{array}{l}\text { Southeast Asia, } \\
\text { South Asia, } \\
\text { Central Asia, } \\
\text { Middle East, } \\
\text { and Eastern } \\
\text { Europe }\end{array}$ \\
\hline $\begin{array}{l}\text { Notable } \\
\text { exclusions/ } \\
\text { inclusions }\end{array}$ & $\begin{array}{l}\text { excludes Japan, } \\
\text { U.S.; includes } \\
\text { Russia }\end{array}$ & $\begin{array}{l}\text { Japan, Germany, } \\
\text { and Iran are } \\
\text { regional } \\
\text { linchpins }\end{array}$ & $\begin{array}{l}\text { China is a } \\
\text { driving } \\
\text { motivation; } \\
\text { Russia is } \\
\text { excluded }\end{array}$ & $\begin{array}{l}\text { China and } \\
\text { Russia } \\
\text { excluded, but } \\
\text { other former } \\
\text { Soviet republics } \\
\text { are key }\end{array}$ \\
\hline Declaration & 2013 & $\begin{array}{l}\text { N/A (but } \\
\text { emerged in } \\
1990 \mathrm{~s})\end{array}$ & 2011 & 2006 \\
\hline $\begin{array}{l}\text { Declared } \\
\text { driving } \\
\text { facets }\end{array}$ & $\begin{array}{l}\text { infrastructure, } \\
\text { development }\end{array}$ & $\begin{array}{l}\text { multi-polarity; a } \\
\text { task to connect } \\
\text { (and pacify) East } \\
\text { and West }\end{array}$ & $\begin{array}{l}\text { sustainable } \\
\text { economic } \\
\text { development }\end{array}$ & $\begin{array}{l}\text { infrastructure, } \\
\text { development, } \\
\text { democratization }\end{array}$ \\
\hline $\begin{array}{l}\text { Plausible } \\
\text { underlying } \\
\text { driving facet }\end{array}$ & $\begin{array}{l}\text { resource } \\
\text { security, } \\
\text { restoration of } \\
\text { Sinocentric } \\
\text { order }\end{array}$ & $\begin{array}{l}\text { security, identity, } \\
\text { restoration of } \\
\text { Russian power }\end{array}$ & $\begin{array}{l}\text { Chinese } \\
\text { containment, } \\
\text { unipolarity }\end{array}$ & $\begin{array}{l}\text { identity and } \\
\text { role, countering } \\
\text { Chinese } \\
\text { dominance }\end{array}$ \\
\hline
\end{tabular}


PART TWO: STRATEGY 


\section{CHAPTER IV}

\section{ACCESS TO ENERGY}

In July 2016, Koike Yuriko was elected as the first female governor of the Tokyo Metropolis. Koike is a conservative politician who was a key ally in the Lower House of Prime Minister Koizumi Junichirō. She served briefly as the defense minister in Abe Shintō's first cabinet in 2007, and in 2008 ran as the first woman ever for the position of Liberal Democratic Party (LDP) leadership. Koike is currently among the most popular politicians in Japan, and many predict she has the potential to advance politically to become the first female Japanese prime minister (Sakurai 2017). She is also an Arabist. Koike's father was an international trade magnate who persuaded his daughter that relations with the oil rich countries in the Middle East were key for Japan's economic stability for decades to come. Koike studied Arabic at American University in Cairo, and while working as a translator in Egypt interacted with leaders such as Yasser Arafat and Muammar Gaddafi. When Saudi King Salman visited Japan in March 2017, Koike was among the Japanese leaders who met with the King.

Koike is unique among the Japanese political class in her knowledge and experience with the Muslim world. While it was Japan's dependency on energy resources that attracted her to Arab studies, she has expressed interest in strengthening Japan-Arab relations beyond oil, and praised Saudi Arabia's planning for a post-oil economy during the King's visit (Arab News 2016). Access to energy is the most acute impetus for Japan to engage itself with Muslim Asia for over a half century. Today, oil-rich countries in Muslim Asia such as Saudi Arabia and UAE are indirectly indicating their peak oil moments have passed by planning for post-oil economies. Nevertheless, at present the 
petro-trade still dominates this relationship with Japan, and is still calculated strategically, both in the short- and long-terms. This chapter focuses on how Japan relates to Muslim Asia via access to energy. It is argued that the oil trade has served as a key conduit for long-term relations between Japan and much of Muslim Asia in the postwar era. Moreover, energy security is ontological security for Japan, thus the energy suppliers in Muslim Asia must be secured at all costs to maintain the steady flow of energy resources. At times, this calls for strategic pandering and overlooking democratic and human rights issues, key to the Arc foreign policy, in the interest of ensuring energy resource supply. Nevertheless, this form of relationship between Japan and the Muslim Asia energy suppliers is very much temporary, as seen in the past, and illustrated by energy initiatives for the future. Discussion of planning for the post-oil relations that Koike alluded to are addressed in greater detail in the following chapter.

Which states are key energy suppliers for Japan in Muslim Asia, and which are not? Which regions must be secured for the supply of energy, and in terms of Tokyo's geostrategy, how so? How did this dependency shape Japan's values-based diplomacy and the Arc of Freedom and Prosperity, and how does the Arc shape it? Utilizing typological theory as a methodological tool for analysis, this chapter clarifies the role of energy security in Japan's foreign policy with Muslim Asia. Access to energy is a variable which undergirds the relationship, and has kept Japan attentive to events in the Middle East throughout the postwar era. While talk of the post-fossil fuel global economy is not hopeless, reaction to the nuclear fallout at Fukushima in 2011 proved that fossil fuel imports will continue to dominate Japan's energy sector for the foreseeable future, and remain the key factor in Japan-Muslim relations. 
Energy dependency has been the primary reason to maintain a direct and meaningful linkage in the postwar era between Japan and Muslim Asia. Japan's overwhelming energy dependency, postwar pacifist norms, and even geographic remoteness from energy suppliers have enabled Japan to distance itself from Western states in the image constructed in Muslim Asia states - both resource exporters and others. These same variables, however, are shifting, and thus, can shift the outcome of relations. Much like the West, Japan avoids emphasizing values such as "democracy, freedom, human rights, the rule of law, and the market economy" to resource-rich exporters. By omitting this language with such states, Japan is at worst undermining its true adherence to these norms, and at best demonstrating how its acute dependency on resources from these states to undergird its own survival outweighs the values it emphasizes in values-based diplomacy. Thus, these values apply foremost to Japan's own society, then, depending on energy resource endowments and export potential, they apply to Muslim Asia insofar as they do not interfere with Japan's resource dependency.

\section{Background: A Symbiotic Relationship}

Historically, Japan was able to rely upon its own coal supplies for energy, and even export it to China and Southeast Asia, but Japan's coal was generally of poor quality and insufficient for a modern, industrialized empire. By the early twentieth century when the modern nationstate was just taking form, an acute awareness of its own energy resource deficiency would begin to define Japan's sense of security and self in the international system. Strategy follows this impasse; how to break the limitation? Without access to abundant metals and fossil fuel resources, the modern, industrialized empire could not be 
created. To survive, Japan must emulate the West, but unlike the Western powers, Japan lacked secured access to energy resources.

After consecutive victories in the First Sino-Japanese War, the Russo-Japanese War, and World War I, Japan's military growth took off, and resultantly, so did its need for energy resources. Yet, there was a pervasive, naïve sense that was perpetuated by hubris instilled from the trio of war victories that Japan would always have sufficient energy supplies, despite military and industrial expansion (Nakajima 2015, 34). After all, oil discoveries were taking place at the time in several different regions of the world. Assuming supplies would also be discovered in Japan or in Japanese-controlled territories was not irrational.

After World War I, Japan followed the lead of its alliance partner, Britain, in switching all naval ships from coal power to diesel power. Domestic coal supplies were sufficient for modernization until the 1920s, when Japan's military had several new warships, aircraft, and tanks - all running on petroleum, and not coal (DeWit 2017, 184). “Coal helped motivate Japan’s fateful imperial adventures, but oil delivered a catastrophic lesson in extreme energy dependence" (DeWit 2017, 184). It would not be until the late 1920s, after extensive surveying and several domestic oil companies failing that Japan began coming to terms with the realization that its domestic crude oil reserves would never be sufficient, nor match that contemporaneously being found in the U.S., the USSR, Latin America, the East Indies, or the Persian Gulf (Enayat 1994, 44). Thus, foreign policy and geostrategy would thereafter be shaped by the irretractable need to secure adequate supply of this key resource. Indeed, the institution to take interest in 
formulating a geostrategy to secure foreign crude oil supplies was the same sector that consumed the most: the Imperial Navy.

The first Japanese drawn to the appeal of potential crude oil resources in the Persian Gulf region was geographer Shiga Shigetaka. After traveling to India, Persia, and overland from the Arabian Desert to Damascus, he argued in his 1926 book, The Countries We Do Not Know, that the oil fields in the Iraq-Persian borderlands which he identified as "Maidan-i-naften" contained reserves that were significantly greater than the oil fields Tokyo had been focusing upon at the time in northern Sakhalin, and that "we have to consider [Persia's oil fields] essential to Japan's petroleum strategy" (Nakajima 2015, 38-39). Nonetheless, despite the dominant position Persian Gulf states enjoy today in oil production, they were relatively latecomers to the industry. At the time Shiga predicted the significance of the Persian Gulf region to Japan's energy security, oil reserves were yet to be discovered in Bahrain, Kuwait, UAE, and even Saudi Arabia. Shiga was a prolific writer who had an influence on many, but was before his time. "The Japanese who desired petroleum looked off in a far distance, but to reach the Middle East, first there was Taiwan, the Korean Peninsula, China - and exploitation of petroleum in Japan's Northeast Asian region" (Nakajima 2015, 40).

Many of the smaller Persian Gulf sheikhdoms relied on the pearl industry for an inflow of foreign capital prior to the discovery of crude oil, yet coincidently, it was a Japanese inventor in the late 1920 s who inadvertently destroyed the Persian Gulf pearling industry by inventing marketable cultured pearls raised in pearl farms (Yergin 1992, 293). This, in turn, forced these sheikhdoms to accelerate oil exploration as a new possible source of revenue (Yergin 1992, 293). As Persian Gulf oil reserves were being 
discovered in the 1930s, Japan made efforts to invest, but came across barriers usually involving the enormous transport costs and requisite investment capital, not to mention the dominance by British and American supermajors in the region (Nakajima 2015, 5661). While not productive economically, it turned out to be the beginning of relations between Tokyo and many of the post-colonial states in the Gulf region.

By 1941, half of the crude oil consumed by Japan went to military use, and 60 percent of Japan's crude oil was imported from the U.S. (LaFeber 1997, 200). The awareness of this acute energy resource deficiency was undeniably a key factor in its choice to expand militarily, and seek out energy resources in other territories in Asia. Paradoxically, however, Japan soon discovered that the more it expanded into Asia, the more resources it needed to militarily fortify its possessions. In 1939 Japan announced an 'East Asia Co-Prosperity Sphere,' which was to remove European colonial powers from China and Southeast Asia. Behind the pan-Asianist message lay the imperative geostrategy of securing 'sovereign resources areas,' which meant exploiting the crude oil reserves in the Muslim-populated East Indies to sustain the war effort in China. After the U.S. embargoed all crude oil exports to Japan, the Japanese carried out its attack on the U.S. Pacific Fleet in Pearl Harbor in December 1941 concurrently with an invasion of the Dutch East Indies and British Malaya, which would allow Japan access to the coveted crude oil reserves, what they began calling the 'Southern Zone.'

Despite the Japanese initial success in invading the Dutch East Indies and British Malaya, and securing their crude oil reserves, the strategy of fully exploiting these resources so that they would adequately supply the war effort failed. Dutch and British oil field workers successfully carried out extensive scorched earth policies to their own 
oil fields prior to retreat. Moreover, it should be noted most of these resources Japan was relying upon were reserves - surveyed estimates, not yet producing and equipped for immediate export. Without a strong existing oil industry in Japan itself a dearth existed in technological know-how, sufficient supplies of machinery, and compliant and available manpower. As quick as possible, Japan sent more than 70 percent of its petroleum workers to ramp up production in these fields, but many lacked experience and expertise (Yergin 2008, 338). Nonetheless, they were able to ramp up production from the Southern Zone in a remarkably short amount of time.

Oil production in the Southern Zone under British or Dutch control is estimated at 65.1 million barrels in 1940, yet after one year of Japanese occupation of the same territories, the Southern Zone produced 25.9 million barrels in 1942, and by 1943, 49.6 million barrels (Yergin 2008, 338). In the first quarter of 1943, Japan was importing 80 percent of the amount imported in 1941 prior to the embargo (Yergin 2008, 338). Once Allied forces could reach the waters in the region, oil tankers from the Southern Zone up to Japan became easy torpedo targets for submarines, rendering the target resource of the initial war strategy useless. "By 1944, sinkings were far outrunning new tanker construction" (Yergin 2008, 340). In the first quarter of 1944, crude oil imports were less than half that of the first quarter of 1943; by 1945, crude oil imports were negligible (Yergin 2008, 340). By late 1943, Tokyo was already attempting to find sufficient crude oil supplies at home, or at least closer to home in Manchuria or Karafuto (Sakhalin) (Enayat 1994, 53).

Japan's strategy to attain a sovereign resources area resulted in war and defeat. The "modern, industrialized empire" was demolished, but replaced with a "modern, 
industrialized state," which necessitated securing access to abundant energy resources through a different strategy. By this time, the key resource had long been crude oil, and not coal. Japan was devoid of significant crude oil deposits, and its coal mines were rapidly being exhausted. Densely populated with urbanized youth, Japan needed access to energy resources essential to rebuild, re-industrialize, and avert mass poverty and domestic conflict. Crude oil, and specifically Persian Gulf oil, served as the materiel underpinning for the rise of postwar Japan.

By the late 1940s, Anglo-American supermajors viewed Japan as a prime location for refineries of the flow of crude oil just recently starting to develop in the Persian Gulf. While the distance between the Gulf and Japan is immense, its domestic market was expected to skyrocket with demand. Additionally, while still under American occupation, Japan was the most stable country in the region, and could serve as a regional hub for Persian Gulf oil refineries (Enayat 1994, 67). While this did open up a new avenue of contact between Japan and Muslim Asia, it was greatly constrained. Again, Japan was still an occupied state, and Anglo-American supermajors facilitated this crude oil transport strategy. For the supermajors, it was a strategy that would ensure that they controlled upstream operations, and never have to deal with competition offered from Japanese oil companies, which would focus purely on downstream operations. By the early 1950s, oil refining was among Japan's most technologically advanced industries due to the access to capital and technology transfer gained from the supermajors in Japan (Enayat 1994, 69).

Branching off from its success in the refining industry, after the American occupation ended in 1952 Japan promoted petrochemicals as a national policy industry in 
1955, thus reaffirming that the new economy of Japan would be an oil-based one (Enayat 1994, 76). During this period, Japan would spearhead the development and industrialization of petrochemical technologies, namely utilizing petroleum naphtha rather than coal, as the primary feedstock (Enayat 1994, 258). By 1957, there were four naphtha cracking centers across Japan (Enayat 1994, 267).

In 1958, concerned with Japan's security of oil supplies and deep dependency on the U.S., entrepreneur Yamashita Tarō sought oil fields in the Persian Gulf region for investment. Contrary to the expectations of the Japanese government and the supermajors, Yamashita succeeded in making an agreement with the Saudis and Kuwaitis to explore the Neutral Zone between their countries, discovered oil in the Khafji field, and established the Arabian Oil Company (AOC) in 1958 (Enayat 1994, 80). Yamashita's profit-sharing arrangement pushed the limit at the time. When half of all profits on oil production was the most a country could expect at the time, Saudi Arabia and Kuwait gained 57 and 56 percent of all profits, respectively (Enayat 1994, 80). On account of his activity on the Arabian Peninsula, Yamashita was given the nickname "Arabia Taro."

Between 1948 and 1972, Japan's crude oil consumption increased an astounding 137 times (DeWit 2017, 186)! Access to energy became not only an issue simply of economic security, or energy security, but also, it became an issue of national security. Japan's existence is predicated on solving its energy resource deficiency, and how it both secures access to foreign energy resources, and compensates for this deficiency via its own human capital. Without a steady supply of energy resources from abroad, there is no Japan. 
Through the 1960s, Japan's energy use pivoted from coal to oil - and specifically, Persian Gulf oil. In 1960, coal made up 41 percent of Japan's energy supply while oil made up 38 percent (EDMC 2016, 38, 316). By 1970, coal was just 21 percent while oil was 70 percent (EDMC 2016, 38, 316). In the same period, energy self-sufficiency dropped from 58 percent in 1960 to 15 percent in 1970 as the volume of energy imports rapidly accelerated (METI 2015, 110). During the decade, oil from the Middle East would rise to 90 percent of the total oil imports (Enayat 1994, 83). Yet, despite the shift, it still represented Japan's constrained interaction with the world via the U.S. "Cheap, abundant, and seemingly risk-free oil supplies for Japan were delivered largely from a Mideast region dominated by the United States, through an industry largely controlled by US firms, and over sea lanes patrolled by US warships" (DeWit 2017, 186). In Japan, the biggest beneficiaries of this emerging dependency was Japan's refineries and petrochemical industry.

This chapter continues by examining two cases of crisis: the Iran Japan Petrochemical Company (IJPC), and the 1973 oil shock. Both of these had lasting effects on Japan's perception of energy security, and acutely, how Islam relates to Japan's access to energy. The chapter continues by examining the liquified-natural gas (LNG) market, and Japan's pivotal role in this trade, and concludes by framing these research results into a typology.

\section{IJPC}

Japan was the largest importer of Iranian oil throughout the 1960s and early 1970s, purchasing nearly half of Iran's oil exports (Enayat 1994, 323). In 1971, Mitsui \& Co., in consortium with four other Japanese companies, entered into a joint venture with Iran's 
National Petrochemical Company to develop the Lorestan oil field in western Iran, and construct a petrochemical complex. The consortium was named Iran Japan Petrochemical Company (IJPC). By the late 1960s, rapid industrialization took its toll and due to environmental concerns, Japan was already attempting to encourage companies to expand petrochemical plants overseas, and then import their products to Japan rather than produce domestically. By this point, the petrochemical industry was very vibrant in Japan. ${ }^{1}$ Iran had cheap raw materials, and a surplus of petroleum feedstocks which otherwise were not going into industrial use. The plant was designed to become the largest petrochemical complex in the world (Enayat 1994, 357). IJPC, however, turned out to be a disaster for both Japan and Iran, and would be noted in history as the "tragically unfinished project," leaving Japanese hesitant to invest in Iran thereafter (Kubota 2009, 234).

The venture was scheduled to start in 1973, but construction did not commence until 1976, then was interrupted two years later by the Iranian Revolution. By 1978, the estimated costs for the project had ballooned sevenfold in the matter of seven years due to the quadrupling of oil prices in 1973 and the rapid depreciation of the U.S. dollar relative to the Japanese yen over the 1970s. Loans to IJPC were overwhelmingly in yen, while expected revenues were to be in dollars (for exports) or rials (for domestic) (Enayat 1994, 371). Meanwhile, in 1977 Mobil Oil informed Mitsui \& Co. that after multiple digs, Lorestan was devoid of marketable supplies of proven crude oil reserves. In September 1978, Japanese Prime Minister Fukuda Takeo visited Iran, and inspected the

\footnotetext{
${ }^{1}$ The Russian term "kombinat" had become a loan word in Japanese, meaning specifically a petrochemical or refinery complex, and the prewar Soviet model was adopted for maximum efficiency.
} 
plant construction site in progress, but just three weeks later Iranian workers joined the strikes around the country against the Shah's rule. By January 1979, most Japanese involved with IJPC had taken the advice of the Ministry of Foreign Affairs (MOFA) and departed Iran as the Islamic Revolution heated up. At this point the plant was 85 percent complete (Kubota 2009, 235). In February, Ruhollah Khomeini returned to Iran and established a revolutionary government in the absence of the Shah who had left the country. The Islamic Revolution in Iran would double global oil prices once again, causing even more swelling of the remaining project construction costs.

The new government in Iran was generally hostile toward Western powers and their direct investment in Iran. Unsurprisingly, this concerned the Japanese government as well as the IJPC partners. Yet, the new government in Tehran refrained from including Japan in its antagonistic posture to the West, as its conceptualization of 'the West' was primarily defined by the powers whose imperialism stretched into in the Middle East, or, at least, meddled in the affairs of Iran in the nineteenth and twentieth centuries. Rather, Japan, was praised for its preservation of its culture despite its modernization, economic development, and endurance of American occupation. Moreover, the atomic bombings of Hiroshima and Nagasaki were specifically cited by Khomeini on numerous occasions as cases of 'inhumane acts' by the United States. Thus, despite Japan's FDI project that created the IJPC, and despite the favorable relations Japan enjoyed with the Shah's government, ${ }^{2}$ Japan was able to retain favorable relations through the transition of Iranian

\footnotetext{
${ }^{2}$ The Shah's eldest daughter, Shahnaz Pahlavi, was an investor in Honda motorcycle and bicycle assembly plants in Iran, and his nephew, Prince Shahram Pahlavinia, was a business agent representing Japan Air Lines in Iran (The Leader-Post 1979, 41).
} 
governments both before and after the revolution. To illustrate its commitment to relations with Japan, the first crude oil export carried out in post-revolution Iran was to Japan in March 1979 (Enayat 1994, 376).

Confident the new government in Iran was committed to the IJPC, plans were made to proceed with the plant construction on 11 November 1979. These plans were thwarted just one week earlier when the American embassy in Tehran was invaded and its employees were taken hostage by the invading student radicals. The Japanese were stuck in a challenging diplomatic position. On one hand, there was enormous sunk cost in the IJPC construction project, which was Japan's largest FDI project at the time, and the need to ensure the steady supply of Iranian oil exports, which were roughly 12 percent of Japan's total imports (Enayat 1994, 378). On the other hand, there was genuine sympathy for the American hostages, Japan had its security alliance with the U.S. to consider, and was acutely concerned about the safety of its own nationals in Iran. Amid the hostage crisis, in January 1980 the U.S. was asking its allies, including Japan, to impose economic sanctions against Iran. ${ }^{3}$ Fortunately for Japan, European countries were also not enthusiastic about harsh economic sanctions against Iran, and Tokyo was able to get away with minor, insignificant sanction measures similar to what many European countries did. Tokyo made conscientious efforts to keep the IJPC project outside of any economic sanctions.

In 1980, negotiations were conducted to continue with the IJPC construction project with new management appointed from the new Iranian government, and in spite

\footnotetext{
${ }^{3}$ Sanctions are discussed in detail in Ch. 8 .
} 
of the American hostage crisis. Japanese workers had just arrived on site to recommence construction in September of that year when Iraq invaded the Khuzestan Province in southwestern Iran, where the IJPC site was located. Within two days of the invasion, the Iraqi Air Force had bombed the plant site. By November, Mitsui \& Co. wanted to pull out of the project, and was hoping to collect insurance indemnity to cover some of its losses, but the Japanese government, and specifically the Ministry of International Trade and Industry (MITI), would not allow Mitsui \& Co. to collect on insurance indemnity, and persuaded the company to remain invested in the project (Enayat 1994, 393). For the Japanese government, too much was at stake for Mitsui \& Co. to let it go. Firstly, it was the largest FDI project Tokyo was engaged in at the time. Secondly, the Soviet Union had just invaded Afghanistan less than a year earlier, and Tokyo was concerned that the Soviets might eventually gain access to and control of Iran's oil reserves. If Mitsui \& Co. pulled out, Tokyo was concerned the Iranians might allow the Soviets to fill the void on the project.

On October 14, Japan withdrew its government personnel from Iran due to the war. Iraq warned Japan that it would continue to bomb the site if construction continued, so Japan left with the commitment to Iran that construction would recommence after the war was over. While Japan never did recommence construction during the war, Iraq, in fact, continued to bomb the construction site up to 42 times, as it was within 100 miles of the Iraqi border and was a key target with significance to Iranian economic development (Enayat 1994, 414). After the war ended in 1988, the Japanese inspected the site to assess a cost estimate to continue the plant project. On account of corrosion and bomb damage on the mostly-completed facility, they estimated it would cost over $\$ 6.5$ billion - more 
than ten times the original estimates (Enayat 1994, 418). While the Iranians disputed this estimate, they could not stop the Japanese investors from giving up on the project. In 1989, both sides entered the 'Friendly Separation' talks. Fortunately for Japan, Iran's newly elected President Hashemi Rafsanjani was strongly in favor of deepening ties with Japan, and was of the opinion that petty disputes with Japan on the IJPC plant project would prevent the Japanese from joining other projects in Iran, and be detrimental in the long run (Enayat 1994, 420). This is precisely how the Iranians spun the outcome, when the final 'Friendly Separation Agreement' was signed in October 1989: "this would pave the way to building a new relationship between the two countries" (Enayat 1994, 421). Upon the Japanese departure, IJPC was renamed Bandar Imam Petrochemical Company (BIPC), and in a joint venture with several European companies, it was completed in 1994 as the largest petrochemical plant in Iran. The IJPC experience indeed paved the way for a "new relationship," but one where the Japanese lost interest in FDI in Iran.

\section{0s Oil Crises}

On 6 October 1973 Syria and Egypt initiated a surprise attack on Israel, posing the greatest existential threat to the state since its inception in 1948. Within a week, U.S. Secretary of State and National Security Advisor Henry Kissinger began an aerial bridge strategy to supply armaments to Israel, which allowed Israel to quickly turn the tide in the short-lived war. On 17 October, oil ministers from the Organization of Arab Petroleum Exporting Countries (OAPEC) agreed to implement two measures: first, successive production cuts globally; second, a crude oil embargo against the U.S. and the Netherlands (which granted runways for stopovers in the U.S. aerial bridge). The former measure was intended for U.S. allies, including Japan, to place additional pressure on 
Washington to stop supporting Israel in the war. The production cuts went in stages, first ten percent, and then another of 15 percent. By November, global production was cut over a quarter of the previous month, fueling a massive price surge.

In December, the OAPEC measures were met with delight from non-OAPEC members of the Organization of Petroleum Exporting Countries (OPEC), such as Iran, which welcomed the OAPEC politicizing of crude oil. Prices increased from $\$ 2.50$ per barrel to over $\$ 12$ per barrel within just a few weeks (Chalabi 2010, 113). Demand was so high, in December the Iranian National Oil Company quietly put up some quantity of crude oil outside of OPEC-controlled prices into an international auction to test the market, where Japanese companies paid \$18 per barrel for the oil (Chalabi 2010, 111).

When the 1973 oil shock hit, over 75 percent of Japan's energy was coming from crude oil, and nearly 80 percent of that crude oil came from the Middle East (Hosaka 2013/2014, 67). Three-fifths of Japan's primary energy came from the Middle East (Hosaka 2013/2014, 67). If Japan were to risk being labeled a supporter of Israel and hit with an embargo on par with that against the U.S. and Netherlands, nearly all this energy would be lost, returning the postwar economic miracle essentially to the stone age.

Along with implementing domestic ad hoc conservation measures, diplomacy directly with Persian Gulf suppliers was necessary. The first step was to establish clarity regarding the suppliers' objective with Japan. Clear overtures had to be made so that Japan could avoid the embargo status placed on the U.S. and Netherlands, and at least keep itself positioned similarly to the UK or France (Hosaka 2013/2014, 67-68). Deputy Prime Minister Miki Takeo was immediately dispatched to OAPEC states prepared to increase economic aid packages in exchange for reinstating crude supplies to Japan. Of 
the 3 trillion yen in long-term economic assistance pledged in this quick ad hoc trip by Miki, a third of it was directly to Iraq, ${ }^{4}$ the OAPEC member that showed both the greatest need for economic assistance and hesitancy regarding the supply disruption policy (Miyata 2017, 61). In return, Iraq guaranteed 90 million tons of crude to Japan over ten years, despite cut-back commitments to OAPEC (Miyata 2017, 62).

To be labeled an 'unfriendly' nation was a great shock to the Japanese, who concern themselves deeply with the impression of their country around the world (Hosaka 2013/2014, 68). The Japanese could not grasp how they could be considered a friend of Israel, rather than the Arabs. "Setting aside the energy issue, the relationship between Japan and the Middle East is not necessarily deep; rather, one could say issues of politics, history, ethnicity, and religion in the Arab-Israeli conflict have essentially no relation to the Japanese" (Hosaka 2013/2014, 68). Moreover, Japan had been a tremendous source of aid for the Palestinians, even surpassing the amount provided by Saudi Arabia in monetary aid (Hosaka 2013/2014, 68).

The oil shock strengthened the political posture of MITI, which seemed to have more power in dictating foreign policy than MOFA. After the Deputy Prime Minister, MITI's top diplomat (and future prime minister), Nakasone Yasuhiro, was dispatched to the Middle East to renegotiate bilateral relations. He touted a concept new to Japan's foreign policy, "resource diplomacy," which advocated for distancing its own foreign policy from that of the U.S. (Yergin 1992, 599). He clarified that with 'resource diplomacy,' Japan must be "standing on the side of the oil producing countries" (Yergin

\footnotetext{
${ }^{4}$ Discussed further in Chapter 6.
} 
1992, 599). MITI also developed a new national energy policy which called for the increased utilization of nuclear energy, and a wider diversification of crude oil suppliers, including China from which imports increased 100-fold in the matter of two years (LaFeber 1997, 362)!

Japan had not seen such vulnerability to resource supply disruptions since the U.S. crude oil embargo in 1941. Yet, similar to 1941, it was a matrix of international alliances that perpetuated the supply disruption. Unlike 1941, however, religion played a major role in the 1973 oil crisis. It also had another impact on Japan, which was not an outcome seen in the U.S. or Western Europe; MITI employed a program to transition the energy-consuming heavy industries such as steel and textiles into services and hightechnology industries such as electronics (LaFeber 1997, 362). Meanwhile, Japanese automobile manufacturers began designing smaller vehicles, that maximized fuelefficiency. The ramifications of the 1973 oil shock were so great in Japan, even in comparison to Western countries, that it spurred a radical response from MITI that would not only buffer Japan from the effects of the second oil shock in 1979, but also allowed it to rapidly transition to an economy less dependent on oil imports, and cultivated an investment environment that encouraged the development of small, fuel-efficient automobiles that coincidently were of great demand overseas. From the first oil shock until 1986, Japan's energy consumption grew only 7 percent, yet during the same period its GNP surged by 50 percent (LaFeber 1997, 362). The 1973 oil shock inadvertently contributed to the Japan miracle of the latter 1970s and 1980s.

Diplomatically, it had a great impact on Japan's relations with crude oil suppliers in Muslim Asia, including the Persian Gulf states as well as Southeast Asia. Japan had to 
craft a new foreign policy posthaste which maintained the security alliance and close ties with the U.S., yet somehow attaining the 'friendly nation' status by OPEC members (Sugiyama 2008, 8). On December 12, Miki visited the Saudi King and was assured friendly nation status, and on December 25 it was officially announced that OPEC had accepted Japan's status as a friendly nation, and would restore its crude supply to the September standard for supply (Sugiyama 2008, 8-9). While this was a diplomatic success in restoring supply, it could not improve what would be a new standard in price. Market price would now be substantially higher than consumers were used to, and the crisis transformed from a crisis of supply to a crisis of price (Sugiyama 2008, 9).

The 1973 oil shock affected all developed economies that were highly dependent on crude oil from OAPEC suppliers, but due to Japan's extraordinary high dependency on Persian Gulf oil which far surpassed American or European dependency, Japan was hit the hardest by the oil supply disruptions. By the time Islamist revolutionaries overthrew the Shah of Iran in 1979 perpetuating the second oil crisis, MITI's strategy was successful in buffering Japan from supply disruptions in the Middle East, albeit not entirely.

It was these disruptions in energy security, and thus Japan's economy that contributed to the creation of a comprehensive security policy in 1980, quite innovative for the time as a national security policy. Grasping that American hegemony across Eurasia had reached a critical peak after the 1973 retreat from Vietnam, the gradual but deliberate reduction of troops in South Korea, and the failure to sustain the Shah in power in Iran, coupled with Japan's increasingly role as the most dominate purchaser in the global oil market, policymakers and academics were selected for a research group to 
design a new national security policy (Barber 2016). In 1980, the new national security policy was outlined, based on an innovative concept of 'comprehensive security,' which was conceptualized as an integration of elements, creating a synergy by working together, such as the military, economic, and societal security sectors working in tandem against threats. In short, comprehensive security is "multiple security sectors...collaborating in a network to collectively improve and ensure the security of the referent objects" (Barber 2016). With the new comprehensive security policy of 1980 came a deliberate push to increase Japan's electricity generation from nuclear energy. With regard to the dependence on crude oil imports, the Anglo-American supermajors that had dominated exports of Persian Gulf oil to Japan, had lost their grip on the industry. Tokyo would at last have to learn direct-diplomacy with leaders of nationalized oil companies (NOCs). Energy security had been elevated to high-politics once again.

These events also forced Japan's policymakers to take a fresh look at the Middle East, and expand knowledge on the region into order to develop a coherent energy security strategy. Part of this was retaining Japan's alliance with the U.S., and supporting the Carter Doctrine, so that U.S. military would ensure the transport of crude oil and LNG from the Persian Gulf region, through the Strait of Hormuz and on to Japan. The other part was to keep Japan in a moderate position as to avoid being considered an enemy state by energy-resource suppliers in the region. Japan had to learn how to benefit from the American security umbrella, but at the same time, keep its distance from the U.S. in the view of those in the Middle East. To that extent, Japan's balancing act has succeeded supremely. 


\section{LNG}

On account of its population, level of industrialization, and status as an island-nation, Japan has been a major consumer, if not, the major consumer of liquified natural gas (LNG) for the last half century. Given the very low level of density of natural gas, storage and deliverability are the biggest challenges for the natural gas trade, especially in comparison to fossil fuels in solid and liquid forms. Coal and crude oil, as solids and liquids, can be easily transported overland or overseas, and stored in silos or tanks, respectively. As a vapor, natural gas escapes easily. The cheapest and simplest option to transport and store natural gas is via pipelines which run overland, and at times overseas if for short distances and in shallow waters. Pipelined natural gas makes up 74 percent of the global trade (Tolwer 2014, 98). The only other option is LNG. When natural gas is cooled to $-259^{\circ} \mathrm{F}\left(-165^{\circ} \mathrm{C}\right)$ at atmospheric pressure, it is liquified and contracts to one sixhundredth the volume of its gaseous state. The LNG is transported on specially-designed trucks, railroad cars, or open-sea tankers with insulated walls and auto-refrigeration.

Once it arrives at its destination port, the LNG is re-vaporized at LNG import terminals, then stored in pipelines or shipped for consumption.

In the 1960s, Japan was using mostly crude oil for home electricity. In the interest of improving environmental conditions, by the end of the decade power companies began transitioning to natural gas, but on the condition the government would subsidize the high cost. In 1970, Japanese energy companies participated, for the first time, in a project to import LNG from the British protectorate, Brunei. The joint venture resulted in the first LNG complex in the Western Pacific, the largest LNG complex to date, and the entrance 
of Brunei into the global LNG market. It also provided Japan with a 20-year contract to import LNG.

After the 1973 oil crisis, Japan sought to diversify its electricity fuel sources even more. It played a pivotal role in introducing two more Southeast Asian majority-Muslim states into the LNG market, while deepening ties with them. Japanese companies invested in the construction of LNG export complexes in Indonesia, which began supplying Japanese electricity generators by 1977 . Throughout the decade of the 1980s, Japan's LNG imports surged, and Japanese companies also invested in the construction of the first export complex in Malaysia. In 1984, Japan was purchasing 72 percent of global LNG sales (Petroleum Economist 2004). This ratio dropped to 66 percent in 1999, 48 percent in 2002, and 34 percent in 2015, but Japan was still the world's single greatest purchaser by a wide margin (Petroleum Economist 2004: Tolwer 2014, 98).

Observing the model set by the Southeast Asian Muslim states, Qatari Emir Hamad bin Khalifa al-Thani set out with a plan for Qatar to join the LNG market. A latecomer, Qatar did not export LNG until 1997 when the Qatargas 1 complex was completed. Only Russia and Iran have greater proven natural gas reserves, but Qatar has been able to present itself as a much safer, more stable investment environment when compared to the other two suppliers, and by 2014 it occupied nearly a third of global LNG sales (Reed 2015, B1).

Japan has 23 LNG import terminals and an LNG tanker docks in the country every 20 hours (Montgomery 2010, 87). While there are greater consumers of natural gas, those countries tend to rely on domestic supplies (the U.S., Russia, and Iran) or benefit mostly from natural gas delivered via transnational pipelines (China). Japan dominates 
the LNG consumer market because it is one of the largest energy consumers in the world, it is the most highly-populated island-nation second to Indonesia (which has sufficient natural gas supplies for domestic consumption), and being at its nearest 120 miles from continental landmass, it lacks the availability of natural gas via pipelines.

There is, however, a pipeline opportunity from a neighboring Russian island: Sakhalin. Russia has talked for decades of a potential pipeline project from the natural gas fields in Sakhalin to Hokkaido. Indeed, Japan imports significant quantities of LNG from Sakhalin, but despite the appeal of significantly cheaper pipelined natural gas from Sakhalin, Japanese investors are wary due to past experiences. A pipeline project from Sakhalin is estimated to cost $\$ 6$ billion, and could potentially lower electricity costs in Japan as much as 30 to 40 percent, but Japanese energy companies have already invested tremendous amounts of money in LNG import terminals over several decades, and show little interest in diversifying to invest in a pipeline from what is considered an unreliable supplier (Tanaka 2017). Noteworthy as well is the territorial dispute between Russia and Japan over the Southern Kurile Islands, which "acts as a constraint on enhanced energy and economic cooperation" (Koyama 2013, 286). Expensive, yet reliable energy supplies trump more affordable, yet unreliable supplies. Despite Sakhalin's proximity - less than 30 miles from Hokkaido's northern coast - and the potential for a pipeline, Japan continues to rely on its 'traditional' suppliers of LNG, Australia, Qatar, Malaysia, and Indonesia, because they have exhibited greater reliability. ${ }^{5}$

\footnotetext{
${ }^{5}$ Risk of supply disruptions from Qatar was elevated in 2017 when it was ostracized in the Sunni Muslim world and the Gulf Cooperation Council (GCC). Japan had to make efforts to remain on the sidelines of the inter-GCC conflict because any indication of 'taking sides' would have jeopardized crude oil supplies, LNG supplies, or at worst, both.
} 


\section{Japan's 'Essential Suppliers'}

Given that energy security undergirds existential security for a state like Japan which is deeply dependent on foreign energy resources both in aggregate quantities and proportionally, certain essential suppliers of energy resources are assumed to get a pass from values-based foreign policy. Talk of democratization and human rights, as pillars of the values-based Arc foreign policy, is expected to be absent in bilateral relations with essential energy suppliers. Yet, who are these suppliers in Muslim Asia?

'Essential suppliers' are conceptualized here as the states that provide key energy resources to Japan which sustain its economic, political, and social identity. These energy resources are specifically the fossil fuel resources - natural gas (in the LNG form), crude oil, and coal. Japan is the world's oldest and largest importer of LNG, and will continue to play a dominant role as a consumer in the LNG market, especially after decommissioning dozens of nuclear reactors in the aftermath of the Fukushima Daiichi incident. It is the fourth largest importer of crude oil - after the U.S., China, and India yet these three have substantial domestic reserves they can tap into, which Japan does not. Japan is the world's third largest importer of coal, after China and India - yet again, unlike these two, it long ago exhausted domestic supplies. These three resources, alone, make up over a quarter of Japan's total imports in cost, and without consistent LNG, crude oil, or coal supplies, the essential functions of the state and society would not sustain. To start, which states in Muslim Asia supply Japan with crude oil, LNG, and coal? 
While still significant, coal is the least essential resource of the three, making up less than three percent of Japan's total imports. Only one Muslim Asian state is an essential supplier of coal for Japan, and only one is a potential essential supplier. In 2015, Japan imported 192 million tons (Mt) of coal. The vast majority of which came from Australia (124.6Mt), Indonesia (35.7Mt), Russia (14.2Mt), Canada (8.3Mt), and insignificant quantities from others including the U.S. (IEA 2016, 71). Supplying Japan with nearly a quarter of its coal imports, Indonesia is the only essential supplier of coal to Japan in Muslim Asia (see Table 4.1). It is common for Japanese companies to obtain excavation rights, and control their own coal mining operations overseas, with the help of the government in Tokyo. Most operations in Indonesia are controlled by Japanese companies (IEA 2016, 71). While secondary to Australia, Indonesia has supplied Japan with coal since the late 1980 s, and is integral to its strategy to retain reliable supplies of coal, and diversify its sources (IEA 2016, 72).

Kazakhstan is the only potential essential supplier. Japan does receive negligible quantities of coal from Kazakhstan, yet Kazakhstan is a significant producer and exporter of coal. Moreover, Kazakhstan has over 33 billion tons in proven reserves of coal. While domestic consumption of coal is relatively high, this is one of the largest proven reserves in the world, and given Kazakhstan's relatively small population, can be exported at a greater rate. The greatest challenge for Japan is intense competition from emerging and energy-starved economies in China and India - both benefitting from relative proximity to Kazakhstan. Another immutable barrier which cannot change is geographical Kazakhstan is landlocked, and transporting coal (or any resource product) to Japan would 
require traversing borders, and switching the cargo from overland to overseas. It would make this market possible, but not likely.

\section{LNG}

Early LNG suppliers from Muslim Asia were the ones nearest to Japan - the southeast Asian states, Indonesia, Malaysia, and Brunei, which were among the first to receive heavy investment from Japan to acquire LNG export complexes in the 1970s and early 1980s (see Table 4.2). While Indonesia, Malaysia, and Brunei have continued to provide Japan was substantial LNG supplies over several decades, changes are expected soon (see Table 4.3). Brunei has long passed its peak natural gas moment, and since the initial two export complexes were constructed by the Brunei government, Shell, and Mitsubishi in 1973 and 1974, no other complexes have been constructed, and no new ones are planned (IGU 2017, 65-68). The two LNG export facilities are in need of upkeep, and Brunei is finding itself more dependent on Japan than vice-versa.

Malaysia and Indonesia are newly industrialized economies, and experiencing tremendous growth in domestic demand for energy resources. Particularly in Indonesia, LNG exports to Japan have fallen from nearly half of Japan's imports in 1995 to less than ten percent in 2015. Indonesia's global LNG exports have also fallen a third from 2005 to 2015. Indonesia is unique among LNG suppliers in that while it is still expanding capacity, increasingly sales of LNG are taking place domestically from island to island, within the archipelago, which is constraining its LNG export volume in the international market (Hertzmark 2016, 1). Malaysia, however, has remained as a significant supplier of LNG, providing nearly a fifth of Japan's LNG in 2015 - second only to Australia. Malaysia's production of LNG has continued to increase over the last two decades, 
retaining over a tenth of the global market, and it is still expanding its export capacity with more export complexes currently under construction. Malaysia will remain an essential supplier of LNG for the next decade, but Indonesia and Brunei have dropped from this position.

From the Persian Gulf, Qatar has emerged as an essential supplier, providing Japan with 15.6 percent of its LNG in 2015, and eagerly seeking to strengthen the relationship. Qatar controls nearly a third of the LNG global market, and has the third largest proven natural gas reserves in the world. Iran is not a supplier of LNG, but its first LNG export complex is under construction and scheduled to operate by 2019. This presents enormous potential. Iran has the second largest proven natural gas reserves in the world, surpassed only by Russia, but it has yet to partake in the LNG market. Because of this, Iran is a 'potential essential supplier' because of its imminent potential as a supplier, and not because of its current output. U.S.-led sanctions put this potential in question. For different reasons, another potential essential supplier is Turkmenistan. It has larger proven natural gas reserves than Saudi Arabia, yet landlocked and underdeveloped, exporting its product via LNG tanker rather than pipeline is challenging, though not impossible. Saudi Arabia is also a potential essential supplier for unique reasons. The dominant global crude oil supplier, Saudi Arabia has proven natural gas reserves that surpass those of the U.S., and associated natural gas attained during crude extraction is used almost exclusively for domestic consumption. Yet, Saudi Arabia does not actively take part in the export of natural gas, either by pipeline or LNG tankers (it does not have any LNG export complexes). Nonetheless, if Saudi Arabia were to open up to this 
market, it could provide essential LNG to Japan, given the quantities of proven reserves it has.

UAE has a unique position as a global LNG supplier, albeit a minor one, yet as a major consumer of natural gas, it is simultaneously an importer of pipeline natural gas (exclusively from Qatar) (World Energy Council 2017). Its LNG exports, specifically from Abu Dhabi, are almost exclusively to Japan, but are underdeveloped and can potentially be ramped up. UAE was the first Persian Gulf state to export LNG, when its first export facility (with Mitsui holding the largest ownership stake among foreign investors) was completed in 1977 (IGU 2017, 65). UAE is thus an essential supplier with deep ties and the foundation for a long-term relationship with Japan.

Other LNG suppliers to Japan in Muslim Asia include Oman and Yemen, both have fewer proven reserves and indicators show they have both passed their peak natural gas moments. Oman supplies no more than three percent of Japan's LNG imports, and Yemen has never produced more than a fraction of a percent. Oman maintains high domestic natural gas consumption, which prevents it from obtaining a larger presence on the global market. It has already announced its intentions to withdraw from the LNG market completely by 2025 (IGU 2017, 23). Yemen was a newcomer to the LNG export market when its two export complexes were completed in 2009 and 2010, yet investors declared force majeure and took them offline in 2015 on account of the civil war. Neither can be considered an essential supplier or a potential essential supplier.

\section{Crude Oil}

Two essential suppliers of crude oil easy to identify are Saudi Arabia and UAE (see Table 4.4). Together, these two account for nearly 60 percent of Japan's crude 
imports in 2015. Globally, they account for 16.9 of production, but a significant percentage higher in exports. They also have among the highest proven reserves and reserve life remaining. While remaining essential suppliers, albeit at a lower threshold, are Qatar and Kuwait, each of which has supplied Japan with nearly a tenth of its crude imports for the last two decades. Their proven reserves are smaller, but both are significant suppliers to Japan with decent reserve lives. Indonesia was once a major supplier to Japan, but on account of increased domestic consumption as well as dilapidation of the oil industry infrastructure, exports to Japan have fallen to insignificant quantities.

Iran and Iraq are both potential essential suppliers. Each has proven oil reserves that surpass 100 billion barrels, ranking them second and third, respectively, in all of Eurasia, with extensive reserve life capacities, yet both have seen constrained production on account of economic sanctions and lack of foreign investments. Japan has long taken interest in strengthening ties with each of these countries and access to their energy resources, but has been met with disappointment. Stability and order in Iraq will increase the needed investments to develop its oil industry, especially for the risk-adverse. In Iran, development of the oil industry is predicated on the possible expiration of U.S.-led economic sanctions and adherence of all parties to the Iranian Nuclear Agreement, not to mention the Saudi-Iranian geopolitical rivalry.

Within Muslim Asia, Kazakhstan is also a significant supplier of crude oil creating great interest among major consumers. Kazakhstan has substantial crude oil reserves which surpass Qatar, but as with coal, the constraints of transporting the product from a landlocked state to an island-nation are immense, and for now preclude it from 
becoming an essential supplier. The solution may be oil swaps, most likely with Iran serving at the intermediary.

It is important here to note a typology of Japan's current essential suppliers and potential essential suppliers for the future, because energy security is a significant factor in Japan's strategy in Asia. Considering the themes of the next four chapters, a country's status as an essential supplier or potential essential supplier of energy resources, namely crude oil, LNG, and coal, will affect the other factors in relations with Japan. Table 4.5 shows the essential suppliers and potential essential suppliers of energy resource identified in this section.

\section{Conclusion: Where is Islam?}

This balance of being a key ally in American eyes, yet distant from the U.S. in Muslim eyes had worked for Japan since the 1973 oil shock, but Japan was challenged once again in 2011. The 11 March 2011 Tōhoku earthquake and tsunami happened during the Arab Spring and ongoing sanctioning of Iran. The triple disasters and subsequent aversion to nuclear power in Japan necessitated more fossil fuel imports - much of it from the Middle East. The concurrent Arab Spring raised prices on oil, and due to the Japan Customs Clearing pricing structure, LNG as well. ${ }^{6}$ The ongoing sanctioning of Iran due to its nuclear crisis reflected a degree of irony, given Japan's experience at Fukushima, but also limited the supply of crude oil to Japan, and thus, increased the price as well.

\footnotetext{
${ }^{6}$ Labeled the 'Asian premium,' the LNG pricing index used in Asia is usually linked to the Japanese Customs Clearing (JCC) (often derided as the 'Japanese Crude Cocktail') price for crude oil (Jensen 2004, 26), which directly pegs the price of LNG to the market price of oil (Koyama 2013, 284: Weems and Howell 2014, 4). This became acutely evident to the Japanese when the Arab Spring drove up prices of both oil and LNG on the JCC pricing index, but market-based LNG prices on the Henry Hub index, used in North America, were relatively low at the time (Koyama 2013, 284).
} 
Also, simultaneously occurring was the planned American withdrawal from Iraq to be completed by the end of that year. It put into question American commitment to the region and to the Carter Doctrine. The events of 2011 forced Japan to take an even greater interest in the Middle East so that it could refine its strategy to retain stability of energy supplies from the region.

Stability of supply is paramount for Japan, but remains challenging to assure. Japan attempts to remain unbiased in regional geopolitical contestations, but finds itself wrapped up in these contestations nonetheless. In one example, in 2016 Idemitsu was set to merge with a competitor, Showa Shell Sekiyu, yet the merger was fraught with an unexpected geopolitical challenge in the Muslim world: Idemitsu was a key importer from Iran, and Showa Shell was partially owned by Saudi Aramco. In 2017, several Gulf states, led by Saudi Arabia, severed diplomatic relations with Qatar out of concern it was supporting terrorist groups. With Qatar as a key supplier of LNG for Japan, it was a contestation between essential crude oil suppliers versus the key LNG supplier. Any indication of taking sides would sacrifice the supply of either crude oil or LNG to Japan. Japan's Saudi crude imports are much more significant in quantity and value than its Qatari LNG imports, but no more crucial. Less crude supply drives up costs for factories and drivers most: less LNG supply could cause blackouts (Fickling 2017). In both these recent cases, religion was at the core of the conflict, and Tokyo was compelled to take interest.

Access to energy has dominated Japanese thinking in foreign policy, as it undergirds the existence of the state. Access to energy has also drawn Japan to relations with Islam, because it draws Japan into transactions with Muslim peoples. Some may 
claim there is no 'Islam,' and there is no securitization of Islam in the straightforwardness of energy business transactions, but this claim is greatly erroneous. Japanese businesses are notorious for their cautiousness in FDI projects. At any given time and place, in the mind of energy geo-strategists, projects and potential projects oscillate from 'easy oil' to 'tough oil' to 'risky oil.' These terms are specific to the oil industry, but are just as applicable to other energy resources, like natural gas, coal, and uranium. Tough oil is 'tough' due to geology and technology. The questions asked are, "Is it hard to reach?" and "If so, how much does that increase production costs?" Risky oil is political. Easy oil can turn risky on a whim due to political developments. Investors want to avoid these locations as much as possible, but at times when demand is high, they have to venture into risky oil. Japanese businesses value long-term relationships, and have an inclination to negotiate for these when a strong rapport has been developed with a supplier. For cautious investors, it is a confidence-building measure.

In the postwar era, the biggest disruptions to the supply of energy to Japan have been on account of conflicts within Islam. To argue Islam is not present in business negotiations, or it is not securitized by the Japanese is to ignore the events of the near past. The 1973 oil shock was not just ethnic-Arabs reacting to Jews in Palestine; lest it is forgotten that it was Iran, a non-Arab state, that enthusiastically widened the embargos and cut-backs. The Islamic Revolution in Iran interfered with Japanese investment and access to energy. This, too, was religious, and for better or worse, taught the Japanese more about Islam than they had ever known. The subsequent Iran-Iraq War continued to interfere with supply and investment; it, too, was predicated on the Sunni-Shi'ite split in Islam and the effects it had on the apparatus of the state. Whether Japanese energy geo- 
strategists consider Iranian oil risky, or Qatari LNG easy, or Kazakhstani coal tough is wrapped up in securitizing threats to their energy supply from Islam based on the historical record.

The source must be secured, yet that says little about the transportation route. Roundtrip voyages for fuel tankers from the Persian Gulf to holding facilities in Tokyo Bay take 45 days (Sudō 2014, 32). These tankers follow a long maritime highway tantamount to an umbilical cord for Japan; disruption on this highway cuts Japan off from its fundamental security. There is much to be secured, and building long-term relationships with suppliers, where both parties gain a sense of satisfaction from the positive-sum transactions, is a key strategy in ensuring both sides react similarly to disruptions in this linkage. In this sense, Japan is obliged to coexist with Islam, for its own existence.

\section{Toward a Post-Oil Era}

There is much talk of moving beyond the age of fossil fuels both among consumers and suppliers, and indeed, technological advances in alternative energy sources are curtailing fossil fuel consumption in many parts of the world. Unlike the U.S., where many are motivated to curb fossil fuel dependency from the Persian Gulf because of how the petrodollars may be used against American interests ("buying oil from people who hate us"), Japan is more concerned with (re)attaining some practical amount of energy selfsufficiency. Japan is among the consumers who are pressing forward with technological advances to curtail fossil fuel consumption. The Fukushima incident and subsequent aversion to nuclear energy in Japan set back the initiatives to curtail fossil fuel consumption, but it has also spurred interest in renewable, domestic sources of energy. In 
2012, Japan introduced feed-in tariffs (FITs) on account of the efforts by Prime Minister Kan Naoto who pushed the legislation through the Diet, and Softbank CEO Son Masayoshi who began investing in a solar power network (DeWit 2014, 127). By 2013, Japan's FITs were the highest in the world, yet the overall price of solar power continued to decline (DeWit 2014, 127). Solar panels, once a rare sight prior to Fukushima, are now seen throughout the countryside in Japan.

Nonetheless, this solar revolution in Japan has done little to bring down fossil fuel dependency, let alone to fill the gap left by dozens of decommissioned nuclear power plants. Since the arrival of Americans in 1853, Japan has had an acute sense of inferiority in the international system, and this is not by any means a societal inferiority, but purely one of resources. This deep dependency on certain Muslim Asian states for its energy resources, however, will not last long into the future. Indonesia has already passed its peak oil moment, and its coal supplies are not extensive. Saudi Arabia, Kazakhstan, UAE, and Brunei are all planning for post-oil economies. In the short- and medium-term, retaining supplies of fossil fuels is essential for Japan, but for the long-term, a relationship with these nations that is based on the fossil fuel trade will dissipate. If anything, supposing the age of fossil fuels continues through the twenty-first century and technological advances continue to make unconventional resources less unconventional, Japan might eventually come across that domestic reserve they were hoping for in the 1920s.

With an extensive exclusive economic zone around the archipelago, Japan is already known to have some of the most extensive deposits of methane hydrates in the world. Known as "burning water" (Sawabe 2017, 218), methane hydrates are crystals of 
methane in ice strewn across the ocean floor at the edge of continental shelfs in large quantities (Braun and Glidden 2014, 90). While currently not marketable, Japanese engineers are at the forefront of pursuing techniques to make them a viable source of natural gas (Montgomery 2010,91). Moreover, there is a rush to capture this potential source of energy, because as ocean temperatures rise, methane hydrates are naturally released, and thus, lost as a potential resource (Montgomery 2010, 91). In his message to the public on Marine Day (a national holiday), Abe made specific mention of the potential from methane hydrates:

The plentiful resources provided by [Japan's] vast seas hold great potential. In recent years, there have been mounting expectations towards the development of ocean energy and mineral resources in the waters of Japan that will lead to the creation of new marine industries, including development efforts towards the commercialization of methane hydrates (2017c).

It might not solve the fossil fuel emissions concerns, but it would relieve Japan from its dependency on energy imports, fill the gap left by decommissioned nuclear energy, buy time to accelerate technologies in renewables, stabilize trade imbalances with energy resource supplier states, and have a profound impact on the long-held resource inferiority deeply embedded since 1853 . 
Table 4.1: Japan's Coal Suppliers, 1995 - 2015

(in million tonnes)

\begin{tabular}{|l|l|l|l|l|l|}
\hline & \multicolumn{1}{|c|}{1995} & \multicolumn{1}{c|}{2000} & \multicolumn{1}{c|}{2005} & \multicolumn{1}{c|}{2010} & \multicolumn{1}{c|}{2015} \\
& \multicolumn{1}{c|}{127.1} & \multicolumn{1}{c|}{150.8} & \multicolumn{1}{c|}{180.8} & \multicolumn{1}{c|}{184.6} & \multicolumn{1}{c|}{190.6} \\
\hline 1 & Australia & Australia & Australia & Australia & Australia \\
& $65.3(51.4 \%)$ & $90.2(59.8 \%)$ & $103.7(57.4 \%)$ & $117.5(63.7 \%)$ & $124.0(65.0 \%)$ \\
\hline 2 & Canada & China & Indonesia & Indonesia & Indonesia \\
& $18.2(14.3 \%)$ & $19.3(12.8 \%)$ & $29.4(16.3 \%)$ & $33.8(18.3 \%)$ & $32.6(17.1 \%)$ \\
\hline 3 & U.S.A. & Indonesia & China & Russia & Russia \\
& $10.8(8.5 \%)$ & $14.6(9.7 \%)$ & $24.0(13.3 \%)$ & $10.7(5.8 \%)$ & $16.8(8.8 \%)$ \\
\hline 4 & China & Canada & Russia & Canada & Canada \\
& $10.1(7.9 \%)$ & $13.6(9.0 \%)$ & $10.7(5.9 \%)$ & $10.5(5.7 \%)$ & $8.2(4.3 \%)$ \\
\hline 5 & Indonesia & Russia & Canada & China & U.S.A. \\
& $9.5(7.5 \%)$ & $5.4(3.6 \%)$ & $7.4(4.1 \%)$ & $6.3(3.4 \%)$ & $5.9(3.1 \%)$ \\
\hline 6 & South Africa & U.S.A. & Vietnam & U.S.A. & China \\
& $5.7(4.5 \%)$ & $3.7(2.4 \%)$ & $2.4(1.3 \%)$ & $3.1(1.7 \%)$ & $1.6(0.8 \%)$ \\
\hline 7 & Russia & South Africa & U.S.A. & Vietnam & Vietnam \\
& $5.0(4.0 \%)$ & $1.6(1.0 \%)$ & $2.1(1.2 \%)$ & $1.7(0.9 \%)$ & $0.5(0.2 \%)$ \\
\hline 8 & other & other & other & other & other \\
& $2.5(1.9 \%)$ & $2.4(1.6 \%)$ & $1.2(0.7 \%)$ & $1.0(0.5 \%)$ & $1.0(0.5 \%)$ \\
\hline
\end{tabular}

Sources: Adapted using data from RIST (2004) and JOGMEC (2016). 
Table 4.2: Initial LNG Export Capability (year)

\begin{tabular}{cll}
\hline 1 & U.S.A. (Alaska) & 1969 \\
2 & Libya & 1970 \\
3 & Brunei* & 1973 \\
4 & UAE* & 1977 \\
5 & Algeria & 1978 \\
6 & Indonesia & 1983 \\
7 & Malaysia* & 1983 \\
8 & Australia* & 1989 \\
9 & Qatar* & 1997 \\
10 & Trinidad & 1999 \\
11 & Nigeria & 2000 \\
12 & Oman* & 2000 \\
13 & Egypt & 2005 \\
14 & Eq. Guinea* & 2007 \\
15 & Norway & 2008 \\
16 & Russia (Sakhalin)* & 2009 \\
17 & Yemen & 2009 \\
18 & Peru* & 2010 \\
19 & Algeria & 2013 \\
20 & Angola & 2014 \\
21 & PNG* & 2014 \\
22 & Cameroon & 2017 \\
\hline
\end{tabular}

* Included Japanese corporate owners. 
Table 4.3: Japan's LNG Suppliers, $1995-2015$

(in billions of yen)

\begin{tabular}{|c|c|c|c|c|c|}
\hline & $\begin{array}{l}1995 \\
¥ 753\end{array}$ & $\begin{array}{c}2000 \\
¥ 1,498 \\
\end{array}$ & $\begin{array}{c}2005 \\
¥ 2,166 \\
\end{array}$ & $\begin{array}{c}2010 \\
¥ 3,549\end{array}$ & $\begin{array}{c}2015 \\
¥ 4,545\end{array}$ \\
\hline 1 & $\begin{array}{l}\text { Indonesia } \\
¥ 312(41.4 \%)\end{array}$ & $\begin{array}{l}\text { Indonesia } \\
¥ 541(36.1 \%)\end{array}$ & $\begin{array}{l}\text { Indonesia } \\
¥ 604(27.9 \%)\end{array}$ & $\begin{array}{l}\text { Malaysia } \\
¥ 781(22.0 \%)\end{array}$ & $\begin{array}{l}\text { Australia } \\
¥ 1,047 \text { (23.0\%) }\end{array}$ \\
\hline 2 & $\begin{array}{l}\text { Malaysia } \\
¥ 144(19.1 \%)\end{array}$ & $\begin{array}{l}\text { Malaysia } \\
¥ 290(19.4 \%)\end{array}$ & $\begin{array}{l}\text { Malaysia } \\
¥ 456(21.1 \%)\end{array}$ & $\begin{array}{l}\text { Australia } \\
¥ 705(19.9 \%)\end{array}$ & $\begin{array}{l}\text { Malaysia } \\
¥ 840(18.5 \%)\end{array}$ \\
\hline 3 & $\begin{array}{l}\text { Australia } \\
¥ 121(16.1 \%)\end{array}$ & $\begin{array}{l}\text { Australia } \\
¥ 192(12.8 \%)\end{array}$ & $\begin{array}{l}\text { Australia } \\
¥ 357(16.5 \%)\end{array}$ & $\begin{array}{l}\text { Indonesia } \\
¥ 574(16.2 \%)\end{array}$ & $\begin{array}{l}\text { Qatar } \\
¥ 711(15.6 \%)\end{array}$ \\
\hline 4 & $\begin{array}{l}\text { Brunei } \\
¥ 93(12.3 \%)\end{array}$ & $\begin{array}{l}\text { Qatar } \\
¥ 166(11.1 \%)\end{array}$ & $\begin{array}{l}\text { Qatar } \\
¥ 240(11.1 \%)\end{array}$ & $\begin{array}{l}\text { Qatar } \\
¥ 436(12.3 \%)\end{array}$ & $\begin{array}{l}\text { Russia } \\
¥ 378(8.3 \%)\end{array}$ \\
\hline 5 & $\begin{array}{l}\text { UAE } \\
¥ 62(8.3 \%)\end{array}$ & $\begin{array}{l}\text { Brunei } \\
¥ 147(9.8 \%)\end{array}$ & $\begin{array}{l}\text { Brunei } \\
¥ 204(9.4 \%)\end{array}$ & $\begin{array}{l}\text { Brunei } \\
¥ 338(9.5 \%)\end{array}$ & $\begin{array}{l}\text { Indonesia } \\
¥ 374(8.2 \%)\end{array}$ \\
\hline 6 & $\begin{array}{l}\text { U.S.A. } \\
¥ 21(2.8 \%)\end{array}$ & $\begin{array}{l}\text { UAE } \\
¥ 127(8.5 \%)\end{array}$ & $\begin{array}{l}\text { UAE } \\
¥ 185(8.5 \%)\end{array}$ & $\begin{array}{l}\text { UAE } \\
¥ 272(7.6 \%)\end{array}$ & $\begin{array}{l}\text { UAE } \\
¥ 294(6.5 \%)\end{array}$ \\
\hline 7 & & $\begin{array}{l}\text { U.S.A. } \\
¥ 32(2.1 \%)\end{array}$ & $\begin{array}{l}\text { Oman } \\
¥ 57(2.7 \%)\end{array}$ & $\begin{array}{l}\text { Russia } \\
¥ 239(6.7 \%)\end{array}$ & $\begin{array}{l}\text { Brunei } \\
¥ 238(5.2 \%)\end{array}$ \\
\hline 8 & & $\begin{array}{l}\text { Oman } \\
¥ 4(0.2 \%)\end{array}$ & $\begin{array}{l}\text { U.S.A. } \\
¥ 43(2.0 \%)\end{array}$ & $\begin{array}{l}\text { Oman } \\
¥ 86(2.4 \%)\end{array}$ & $\begin{array}{l}\text { PNG } \\
¥ 220(4.8 \%)\end{array}$ \\
\hline 9 & & & $\begin{array}{l}\text { Egypt } \\
¥ 10(0.4 \%)\end{array}$ & $\begin{array}{l}\text { Egypt } \\
¥ 33(0.9 \%)\end{array}$ & $\begin{array}{l}\text { Nigeria } \\
¥ 204(4.5 \%)\end{array}$ \\
\hline 10 & & & $\begin{array}{l}\text { Trinidad } \\
¥ 7(0.3 \%)\end{array}$ & $\begin{array}{l}\text { U.S.A. } \\
¥ 31(0.9 \%)\end{array}$ & $\begin{array}{l}\text { Oman } \\
¥ 122(2.7 \%) \\
\end{array}$ \\
\hline
\end{tabular}

Source: Japan Customs (2017). 
Table 4.4: Japan's Crude Oil Suppliers, 1995 - 2015

(in billions of yen)

\begin{tabular}{|c|l|l|l|l|l|}
\hline & \multicolumn{1}{|c|}{1995} & \multicolumn{1}{c|}{2000} & \multicolumn{1}{c|}{2005} & \multicolumn{1}{c|}{2010} & \multicolumn{1}{c|}{2015} \\
& \multicolumn{1}{c|}{$¥ 2,902$} & \multicolumn{1}{c|}{$¥ 4,931$} & \multicolumn{1}{c|}{$¥ 9,989$} & \multicolumn{1}{c|}{$¥ 9,756$} & \multicolumn{1}{c|}{$¥ 7,368$} \\
\hline 1 & UAE & UAE & Saudi Arabia & Saudi Arabia & Saudi Arabia \\
& $¥ 791(27.2 \%)$ & $¥ 1,275(25.8 \%)$ & $¥ 3,067(30.7 \%)$ & $¥ 3,035(31.1 \%)$ & $¥ 2,489(33.8 \%)$ \\
\hline 2 & Saudi Arabia & Saudi Arabia & UAE & UAE & UAE \\
& $¥ 669(23.1 \%)$ & $¥ 1,253(25.4 \%)$ & $¥ 2,554(25.6 \%)$ & $¥ 2,045(21.0 \%)$ & $¥ 1,917(26.0 \%)$ \\
\hline 3 & Iran & Iran & Iran & Qatar & Russia \\
& $¥ 251(8.6 \%)$ & $¥ 555(11.3 \%)$ & $¥ 1,224(12.2 \%)$ & $¥ 1,119(11.5 \%)$ & $¥ 639(8.7 \%)$ \\
\hline 4 & Indonesia & Qatar & Qatar & Iran & Qatar \\
& $¥ 235(8.1 \%)$ & $¥ 474(9.6 \%)$ & $¥ 948(9.5 \%)$ & $¥ 949(9.7 \%)$ & $¥ 596(8.1 \%)$ \\
\hline 5 & Qatar & Kuwait & Kuwait & Russia & Kuwait \\
& $¥ 185(6.4 \%)$ & $¥ 411(8.3 \%)$ & $¥ 695(7.0 \%)$ & $¥ 698(7.2 \%)$ & $¥ 534(7.2 \%)$ \\
\hline 6 & Oman & Indonesia & Indonesia & Kuwait & Iran \\
& $¥ 177(6.1 \%)$ & $¥ 247(5.0 \%)$ & $¥ 295(3.0 \%)$ & $¥ 668(6.9 \%)$ & $¥ 340(4.6 \%)$ \\
\hline 7 & Kuwait & Oman & Sudan & Iraq & Indonesia \\
& $¥ 165(5.7 \%)$ & $¥ 210(4.3 \%)$ & $¥ 279(2.8 \%)$ & $¥ 303(3.1 \%)$ & $¥ 168(2.3 \%)$ \\
\hline 8 & China & China & Oman & Oman & Mexico \\
& $¥ 146(5.0 \%)$ & $¥ 111(2.3 \%)$ & $¥ 256(2.6 \%)$ & $¥ 265(2.7 \%)$ & $¥ 111(1.5 \%)$ \\
\hline 9 & Malaysia & Australia & Australia & Indonesia & Iraq \\
& $¥ 65(2.2 \%)$ & $¥ 79(1.6 \%)$ & $¥ 103(1.0 \%)$ & $¥ 234(2.4 \%)$ & $¥ 102(1.4 \%)$ \\
\hline 10 & Vietnam & Iraq & Nigeria & Sudan & Vietnam \\
& $¥ 58(2.0 \%)$ & $¥ 76(1.5 \%)$ & $¥ 85(0.9 \%)$ & $¥ 120(1.2 \%)$ & $¥ 62(0.8 \%)$ \\
\hline
\end{tabular}

Source: Japan Customs (2017). 
Table 4.5: Supplier Relationship with Japan

\begin{tabular}{|c|c|c|c|c|c|c|}
\hline & \multicolumn{2}{|c|}{ Coal } & \multicolumn{2}{|c|}{ LNG } & \multicolumn{2}{|c|}{ Crude Oil } \\
\hline & $\begin{array}{l}\text { Current } \\
\text { Essential } \\
\text { Supplier }\end{array}$ & $\begin{array}{l}\text { Potential } \\
\text { Essential } \\
\text { Supplier }\end{array}$ & $\begin{array}{l}\text { Current } \\
\text { Essential } \\
\text { Supplier }\end{array}$ & $\begin{array}{l}\text { Potential } \\
\text { Essential } \\
\text { Supplier }\end{array}$ & $\begin{array}{l}\text { Current } \\
\text { Essential } \\
\text { Supplier }\end{array}$ & $\begin{array}{l}\text { Potential } \\
\text { Essential } \\
\text { Supplier }\end{array}$ \\
\hline \multicolumn{7}{|c|}{ Southeast Asia } \\
\hline Indonesia & Y & $\mathrm{N}$ & $\mathrm{N}$ & $\mathrm{N}$ & $\mathrm{N}$ & $\mathrm{N}$ \\
\hline Malaysia & $\mathrm{N}$ & $\mathrm{N}$ & Y & $\mathrm{N}$ & $\mathrm{N}$ & $\mathrm{N}$ \\
\hline \multicolumn{7}{|c|}{ Post-Soviet Asia } \\
\hline Kazakhstan & $\mathrm{N}$ & $\mathrm{Y}$ & $\mathrm{N}$ & $\mathrm{N}$ & $\mathrm{N}$ & $\mathrm{Y}$ \\
\hline Turkmenistan & $\mathrm{N}$ & $\mathrm{N}$ & $\mathrm{N}$ & Y & $\mathrm{N}$ & $\mathrm{N}$ \\
\hline \multicolumn{7}{|c|}{ Middle East } \\
\hline Iran & $\mathrm{N}$ & $\mathrm{N}$ & $\mathrm{N}$ & $\mathrm{Y}$ & $\mathrm{N}$ & $\mathrm{Y}$ \\
\hline Iraq & $\mathrm{N}$ & $\mathrm{N}$ & $\mathrm{N}$ & $\mathrm{N}$ & $\mathrm{N}$ & $\mathrm{Y}$ \\
\hline Kuwait & $\mathrm{N}$ & $\mathrm{N}$ & $\mathrm{N}$ & $\mathrm{N}$ & Y & $\mathrm{N}$ \\
\hline Qatar & $\mathrm{N}$ & $\mathrm{N}$ & $\mathrm{Y}$ & $\mathrm{N}$ & $\mathrm{Y}$ & $\mathrm{N}$ \\
\hline Saudi Arabia & $\mathrm{N}$ & $\mathrm{N}$ & $\mathrm{N}$ & $\mathrm{Y}$ & $\mathrm{Y}$ & $\mathrm{N}$ \\
\hline UAE & $\mathrm{N}$ & $\mathrm{N}$ & $\mathrm{Y}$ & $\mathrm{N}$ & $\mathrm{Y}$ & $\mathrm{N}$ \\
\hline
\end{tabular}




\section{CHAPTER V}

\section{ACCESS TO MARKETS}

In the 2015 work The Risk Pivot, Jones and Steven divide the world into three groups based on access to energy. The first group is about 1.3 billion people in rural Africa and rural Asia. This group is unlikely to see much change in their impoverished lifestyles in the twenty-first century. On the other end, another 1.3 billion live in Organization of Economic Cooperation and Development (OECD) countries. These would be the "core," as defined by Immanuel Wallerstein in The Modern World System (1974): the developed world. Surplus income exists for sizable middle classes, as does easy and affordable access to energy, food, potable water, healthcare, education, and technology. This group is mostly in North America, Western Europe, and East Asia, including Japan. The group that lies in between is roughly five billion people. "They live in the rapidly growing cities of the world's poor and middle-income countries" (Jones and Steven 2015, 58). They are urbanizing, communicating, and have high expectations for changes. The mass consumption that comes with a developed country lifestyle is seemingly within their grasp. Moreover, many of these same countries are amid a population explosion.

This group is what will define the twenty-first century. It includes mass populations in Latin America, Sub-Saharan Africa, and China, but importantly, it includes populations throughout Muslim Asia. The average age in majority Muslim countries in Asia is 25 years, while it is 30 in Asia's other countries (Simpfendorfer 2014, 52-53). Young and urban populations informed through the propagation of smartphones are growing throughout these regions. Simpfendorfer points out that "over half of Malaysia's population has a Facebook account, as do one-third of Indonesians and one- 
fifth of Saudi Arabians," and it is certainly more by now (2014: 71). While many of these states are experiencing rapid economic development, shifting into the category of 'newly industrializing economy' (NIE), one of the biggest challenges for these states is meetings the needs of these citizens.

For Japan, there is tremendous potential to actively engage with these markets in Muslim Asia. In a 2015 survey of Japanese investors in Indonesia, the overwhelming reason they chose to locate their operation in Indonesia was the future growth potential of the local market (83.4 percent response) (Ma 2016, 2). What Japan lacks in energy resources, it must make up elsewhere, and historically this has been its human resources, first, then its technology. This has garnered Japan a reputation for quality hightechnology throughout much of the world, but it increasingly faces intense competition notably from American, Chinese, and South Korean companies. With low domestic economic growth, low interest rates, and population decline, Japanese firms must look for growth opportunities overseas. Simpfendorfer estimates consumer spending in Muslim Asia to be around $\$ 2.5$ trillion in 2013, and growing (2014: 71). These markets in Muslim Asia are crucial for Japan to retain not just its economic positioning in the world, but also the inflow of capital needed to sustain the purchase of energy resources imports and retain the state and society's ontological security. "It is natural for Japan...to leave no stone unturned in its quest to win orders for infrastructure projects in the Middle East. However, doing so will require an accurate grasp of the needs of the region" (Yamauchi 2010).

This chapter proceeds with a background view of Japan's export relations with Muslim Asia which frames the fluidity of market-access strategy as it relates to temporal 
factors both domestic and international. This understanding of Japan's strategy to access markets in Muslim Asia is to be considered in tandem with its strategy for access to energy, from the previous chapter. The chapter continues by introducing the Flying Geese Theory, which helps unpack Tokyo's conceptualization and strategy for access to markets in Muslim Asia. It then examines several key industries for FDI and export which reveal the current outcomes of Tokyo's access to markets strategy. The chapter concludes by discerning how and where Islam is considered, and securitized, from the evidence of the reviewed cases.

\section{Background}

After Japan abruptly withdrew from the Namban Trade and the closed-country policy (Sakoku) started in 1635, Japanese products still made their way to Muslim Asia, but were limited to shipment on Dutch or Chinese ships out of Nagasaki. The Dutch ships, specifically, would inevitably leave Nagasaki and stop at Batavia in the Dutch East Indies, populated with Muslim consumers of the Japanese products, and products would occasionally make their way to the Indian subcontinent and Arabian ports. During the Sakoku period, direct economic relations were deliberately constrained by the Tokugawa shogunate, but it is incorrect to believe Japan was not engaged in trade in Asia, and with Muslims during the Sakoku period; Japan took advantage of the transition from Ming to Qing dynasties in the mid- to late seventeenth century which temporarily placed China's export industries in distress, and ramped up much market share for ceramics - becoming a significant exporter to the Persian Gulf region via third-party ships (Frank 1998, 105). South Asia was also a destination for Japanese exports. Ruled by the Mughal Empire, the Mughals opened the subcontinent up to existing maritime trade linkages among Arabs 
and Persians. Frank notes that "the vast bulk of this trade was in Muslim Indian hands and on Indian-built shipping, although some was also in Arab and Southeast Asian - also Muslim - hands" (1998: 88). Bengal was the most productive region within the Mughal Empire, with cotton and silk exports making their way into Japan via southeast Asia, despite the Sakoku policy.

The 1868 Meiji Restoration and rapid modernization of Japan in the late nineteenth century opened it up to export destinations, but by then Muslim Asia was largely restricted by colonialism. In fact, throughout Japan’s Meiji Period (1868-1912), nearly all Muslim Asia was a colony of some empire to the west, namely wide swaths of Central Asia and the Caucasus controlled by the Russians, Arabia and the Levant controlled by the Ottomans, Indonesia controlled by the Dutch, and South Asia as well as all other regions by the British to some degree. Markets were not open, and therefore were of little interest for the Japanese. Nonetheless, some small-scale investment projects took place first in China, then Japanese also began investing in rubber plantations in the Dutch East Indies and British Malaya soon thereafter.

Cotton textiles were a key export industry for Meiji Japan; while the abundance of raw cotton that came from South Asia was monopolized by the cotton manufacturers in the UK, Japan imported its raw cotton mainly from the U.S. By 1900, the British opened up the exports of raw cotton from the Raj to Japan, and the subcontinent soon became Japan's main supplier. By the 1930s, Japan became the largest cotton textile exporter in the world (Conlon 2010). Osaka was called 'the Manchester of Asia,' with dozens of mills throughout the city. Prior to the age of petroleum transforming Japan's economic relations with the Middle East, Japan was actually a net exporter to the Middle East rather 
than importer; cotton textile manufacturers were among the first in Japan seeking markets in the Middle East after the fall of the Ottoman Empire (Enayat 1994, 101). After cotton textiles, small quantities of Japanese goods such as porcelains, lacquer ware, and silk also made their way into Middle Eastern markets in the 1920s. Since Japan was importing hardly anything from the region, it benefitted from a large trade surplus which was used to attain raw materials elsewhere, including South and Southeast Asia.

A highly competitive market in the Middle East during the 1920s was processed cotton imports, dominated by Russian, British, and Indian cotton. In 1931, Japan abandoned the gold standard, and throughout the 1930s was able to obtain a respectable market share by undercutting other suppliers' prices with a depreciated yen (Enayat 1994, 108). By 1933, Japan was the second-greatest exporter of merchandise to Persia after the Soviet Union (Enayat 1994, 108). Japan's cotton exports to Iran remained vibrant throughout the decade, supplying nearly three-quarters of all cotton imports until 1941 when Anglo-Soviet forces invaded Iran and ordered it to cut relations with Japan (Enayat 1994, 110).

At the outbreak of World War II, the cotton textile industry came to a halt. Japan was cut-off from South Asia and the Middle East altogether. Direct relations with South Asian states were not established until 1952, after India and Pakistan gained independence from the British Raj, and Japan's sovereignty was restored. In the 1950s, once again, it was cotton that served as Japan's key export commodity, although Japan's raw cotton imports increasingly came from the U.S., which had provided special loans to Japan for raw cotton. By the 1960s, iron replaced the prewar reimport model with South Asia, as Japan imported Indian iron ore, and exported metal machinery to India made 
from the iron ore. While the Middle East remained a minor export destination globally, quantities of exports to the region increased steadily until the 1970s (Enayat 1994, 119). By then, petrodollars where creating a market for Japanese exports, but were overshadowed by Japan's growing thirst for crude oil.

Postwar, there was a distinct hesitancy in how Southeast Asian Muslims reacted to reestablishing economic relations with Japan, versus Muslims in the Middle East and South Asia. In South Asia and the Middle East, Japan had no legacy of imperialism or aggression, and its rapid development - both prior to the war, and again, after - were seen as admirable. Postwar, Muslim populations in Southeast Asia had reason to be suspicious of Japan's intentions. Initial Japanese FDI projects in the 1950s included minor projects to develop copper mines in Malaya and the Philippines, but these were small-scale enterprises (Mason 1999, 30). The Japanese were able to gradually build trust in Southeast Asia through war reparations agreements, but these came with the deliberate intention to gain access to the markets. ${ }^{1}$

By the late 1960s Japan was becoming a major foreign direct investor, and Muslim Southeast Asia would become a key export market and FDI destination for Japanese companies, particularly Japan's textile manufacturers who began moving operations outside of Japan to Southeast Asia where labor was cheaper and abundant, but not without tension. In January 1974, a student-led anti-Japanese demonstration took place in Jakarta to coincide with the visit of Japanese Prime Minister Tanaka Kakuei, resulting in the deaths of 11 people, and the looting of (among other establishments) a

\footnotetext{
${ }^{1}$ Discussed further in the following chapter.
} 
Toyota dealership. Known as the Malari Incident, undoubtedly what sparked the demonstrations was what protesters call "economic invasion" by Japanese firms, but reflections on the incident show the crux of the grievances was more broad and complex (Ogawa 2016, 183). For one reason, establishments owned by Chinese Indonesians were targeted in the looting. Demonstrators mentioned corruption in Suharto's government, price increases, and a wealth gap between overseas Chinese and native Indonesians among their grievances, which had little to do with Japan. Moreover, it is suspected that Suharto's government was tacitly supporting the demonstrations, as there were concerns also among political elites regarding Japanese business approaches in Indonesia (Ogawa 2016, 185).

For the long-term, the Malari Incident did not slow down Japan's exports and FDI in Southeast Asia, but it did point out the need for better consideration of local conditions, and while not directly related, also led to a more public sense of atonement for the wartime occupation which mobilized the development assistance strategies (Hoshiro 2007). ${ }^{2}$ On his flight back home, Tanaka remarked that "economic bias has caused Japanese in Indonesia to lack understanding of the local culture, and thus, we invited this criticism of Japan” (Ogawa 2016, 187). The Malari Incident was a pivotal moment for Japanese to reevaluate how they operated in overseas environments.

After the postwar occupation, the Japanese government controlled outflows of FDI so that exports of 'made-in-Japan' manufactured goods could most easily find markets, and so that FDI would facilitate for the imports of essential energy resources

\footnotetext{
${ }^{2}$ Discussed further in the following chapter.
} 
(Mason 1999, 29). The expansion of Japan's FDI projects in the late 1960s coincided with Mao's rule in China and Kim Il Sung's rule in North Korea. Meanwhile, South Korea did not allow Japanese FDI until after formal diplomatic relations were established in 1965. Thus, three of Japan's nearest neighbors had blocked their entire markets from the inflow of Japanese FDI. Obstruction of these nearby markets forced Japan to look elsewhere for FDI destinations in Asia, and build ties with several countries in Muslim Asia. In 1969 the government revised its stance on constraining FDI, and in contrast, sought to deliberately liberalize FDI outflows (Mason 1999, 31). The Four Asian Tigers stood out as springboards to destinations in Asia farther afield. These are where Japanese firms experimented with FDI projects, learned, and moved on as these small states industrialized. Throughout the 1970s, Japanese textile manufacturers, electronics manufacturers, and automobile firms moved operations into Asia in increasing numbers (Mason 1999, 31).

The biggest surge of FDI into Muslim Asia happened in the 1990s, as the Four Asian Tigers had industrialized and attained developed-state attributes. Destinations for FDI broadened, yet Muslim Southeast Asia remained a favorite due to resource abundance, plentiful, cheap labor, proximity to Japan, and a favorable political and social environment (Enayat 1994, 143). The timing coincided, however, with the immediate post-bubble economic downturn, and overall Japanese corporations were investing less overseas while the breadth of destinations widened. FDI in developed countries tended to decrease in aggregate numbers since the late 1980s while FDI into developing countries tended to increase during the same period of time (Lakhera 2008, 35). Much of this was due to the fall of the yen relative to the U.S. dollar, as most FDI in the developed 
countries was in the U.S., but simultaneously the fall of the Soviet Union opened the Central Asian republics, which had been sealed off from Japan as an export market for over a century, to FDI as well.

\section{Flying Geese Theory}

To reveal Tokyo's strategy with Islam and Muslim Asia, and how it navigated securitization of these while solidifying and broadening its access to economic markets, Flying Geese Theory (FGT) stands out as both a relevant and suitable theoretical framework. It is relevant because the theorist who developed it was Japanese and had Japan's political-economic relations in mind. It is suitable because the content of the theory may be erroneous and worthy of criticism, but it appears to be emulated in the Arc, and in subsequent language used by Japanese political elites on economic relations in Muslim Asia. It provides a window into Japanese identity, role, and normative purpose in Asia.

FGT is an economic development theory proposed by economist Akamatsu Kaname in the 1930s who observed how Japan had stood out among Asian states in terms of industrialization. Japan was the first Asian state to export manufactured goods, and the first to import machinery and raw materials. This particularity was a source of pride in Japan, and its academic world as well. As seen in Figure 5.1, the first dimension to FGT is the transitional progression of Japan's economy from an agrarian, to textile manufacturing, to machinery-based, as firms increasingly collect profits and find means to relocate manufacturing to cheaper labor while retaining sections such as research and development $(\mathrm{R} \& \mathrm{D})$ at home that push to develop more advanced, less replicable 
products (Sun 2017, 26). The process is then repeated in a new, more advanced sector of the economy.

The second dimension is the relationship with other Asian economies, which is not vertical, such as the suzerain and the colony, and is not horizontal, as in trade among European states. Rather, as seen in Figure 5.2, the lower-stage sector base would be 'passed on,' or relocated to the next country, and as this state industrializes, it moves on once again to another country, and thus all states in a region would progress together in the V-form like flying geese. As explained by Lakhera:

Following shortly after the Japanese economy's decade of rapid economic development during the 1970s and 1980s, the Asian economies...have emerged from the pack of developing countries to what one may call the 'miracle' of economic growth. The Japanese MNEs, in particular, implemented the transfer of their technologies to the host countries through FDI. This generated an FDI-led sequential process of economic development also referred to as 'staged development' or 'tandem growth' paradigm and so forth. Greatly facilitated by Japanese FDI, changes in the industrial restructuring and trade flows, has enabled the countries of this region to move upward on the ladder of industrialization while maintaining international division of labor (2008: xiii-xiv).

There is some evidence to support FGT: "an analysis of 148 countries shows that as GDP rises, manufacturers within each country predictably move toward making ever more complicated products" (Sun 2017, 26). Encarnation agrees, but also notes the side effect of post-development domestically in Japan:

By weaving...FDI, trade, and technology flows into cross-border networks, Japanese multinationals have fundamentally reorganized production across Asia. Thus, they have been linked both to the "hollowing out" back home of the Japanese economy, and to the "economic miracle" visible in those Asian economies hosting Japanese FDI (1999: 3).

The theory was largely forgotten during World War II when Japan was constructing vertical, suzerain-style relationships in colonies and not the FGT model, but 
just as Japan has reindustrialized and surpassed the development achieved prior to the war, FGT was revived in academic circles in Japan in the 1960s. Raymond Vernon introduced it to the Anglophone world in 1966 when he developed a comparable theory, the Product Life-Cycle Theory. FGT received recognition once again in 1985 when economist and politician Ōkita Saburō argued that the second stage of the theory was actively taking place in Asia, with the rise of the Four Asian Tiger economies. By this point, Japan had high-technological electronics and automobiles. The Four Asian Tigers were transitioning from textiles to machinery, and were just making inroads into electronics. Indeed, by the 1990s the pattern of development in Asia could be said to have followed along Akamatsu's FGT, as Lakhera describes, “Japan is seen as the first-tier industrial power, with the NIEs as the second tier and the ASEAN countries of Thailand, Malaysia, Indonesia, and Philippines as the third tier" (2008: 47).

FGT has undoubtedly received criticisms. As presented by Akamatsu, it has little to offer in terms of why technology transfer is assumed to occur, or how so. It does not account for the fact Japan allowed (and continues to allow) substantially little FDI in its own economy, especially in comparison to subsequent developing states in the model. It also quickly loses its luster when contemporary conditions do not suit the theory, such as during World War II or the 1997 Asian financial crisis. Nevertheless, an argument can be made that the theory has played out beyond what Akamatsu initially modeled. Japan passed through the stages, followed next by the Four Asian Tigers, then the Tiger Cub economies in Southeast Asia which are still in the catch-up period, and China, although the sheer size of China's economy makes it more challenging to fit into the model (Lakhera 2008, xiii). Beyond these are the 'Latecomers' and 'Latest Comers' in South 
Asia (minus Afghanistan) as well as Central Asia - still dependent on raw materials as the key industries, although like China, the sheer size of India's economy makes it more challenging to classify. The terms used here, Four Asian Tigers, Tiger Cubs, Latecomers, and Latest Comers are not from Akamatsu, but rather more recent terms to categorize countries as they progress through the model. Akamatsu did account for a period of decline, which one could argue is the position of Japan now, where domestic manufacturing declines, domestic market retracts, and imports decline as well.

Throughout the Edo Period and most of the Meiji Period up to the twentieth century, Japan's trade was exporting raw materials, namely copper, silver, coal, raw silk, and tea, and importing manufactured goods, such as textiles, iron, and rails, and increasingly machinery was also imported. Japan's comparative advantage was natural resource-intensive commodities and its disadvantage was capital-intensive technologically advanced commodities. After the military victories in the First SinoJapanese War and the Russo-Japanese War, as well as vast population growth and increases in living standards at the start of the twentieth century, strains on Japan's natural resources were already being felt and the government took a more active role in transitioning the export industries. By 1930, the trade structure had flipped, with most exports being manufactured goods such as cotton and silk textiles, processed sugar, wheat flour and pottery, and most imports being natural resource commodities, such as raw cotton, sugarcane, lumber, crude oil and coal. This is precisely when Akamatsu identified Japan being in stage one of FGT model.

From this point, driven by military interests, Japan transitioned its economy once again to the development of heavy machinery industries, but not for export. 
Inadvertently, this would transition Japan to the following stage in an incomplete and unsustainable manner. Trade deteriorated, as did domestic supplies of natural resources, which fed into the need to appropriate the natural resources in territories abroad. In the immediate postwar era, the government attempted to utilize the technological know-how attained from the heavy machinery industry during the war and shift it to a key export industry. It was the textile industries which initially picked up with postwar exports, mostly to destinations in Asia, but the transition to the next stage was already being planned (Yamawaki 2007, 12). Despite the initial shortages in capital, exports of iron and steel, shipbuilding, transportation machinery, and chemical fertilizers grew rapidly, fed by the desire for such products in the U.S. and the outbreak of the Korean War. Japan's main export market shifted from Asia to the U.S. (Yamawaki 2007, 12). Increased domestic affluence in the 1960s and 1970s created a demand for appliances and electronics, and the industrial transition took place toward monochrome televisions, washing machines, and refrigerators. The transition also illustrated a shift from cheap, unskilled labor-intensive products to high-technological, capital-intensive products. The fertilizer chemical industry also transitioned to a petro-chemical and fine chemical industry. Meanwhile, increased affluence meant higher wages, which contracted the size of the labor-intensive textile industries. These industries were being picked up by the Four Asian Tigers. When product quality and international competitiveness improved, Japanese industry transitioned once again to color televisions, air-conditioners, office machines, instruments, and automobiles.

The experiences of development, resource endowments, social and cultural makeup, as well as exogenous demand for exports vary for all states. For example, Japan 
could not have transitioned so quickly in the immediate postwar era from textiles to machinery without the demand for such products by American civilian consumers and the U.S. military in Korea, nor would Japan have been able to do so without the wartime knowhow that was attained due to militarization. The Four Asian Tigers undoubtedly learned from the Japanese experience, and indeed, South Korea and Taiwan deliberately emulated the model in many respects, but time, natural and human resource endowments, business culture, and international demand and competitiveness were all significant variables in the successful development experience. The Four Asian Tigers did, however, undoubtedly benefit from Japanese investment, as explained by the FGT (Lakhera 2008, xiii).

Akamatsu's theorizing has a tremendous impact on Japan's thinking of Asia today. ${ }^{3}$ Portions of the model were played out prophetically, which garnered recognition. More importantly, however, it provides an academic justification for underlying nationalistic tendencies in Japanese society, and supports a key hypothesis of this project, that Japan's self-perceived role in Asia is one of being on stage, and not among the crowd. On the other hand, however, it relates Japan to Asia, as the 'escort-runner' Asō Tarō analogized. FGT is dynamic in ways vertical or horizontal economic relations cannot be, and therefore, allows for modeling, cooperating, and collective sense of development. This can be seen as the basis of how Japan views economic relations with Asia, and germane here, Muslim Asia.

\footnotetext{
${ }^{3}$ It also raises the question of whether China's current "win-win" development claims are modeled on or echo Japan's FGT.
} 


\section{Overseas Markets for Key Industries}

There is tremendous potential for Japanese exports into Muslim Asia, mostly as a result of FDI, but some by direct exports as well. Malaysia and Indonesia both imported over $\$ 11$ billion in 2016 , followed by UAE at nearly $\$ 8$ billion, and Saudi Arabia at $\$ 5$ billion (see Tables 5.1 and 5.2). Globally, Japan's biggest exports are automobiles (22 percent of total), machinery (19.2 percent), electrical machinery (15.2 percent). In notable decline in recent years is shipbuilding, which fell 42.4 percent from 2012 to 2016 . This section reviews Japan's key export product groups to Muslim Asia in order to develop a typology of product trends and export markets. Product groups examined include automobiles (new and used), which remains the cornerstone of Japan's export economy; consumer electronics and shipbuilding, both of which have been very important to Japan's export economy; high-speed rail and nuclear energy technology, both of which are relatively new export industries and ones with steep competition; and lastly, the broader services sector which may be the trend in future years.

New Automobiles (and Automotive Parts)

Indonesia is the most vibrant automobile market in Muslim Asia. Not only does it have the second largest number of sales of new vehicles in 2016 in Muslim Asia surpassing 1 million vehicles, but sales in 2016 were over three times those in 2006 (see Table 5.3). Moreover, the market share of just five Japanese brands comprises over 90 percent of all sales in Indonesia (Nikkei 2017). Called "the backyard of Japanese carmakers," Japanese auto makers have deeply cornered a burgeoning market, with several factories and distributors throughout the country. In Malaysia, which is the fifth-largest market in Muslim Asia, Japanese brand vehicles have long dominated the market since 
the late 1960s, although through long-term government planning, technology transfer allowed for the designing, engineering, and manufacturing of Proton and Perodua automobiles in Malaysia. These two national auto brands control 48 percent of the market share in Malaysia, but collectively Japanese brands occupy 42 percent of the market, leaving very little room for other foreign brands (Tan 2017).

Japanese brands dominating market share is hardly the scenario in Muslim Asia's largest automobile market: Iran. Iran had a history of a vibrant auto manufacturing industry prior to the Islamic Revolution, but it has been set back for two decades. By the twenty-first century, it has revived, albeit, with inconsistent unit production growth on account of U.S.-led economic sanctions (Financial Tribune 2016). Today, auto production is the second-biggest sector in the economy after oil and gas production (Financial Tribune 2016). In 2016, nearly a million and a half new automobiles were sold in Iran, and most of these were produced domestically by Iran Khodro or SAIPA - two state-owned auto manufactures that hold 90 percent of the market share (Financial Tribune 2016: OICA 2018). Tehran aims to increase auto production to 3 million vehicles by 2025 , producing enough to supply a growing domestic demand as well as supply growing demand in neighboring Iraq and Afghanistan as well (Financial Tribune 2016).

To do this, joint ventures are necessary, and Iran Khodro, SAIPA, as well as Iran's smaller private auto manufacturers have worked together with Japanese auto makers in the past. Bahman, for example, is a private auto maker that worked together with Mazda as early as 1959, and tends to seek joint ventures specifically with Japanese auto makers (Financial Tribune 2016). After the Iran Nuclear Accord was signed, Japanese auto makers have been slow to reinvest in Iran, with European companies 
jumping to take up joint venture opportunities. "Japanese automakers seem to be slow in responding, due partly to such factors as lingering uncertainty over domestic politics and US financial sanctions still being in place" (Financial Tribune 2016). JETRO officials note that Iran has the demographic makeup and bedrock know-how of the automobile industry to serve as a regional springboard for Japanese auto models, much as Indonesia does in Southeast Asia, yet it is losing out as time progresses (Financial Tribune 2016). Among completed auto imports, Japanese brands made up less than a fifth of what arrives in Iran.

Muslim Asia's third largest market by new auto sales is Turkey, where in 2016 over a million units were sold (OICA 2018). The Marmara region in Turkey has emerged as a significant auto manufacturing region, yet burgeoning domestic demand as well as proximity to Europe has resulted in nearly three quarters of Turkey's new automobile sales being imported finished products in 2015 , notably all Volkswagen units, and nearly half of the Ford and Renault units (Bufton 2016). Japanese brands differ from this trend. With such proximity to both a growing market in a newly industrialized economy, and sustained demand in Europe, competition among auto manufacturers has been intense in Turkey, resulting in Japanese brands holding a relatively modest, consistent portion of the market share, yet a much higher proportion of domestically produced vehicles. In 1994, Toyota was the first Asian auto manufacturer to open a plant in Turkey, and exports from Turkey to neighboring regions started in 2002 (Roberts 2014). Collectively, Japanese auto manufacturers occupy no more than a tenth of the market share in Turkey for 2013 (Tuzmen 2013). Toyota, in particular, has sought to strengthen its domestic 
manufacturing, which accounts for nearly a third of all automobiles produced in Turkey, and is second only to the Turkish brand, TOFAȘ (Daily Sabah 2016).

Several other major automobile markets exist in Muslim Asia, but more importantly, demand for automobiles is expanding. Saudi Arabia is the fourth largest market in Muslim Asia in new car sales with 655,500 units sold in 2016 (down from 830,100 in 2015). When in October 2017 King Salman decreed women would be allowed to drive, Toyota responded by tweeting an advertisement of a woman in an abaya smiling just as she is entering the driver's seat of a blue Toyota (Parasie and Stancati 2017). Toyota and Nissan control nearly 40 percent of the market in Saudi Arabia, and have much to gain with women now driving (Parasie and Stancati 2017).

Japanese automobile makers first gained a foothold in the Middle East market in the late 1970s with the Toyota Land Cruiser, nicknamed "alam n japonais" ("the Japanese camel'). Particularly 1980s models were noted for their affordability and a reliable engine in desert and off-road environments, Land Cruisers have been "integrated into the cultural logic" and "attain an importance that goes beyond their daily work" (Scholze 2010, 184). The market for Toyota Land Cruisers as well as the Hilux, another Toyota truck, in the Middle East never received much global notoriety until 2014 when media disseminated images of ISIS from Syria and Iraq. Conspicuous in these images were the multitude of ever-present Toyota trucks being driven by ISIS members. "In nearly every ISIS video, they show a fleet - a convey of Toyota vehicles" (Wallace 2015). The Toyota trucks, including the Land Cruiser and the Hilux, were so pervasive, the U.S. asked the Toyota Corporation in 2015 to investigate. In fact, Toyota trucks have been so common with extremist groups, they have been called "the vehicular equivalent 
of the AK-47" (Finlan 2015). From Japan, the head office of Toyota stated "[i]t is impossible for any automaker to control indirect or illegal channels through which our vehicles could be misappropriated, stolen or resold," adding "Toyota has a strict policy to not sell vehicles to potential purchasers who may use or modify them for paramilitary or terrorist activities" (Greimel 2015). ISIS and other militants likely gain access to most of their Toyota trucks smuggled by middlemen into the country, and paid for by sympathizers (Engel 2015: Greimel 2015).

\section{Used Automobiles (and Automotive Parts)}

Fukuda and Asazuma (2011) build on a concept proposed by Togawa (1998) whereby Japan's auto manufacturing industry works as an "artery" while the used car market is a "vein," in which "each can never be thought of detached from the other" (2011: 163). Alongside the 'artery' - the new Japanese brand automobiles sold throughout Muslim Asia, there is also a 'vein' - a vibrant market for used Japanese brand automobiles exported directly from Japan to Muslim Asian countries. Beyond automobiles being a key cornerstone to Japan's export economy, Japan could also be considered "the world-leading major power of used car exports" (Fukuda and Asazuma $2011,163)$. There are notable push-pull factors. The push is the biannual vehicle inspection, or shaken, required for all full-sized automobiles in Japan beginning with the auto's third year. As vehicles age, shaken becomes increasingly expensive, often in the range of $\$ 1,000$ to $\$ 2,500$ each time, incentivizing Japanese drivers to replace their aging vehicles, despite that fact most vehicles are still capable of performing for another 100,000 miles or more. Many of these vehicles are exported. The stringent inspection system is to ensure a high quality of vehicles on the roads and to curtail carbon emissions 
at a reliable rate, but it also supports the domestic sales of new Japanese brand automobiles (Brooks 2011, 4).

The pull factor is that in several Muslim Asian countries, Japanese vehicles are well reputed, but without a domestic assembly plant or sufficient plants to satisfy domestic demand, they remain unattainably expensive as complete-unit imports (Fukuda and Asazuma 2011, 188). Thus, a vibrant gray market exists that ties Japan to Muslim Asia. It is not unusual for imported used autos from Japan to retain the markings of the previous owner. In remote parts of Pakistan or Afghanistan the name of a previous owner's establishment can be seen on the vehicle door, written in Japanese. According to Miyata, "That has become a status symbol for them" (2016: 55).

Muslim Asia countries in Southeast Asia and South Asia are important destinations for used Japanese cars not only because of proximity, which lowers shipping costs, but also because, like Japan, all countries in these regions use left-hand traffic vehicles. There are no more than 15,000 Pakistanis in Japan, but many have been involved in the used automobile export market since the 1980s (Rahman and Lian 2011, 265: Brooks 2011, 4). Initially, Pakistanis were only interested in exporting used automobiles to Pakistan, as demand for Japanese brand vehicles in Pakistan was very high, and sharing left-hand traffic, Japanese used vehicles were road-ready in Pakistan with few alterations. Islamabad has since applied import restrictions (Brooks 2011, 4), but Pakistanis in Japan's used auto export market shifted to exporting elsewhere and retained their 'ethnic business' niche in the domestic economy (Fukuda and Asauma 2011, 164). Rahman and Lian point out that for Pakistanis in Japan, 
One advantage to getting into the used car business is that only minimum venture capital is required so long as the right buyer from the other country is found. Furthermore, the whole official procedure from buying to shipment in Japan can be completed online. What is necessary to run this business is to be familiar with the formalities involved in the online transaction (2011: 264).

Brooks notes that Pakistanis in Japan "are longstanding clients of Japanese car merchants who have used their specialist skills and knowledge to link Japanese exports" all around the Indian Ocean rim (2011: 4). Many of these Pakistani residents in Japan marry Japanese spouses, and raise children, which is the source of how many Japanese nationals who are Muslims came to the religion (Fukuda 2015, 45). More recently, more Bangladeshi residents in Japan have also joined in the used auto export market (Rahman and Lian 2011, 265).

Meanwhile, the UAE has also emerged as the key entrepôt in this trade network. To avoid the import restrictions on autos from Japan in countries such as Pakistan, used autos are often reexported through UAE (Fukuda and Asauma 2011, 164). Japan-resident Pakistanis and Bangladeshis often use family networks in UAE to sell used automobiles imported from Japan (Fukuda 2015, 38). In the last three decades, tens of thousands of used busses, commercial trucks, and automobiles from Japan have entered UAE annually, where many are sold in low-income countries in Africa and Central Asia (Fukuda and Asauma 2011, 169).

\section{Consumer Electronics}

Japan once had the largest consumer electronics industry in the world, yet for the last two decades the market share of Japanese brands in consumer electronics has fallen sharply. Part of this is due to increased competition from American, South Korean, and Chinese makers, but secondly, it has been due to a technological shift in consumer 
electronics from electrical machines, such as televisions, radios, and VCRs (mechanical devices with electronic components), to digital devices, such as mp3 players, smartphones, and smart-TVs. While initially Japanese electronics manufacturing was strictly conducted at home, FDI gradually opened up first to the U.S. in the 1980s, then shifting to Southeast Asia. Today, several Japanese brands have consolidated and/or shed their consumer electronics divisions to focus on more profitable core sectors, such as heavy engineering, optical instruments, and robotics.

Japanese-brand mobile phones had the more advanced technology throughout the 1990s and early 2000s, but catered directly to a robust domestic market. According to Pesek, "brisk sales at home fed complacency" (2014: 128). In 2007 when Apple released its first iPhone, Japanese producers had no response. Today in Japan there are more mobile phones in use than there are people in the country, and the domestic mobile phone market is shrinking together with population decline, but the market share occupied by Apple and Samsung surges on the home turf of Japanese electronics producers. Even Sony, the company that introduced the transistor radio, the Trinitron TV, and the Walkman, and led Japan's postwar economic miracle, has not made a serious attempt to compete with a revolutionary innovation in the last two decades. In recent years, Sony has been making more profit from its life insurance policy sales than electronics sales, but after years of net losses, in 2018 Sony was able to regain substantial profits by focusing on its motion picture unit, game software, and supplying image sensors for Apple's iPhones (Mochizuki 2018, B2). It is also looking to regrow by joining in the development of autonomous driving vehicle technologies (Mochizuki 2018, B2). 
This transition of Japan's electronics industry has been difficult, but it also opens up a new path for export markets in Muslim Asia. Japan is to be a "brain country" ( $B B C$ 2013). Nakanishi Hiroaki, president of Hitachi Corporation, made the unusual decision to sell off consumer electronics divisions of the company, and focus on heavy engineering specifically, turbines, nuclear power plants, and high-speed rail (Economist 2015, 53). Nakanishi notes on the market in the developing world: "In developing countries they don't have specific planning and construction know-how [for big infrastructure projects], but we have," adding, "[i]t is not simply a case of selling machinery, but also the engineering, planning, even sometimes the financing of a project. That total process, that is our most important advantage" (BBC 2013).

Most consumer electronics including mobile phones, PCs, and TVs purchased in Muslim Asia are not Japanese brands. The famous Japanese consumer electronics brands, however, like Hitachi, Sony, Panasonic, Toshiba, Fujitsu, and Sharp (now majorityowned by Taiwanese Foxconn) are all shifting operational focus by dropping units that develop consumer-direct products and directly compete with Apple, Samsung, and Huawei, and reinforcing technological advances in home energy-efficiency, electric and hybrid vehicle batteries, heavy-industries, and even agrotechnology. They are also diversifying from each other, thus loosening a clogged competitive market. This diminishes the widespread brand-name recognition, but this is insignificant considering that the consumer electronics market is currently so competitive that brand-name recognition is hardly enough to justify high profit margins (Economist 2014, 57). Given that smartphone sales have stagnated at around 6.5 billion units in recent years, with over 90 percent of global sales being replacements, there is practically no room for growth. 
The growth in electronics is in other, specialized units, namely automotive electronic components (Hoshi 2017). There is tremendous opportunity in Muslim Asia with the refocus by these Japanese brands. Panasonic's CEO, Tsuga Kazuhiro, has outlined a plan for the company to "serve emerging Asian markets better" (Economist 2014, 57).

\section{Shipbuilding}

Japan has dominated the shipbuilding industry since the 1960s, but began losing significant market share to China and South Korea in the last decade. Since 2016, the competitive shipbuilding industry has seen a sharp decline in orders and a glut of suppliers primarily in China, South Korea, and Japan. Chinese companies are gaining market share, even if losing profit, by undercutting production costs in South Korea and Japan. South Korea allowed one of its largest shipbuilders, STX Offshore \& Shipbuilding, to collapse in 2016, but another shipbuilder, Hyundai Heavy Industries has been able to pick up and retain substantial market share (Willumsen and Tutturen 2014).

Iran has two shipping giants, IRISL and NITC, but both have sought contracts with China's shipbuilders to expand their fleets, as well as with Chinese banks to finance the projects (Paris 2015). For the Iranians, China is the safest option among the three East Asia shipbuilding suppliers that can operate outside of U.S.-led sanctions, and South Korea is second to that. An adviser to the China Development Bank points out, "Chinese banks never stopped doing business with Iran and Iranian orders can be the next big thing for Chinese yards" (Paris 2015). IRISL has increased orders from Hyundai Heavy Industries (Shaw-Smith 2016). In Saudi Arabia, the oil tanker fleet had long been entirely made up of Toyota ships (Miyata 2016, 56), but in 2015 Aramco's exclusive shipper, Bahri, placed an order of five tankers also from Hyundai Heavy Industries (Reuters 
2015). Japanese shipbuilders are clearly losing out on shipbuilding contracts in Asia, but this is partially because they are more focused on supplying their own domestic market certainly more than South Korea, and somewhat more than China. Japan is one of the largest ship-owning countries in the world, and maritime transport companies like Mitsui O.S.K. Lines, Nippon Yusen, and K Line are the essential clients for Japanese shipbuilders today, as is the Maritime Self-Defense Force - according to many, the most well equipped 'navy' in Asia (Mizokami 2016).

In Japan, shipbuilding companies have gone through mergers and are attempting to survive through R\&D of lower fuel efficiency ships, and technologically-advanced vessels equipped for utilizing new sea routes such as the Arctic. In August 2016, Japan's four largest shipbuilders announced operational cooperation to create an 'Eco Ship' corner to the market. In 2013, the International Maritime Organization announced a mandatory Energy Efficiency Design Index (EEDI) for all vessels, which requires all ships built in 2025 to be 30 percent more fuel efficient than those built a decade prior. This is a major opportunity for Japan's shipbuilders, which were in decline in both market share and total profits over the last quarter century. Japan also has already dominated with shipbuilding $R \& D$, technologically-advanced ships, and the construction of floating production storage and offloading (FPSO) vessels and LNG tanker technology (Willumsen and Tutturen 2014). It also gives Japan's shipbuilders an opportunity to divert from the acute competition with China and South Korea for low-margin bulk carriers. 


\section{High-Speed Rail}

Japan has been engaging in an intense competition with China to sell its highspeed rail (HSR) technology abroad. Chinese President Xi Jinping and Japanese Prime Minister Abe have campaigned on behalf of their HSR technology on visits across Asia. Japan's HSR model, the shinkansen, was a breakthrough in transportation technology in the 1960s. In 1964, the shinkansen was the first HSR line open to passenger transport. An extensive network of shinkansen tracks has been laid across the country, and despite its proliferation, the shinkansen has an impeccable safety record, with not a single fatal accident, as well as notoriety for their punctuality. Japan retained the highest annual passenger ridership of HSR until 2011, when China's HSR network surpassed Japan's in ridership. China unleashed its first passenger HSR line only in 2008, yet it took just three years before the first fatal accident, when in July 2011, 30 passengers died and nearly 300 were injured (Wendy Wu 2016). In spite of the fatal accident, China continues to expand its HSR network and refine its technology to a standard which can be replicable and sold to foreign markets.

The first overseas sale of Japan's shinkansen technology was in December 1999, when Kawasaki Heavy Industries was selected by the Taiwanese government for its HSR project after controversy arose over the initial selection, a French-German Eurotrain design. The second export of Japan's shinkansen technology was, ironically enough, to China Railways in October 2004 for the CRH2 project, constructed by Kawasaki Heavy Industries, Mitsubishi Electric Corporation, and Hitachi. While China's clear intentions with creating the joint venture was for technology transfer, many in Japan and affiliated 
with Japan's HSR industry have lamented the technology "has now been effectively copied by the Chinese" (Herman 2015).

In Indonesia, Japan and China engaged in a high-key bidding war that mirrored the geopolitical rivalry between the two countries. Noting similarities between Honshu and Java in size, topography, seismology, and population density, Japan had been attempting to sell its shinkansen technology to Indonesia since 2008. Moreover, Indonesia had long been using Japanese second-hand conventional railroad cars, and in 2013 made a large purchase of 180 used railroad cars in an onerous transfer (Miyata 2014a, 63), and remains the top destination for exports of used Japanese railcars (Miyata 2017, 117). In 2009 Japan carried out, and funded its own feasibility study for HSR, and the 150-kilometer project spanning Java seemed to be a shoe-in, but in April 2015 China came in with a counteroffer. In September, Jakarta drew attention when it, first, announced the planned project was cancelled, then just over a week later, announced it had selected China’s \$5.5 billion bid. Japan's Chief Cabinet Secretary, Suga Yoshihide lamented that "large infrastructure projects should be implemented fairly and transparently, taking feasibility into account” (Obe 2015). According to Indonesian officials, China's bid was selected over Japan's because it did not require loan guarantees from Indonesia. Beijing was more willing to accept financial risks associated with the project than Tokyo, or for that matter, Jakarta, itself.

It is estimated China can undercut Japanese and German HSR technology by as much as a third, and can construct lines in half the time (Wendy Wu 2016). A researcher at the Center for China and Globalization opinions that "Japan is more cautious and cares more about the profitability of overseas high-speed railway projects. China, sometimes, is 
willing to tolerate a certain amount of economic losses on projects that have symbolic significance" (Wendy Wu 2016). According to economist Ohno Kenichi, in head-to-head bids Japan will almost always be undercut by China in costs, and he in fact recommends "Japan should shift away from building plants and railways, and toward building human capital such as through education" (Obe 2015).

In December 2015, Japan made up for its loss in Java by landing a $\$ 17$ billion shinkansen deal with India to construct a 508-kilometer line from Mumbai to Ahmedabad. India has several hundred kilometers of other lines planned for the next decade, and Japanese and Chinese companies are eager to supply these. The next battleground between China and Japan is a proposed 350-kilometer transnational line from Kuala Lumpur to Singapore. Bids are estimated to be in the range of $\$ 12.5$ to $\$ 16.2$ billion (Jaipragas 2017).

Bangladesh is also proposing a 200-kilometer, \$4 billion line. In October 2016, the Japanese Ambassador to Bangladesh indicated that Japan was interested in investing in the project, but a year later China proposed a government-to-government agreement to supply the HSR line (Mamun 2017). An official from the Central Bank of Bangladesh stated, “[i]n a developing country like Bangladesh, we often prefer buying Japanese products and durables" (Wendy Wu 2016). He added, "The most pressing reason is Japan's high-quality control and constant pursuit of excellence” (Wendy Wu 2016). Another advantage Japan has is experience working in mountainous topographics, and thus building bridges and tunnels essential for line completion. A Chinese locomotive manufacturer supports this: "China is a country with vast land, so we can always find a suitable place to build railways" (Huang 2017). Huang points out that "Not blessed with 
enough flatlands, countries like mountainous Southeast Asian nations struggle to do so (Huang 2017). Japan has acquired more civil-engineering experience managing this terrain, while China has often taken advantage of the option to route around it.

Further afield in Muslim Asia, more states are seeking HSR investment and technology. Qatar proposed a line linking it to Saudi Arabia and Bahrain in time for the 2022 FIFA World Cup. UAE is also seeking to connect Dubai and Abu Dhabi.

Kazakhstan is seeking to link its capital city, Astana, to its largest city and economic core, Almaty, over a thousand kilometers away. Iran has already contracted with China to construct its first line from Tehran to Isfahan, but more lines are planned. Turkey’s first line, also a China project, linking Ankara to Istanbul, is already in operation.

\section{Nuclear Energy Technology}

Demand for nuclear power plants is surging across Muslim Asia, and it coincides with a new desire by the Japanese government and corporations to export nuclear energy technology. In December 2009, Japan lost a bid to sell nuclear power reactors to the UAE to a South Korean consortium (Yamauchi 2010). While likely not the clincher in the deal, South Korea (as well as France) added a peripheral package in their bid of arms exports and military cooperation, which was something Japan could not offer due to the constraints of a normatively-motivated arms exports ban (Yamauchi 2010). "The UAE apparently favored South Korea because of its willingness to provide military technology and training programs as well as unmanned aerial vehicles and electromagnetic pulse bombs under a bilateral military cooperation agreement” (Yamauchi 2010).

\footnotetext{
${ }^{4}$ The arms exports ban was eventually lifted in April 2014.
} 
Japan was able to wrestle back in Turkey. In March 2010, a Korean company negotiated for a contract to build four reactors at a plant on the Black Sea coast in Sinop, but was not able to come to an agreement. In December, Toshiba and Tepco stepped in to carry out the project, yet talks were suspended three months later when the disaster at Tepco's plant in Fukushima occurred. In October 2013, after Abe came to power and actively assisted in negotiations, Mitsubishi Heavy Industries and Itochu acquired the contract in consortium with French Areva. The deal, worth $\$ 22$ billion, was the first achieved after the Fukushima incident. When completed, it will be Turkey's second nuclear power plant added to the grid (WNA 2018). Interestingly, Turkish leaders cited shared seismic vulnerability with Japan as a factor why they chose to contract with Japanese companies (Corben 2017). For this reason, the project carries great risks, among them Japan's reputation in nuclear technology in the post-Fukushima era.

After the two hydrogen explosions at Fukushima Daiichi Nuclear Power Plant in March 2011, Japan initially decommissioned all of its nuclear power plants, and less than a handful of the plants are currently operating. Yet, amid a strong anti-nuclear power movement at home, Abe has taken the lead in promoting Japanese nuclear infrastructure and technology exports abroad, particularly in Muslim Asia. As if oblivious to the irony, in May 2013 Abe stated at King Abdulaziz University in Saudi Arabia, "Japan can provide renewable energy and the world's safest technology to generate nuclear power" (Kyodo News International 2013). Cultivating the geocultural bonds, Abe added that Japanese technicians in Saudi Arabia will "learn a lot from Islam's spirit of tolerance" (Kyodo News International 2013). Despite losing the deal with UAE to South Korea, Abe still pressed for cooperation with UAE in further nuclear power developments. 
The irony in pushing nuclear infrastructure and technology exports in the postFukushima era cannot be lost on Abe and his administration. Tanami points this out: "Assuming the day comes where not even one nuclear power plant is operating in Japan, and Japanese firms maintain nuclear energy technology by building their market overseas, then it is not a true abandoning of nuclear energy" (2011: 99). Japan was, indeed, a leader in nuclear energy technology, but with most reactors decommissioned, and no prospects of new reactors, and a public deeply resistant to nuclear power, there is no means to advance a competitive edge in nuclear energy technology. Nonetheless, for the time being, domestic nuclear energy manufacturers have substantial investments in nuclear energy technology, and now must look overseas for survival (Japan News 2016, 3). The Abe administration has taken upon itself to promote its nuclear technology for export, focusing on Turkey, India, Kazakhstan, Jordan, Saudi Arabia, and UAE, yet it faces intense competition from firms in South Korea, France, China, and Russia.

In Kazakhstan, the government has been considering using one of two locations as possible sites for the first nuclear power plant to be built since the Soviet plant at Aktau (Shevchenko) closed in 1999. The first was Kurchatov, near the Soviet Nuclear Test Site at Semipalatinsk, and the second at Ulken, on the bank of Lake Balkhash. Russia's Rosatom has offered to construct a VBER plant at Kurchatov. Meanwhile, Westinghouse's AP1000 plant was designed by Toshiba for Ulken. In January 2015, Kazakhstan agreed to the Rosatom VBER plant at Kurchatov, but also indicated it was still interested in the AP1000 at Ulken as a second plant.

Westinghouse was owned by Japanese firms Toshiba (87 percent) and IHI Corporation (three percent), and the Kazakhstani firm, Kazatomprom (10 percent). In 
2015, Toshiba was hit with a scandal where it was revealed profits had been overstated, particularly with its holdings in Westinghouse. Toshiba had been hoping that the link with Kazatomprom would strengthen its opportunity to supply nuclear technology and infrastructure into Kazakhstan (WNA 2018). With this link, Toshiba set up a R\&D facility in the northeastern town of Kurchatov together with the assistance of Toyota and Marubeni (WNA 2018). After the accounting scandal hit Toshiba, in March 2017 Westinghouse filed for bankruptcy, and in 2017 Kazatomprom required Toshiba to buy out its share of Westinghouse for $\$ 522$ million (WNA 2018). In January 2018 Westinghouse was sold to Canadian firm, Brookfield, for $\$ 4.6$ billion (Mattioli, et al. 2018, B1).

Japanese companies remain active in the nuclear industry in Kazakhstan through uranium mining, processing, and $\mathrm{R} \& \mathrm{D}$, but these activities are more for building access to energy, and not for access to markets. Moreover, if the nuclear-energy age is over for Japan, what is the use in securing access to uranium? As for access to markets, the prospects as supplying nuclear energy technology and infrastructure are deeply diminished by Westingthouse's bankruptcy and sale, and Toshiba's accounting scandal and subsequent stripping of assets including Westinghouse. Kazakhstan is a long-shot market for Japanese companies. Toshiba and Westinghouse have tainted their images, and competition is fierce among Russian and Chinese firms for the market. In Central Asia, "Japan is ill-equipped to compete with Russia and China when in direct competition for reasons both cultural and regional” (Barber 2018, 30).

India and Japan signed a full nuclear cooperation agreement in November 2016, which allows India to import Japanese nuclear technology, despite being a non-signatory 
to the Nuclear Non-Proliferation Treaty, and grants India Japan's support for it to join the Nuclear Suppliers Group (NSG). To date, India has not committed to receiving technology and infrastructure from any Japanese supplier. This agreement is discussed further in Chapter 7, but for the purposes of this chapter, there is potential for nuclear technology exports by Japan. India is showing potential to import. Saudi Arabia is showing potential to import, as are UAE, Jordan, Indonesia, Bangladesh, and even Kazakhstan. Assuming Japan does not restart is nuclear reactors, and proceeds as a postnuclear energy society, the technology will move along and its firms will gradually disappear from the global market, which is growing in spite of Fukushima, the "nuclear allergy' that has emerged in Japan, and plans from other developed countries, like Germany, to forgo nuclear energy in the future. The Abe administration may have known this, and thus the plan to make nuclear power technology a key export was a short-term solution for economic growth.

\section{Services Sector}

Japan is often referred to as a 'manufacturing state,' but the services sector occupies an increasing portion of Japan's GDP (Morikawa 2016, 33). It is also the fastest growing type of exports globally, so it is natural that Tokyo pursues this, as its cornerstone manufacturing industry is slipping among competition. Unemployment figures are very low in Japan; in fact, there are more jobs available than there are job seekers (Sternberg 2018, A15). Businesses suffer from labor shortages, yet economic growth remains mostly stagnant. These long-term conditions indicate that "the Japanese economy is near the ceiling of its supply capacity; the economy is not bad but the economic growth rate is weak" (Morikawa 2016, 32). 
With this in mind, the services sector must increase exports in order to increase economic growth. Services make up three-quarters of Japan's total GDP, yet even after a decade of increases, just over one-quarter of Japan's exports (Nakata 2015, 1). That pales in comparison to other developed economies like the U.S., the largest service exporter, where 52 percent of its total exports are from the services sector, and the UK, where a substantial 82 percent of its exports are from the services sector (CIA World Factbook 2018). In 2014, Japan's services sector exports total 17.3 trillion yen, with 4.2 trillion yen, or nearly a quarter of all services sector exports, in the form of transport services (Nakata 2015, 1). Intellectual property rights and license fees made up 3.9 trillion yen, or 22.5 percent, although this is mostly exported to North America (Nakata 2015, 1). Travel made up 2 trillion yen (11.6 percent), and construction, 1.2 trillion yen (6.9 percent) (Nakata 2015, 1). Within the services sector, the financial services and tourism industries are noteworthy in how they relate to Muslim Asia.

The thriving financial services wings of the old zaibatsu, Mitsubishi UFJ, Sumitomo Mitsui, and Mizuho, are some of the largest financial service providers in the world. As lenders, these firms are allowed to provide Islamic financial products via overseas subsidiaries, yet they have a tendency to avoid investing in certain Muslim countries due to Islamic banking practices. This avoidance is mostly due to the lack of understanding and risk associated with venturing into an environment with unfamiliar laws and practices. Japanese financial services firms are, however, attempting to revise banking laws and regulations in Japan to encourage Islamic financing (Tsukioka 2017: Tahara 2009, 189). Moreover, the Japan Bank of International Cooperation (JBIC) has been allowed to offer shari'a-compliant financial products (Tsukioka 2017). 
Islamic banking institutions appeared in the mid-twentieth century amid concern over the morality of the capitalist system developing in the Muslim world (Tripp 2006, 51-56). Contrary to conventional expectations, Islamic banking got its earliest start not in the Middle East, but in Southeast Asia - especially, Malaysia, Brunei, and Singapore. Japan indirectly interacted with this early Islamic banking, when in 1980 Malaysians used Islamic financial tools to promote domestic ownership of the automobile manufacturing industry that was dominated by Japanese at the time (JBIC 2007, 3). As petrodollars accumulated in the oil-rich Gulf region during the 1970s and 1980s, more Middle Eastern markets also opened to Islamic banking. Malaysia and Brunei are two of the largest centers for the Islamic financial market (JBIC 2007, 3). Islamic banking is rapidly growing globally, and provides an opportunity to engage with a broad network of clients, including many ethnic Chinese in Southeast Asia who are not necessarily Muslim, but prefer the approach to conventional finance (Al-Maraj 2009, 1-2: Tahara $2009,192) .{ }^{5}$ There is a push among many in the Islamic financial services industry to promote 'interfaith banks' which target segments of societies which desire moral-based banking based on their respective religious traditions (Simpfendorfer 2014, 68). These efforts are mostly found in Southeast Asia and Western Europe, but there is also tremendous potential in Japan as well.

It is likely the Japanese government will allow the necessary revisions to the banking laws and regulations, as it is imperative to boost infrastructure investment and general exports from the financial services industry (Tsukioka 2017: JBIC 2007, 3).

\footnotetext{
${ }^{5}$ It is estimated Chinese-Malays make up 40 percent of the sales at Islamic financial institutions in Malaysia (Simpfendorfer 2014, 69).
} 
Meanwhile, it would encourage more Muslim engagement in Japan's bond market - the largest bond market in Asia (Wada and Vizcaino 2015). Bonds in Islamic banking are different than in conventional banking, in that bonds, or sukuk, are tradable, and "the coupon payments on them represent profits on real economic activities rather than the payment of interest" (Al-Maraj 2009, 1). Overseas, however, the engagement with Islamic banking has been timid. Mitsubishi UFJ was the first Japanese firm to issue sukuk, or Islamic bonds, through a subsidiary in Malaysia (Wada and Vizcaino 2015). Sumitomo Mitsui is also offering Islamic banking in Malaysia, with an in-house shari'a advisory board (Wada and Vizcaino 2015).

The second services-sector industry to note is the tourism industry, which is categorized as services export. Much attention is given to annual increase in the number of foreign visitors to Japan, and even though it makes a minor contribution to total services sector exports, it greatly raises consciousness of Muslim peoples and Islamic practices among Japanese because it increases human-to-human contact, exchange, and transactions. The number of Muslim tourists from Asia has increased dramatically in the last decade, particularly from East and Southeast Asia (see Table 5.4). Tourists from Indonesia are among the fastest growing nationality of tourists, increasing as much as 30 percent annually over the last five years. Indonesians also make up the largest nationality of Muslim tourists in Japan, with about 239,000 Indonesian Muslims visiting Japan in 2016. As a food culture, with deep interests in health and diets, there is a curiosity regarding the halal diet in Japan. Moreover, there is an eagerness among many restaurateurs and food-way suppliers to accommodate Muslims in Japan who follow a halal diet (Miyata 2017, 240). Several hotels and restaurants are applying to be halal 
certified, and list with Japan Muslim Guide, an online travel website that lists hotels, restaurants, and mosques for Muslims visiting, or living in Japan. As of the last decade, major airports and train stations have also added prayer rooms to accommodate Muslim visitors (Miyata 2017, 241).

While relatively small, the tourism industry does have room to expand for Muslim Asians. Along with the accommodations made by restaurants, hotels, airports, and train stations, Miyata promotes expanding the market for Muslim visitors to Japan to include medical tourism: "since we have halal restaurants and halal hotels, we should also have halal hospitals" (2016: 54). For example, Miyata suggests "female patients can seek arrangements such as being seen by a female physician. Muslim people have historically trusted Japanese technological skill, so in healthcare, too, trust could be cultivated" (2016: 54). Elsewhere, he argues "as a country renowned for the longevity of its people, Japan could be an attractive destination for medical tourism and Muslims in general who are health-minded" (2017: 245).

Japan is the fourth largest exporter in the world, but ranks seventh in services sector exports (Morikawa 2016, 33). Japan's services sector exports only make up 3.2 percent of global services sector exports in 2014, while its services sector makes up just over 7 percent of the world's services product (Nakata 2015, 10: CIA World Factbook 2018). Japan's services industries are undoubtedly geared to the domestic market that is high-consuming and aging. Yet, there is tremendous potential to export industries in the services sector. Japan has some of the largest services sector corporations in the world, such as telecommunications giant SoftBank, Rakuten in ecommerce, and Dentsu in advertising. Services sector exports tend to face different challenges than product-based 
exports. Language barriers can be significant, as can knowledge of legalities, regulations, and customs. Distance barriers are a more significant variable than with product-based exports. These constrain services sector exports to only the largest corporations which are better-equipped for such challenges.

\section{Constructing Post-Oil Relations}

This chapter shows that Japan was once a net importer from Muslim Asian countries. In the age of petroleum, Japan's dependency on fossil fuel resources from certain Muslim Asian countries has acutely tilted the trade balance whereby a tremendous outflow of capital from Japan to the petrostates is not being matched by Japanese exports. Yet, nascent indicators of an, at most, post-oil relationship, and, at least, economically multifaceted relationship between Japan and Muslim Asia is taking form. Yamauchi argues that the Middle East "has multifaceted plans to develop eco-friendly industrial infrastructure using low-cost fuels, function as an international logistics hub by taking advantage of its geographical location and expand international financial services centers managing oil revenues" (2010). With this in mind, there is ample room for a state like Japan to engage with the region in a new way. This section looks at two possibilities of budding post-oil relations between Muslim Asia and Japan into the twenty-first century: the Saudi-Japan Vision 2030, and the Trans-Pacific Partnership (TPP) sans the U.S. Both, however, have geopolitical problems with which Tokyo will have to contend.

Saudi-Japan Vision 2030

In April 2016, Crown Prince Mohammad bin Salman of Saudi Arabia announced a government plan he called 'Saudi Vision 2030.' In this, he outlined a plan, albeit vaguely, for Saudi Arabia to shift from dependency on the petroleum export industry to a 
comprehensively developed economy. Nearly a year later, in March 2017 King Salman bin Abdulaziz of Saudi Arabia visited Japan, the first time the Saudi King had visited Japan in nearly half a century. He and Abe announced the Saudi-Japan Vision 2030,' which was to accompany the 'Saudi Vision 2030' announced the previous year. Both sides noted a "synergy" between their societies and their economies that, if strengthened, would benefit both sides. Within this synergy, Riyadh hoped to gain from Japan strategies to diversify its economy, reform its economy, and apply "soft value" "strengthening the social and cultural foundations to stimulate the economy" (MOFA 2017a). To incentivize business development, the plan called for special economic zones in Saudi Arabia, and in the meeting Abe pressed for negotiating a free-trade arrangement with the GCC. The plan detailed 31 potential projects to strengthen Saudi-Japanese relations, and build on this synergy identified. The CEO of SoftBank, Son Masayoshi, also met with the Saudi King, where they drafted plans for the 'Softbank Vision Fund,' which would combine 2.5 trillion yen from Softbank and 4.7 trillion yen from the Saudi sovereign wealth fund, the Public Investment Fund, for technology investments (Takeyama, et al. 2017).

The projects include among them, Tokyo's suggestion for Riyadh to list Aramco on the Tokyo Stock Exchange. As part of Saudi Arabia's reforms, Riyadh announced in early 2016 the NOC Aramco would list five percent of its value publicly. In 2018, the initial public offering was postponed to no earlier than 2021, adding more time for markets to compete. Aramco has been solely owned by the King of Saudi Arabia since 1980. It is expected to be the biggest IPO in history, possibly up to $\$ 100$ billion (Lee, et al. 2017: Asahi Shimbun 2017). New York, London, and Hong Kong are also vying to 
have Aramco list with their markets. Meanwhile, Chinese oil companies PetroChina and Sinopec offered to directly purchase the five percent of Aramco, which would prevent it from appearing on any market (Asahi Shimbun 2017). If it does appear on the market, Japan has, among others, a sovereign wealth fund ready to acquire stakes in the company (Asahi Shimbun 2017).

Geopolitical considerations abounded with the Saudi-Japan Vision 2030. Many overlooked it, since the King's visit to Japan was subsequent to visits to Indonesia, Malaysia, and China, where he signed deals worth $\$ 65$ billion. The synergy between Saudi Arabia and Japan may be palpable, but Tokyo will be challenged and undercut by Chinese competition in many faucets of cooperation with Riyadh. China is closer, larger, less expensive, and much more flexible and daring regarding FDI projects. For Saudi Arabia, this was a shift in preparing to become a post-petro state, but Riyadh also had Iran in mind, which is something Tokyo must cautiously take into consideration. Corben argues the initiative "could be interpreted as a double standard given the international community's efforts to constrain Iran's own nuclear aspirations, and could complicate Tokyo's attempts to rejuvenate its economic relationship with Tehran and diversify its own energy portfolio" (2017). Japan, or China for that matter, cannot avoid entanglement in geopolitical confrontations in the Persian Gulf region if they choose to strengthen relations with Saudi Arabia or Iran.

\section{CPTPP}

After the U.S. formally withdrew from TPP in January 2017, there was initial skepticism in Tokyo regarding the future of the pact. It was a daunting political challenge for Abe to get the original TPP agreement ratified in the Diet, and he faced immense 
opposition even from within his own party and among key constituents. So, when U.S. President Trump took office and, as promised during his campaign, withdrew the U.S. from TPP within his first week in office, it was a tremendous blow to Abe who had invested so much to have the agreement ratified in his own country, and even jeopardized his political capital in order to get the bill passed. Abe initially declared TPP as "meaningless" without U.S. participation, yet perhaps because of the time and effort invested in ratifying TPP, weeks later Deputy Prime Minister and Finance Minister Asō Tarō announced Japan would proceed with TPP together with the remaining ten memberstates, insisting "there will be no renegotiation on the TPP's current framework" (Miller 2017). By 2018, all remaining member states indicated enthusiasm to proceed with the bloc, and it was rebranded into a more cumbersome, Comprehensive and Progressive Agreement for Trans-Pacific Partnership (CPTPP).

If CPTPP can withstand the American departure, Japan is poised to assume a leadership role in the bloc. Without the U.S. or China in the regional economic bloc, Japan is poised to assume a role similar to Germany's central role in the European Union - except Japan's economy is substantially larger than Germany's in relation to the other states in their respective economic blocs, and the 11-member states of CPTPP make up a market of half a billion people - larger than the EU market. Japan's nominal GDP is nearly as large as the other ten CPTPP member-states combined, and it provides a significant platform to access Muslim consumers in Southeast Asia. Some of Japan's biggest Muslim markets already are in Malaysia and Singapore, which are both party to CPTPP, as is the wealthy Islamic sultanate, Brunei. Moreover, Japan's biggest Muslim trading partner, Indonesia, has indicated its intention to join CPTPP as well. 
There are geopolitics at play here too; China is notably not party to CPTPP, and is instead promoting the Regional Comprehensive Economic Partnership (RCEP), along with the Asian Infrastructure Investment Bank (AIIB) and One-Belt, One-Road Initiative. As CPTPP rules are currently constructed, China would have to make substantial reforms in order to be considered for membership, such as de-subsidizing its multitude of stateowned enterprises, strengthening transparency on bribery, and increasing enforcement of intellectual property rights. Also, the U.S. may reenter the agreement later, albeit not easily. If the U.S. successfully reenters CPTPP, or if China can either squelch CPTPP with its own trade initiatives, or join, it affects Japan's current leadership role in salvaging the trade bloc. Regardless if CPTPP proceeds, or RCEP, or both, it opens up the opportunity to strengthen "the efficient operation of a regional production network" that further links Muslims in Asia to Japanese exports (Shiroishi 2017, 30).

\section{Conclusion: Where is Islam?}

This chapter examines several facets of contact between Japan and Muslim Asia to consider Japan's strategy to access markets in Muslim Asia for exports and FDI. Table 5.5 shows a typology of states in Muslim Asia significant as either current essential markets, or potential essential markets for future planning in the auto industry, HSR industry, and services sector. Moving forward, this typology is taken into consideration together with energy suppliers in the last chapter, and further facets of contact in the next three chapters.

Considering this typology and other findings, five conclusions come from this review. First, there are sorts of markets within Muslim Asia. Notable NIEs in Muslim Asia are namely Malaysia and Indonesia, but also Turkey and Kazakhstan. These four are 
turning into key consumer market destinations for exporters. Beyond these, there are two other types of consumer markets in Muslim Asia. First are the oil-rich states, flush with petrodollars and targets for luxury item exports. These include Qatar - the most affluent population in Muslim Asia, UAE - with its largest city, Dubai, as the business and tourism hub of the Middle East, Saudi Arabia - with the most millionaires in Muslim Asia, Kuwait, Bahrain, and Oman. Yamauchi argues "[i]t certainly makes perfect sense for people - regardless of whether or not they are Muslim - to seek making themselves rich by dealing with the six wealthy Gulf Cooperation Council states" (2010). The most influential thinktank in Japan, the Japan Institute of International Affairs (JIIA), argues:

In the Gulf States, infrastructure maintained since modernization in the 1970s and 1980s is now dilapidated, and coupled with rapid population growth infrastructure improvements are imperative. Also, from water desalination for home use, to electrification (especially renewable energy), to rising living standards and aging societies with high expectations in the medical field, investment demands are expanding. Gulf States have great expectations from Japan for high-technology, but on the other hand, it is necessary Japan works hard to avoid failing in business project bids when there is competition (JIIA 2017: 6).

The list should also include Brunei - with the Sultan often considered the wealthiest individual in the world. While some of these petro-states illustrate tremendous economic inequalities, there is also mass consumerism, and they serve as magnets for trade wealth opportunities. The rich in these states spend enormous amounts, and are key markets for an exporting state like Japan, with its emphasis on the distinctive quality of its products.

The final group are populations in Muslim Asia that not necessarily from the NIEs, yet rapid population growth, urbanization, and rapidly improved literacy rates and internet connectivity indicate these locations will be significant markets in the near future (Roser and Ortiz-Ospina 2017). This is the case for a band of states from the Levant 
(Lebanon, Jordan, and Palestine), to Iraq, Iran, and across South Asia (Pakistan, Muslim populations in India, and Bangladesh). Globally, Muslim Asia's youthful population is second only to that of Sub-Saharan Africa as a percentage of its society. Demographics dictate that the center of Islam will shift to South Asia over the course of the twenty-first century. Meanwhile, the core of global commerce has also shifted east, and South Asia is a key part of this as well.

Second, of all facets of contact between Japan and Muslim Asia examined in this project, access to markets is seemingly the most remote from threats, security, and strategy. Many of the actors strategizing export markets and FDI are corporations, but as noted in this chapter, Tokyo, does so as well on these corporations' behalf. Geoeconomics is seemingly at the heart of accessing markets, and geopolitics and geoculture are seemingly insignificant. This view, however, is lacking a clear understanding of how these variables interplay. Hayes points out "[m]any Japanese companies are opening overseas factories in order to gain a better political relationship with the host country, in addition to economic advantages such as cheap labor" (2018: 213). The body of this chapter (as well as chapters 4 and 5) illustrates the tight relationship between big business and political elites in Tokyo. Abe has promoted his country's business on trips across Muslim Asia, and as seen in Chapter 3, these businesses have a strong influence on policy in Tokyo. The partitioning of state and non-state actors, seen in much of international relations literature, is misleading as the dynamics between these two take on unique characteristics and can proxy for each other's interest as composite parts of each state-system, including Japan's. 
Moreover, geo-culture is evident in these decisions. Values-based diplomacy is at hand in export markets and FDI decisions. Miyata (2014b) makes this case by citing Uni Charm, a Japanese hygienic products company that has FDI factories employing thousands of women in Indonesia, India, and Saudi Arabia. Miyata argues that Japanese corporate investment, like that of Uni Charm, has the potential to "reduce poverty in the Muslim Middle East, and elevate the social status of women, thereby having the effects of bringing down the birth rates and controlling population growth" (2014b: 229-30). He further adds " $[t]$ he result of this could be useful in decreasing the violence and conflict in the Muslim Middle East" (2014b: 230). Miyata identifies this business model as an "asset" that is available for Japan, which can cultivate a more positive relation with Muslim societies in Asia (2014b: 230).

Third, much as securing access to energy is deeply rooted in Japan's fundamental security, as established in the last chapter, securing access to export markets is also deeply rooted in Japan's security. Political economy observers as well as trade competitors have derided this as neo-mercantilism, and protectionism. Since the opening of Japan in the mid-nineteenth century, overcoming innate inferiorities in order to survive has been deeply imbedded in the national identity. The root of this inferiority complex is partially because the Japanese have tended to compare themselves with resourceabundant U.S., China, and Russia, and with European powers with a robust horizontal trade network among them. This partially explains the attempts to mimic, and seek peerage with the West during the Meiji Restoration, to expand and colonize territories in Asia, and to secure the supply of oil in the postwar era. 
Securing consumer markets overseas is essential for bringing in capital. As certain industries surveyed above indicate, Japan is being undercut by China and South Korea for cheaper products, but they could be an indicator of the aforementioned FGT. Thus, Japan must move on to the next stage of development - whatever that is. FGT is undoubtedly present in Japan's thinking of itself and Asia. So much so, it is a source of pride, since Japan views itself as the goose at the tip of the formation. Yet, there is a looming problem with FGT, in that Akamatsu did not indicate, or prescribe where to go next. In fact, when the last manufacturing industry declines, as Akamatsu predicted, where does the economy go? There is no mention of a services sector in the 1930s model, although we presume that is the next phase to emerge.

Fourth, as a grey market, the used auto market is a side effect of Japan's stringent road safety standards and the centrality of domestic sales to maintain a robust automobile industry. It is an 'ethnic business,' and operated largely by Pakistani and Bangladeshi residents in Japan and UAE. This hand-me-down model is neither condoned nor discouraged by the Japanese government, but it plays a very important role in spreading a positive reputation for the quality of made-in-Japan products across the Indian Ocean, elevating the status of these products, making them more accessible to wide swaths of Muslims in Asia who otherwise would not have access to these vehicles. As discussed, a young consumer class is burgeoning in Muslim Asia, and many are purchasing branded products for the first time. Serendipitously, the used auto market is an excellent means "to build brand loyalty, rather than having to convince consumers to switch later in life, unlike in older and more mature markets such as America and Europe and even increasingly in China" (Simpfendorfer 2014, 71-72). 
Lastly, Japanese overseas investment and exports have an additional challenge to the previously mentioned, known in Japan as the 'Galapagos syndrome.' In many regards, Japan leads the world in several heavy machinery and high-technology fields, but products are usually designed to cater to a high-consuming domestic market accustomed to a distinguishable quality (Yamauchi 2010). Thus, the technology evolves to meet specific domestic demands, and thereby overlooks emerging demands overseas. Countries with similar economic structures, like Germany and South Korea, are better catered to a more global market, and thus, better equipped to operate in foreign markets. The Japanese automobile industry obviously has averted the Galapagos syndrome, and has considerable overseas autonomy and $R \& D$ that has allowed it to remain competitive and even dominate certain markets, but other industries - notably consumer electronics have suffered by not adequately preparing for the global demands for digital technology like the smartphones. The services sector may face similar challenges as it turns outward in the following years.

Where is Islam? Where are the Muslims? In trade economics, it may be easy to overlook this. The research shows Indonesia is of paramount importance for Japan's access to markets, and more than half of Indonesia's population is located on Java. On Java, alone, can you find over 130 million Muslims residing in a 50,000-square mile area (although Bangladesh would be a close second). Jakarta, a city of over 27 million Muslims, has more Muslims than any other urban area in the world. The significance of Indonesia's Muslims is often overlooked - even by Muslims elsewhere in the world. These people are essential consumers of Japan's exports, and Japan's economic outlook for the twenty-first century must facilitate increasing access to the Muslim Asia markets, 
which are expanding in both wealth and population. Therefore, securitization relates insofar as Japanese choose to enthusiastically engage with these markets, or avoid them despite the economic opportunities they provide. This chapter reveals that both are happening simultaneously. Indonesia, for example, is a key export market; there is clear tepidness, however, observed with Iran. 
Table 5.1: Japan Export Markets, 2015 (in millions of USD)

\begin{tabular}{lll}
\hline 1 & U.S. & $\$ 126,387(20.2 \%)$ \\
2 & China & $\$ 109,278(17.5 \%)$ \\
3 & South Korea & $\$ 44,019(7.0 \%)$ \\
4 & Hong Kong & $\$ 35,006(5.6 \%)$ \\
5 & Thailand & $\$ 27,984(4.5 \%)$ \\
6 & Singapore & $\$ 19,855(3.2 \%)$ \\
7 & Germany & $\$ 16,237(2.6 \%)$ \\
8 & Australia & $\$ 12,850(2.1 \%)$ \\
9 & Vietnam & $\$ 12,531(2.0 \%)$ \\
10 & Malaysia & $\$ 12,004(1.9 \%)$ \\
11 & Netherlands & $\$ 11,598(1.9 \%)$ \\
12 & Indonesia & $\$ 11,539(1.8 \%)$ \\
13 & UK & $\$ 10,740(1.7 \%)$ \\
14 & Mexico & $\$ 10,475(1.7 \%)$ \\
15 & Philippines & $\$ 9,488(1.5 \%)$ \\
16 & UAE & $\$ 8,695(1.4 \%)$ \\
17 & India & $\$ 8,110(1.3 \%)$ \\
18 & Canada & $\$ 7,736(1.2 \%)$ \\
19 & Saudi Arabia & $\$ 6,826(1.1 \%)$ \\
20 & France & $\$ 5,261(0.8 \%)$ \\
& TOTAL & $624,874(100 \%)$ \\
\hline Source:WITS(2017)
\end{tabular}

Source: WITS (2017). 
Table 5.2: Largest Trade Partners in Muslim Asia, 2016 (in millions of USD)

\begin{tabular}{|c|c|c|c|c|c|}
\hline & & Total & Japanese Exports & Japanese Imports & $\begin{array}{c}\text { Trade } \\
\text { Balance }\end{array}$ \\
\hline 1 & Indonesia & $\$ 29,542$ & $\begin{array}{c}\$ 11,328 \\
\text { Capital goods, machinery } \\
\& \text { electronics, } \\
\text { intermediate goods }\end{array}$ & $\begin{array}{c}\$ 18,215 \\
\text { Fuels, raw materials, } \\
\text { consumer goods }\end{array}$ & $(\$ 6,887)$ \\
\hline 2 & Malaysia & $\$ 29,474$ & $\begin{array}{c}\$ 12,139 \\
\text { Capital goods, machinery } \\
\& \text { electronics, } \\
\text { intermediate goods }\end{array}$ & $\begin{array}{c}\$ 17,334 \\
\text { Consumer goods, } \\
\text { fuels, machinery \& } \\
\text { electronics }\end{array}$ & $(\$ 5,195)$ \\
\hline 3 & UAE & $\$ 25,295$ & $\begin{array}{c}\$ 7,997 \\
\text { Transportation, consumer } \\
\text { goods, capital goods }\end{array}$ & $\begin{array}{c}\$ 17,299 \\
\text { Fuels, raw materials, } \\
\text { consumer goods }\end{array}$ & $(\$ 9,302)$ \\
\hline 4 & Saudi Arabia & $\$ 24,600$ & $\begin{array}{c}\$ 5,030 \\
\text { Transportation, consumer } \\
\text { goods, capital goods }\end{array}$ & $\begin{array}{c}\$ 19,570 \\
\text { Fuels, raw materials }\end{array}$ & $(\$ 14,540)$ \\
\hline 5 & Qatar & $\$ 12,420$ & $\begin{array}{c}\$ 1,539 \\
\text { Transportation, consumer } \\
\text { goods, capital goods }\end{array}$ & $\begin{array}{c}\$ 10,880 \\
\text { Fuels, consumer } \\
\text { goods, raw materials }\end{array}$ & $(\$ 9,341)$ \\
\hline 6 & Kuwait & $\$ 5,938$ & $\begin{array}{c}\$ 1,697 \\
\text { Transportation, consumer } \\
\text { goods }\end{array}$ & $\begin{array}{c}\$ 4,241 \\
\text { Fuels, raw materials }\end{array}$ & $(\$ 2,545)$ \\
\hline 7 & Oman & $\$ 4,311$ & $\begin{array}{c}\$ 2,552 \\
\text { Transportation, consumer } \\
\text { goods, capital goods }\end{array}$ & $\begin{array}{c}\$ 1,759 \\
\text { Fuels, raw materials, } \\
\text { consumer goods }\end{array}$ & $\$ 793$ \\
\hline 8 & Iran & $\$ 3,912$ & $\begin{array}{c}\$ 582 \\
\text { Capital goods, } \\
\text { transportation, machinery } \\
\& \text { electronics }\end{array}$ & $\begin{array}{c}\$ 1,759 \\
\text { Fuels, raw materials }\end{array}$ & $(\$ 2,749)$ \\
\hline 9 & Turkey & $\$ 3,424$ & $\begin{array}{c}\$ 2,861 \\
\text { Capital goods, machinery } \\
\& \text { electronics, } \\
\text { intermediate goods }\end{array}$ & $\begin{array}{c}\$ 563 \\
\text { Consumer goods, } \\
\text { textiles \& clothing, } \\
\text { raw materials }\end{array}$ & $\$ 2,298$ \\
\hline 10 & Bangladesh & $\$ 2,799$ & $\begin{array}{c}\$ 1,583 \\
\text { Intermediate goods, } \\
\text { metals, capital goods }\end{array}$ & $\begin{array}{c}\$ 1,216 \\
\text { Consumer goods, } \\
\text { textiles \& clothing, } \\
\text { footwear }\end{array}$ & $\$ 367$ \\
\hline
\end{tabular}

*Excludes trade with Muslim-minority states in Asia Source: WITS (2017). 
Table 5.3: Largest New Auto Sales in Muslim Asia Markets

\begin{tabular}{llccc}
\hline & & $\begin{array}{c}2006 \\
\text { total units }\end{array}$ & $\begin{array}{c}2016 \\
\text { total units }\end{array}$ & $\begin{array}{c}\text { ten-year } \\
\text { growth }\end{array}$ \\
\hline 1 & Iran & 971,000 & $1,448,500$ & $49 \%$ \\
2 & Indonesia & 318,904 & $1,048,134$ & $229 \%$ \\
3 & Turkey & 617,838 & $1,007,857$ & $63 \%$ \\
4 & Saudi Arabia & 556,100 & 655,500 & $18 \%$ \\
5 & Malaysia & 490,748 & 580,124 & $18 \%$ \\
& Global TOTAL & $68,353,376$ & $93,856,388$ & $37 \%$ \\
\hline
\end{tabular}

Source: Adapted from OICA (2018).

Table 5.4: Muslim Tourists to Japan by Nationality, 2016

\begin{tabular}{lc}
\hline 1. Indonesia & 239,000 (up $32.1 \%$ from 2015) \\
2. Malaysia & $238,100(29.1 \%)$ \\
3. China & $114,000(27.6 \%)$ \\
4. Hong Kong & $75,400(20.7 \%)$ \\
5. Singapore & $51,700(17.2 \%)$ \\
6. Thailand & $49,600(13.2 \%)$ \\
7. France & $22,200(18.3 \%)$ \\
8. Philippines & $19,000(29.6 \%)$ \\
9. Turkey & $17,800(5.1 \%)$ \\
10. UK & $17,500(13.1 \%)$ \\
\hline
\end{tabular}

Source: Adapted using data from JNTO (2017). 
Table 5.5: Market Significance for Japan

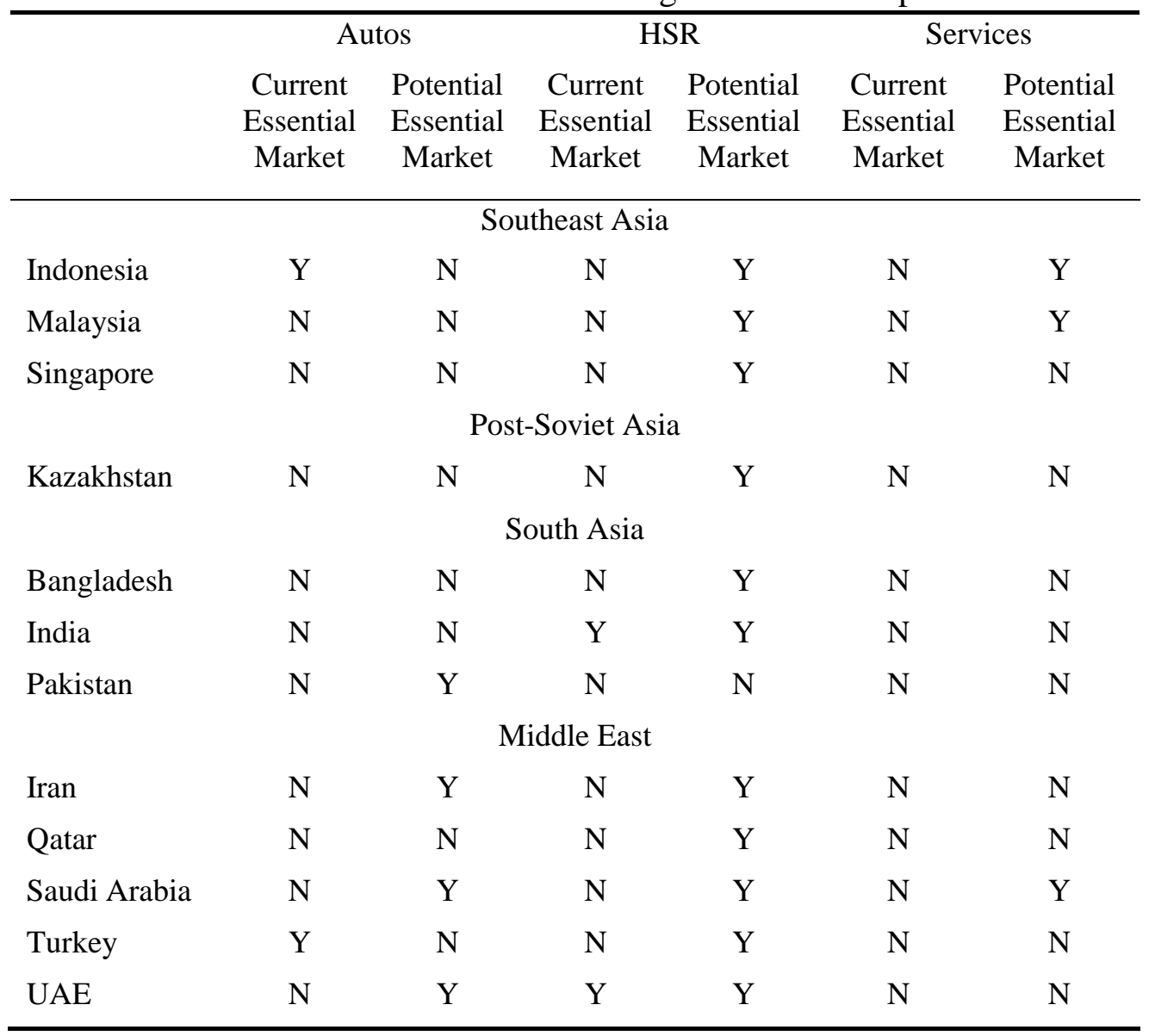


Figure 5.1: Flying Geese Theory Model: Transition of Dominant Economy Sector

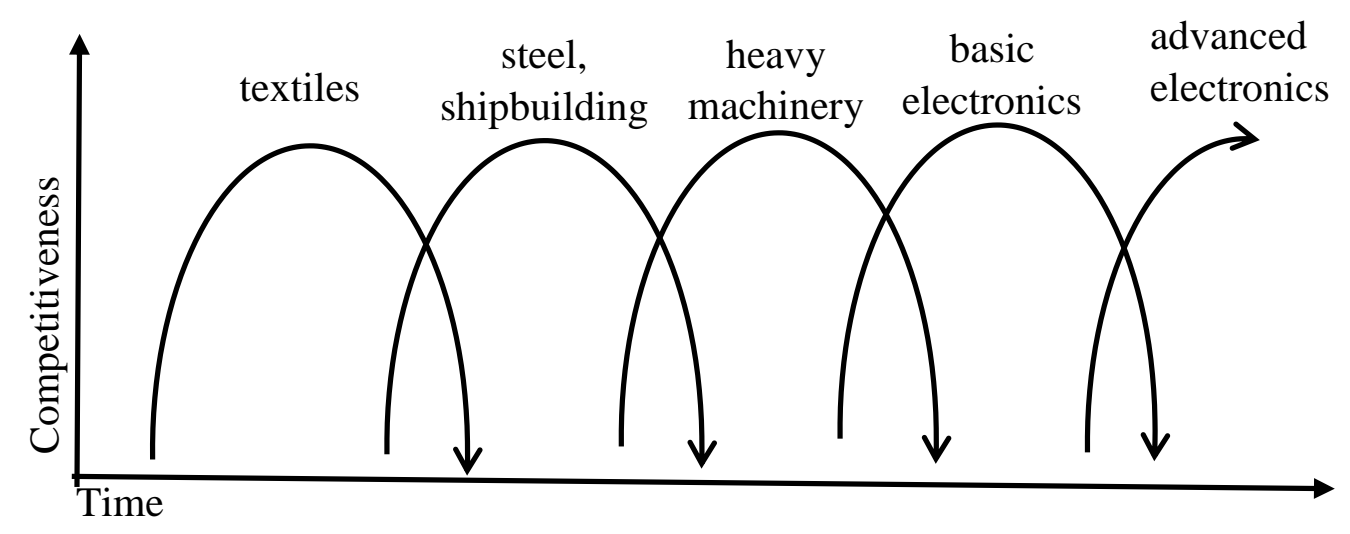

Source: Adapted from Sun $(2017,27)$. 
Figure 5.2: Flying Geese Theory Model: Transition of State Competitiveness in Individual Sector

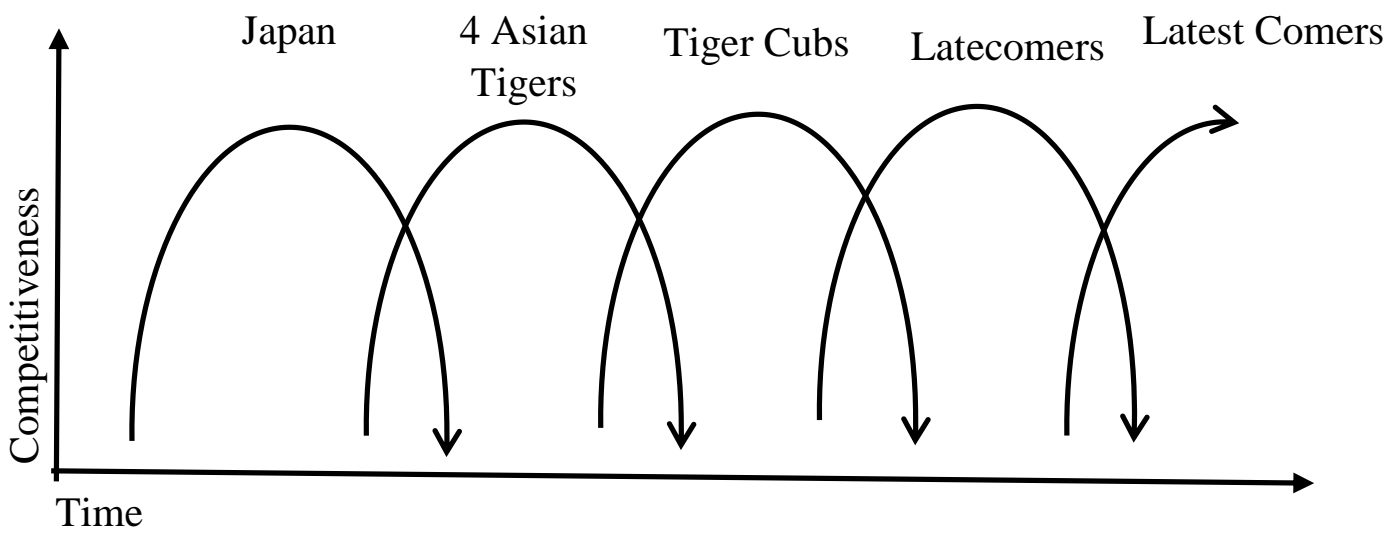

4 Asian Tigers: Hong Kong, Singapore, South Korea, Taiwan

Tiger Cubs*: Indonesia, Malaysia, the Philippines, Thailand

Latecomers: India, Vietnam, others

Latest Comers: Bangladesh, Pakistan, others

* Could include Turkey, as an NIE, but would probably fall beyond geographic scope.

Note: China defies the model, but would suitably fit somewhere between 4 Asian Tigers and Tiger Cubs.

Note: Petrostates do not fit the model, and thus are left out.

Source: Adapted from Sun $(2017,27)$. 


\section{CHAPTER VI}

\section{DEVELOPMENT AND AID}

Japan has played a pivotal role in development assistance programs for many states in the last half-century, and remains one of the primary sources of official development assistance (ODA) for many countries. Yet, the underlying rationale behind Japan's development assistance policy over the decades is a rich source to illuminate norms, strategy, and its own perceived role in the world, but specifically, in Asia. As discussed in Chapter 3, when Japanese Foreign Minister Asō Tarō announced the 'Arc of Freedom and Prosperity,' it made Japan's values in foreign policy more overt, and the speech contained unambiguous language of "economic prosperity," and references to Japan's role "[i]n assisting countries as they take...steps forward," and serving "as an "escort runner' to support these countries" (2006b). These, however, were not new, just explicit values.

Development assistance is a tool of Japan's foreign policy which has been a primary conduit in the postwar era for efforts to strengthen relations with other states, and their societies around the world. The significance of development assistance as a tool for foreign policy is partially due to Japan's constrained military spending, which has resulted in more emphasis on the carrot than on the stick in terms of strategy. This carrotbased strategy has ramifications, some intended and some not. What are the intended objectives to this strategy? What are the unintended outcomes? Asō clearly indicated this linkage, but how does it interact with a simultaneous securitization of Islam? While many developing states around the world receive development assistance from Japan, Asian states receive overwhelmingly the most, which should come as no surprise. Moreover, 
Muslim Asian states are also large recipients of Japan's development assistance. How does this interact with the grand strategy, foreign policy, and security?

To parse the norms, strategy, role, objectives, and of course, formulate how securitization is operating in Tokyo's foreign policy with Muslim Asia, the triangular symbiotic framework is a suitable analytical framework. All three facets of foreign policy, geoculture, geo-economics, and geopolitics, are evident in Tokyo's development assistance policy vis-à-vis Muslim Asia states. This chapter examines Japan's development assistance programs in Muslim Asia, as it relates to the Arc, and to securitization of Islam. In securitization theory, the urgency of a perceived threat has a saliency sufficient to deem it necessary to circumvent ordinarily prescribed rules, and, thus, can have substantial political outcomes. The chapter proceeds by first providing a brief background of Japan's postwar development assistance policy, then analyzes the three development assistance charters which provide a nuanced understanding of Tokyo's norms, strategy, role, and objectives with the foreign policy tool, which also evolves through each version. The following section considers the morality of loan assistance, and how this is conceptualized in Japanese and Islamic thought. Lastly, the chapter proceeds by examining contemporary cases and challenges which allow for comparisons of securitization.

\section{Background}

Before becoming an aid-donor nation, postwar Japan was first an aid-recipient nation. Much of the urban infrastructure, capital stock, and assets that built a modern empire during the late-nineteenth and early-twentieth century were destroyed during the war, banks were drained of capital, and businesses were bankrupt. Yet, during the postwar 
occupation, serendipitously, U.S. forces found it strategically necessary to 'prop up' Japan and make it "a model of economic success that displayed the vitality and possibilities of embracing the democratic capitalistic system" (Feasel 2015, 11). U.S. President Eisenhower told congressional leaders in 1954, "If we don't assist Japan, gentlemen, Japan is going Communist" (LaFeber 1997, 306). A strong, democratic Japan was essential for the U.S. strategy to contain the Soviet Union during the Cold War, so Washington offered substantial development assistance to Japan in order to revitalize its destroyed manufacturing industry, and also opened up a massive and affluent market of American consumers where Japan could export these products. From 1946 until 1951, Japan was the recipient of nearly $\$ 2$ billion in aid from the U.S. After Japan's sovereignty was restored in 1952, Japan joined the World Bank, which provided Japan with nearly $\$ 1$ billion in aid from 1953 to 1966 . While this aid was used for many revitalization projects, emphasis was placed primarily on infrastructure development (Feasel 2015, 11-13). From 1956 until 1970 the U.S. Export-Import Bank also provided nearly \$1 billion in long-term loans (Feasel 2015, 13).

In 1954, while Japan was still a recipient of development aid, it began venturing into the role of offering economic assistance on a limited scale by contributing $\$ 50,000$ to the Colombo Plan (Söderberg 2017, 5). At the time, only ten states were party to the Colombo Plan, including the U.S., Indonesia, Pakistan, and India. It was a small step, but one which helped reintroduce Japan into participation in regional organizations (Yanagihara and Emig 1991, 37). Around the same time, Japan began war reparations negotiations with Burma, the Philippines, and Indonesia. While the reparations were intended to provide compensation for infrastructure damage incurred during the war, 
Japan had crafted the reparations with a dual purpose so they were also directly tied to the export of Japanese products; "although it was labeled war compensation, it was also a way for the Japanese government to rebuild its own industry through promotion of exports" (Söderberg 2015, 152). The money paid in "reparations" went into financing Japanese investments and exports to these nations (LaFeber 1997, 310). As Feasel argues, "[w]hat Japan soon realized is that rather than being an economic burden the reparation payments opened up the markets in these countries to its own exports, something the countries would have been highly resistant to given the recent history of the war at the time" (2015: 48). This would have tremendous outcomes beyond seeking justice for the wartime invasions. This move opened markets in Southeast Asia to Japanese manufactured exports long-term, and also started the concentration of Japan's development assistance (although they were not calling it that at the time) on Asia (Yanagihara and Emig 1991, 37).

The first yen loan within the rules of the World Bank was offered to India in 1958, and a similar yen loan was provided to Pakistan in 1960 (Yanagihara and Emig 1991, 38: Feasel 2015, 50). In 1960 Japan was a founding member of the OECD Development Assistance Group (later Committee) (DAC), and was admitted into the OECD itself three years later. Japan had also just joined the IMF a few years prior, and membership in these institutions both fortified its postwar role among the "rich donors' club" and forced its development assistance to meet a set of international standards (Söderberg 2017, 1). There were no misgivings about the nature of these loans; the Japanese preferred to call them "economic cooperation" rather than "aid," and they were clearly laying groundwork for Japanese exports, and later FDI, into the markets 
(Yanagihara and Emig 1991, 38). By the late 1960s, most of Japan's ODA was no longer in the form of reparations, and together with the U.S., Japan founded the Asian Development Bank (ADB) in 1966, with each country putting up \$200 million (Feasel 2015, 49).

Throughout the 1960s, Japan's development assistance was exclusively to east and southeast Asian states, serving the dual purpose of assisting in development, but also opening up export markets, but this would soon change with the new decade. The 1973 oil crisis forced Japan to broaden its geographic scope of aid recipients to include Arab states, and illustrated a shift in the utilization of the aid tool from export promotion to resource security (Yanagihara and Emig 1991, 41). The use of development assistance as a foreign policy tool had veered from geo-economic interests to geopolitical interests. Geoculture, while always imbedded in foreign aid decisions, would not overtly appear until 1978, when humanitarianism was first mentioned as a purpose for development aid (Söderberg 2017, 5). After the 1973 oil crisis, Japan adopted a loose, unofficial policy to distribute its ODA at 70:10:10:10, with 70 being 70 percent to Asia, and 10 percent to Africa, the Middle East, and Latin America, respectively (Söderberg 1996, 34-5). In 1974, the Japan International Cooperation Agency (JICA) was created as the principal agency that oversees dispersal of ODA, and has facilitated more technical assistance and training in addition to the yen loans that seemed to dominate the Japanese style of development assistance. ODA grants have also increased, albeit, still much lower than yen loans. The total volume of ODA expanded tremendously with the economic growth and appreciated yen in the late 1970s and 1980s. Between 1973 and 1978, net disbursements doubled; between 1978 and 1980, they doubled again (Yanagihara and 
Emig 1991, 41). During the decade of the 1980s, Japan's ODA nearly tripled, and continued to increase until it peaked in 1995 at nearly $\$ 14.5$ billion in net disbursement. In that year, Japan's net total ODA was nearly double that of the second-largest donor nation, France, at $\$ 8,439$ (in USD value) (MOFA 1997). While Japan's net total ODA disbursements have remained among the highest in the DAC, it was surpassed in annual net disbursement by the U.S. in 2001, and more recently by the UK and Germany. It should be noted that all comparative figures are given in U.S. dollars, and thus subject to exchange rates at the time, but this too, is reflected in the ODA disbursement decisions in each year.

\section{Characteristics of Japan's ODA}

Some have criticized Japan's ODA activity as being the outcome of pressure from Washington: "[t]hat there has been Japanese cooperation is more a reflection of Tokyo's desire to mollify the U.S. than any effort to pursue an expanded foreign policy agenda"

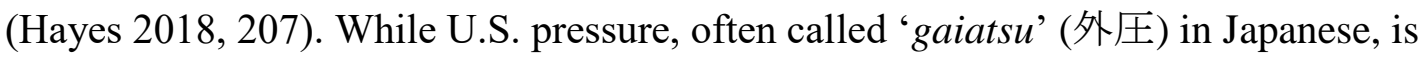
indirectly a factor which brought Japan into the role as a donor-nation, the above statement is an exaggeration of American influence. In fact, Japan's ODA policy has done much to strengthen its soft power stature around the world, and Japan has benefitted for years from "the appearance of a responsible country with a strong social conscience" (Söderberg 2017, 5). While true, Japan's development assistance has actually hovered well below the DAC average when considered as a percentage of gross national income (Söderberg 2017, 6). Moreover, its aid programs have never been particularly supported or even well understood by the domestic public (Söderberg 2017, 6). 
There are some characteristics of Japan's form of development assistance which distinguish it from other donor-nations. First, to make yen loan arrangements transparent, recipient states must request aid for a specific project (Feasel 2015, 19). ${ }^{1}$ Because of this practice for requests, most of Japan's ODA is provided bilaterally, much more so than the average of donor states (see Table 6.1 for bilateral ODA dispersements) (Donor Tracker 2018). Moreover, Japan tends to focus on infrastructure development projects for its yen loans - usually, this is transport infrastructure such as roads, railways, ports and power plants, and communications infrastructure (Söderberg 2017, 6: Yanagihara and Emig 1991, 46).

Secondly, there is a notably heavy reliance on loans for ODA, rather than grants. ${ }^{2}$ Fifty-eight percent of Japan's bilateral ODA in 2015 was in loans, while the DAC average was just ten percent (Donor Tracker 2018). Japanese ODA policymakers call this "help to self-help" (enjo kara, jijo e), because a recipient should be able to use the aid by investing in something which contributes to economic growth, and thus, should have the capacity to pay off the loan and continue benefitting from the investment long-term. Ideally, countries are expected to 'graduate' from ODA-recipients to dynamic trade partners. While the emphasis on loans has garnered criticism from other donor-states, and naturally grants are preferred over loans by recipients, some scholars of ODA have noted that loan aid "helps the recipients foster a credit culture, moral principles and discipline as borrowers" (Takahashi and Owa 2017, 26). To be clear, yen loans tend to have

\footnotetext{
${ }^{1}$ In reality, requests by recipient states often come from suggestions made by JICA staff, but this is often out of procedural knowledge, and does not necessarily interfere with the need for transparency (Feasel 2015, 79).

${ }^{2}$ See Table 6.2 for bilateral grant recipients as of 2015 .
} 
comparably low interest rates and extended grace periods, but there is a striking distinctiveness regarding this expectation of repayments by Tokyo that is not seen to the same degree by other donor nations (Donor Tracker 2018).

Feasel makes the point that Japan's self-help perspective and high utilization of yen loans for development aid is partially rooted in its own postwar experiences, but it is also rooted in the fact "Japan does not have the Judeo-Christian tradition or the missionary history where aid and charity for less developed nations or less fortunate individuals has strong historical precedents" (2015: 38). This might be a superficial understanding of the norms and values of a donor state, but Sawamura argues poignantly "the Japanese people believe that most other bilateral donors have a tradition of Christian beliefs," and with that understanding they seek to base their ODA philosophy on their own unique experiences (2004: 29). To that end, Japanese political elites frequently speak of Japan's rapid modernization during the Meiji Period, especially in recipient states, as a model for development based on "help to self-help."

Despite garnering occasional criticisms, Japanese ODA practice follows along with the Japanese cultural practice of okaeshi (お返し), which is the etiquette of giving whereby reciprocation by the receiver is understood as obligatory, but in due time. It also relates to the concept of on (恩), which is a favor, but also implies an indebtedness, not exclusively a financial indebtedness, but one of a karmic sense. ${ }^{3}$ The two terms can be combined to form ongaeshi (恩返し), or the return of a favor out of gratitude. It carries an emotive nuance that is absent in okaeshi. Many learn of the concept from a popular

\footnotetext{
${ }^{3}$ It is also expressed as hōon (報恩), a term more widely known as Boeun, a key tenant of the Jeungism religious movement in Korea.
} 
folklore tale with Shinto undertones, Tsuru no Ongaeshi (The Crane's Return of Favor). After the March 2011 earthquake in Eastern Japan, the Iraqi government offered \$10 million in disaster relief aid (Miyata 2017, 79). When asked about the substantial contribution from a country struggling with its own war-torn reconstruction, a member of the Iraqi federal parliament noted that "this is a return of gratitude for what Japan has done for us up to now," clarifying that it was an act of appreciation for what Japan did in terms of reconstruction assistance after the Iraq War (Miyata 2017, 79). The statement was translated in Japanese as ongaeshi. This illustrates a difference in understanding in the value of charitable giving between the West and Japan, but also, and more importantly for this project, it relates to Japan's understanding of development aid, and the Islamic practice of prohibiting riba, or usury, which is discussed in the following section.

A third characteristic of Japan's ODA is a characteristic that was evident from the very beginning yet persists: ODA is often set up contractually in a way as to enable private sector engagement. Thus, ODA is deliberately designed to open doors for FDI and an export market. Japanese development aid has a category separate from ODA called Other Official Flows (OOF), which are credits below market price. Then, private investment tends to come in after this (Söderberg 2017, 3). The OOF and private investment tend to be included in Japan's development aid data, but not used internationally, although DAC's revision to their definition of development assistance has allowed for some of these to be taken into consideration in their figures as well (Söderberg 2017, 3). 


\section{Development Assistance Charters}

In 1992, an ODA Charter was announced by then Prime Minister Kaifu Toshiki.

The charter put geoculture at the forefront of Japan's ODA initiatives. The principles of the Charter were listed as follows:

1. Environmental conservation and development should be pursued in tandem. 2. Any use of ODA for military purposes or for the aggravation of international conflicts should be avoided.

3. Full attention should be paid to trends in recipient countries' military expenditures, their development and production of weapons of mass destruction and missiles, their export and import of arms, et cetera, so as to maintain and strengthen international peace and stability, and from the viewpoint that developing countries should place appropriate priorities in the allocation of their resources in their own economic and social development.

4. Full attention should be paid to efforts for promoting democratization and the introduction of a market-oriented economy, and the situation regarding securing basic human rights and freedoms in the recipient countries (MOFA 1992).

With regard to regions, the Charter states:

Historically, geographically, politically and economically, Asia is a region close to Japan. East Asian countries, especially member countries of ASEAN, constitute one of the most economically dynamic regions in the world, and it is important...to sustain and promote the economic development of these countries. There are, however, some Asian countries where large segments of the population still suffer from poverty. Asia, therefore, will continue to be a priority region for Japan's ODA (MOFA 1992).

The Charter coincided with the end of the Cold War, and the creation of new post-Soviet states in Asia, as well as with the end of the Gulf War. It also, however, coincided with the post-bubble economy in Japan. While the malaise persists today, it is important to bear in mind that in 1992 it was widely assumed to be a short-term lapse in economic growth, and this 'optimism' is reflected in the language found in this document. In light of the persisting new economic uncertainty, the Japanese public became less interested in its role as a major global aid donor during the 1990s (Söderberg 2017, 6). Nonetheless, 
Japan would remain the largest single source of ODA in the world from 1989 until 2001 (Hayes 2018, 207-08).

In 2003, Japan revised its Charter to emphasize peace-building. It states "[ $\mathrm{t}] \mathrm{he}$ objectives of Japan's ODA are to contribute to peace and development of the international community, and thereby to help ensure Japan's own security and prosperity [italics added]" (MOFA 2003). In other words, something is overtly expected in return (okaeshi) for the ODA contributions. There may have never been any pretenses to altruism, but here the point is clear a positive sum outcome is expected, and what Japan gets out of the outcome is articulated.

Reflective of the change in times since 1992, another noteworthy point about the revised Charter is the utterance of a particular word six times which was never mentioned in the 1992 version: terror. It states:

conflicts and terrorism are occurring more frequently and they are becoming even more serious issues. Preventing conflicts and terrorism [italics added], and efforts to build peace, as well as efforts to foster democratization, and to protect human rights and the dignity of individuals have become major issues inherent to the stability and development of the international community. Japan, as one of the world's leading nations, is determined to make best use of ODA to take the initiative in addressing these issues (MOFA 2003).

The four principles remain mostly the same at the 1992 Charter, but notably, in the third principle, "including the prevention of terrorism and the proliferation of weapons of mass destruction" is added in the list of conditions to be considered for recipient states (MOFA 2003). The revised Charter also mentions an objective not mentioned in the initial one: “assuring Japan's security and prosperity," an unmistakable enunciation linking security of the state to development assistance abroad (MOFA 2003). The revised charter is also much more detailed than the first, and calls for broad participation by Japanese citizens, 
as if offering to deploy them as part of a securitizing sector, which is not mentioned in the initial Charter. The revised Charter starts with almost a self-congratulatory tone: "Taking advantage of Japan's experience as the first nation in Asia to become a developed country," and "Japan has significantly contributed to the economic and social development of developing countries, especially in East Asia" (MOFA 2003). It reiterates Japan's regional emphasis on Asia, but addresses a need to broaden its target region from Southeast Asia: “Also, Japan will give due consideration to the large population of impoverished people in South Asia. With respect to Central Asia and the Caucasus region, assistance will be provided to promote democratization and transition to market economies" (MOFA 2003).

In February 2015, Tokyo announced a third Charter which removes references to ODA altogether and instead uses "development cooperation." This indicates movement back to the original language of "economic cooperation" used in the late 1950s when development assistance first began (Söderberg 2017, 9). It also deliberately indicates a desire to "cooperate" with Japanese non-governmental organizations (NGOs), in an attempt to blur the lines between state-level assistance and that which comes from private organizations in Japan. Private Japanese NGOs have become increasingly dynamic since the 1995 Kobe earthquake and 1998, when a law was passed in the Diet that relaxed the regulations for volunteer organizations to incorporate. Since then, Japanese NGOs have become a major force in disaster relief after natural disasters overseas and the 2011 Tōhoku earthquake and tsunami, and humanitarian aid during and after the wars in Iraq and Afghanistan. A major Japanese NGO active in Muslim Asia is the Japan International Volunteer Center, with community health and education projects in Gaza, Kirkuk, Phang 
Nga Province (a Muslim-majority area in southern Thailand), and several locations in Afghanistan. Another is the Japan Iraq Medical Network, which provides medical assistance for children in Iraq and Syria. Despite being non-governmental, the government tends to be a significant funding source for NGOs, primarily through grants and subsidies by MOFA, JICA, and prefectural and local governments.

The third charter states that "Japan will provide more focused cooperation in a strategic, effective and agile manner," which indicates a sort of justification for making ODA more selective and austere amid the domestic economic and societal concerns. It adds "Japan will extend necessary cooperation to countries based on their actual development needs and affordability" (MOFA 2015b). Regionally, the Charter reiterates that Asia maintains the geographic focus, stating "Asia is a region that has a close relationship with Japan and high relevance to its security and prosperity" (MOFA 2015b). While more detail is added to the regions in the 2015 Charter, there is nothing to reflect a change in priority. As with the 2003 Charter, Southeast Asia is listed as the first region (and most detailed), followed by South Asia, Central Asia and the Caucasus. The Middle East is discussed after Africa in both charters. Mention of "terror" is decreased to only three times in the third Charter, while the utterance of "environment" went up from seven times in 2003 to 15 in 2015 . From the 1991 Charter, to 2003, to 2015, gradually ODA is becoming linked to values, such as democratization, human rights, and regional stability (see Table 6.3).

The evolution of making ODA a foreign policy tool has been met with some resistance in Japan. Horie warns that politicizing humanitarian assistance is very risky, given Japan's contribution in this field is not all that substantial, and can only result in 
animosity (2016: 151). In a sense, the risk is understood, but this is a misinterpretation. It is nothing new that ODA is being tied to Japan's national interests, but these national interests are shifting to link ODA not only to geoeconomics, but also geopolitics, and more firmly (overtly) to geo-culture. One should not assume that advocating democratization and human rights is for geopolitical interests. It may be done to appease Washington, but it appears as if the Trump administration cares little about these issues in Asia. It may also be to distinguish Japan from China, but it is hardly a carrot to consider for potential aid recipients when China is offering so much more in its AIIB and One Belt, One Road Initiative (BRI). The application of these values in strategy is discussed further in the following chapter.

ODA decisions, nonetheless, are undoubtedly connected to domestic politics in Japan, as they are also connected to exogenous variables of the time. In Japan, MOFA is in charge of designing policy, but it does not have the authority, however, to offer any loans without cooperation with the Ministry of Finance, currently headed by Deputy Prime Minister (and architect of the Arc), Asō Tarō. The Ministry of Finance, however, cannot issue all loans, but rather, must receive approval from the Diet for all budgetary matters. Both MOFA and the Ministry of Finance have LDP politicians at the top, and bureaucrats who control the bulk of operations. Any ODA decision is delegated for implementation by JICA. This includes loans, grants, and technical cooperation. For technical cooperation, JICA often dispatches Japan Overseas Cooperation Volunteers (JOCV) to developing countries, in programs that mirror the Peace Corps in the U.S. Increasingly, JICA collaborates with Japan-based NGOs, as implied in the 2015 charter. 


\section{Riba, Yen Loans, Morality, and Normativity}

Islamic banking is based on the principle of profit and loss sharing. Thus, rather than charge interest on loans, Islamic banks participate in the yield that results from loans, together with the borrowers. Thereby, a partnership is formed. The main justification for Islamic banking is the moral prohibition of riba, as cited in the Qur'an. In conventional banking, riba is associated with drawing interest, in thus, usury. This idea of money breeding money is long-held as an immoral offense found in the writings of a wide range of classical jurists (Tripp 2006, 66). There remains ambiguity, however, regarding the extent to which 'interest' directly translates to riba, as some notable Muslims have argued a reasonable application of interest is acceptable within moral limitations while others condemn all forms.

The morality in both Islamic banking and Japan's yen loans has also interacted with another method of moral-based banking that originates in Muslim Asia: microfinance. Bangladeshi economist Muhamad Yunus founded the Grameen Bank of Bangladesh in 1976 based on the principals of microfinance, which earned him the Nobel Peace Prize in 2006. Microfinance differs from conventional banking because it aims to provide loans to the poor, who have no collateral or credit. With loans no more than $\$ 120$, the poor in Bangladesh are able to make a practical investment which would draw a larger return. For example, someone could use the loan to purchase a sewing machine to start a textiles trade, or a cow for milking, or a cellular phone. Loans are overwhelmingly given to women, who repay their loans in person, together with other borrowers, which creates an accountability system. While there are characteristics of Yunus's microfinance concept which are shared with both Japanese yen loan practices and Islamic banking, it 
has also received considerable criticism from the latter. Bangladesh is a Muslim-majority country, and Yunus is a practicing Muslim, but Grameen Bank is not shari' $a$-compliant since it charges interest on loans and pays interest on deposits (albeit, simple interest and not compounded interest). The normative basis for Japanese yen loan distributions based on 'help to self-help' are also seen in microfinance, where Yunus argues that charity to the poor only leads to dependency and lack of inducement (Abdul Rahman 2007, 39). Moreover, both intend to offer loans designed for revenue-generating ventures. Yunus is familiar with Japanese business practices, and even joined the Grameen Bank together with Japanese clothing retailer, Uniqlo, in 2011 for a joint venture textile company in Bangladesh called Grameen JV (Pesek 2014, 130).

What microfinance shares with Islamic banking is firstly, their shared criticism that conventional banking is immoral, as both emphasize the borrower as the poor, and an obligation to protect and assist the poor. Secondly, there are effective, yet differing accountability mechanisms in both systems. In microfinance, an accountability mechanism is created in the communal responsibility of the recipient group. If one member of the recipient group cannot follow through with repayment, she must surrender membership to the bank, as does everyone in the group. Thus, there is a strong incentive program for individuals to not let down their group peers, and if they do, there is an incentive for the group peers to fill in and repay on behalf of the delinquent individual (although they are not explicitly required to do so). In Islamic banking, the accountability mechanism is created between the lender and borrower in profit and loss sharing arrangements, which incentivizes each to be fair with the other and pragmatic with the decision for the loan to take place. 
As noted in the previous chapter, Islamic banking practices have appealed to nonMuslims in Southeast Asia, such as ethnic-Chinese. In many ways, the moral values emanated through Islamic banking share much with the moral values which dictate the "help, to self-help" approach to development aid. As mentioned earlier, Japanese yen loans do charge interest, but with relatively generous conditions. For the least developed countries, according to the most recent terms and conditions, yen loans can be as little as 0.1 percent interest at a fixed rate, with a maximum ten-year grace period, for forty years of repayment. Terms and conditions are stricter with countries categorized as more developed, but rarely does the interest rate exceed one percent (JICA 2017). Points of concern exist, however; Japan could conceivably draw exorbitantly more interest if, over time, the yen appreciates to the local currency, which would be seen as highly immoral. Moreover, Japan often works in a clause to its yen loan contracts that 30 to 50 percent of investment contracts must be awarded to Japanese companies, as it is viewed as the start of a long-term relationship between the two.

Japan's approach to its yen loans is based on its values system predicated on ongaeshi in giving, and this is reinforced by its own historic experience as a loan recipient who transitioned successfully from 'help, to self-help.' Thus, the normative implication is that recipients of Japan's yen loans are both capable of, and responsible for achieving development as Japan had done. Islam teaches differently regarding giving, but there is a clear compatibility between the two views. Both yen loans and Islamic banking induce the lender to maintain a vested interest in the actual achievement progress of the borrower, and thus, both can facilitate for strengthening long-term ties through the 
lending transaction. The following section explores the longest of those ties, between Japan and Muslim Southeast Asia.

\section{Southeast Asia: The First Recipients}

Postwar, Muslim populations in Southeast Asia were, with reason, hesitant to reestablish economic relations and deepen trade ties with Japan. As mentioned in the previous chapter, this was something the Japanese have been able to gradually overcome with more success than in Northeast Asia. One possible reason is because the Southeast Asian experience of Japanese colonization was much briefer than the Northeast Asian experience, making up no more than four years in any given part of Southeast Asia. Thus, in China and Korea, there is a longer record of invasion, occupation, and subservience in the historical memory. Moreover, there is an understanding that Japan's invasion and short occupation of Southeast Asian territories was an inadvertent critical juncture in their histories by displacing Western powers, and thereby perpetuated the causal chain of events that singled out national heroes, and led to national independence for these states. In the case of Indonesia, after Japan's surrender in August 1945 thousands of Japanese soldiers trained or even joined local forces to fight the Dutch when they inevitably returned (Tjandraningsih 2009). ${ }^{4}$

Thus, in the immediate postwar years, there was naturally a suspicion regarding Japan's potential and hegemonic ambitions in the region, but it did not persist as it does

\footnotetext{
${ }^{4}$ Another reason amends could progress easily with Indonesia was on account of a quasi-diplomatic marriage. Just after diplomatic relations were established in 1958 between Indonesia and Japan, in 1959 Indonesian President Sukarno wed a 21-year old Japanese actress, Nemoto Naoko. Nemoto changed her name to Ratna Sari Dewi, took Indonesian citizenship, converted to Islam, and with her popularity played a significant role in restoring a positive image of Japan for Indonesians, and convincing Sukarno to develop a trusting relationship with Japan. Even as Sukarno became more autocratic and distanced himself from the U.S. in the early 1960s, he was simultaneously building closer relations with Japan.
} 
today in Northeast Asia. As argued by Hayes, "[r]eparations were paid to some [Southeast Asian] countries... while agreements were reached with other countries under which they would receive quantities of capital goods," thereby "[t]hese agreements helped smooth the way to the opening and development of markets in south-east Asia" (2018: 196). It has not been entirely smooth, however. The previous chapter discussed the 1974 Malari Incident, sparked by concerns in Jakarta over multiple grievances including Japanese 'economic imperialism' and insensitivities to local needs. Yet, ODA has served as a specific tool to placate such complaints.

Indicators show a tremendous change since the Malari Incident. Indonesia has been the single largest recipient of Japanese ODA (Feasel 2015, 50). Between 1960 and 2011, Indonesia received \$36 billion from Japan in aid, far surpassing the second greatest donor, the U.S., at $\$ 7$ billion, total (Feasel 2015, 55). Singapore and Brunei were also once recipients of Japan's ODA, but have since 'graduated' from the program. In 1982, Malaysian Prime Minister Mahathir Mohamad launched the 'Look East Policy,' which called for the emulation of Japan's economy and attracting Japanese capital to Malaysia. Japan eagerly welcomed the policy, increasing its ODA to, and FDI in Malaysia. In 1986, Mohamad brought in Japanese advisors to the Malaysian government for implementing an industrialization plan, much as Japan had done with Western advisors in the late nineteenth century. ${ }^{5}$ The policy received renewed vigor when Vision 2020 was announced by Mohamad in 1991. There are inevitable trade issues, and increasingly so as

\footnotetext{
${ }^{5}$ Skilled advisors from Europe and the U.S. called oyatoi gaikokujin (お雇い外国人) were hired by the Meiji government for technology transfer in order to speed up the modernization process in Japan.
} 
both countries are leading the effort to persevere with the CPTPP, but an openness to deepen economic and cultural relations is seen on both sides.

The previous chapter shows Indonesia and Malaysia are Japan's two biggest Muslim export markets, and both are significant destinations for Japanese FDI today. Favorability surveys conducted in 2015 showed 71 percent of Indonesian respondents had a favorable view of Japan while 13 percent had an unfavorable view (Stokes 2015, 14). In Malaysia, 84 percent had a favorable view while 9 percent had an unfavorable view (Stokes 2015, 14). In fact, the Malaysian view of Japan was even higher than the Japanese view of themselves in the same survey, as Japanese showed an 82 percent favorable view and 15 percent unfavorable view of their own country (Stokes 2015, 14)! Insofar as soft power and export markets are objectives of Japan's ODA, Southeast Asia is a success story. On top of this, if making amends with wartime occupation was an additional objective unique to Northeast and Southeast Asia, the objective was mostly achieved in the latter while hardly so with the former.

\section{Central Asia: A 'New Asia'}

The end of the Soviet Union and subsequent creation of independent republics in Central Asia have offered Japan an opportunity to explore its role in Asia as a state that offers development aid. Once glasnost-based policies in the Soviet Union allowed for greater freedom of information in the late 1980s, Japanese scholars had more opportunity to conduct research in Central Asia, which was met by romanticized notions of the Silk Road by the public. Learning of the Silk Road transmission of Buddhism through Central Asia, people were drawn to Orientalized notions of the region, but rather than draw distinctions, they found ways to connect with it. Scholars and pseudo-scholars touted 
cultural similarities, and highlighted a plausible, but not well supported linguistic theory that the Japanese language belongs to the same Altaic language family as the Turkic languages spoken throughout Central Asia, except Tajikistan, and in Azerbaijan, Turkey, and among Russian Tatars. The linguistic theory is mostly discredited today, yet it provides a geocultural narrative for Japan's curiosity about Central Asia, as a 'new Asia,' where Japan can assume itself a 'role model,' and do so without the historical baggage it carries in Northeast and Southeast Asia. Moreover, it interestingly provides the Japanese with a geocultural tool to unite with a broader segment of Asia, yet a fraternity that is exclusive of Han Chinese, according to the ethnolinguistic theory. Another interesting point about constructing a geocultural relationship with Central Asia is how it conflicts with a simultaneous narrative in Japan known as Nihonjinron, which emphasizes Japanese exceptionalism and uniqueness. Rather, in this case, Japan is straining to relate itself to a new Asia.

Over a quarter century after independence, ODA remains the only robust connection between the Central Asian republics and Japan. The republics have remained a fraction of a percent of Japan's global exports markets and FDI destinations, the muchtouted energy resources in Central Asia hardly make their way to Japan, and interpersonal relations are constrained by lack of transactional opportunities (Barber 2018, 34-35). ODA, however, has been consistent, and a revealing facet to Japan's ODA strategy as it relates to conceptualization of Asia, Islam, and its own role.

In 2006, Asō explained the motivation behind Japan's involvement in Central Asia: 
if you think of a chain, you can realize that if a single link is weak, it doesn't matter if the rest of the chain is sturdily constructed. It is the strength - or, more accurately, the weakness - of that single link that determines the strength of the entire chain, and this is essentially how Japan perceives this issue (2006a).

He adds:

The countries of Central Asia have historically had a large number of secular Muslims. However, in recent years we have repeatedly been made aware of Islamic extremism permeating into the area from the south and the west. In the battle to prevent terrorism, which uproots world order and stability, there is simply no way around the task of patiently going about strengthening weakest links (2006a).

Obviously, Asō makes a distinction within the realm of "Islam": "secular Muslims" (sezokutekina isuramu-kyōto) and "Islamic extremism" (isuramu kagekishugi). Also interesting is the securitization framing: the 'Islamic extremism' is an invasive threat, "from the south and the west." This is a securitization speech act, with Asō, the securitizing actor, Islamic extremism from the south and the west the threat, and Central Asia is the referent object, as the "weakest link." This characterization by Asō creates a clear image of multiple zones of Islam across Asia and incorporated into the Arc. Moreover, it is also revealing of Japan's strategy for this security threat: strengthen the weakest link of the chain by aiding Central Asia with development.

\section{Japan Centers}

Japan Centers are ODA hubs specifically located in countries transitioning from planned economies to market economies. Started in 2000, Japan Centers are located in nine countries in former Soviet republics, mainland Southeast Asia, and Mongolia. In Central Asia, there is a Japan Center in Bishkek, Tashkent, and Almaty (with a branch 
office in Astana). ${ }^{6}$ The Japan Centers are managed by JICA, and adhere to its ODA Charter. Japan Centers "offer training that focuses on management know-how and knowledge that are traditional strengths of Japanese business" (JICA 2012). The Japan Center boasts in its own literature that their trainees include "executives who used Japanese production management techniques to expand their businesses and entrepreneurs who relied on Japan Center's training to develop their business model" (JICA 2012). A normativity is clear in this approach which exemplifies Japan's view of how development is to take place, and beyond this, it relates directly to access to markets and democratization. It is a display of liberal normativity usually associated with the West, and an example of Japan defying its own proclivity toward an identity based upon uniqueness, and thus defying Nihonjinron. Japan is admitting its model is replicable and of all places, replicable in landlocked, resource-rich, sparsely-populated societies of Muslims. Cultural, geographical, historical, and developmental indicators all show great differences with Japan, yet perceptions highlight the similarities.

\section{ODA and Securitization of Islam}

Japan's decisions in ODA disbursement are always tied to the geocultural, geo-economic, and geopolitical motivations for foreign policy engagement, but certain events in Muslim

\footnotetext{
${ }^{6}$ Japan Centers differ from the locations of the Japan Foundation, which is a state-sponsored, autonomous cultural promotion organization similar to China's Confucius Institute and the UK's British Council. The Japan Foundation has 23 locations abroad, but among the ten in Asia, only Jakarta and Kuala Lumpur are cities (and countries) with Muslim majorities. There is a clear dearth of Japan Foundation locations in Muslim Asia. Nagasawa and Nukii (2015) of JIIA argue in comparison to the West, Russia and China, "Japan's strategies to publicize its culture are clearly inferior"; therefore, "more Japan Foundation offices should be established, to supplement its sole regional office in Cairo as a way to cultivate pro-Japanese opinion leaders and improve Japan's image in the Middle East" (236). They go on to suggest locating new offices in Dubai, Tehran, and Istanbul (236). Japan Foundation focuses on the dissemination of a cultural message, and the deliberate crafting of soft power by means of attracting interest in language, culture, and the arts. Japan Centers, on the other hand, have a more practical application that relates to development and Japanese norms of business and market operations.
} 
Asia have resulted in Japan withdrawing its planned ODA disbursement due to perceived security threats from religious terrorism. Paradoxically, it is often precisely these states where the security threats emerge which are most in need of Japan's ODA. Three cases, the Bangsamoro Autonomous Region in the Philippines, Syria, and Bangladesh are selected here because all were sites of ISIS terrorist events that occurred in a span of less than three years, yet the three cases resulted in very different policy decisions by Tokyo. Through examining the three, a better understanding of how Islam is securitized by Tokyo is attained.

\section{Bangsamoro}

In the Philippines, Japan's ODA has been particularly active in the Muslim Mindanao region. While Muslims make up less than six percent of the population in the Philippines, Muslims have lived in the western parts of the southern island, Mindanao, since before the arrival of the Spanish in the sixteenth century. The Spanish called the Muslim Filipinos 'Moors,' from which their current name, 'Moro,' is derived. There has been an ongoing negotiation for the creation of an autonomous region in western (Muslim) Mindanao to be called Bangsamoro, but has been stalled due to resistance from independence movements among some Moros, attempts at a federal arrangement by President Rodrigo Duterte, and violence from pro-ISIS militants.

Muslim Mindanao is the most impoverished region in the Philippines. During his first stint as Prime Minister, Abe announced the 'Japan-Bangsamoro Initiatives for Reconstruction and Development' (J-BIRD) in 2006, which launched Japanese engagement in the region. Under J-BIRD, Japan made stability and peace in Mindanao one of its three key objectives for ODA to the Philippines. In 2013, JICA negotiated for a 
Comprehensive Development Project with the Moro Islamic Liberation Front's Bangsamoro Development Agency, notwithstanding the fact the political entity had not officially come into existence yet. While the implementation of Bangsamoro as an autonomous region has been stalled, Tokyo's decision to proceed with the Comprehensive Development Project with a political entity in-waiting is a remarkable and uncharacteristic engagement by Tokyo in an issue that is both politicized and securitized within domestic politics in the Philippines. Subsequently, Japan focused disproportionately a significant amount of its ODA activities in the Philippines - the second greatest recipient of Japanese ODA - on the Muslim Mindanao region. On MOFA's Japanese-version website, it explains that it seeks to provide aid at various levels so the new autonomous government "will build trust from the populace" (MOFA 2015a).

Violence by pro-ISIS militants in Muslim Mindanao has stalled the implementation of the Bangsamoro Autonomous Region, and stalled opportunities for economic development. In 2017, there was a five-month-long conflict between a pro-ISIS militant group and the Filipino military in the city of Marawai, resulting in over a thousand dead, including 87 civilians. Yet interestingly, there is no indication of securitization by Japan. Japan has remained focused on its aid program in Muslim Mindanao, and still dispatches JICA employees and contractors to the region. Progress has stalled, yet Japan's role as a primary ODA donor to the region has remained constant.

\section{Syria}

In late January 2015, two Japanese men were separately kidnapped in Syria and offered for a $\$ 200$ million ransom by ISIS. The ransom video was addressed directly to 
Abe: "You have proudly donated $\$ 100$ million to kill our women and children, to destroy the homes of the Muslims... and in an attempt to stop the expansion of the Islamic State, you have also donated another $\$ 100$ million to train the apostates" (Sugawara 2015, 45). When the Japanese government refused to pay the ransom, the two were executed. ISIS linked this occasion with Japan's aid. Just two days prior to the ransom message being broadcast, Abe was in Egypt where he announced,

In order to help reduce the threat ISIL poses, we will offer our support to Turkey and Lebanon and also provide aid to the refugees and displaced persons of Iraq and Syria. To those nations battling with ISIL, we pledge a total of $\$ 200$ million [italics added] to aid in the development of human resources and infrastructure (Sugawara 2015, 46).

The $\$ 200$ million value is conspicuously the same as the ISIS hostage takers' ransom request. One could assume Japan was not so much a target, but rather, a timely opportunity for extortion fell into the hands of ISIS, and not true enmity specifically towards Japan. ${ }^{7}$ During the execution of the second hostage, the ISIS member made an ominous threat, "let the nightmare for Japan begin!" Interestingly, however, the Japanese public responded to the event and its outcome by blaming the victims for causing distress to the country, and unwisely placing themselves in danger (Spitzer 2015). In fact, the number of non-Muslim Japanese visiting mosques in Japan simply out of curiosity increased after the incident (Yamagata 2017, 13). This clearly illustrates a case of Islam not being securitized, at least among the public, since people wanted to learn more about the religion as it came to the forefront of social consciousness.

\footnotetext{
${ }^{7}$ One of the hostages, Gotō Kenji, was a Japanese Christian, but there is no evidence this was apparent to the ISIS kidnappers, or whether it would have had any bearing on their decisions.
} 
There was, however, the inevitable securitizing carried out by the political elites. Abe's financial pledge notwithstanding, the event highlighted the awkwardness of Japan's Middle East foreign policy. Just weeks after the murder of the second Japanese hostage (and one week after the announcement of the revised Charter for Development Aid), Foreign Affairs Minister Kishida Fumio announced a new three-pillar response in regard to the executions: (1) strengthen counter-terrorism measures; (2) enhance diplomacy toward stability and prosperity in the Middle East; and (3) assist in creating societies that do not give rise to radicalization (Kishida 2015). The announcement included $\$ 15.5$ million in assistance to building counter-terrorism capacity in the Middle East region, in addition to raising Abe's declared \$200 million in humanitarian assistance to an unspecified larger amount (Kishida 2015). Moreover, Kishida included the goal to expand interpersonal exchanges "including inviting religious leaders" (Kishida 2015). The goal of adding religious leaders clearly illustrates the understanding of the terrorism problem as a religious problem, and it is very unlike Japanese diplomats to even utter "religious" in foreign policy statements. The linkage of religion is reinforced in the statement by recommending a "coordination with ASEAN" to "promote moderation" (Kishida 2015). In other words, ASEAN has the model Muslims, who with Japan's decades of development assistance, have proven successful.

\section{Bangladesh}

In July 2016, a hostage crisis took place in Dhaka, Bangladesh when five men took over a busy cafe targeting non-Muslim foreigners. The 22 civilians who were killed included seven Japanese nationals - all of whom were JICA consultants conducting a survey of potential development assistance projects for urban transport in Dhaka. Less 
than a year prior to this incident, an elderly Japanese citizen working on an agricultural assistance project was shot in northern Bangladesh, with the Islamic State claiming responsibility. Bangladesh has been a key destination for JICA activities since 1973, and is the third largest recipient of JOCV, although after the October 2015 shooting, MOFA determined Japanese nationals were being targeted by terrorist groups in Bangladesh and ordered the return of all JOCVs.

The killing of the JICA consultants in Dhaka reinforced MOFA's stance, and no JOCV have been dispatched to Bangladesh since. The two incidents escalated the securitization of Islam through development aid activities, and ruined development assistance programs for people in need. In the aftermath of the hostage crisis in Dhaka, one of the individuals wanted for masterminding the event was Muhammad Saifullah Ozaki. To the shock of many in Japan, Ozaki was a Bangladeshi who went to university at Ritsumeikan Asia-Pacific University on a scholarship, earned his bachelors, masters, and doctoral degrees, obtained Japanese citizenship through marriage to a Japanese national, and was hired as an assistant professor of economics at Ritsumeikan University in Kyoto (Sasaki 2016). He came from a conservative Hindu family in Bangladesh, but converted to fundamentalist Islamic thought while living in Japan (Sasaki 2016). Ozaki, suddenly disappeared together with his wife and four children in January 2016 without word to his employer (Sasaki 2016). To date, Ozaki and his family have not been located. The killings and the Ozaki case raised concerns in Japan about how close it really is to ISIS threats, and elevated calls for action.

There are two poignant angles of securitization here. First is the perception that Japanese nationals - who were in Bangladesh for the purposes of development assistance 
- are targets. Precisely because these individuals were in the country for the purposes of development assistance, and they were targeted, according to MOFA, elevated the need for securitization. Secondly, however, it brought in a subversive domestic element, that a possible mastermind of the attack was a long-time resident of Japan, a representative of Japan as a passport holder, a respected member of his community as a teacher, and someone who was radicalized in Japan heightened awareness of terrorism significantly. Adopting the Buzan et al. definition of securitization, "the issue is presented as an existential threat, requiring emergency measures and justifying actions outside the normal bounds of political procedure" (1998: 23-24), one has to question a relationship between this case and the introduction of an anti-conspiracy law (kyōbōzai) by the Japanese Diet in December of that year. The anti-conspiracy law was passed in June 2017, and has garnered international criticism from many who claim it violates rights to privacy and it legalizes mass surveillance. The specified rationalization for the law mentioned by Abe was "to prevent terrorism before it happens" (Alberti 2017). While no public statement directly links kyōbōzai to the Ozaki search, the timing is noteworthy. Buzan et al. note the criteria for securitization: "[i]f by means of an argument about the priority and urgency of an existential threat the securitizing actor has managed to break free of procedures or rules he or she would otherwise be bound by, we are witnessing a case of securitization" (1998: 25). Legislation such as kyōbōzai had been attempted multiple times for years in the Diet, but failed. This one passed after 17 hours of debate (Alberti 2017). 


\section{Conclusion}

An examination of the distribution of Japan's ODA indicates the undeniable emphasis on Asia. The top nine recipients of Japan's ODA in 2015 were all Asian states, and five of the nine are Muslim-majority Asian states (see Table 6.1). Six Muslim Asian states have 'graduated' from being ODA recipients and no longer receive ODA from Japan. ${ }^{8}$ Others such as Kazakhstan, Turkey, and Malaysia may also 'graduate' soon, as well. A distinction can be noted regarding the dispatch of JOCV, however, between Muslim-Asia and what could be called Dharmic-Asia. While the dispatch numbers of JOCV are relatively few, as the key state-level representatives of Japan's development aid strategy, political calculations are an inevitable variable that determines the number of JOCV various countries receive. JOCVs in 2015 were dispatched to 20 countries total, and 18 of the 20 countries were in Asia. Only six of those 18 were Muslim-majority countries in Asia.

An Egyptian organizer for the first Japan-Arab Intellectual Exchange in 2006 stated, “Arabs must learn from Japan's successes, and Japan can learn from Arabs' mistakes" (Yamauchi 2006, 2). In response to this comment, Yamauchi fairly points out that "Arabs have not failed at everything, and Japan is not always an example of success" (2006: 2). Yet, the statement speaks of a certain reputation that has been cultivated. ODA has served as a tool for Japan's reputation, which is an essential part of the soft power Japan garners from these Muslim societies in Asia.

\footnotetext{
${ }^{8}$ These include UAE, Oman, Kuwait, Saudi Arabia, Bahrain, and Brunei. Qatar never was a recipient of Japan's ODA.
} 
ODA is inevitably tied to soft power objectives, and donors clearly want the recipient societies to know where the ODA originates. Japan is certainly no exception to this, and JICA and MOFA pay special attention to attitudes in ODA recipient countries toward Japan via periodic surveys. This is especially important in the pattern Japan has followed whereby ODA opens a door to FDI, which then opens a door to trade markets. Using a comparative statistical analysis on the correlation between ODA and recipient country sentiments toward donor countries, Feasel finds that overall "higher levels of ODA lead to higher sentiment levels toward the foreign governments" (2015: 153). He adds specific to the case of Japan, "the fact that it was the largest donor for most of the 1990s the good sentiment return from its relatively larger investment of ODA surely paid off dividends in helping to improve its reputation and standing in the world" (2015: 156). Indeed, there was a period of nearly two decades where Japan was the largest provider of development aid across Muslim Asia. The U.S. has surpassed Japan's development aid in Muslim Asia, but coupled with its hard power activities in the same regions, it has not garnered the same positive reputation as Japan. Sustaining this reputation will be challenging as Japan is shifting its ODA strategy from geo-economic interests to geocultural and geopolitical interests. The use of ODA in a carrot-and-stick approach could tarnish the reputation garnered.

Additionally, losing its position as a top donor will have its ramifications. Japan can continue to be a significant donor state, but its dominance as the primary donor in Asia is rapidly being overshadowed, not only by ODA from other DAC members (at times even including South Korea), but also from China. Beijing's BRI, and the AIIB appear destined to eclipse Japan's ODA activities in Muslim Asia. China can be easier 
than Japan to work with; it is less nitpicky about transparency, increasingly able to offer huge sums in loans, willing to take greater risks, and equally important, shares with recipients an identity as part of the developing world. Paradoxically, China is still a recipient of ODA from Japan. Japan does enjoy higher favorability rating than China in wide swaths of Asia, but as Feasel's research shows, these attitudes can change based on perceptions in recipient countries.

It was no surprise when in 2015, Prime Minister Abe announced Japan together with ADB would offer $\$ 110$ billion to finance a development assistance initiative called the Partnership for Quality Infrastructure. Adding "quality” to the title is a deliberate linguistic jab to distinguish Japan's capabilities from China's. "Quality," in fact, was mentioned six times in the February 2015 Development Assistance Charter, usually in the form of "quality growth," yet it was mentioned only once among the previous two charters. Since 2015, “quality” has become the self-defining slogan of Japan's development assistance policy. Abe has reiterated the words "quality infrastructure" (shitsu no takai infura) in Asia on multiple occasions, emphasizing something Japan can offer in a leadership role, which (presumably) China cannot. In June 2017, Abe made the contrast clear. As soon as he finished expressing doubts about BRI's economic viability, and the risk for debtor-nations, he stated, "We Japanese are very particular about some aspects of infrastructure. It must be safe and it must be environmentally friendly" (Abe 2017a).

Japan's development assistance has done much for its soft power in Muslim Asia, but the dynamics of the continent are rapidly changing, as are the facets of foreign policy that control Japan's development assistance. The reputation garnered by Japan is a 
foreign policy asset that is not in the possession of the Chinese, not to mention the Americans or Russians. Yet, reputation is fragile, and if Japan makes its development assistance decisions hinging primarily on geopolitical interests, it risks resentment and disillusionment. If it develops its hard power capabilities and is seen in militarized interventions alongside the U.S., decades of hard work in cultivating a positive soft power image can be destroyed in a very short order. 
Table 6.1: Largest Recipients of Total Japanese ODA, 2015 (in million USD)

\begin{tabular}{lc}
\hline 1. India & $\$ 1,538(15.7 \%)$ \\
2. Vietnam & $\$ 1,419(14.4 \%)$ \\
3. Philippines & $\$ 542(5.5 \%)$ \\
4. Indonesia & $\$ 479(4.9 \%)$ \\
5. Bangladesh & $\$ 465(4.7 \%)$ \\
6. Myanmar & $351(3.6 \%)$ \\
7. Iraq & $335(3.4 \%)$ \\
8. Afghanistan & $317(3.2 \%)$ \\
9. Jordan & $254(2.6 \%)$ \\
10. Kenya & $224(2.3 \%)$ \\
TOTAL & $9,820(100 \%)$ \\
\hline
\end{tabular}

Source: Adapted using data from MOFA (2016).

Table 6.2: Largest Recipients of Japanese Bilateral Grant Aid, 2015 (in million USD)

\begin{tabular}{lc}
\hline 1. Afghanistan & $\$ 283(14.4 \%)$ \\
2. Myanmar & $\$ 202(10.3 \%)$ \\
3. South Sudan & $\$ 81(4.1 \%)$ \\
4. Iraq & $\$ 64(3.2 \%)$ \\
5. Palestine & $\$ 59(3.0 \%)$ \\
6. Laos & $\$ 52(2.6 \%)$ \\
7. Cambodia & $\$ 50(2.5 \%)$ \\
8. Philippines & $\$ 46(2.3 \%)$ \\
9. Pakistan & $\$ 45(2.3 \%)$ \\
10. Jordan & $\$ 44(2.2 \%)$ \\
TOTAL & $\$ 1,971(100 \%)$ \\
\hline
\end{tabular}

Source: Adapted using data from MOFA (2016). 
Table 6.3: Japan's ODA Charters Word Frequency (percentage)

\begin{tabular}{|c|c|c|c|}
\hline word & 1992 & 2003 & 2015 \\
\hline $\begin{array}{c}\text { テロ-(tero-) } \\
\text { "terror-" }\end{array}$ & $\begin{array}{c}0 \\
(0.00)\end{array}$ & $\begin{array}{c}5 \\
(0.13)\end{array}$ & $\begin{array}{c}3 \\
(0.04)\end{array}$ \\
\hline $\begin{array}{l}\text { 環境- (kankyō-) } \\
\text { “environment-” }\end{array}$ & $\begin{array}{c}6 \\
(0.34)\end{array}$ & $\begin{array}{c}6 \\
(0.16)\end{array}$ & $\begin{array}{c}18 \\
(0.22)\end{array}$ \\
\hline $\begin{array}{c}\text { 民主- (minshu-) } \\
\text { "democra-" }\end{array}$ & $\begin{array}{c}2 \\
(0.11)\end{array}$ & $\begin{array}{c}5 \\
(0.13)\end{array}$ & $\begin{array}{c}10 \\
(0.12)\end{array}$ \\
\hline $\begin{array}{c}\text { 人間安全保障 } \\
\text { (ningen anzen hoshō) } \\
\text { "human security" }\end{array}$ & $\begin{array}{c}0 \\
(0.00)\end{array}$ & $\begin{array}{c}2 \\
(0.18)\end{array}$ & $\begin{array}{c}4 \\
(0.17)\end{array}$ \\
\hline $\begin{array}{l}\text { 人権 (jinken) } \\
\text { "human rights" }\end{array}$ & $\begin{array}{c}2 \\
(0.11)\end{array}$ & $\begin{array}{c}4 \\
(0.10)\end{array}$ & $\begin{array}{c}8 \\
(0.10)\end{array}$ \\
\hline $\begin{array}{l}\text { 繁栄 (han'ei) } \\
\text { "prosperity” }\end{array}$ & $\begin{array}{c}3 \\
(0.17)\end{array}$ & $\begin{array}{c}3 \\
(0.08)\end{array}$ & $\begin{array}{c}18 \\
(0.22)\end{array}$ \\
\hline $\begin{array}{l}\text { インフラ (infura) } \\
\text { "infrastructure" }\end{array}$ & $\begin{array}{c}3 \\
(0.17)\end{array}$ & $\begin{array}{c}0 \\
(0.00)\end{array}$ & $\begin{array}{c}9 \\
(0.22)\end{array}$ \\
\hline $\begin{array}{c}\text { 平和- (heiwa-) } \\
\text { "peace-" }\end{array}$ & $\begin{array}{c}5 \\
(0.28)\end{array}$ & $\begin{array}{c}11 \\
(0.31)\end{array}$ & $\begin{array}{c}43 \\
(0.54)\end{array}$ \\
\hline $\begin{array}{c}\text { 安定 (antei) } \\
\text { “stable/stability" }\end{array}$ & $\begin{array}{c}2 \\
(0.11)\end{array}$ & $\begin{array}{c}8 \\
(0.21)\end{array}$ & $\begin{array}{c}36 \\
(0.45)\end{array}$ \\
\hline $\begin{array}{l}\text { 法の支配 } \\
\text { (hō no shihai) } \\
\text { "rule of law" }\end{array}$ & $\begin{array}{c}0 \\
(0.00)\end{array}$ & $\begin{array}{c}0 \\
(0.00)\end{array}$ & $\begin{array}{c}9 \\
(0.22)\end{array}$ \\
\hline $\begin{array}{c}\text { 質の高い } \\
\text { (shitsu no takai) } \\
\text { "(high) quality” }\end{array}$ & $\begin{array}{c}0 \\
(0.00)\end{array}$ & $\begin{array}{c}1 \\
(0.05)\end{array}$ & $\begin{array}{c}6 \\
(0.16)\end{array}$ \\
\hline
\end{tabular}




\section{CHAPTER VII}

\section{DEMOCRATIZATION AND HUMAN RIGHTS}

Japan's Arc, as values-based diplomacy, is an overt statement that values are included in its foreign policy thinking. Values, however, are always present in every state's foreign policy, including Japan's. Overt or not, any foreign policy action has meaning, and constitutes an expression of some value to the actor. Japan's version of foreign policy was previously deemed "mercantilist power," and values were known to be seeded mostly by economic interests (Fouse 2007). The Arc opens this up linguistically, and transparently includes values beyond economic interests which may have always been present, but not expressed. What are these values to watch for in Japan's foreign policy with Muslim Asia? How does Japan go about expressing them? How do these values factor into strategy, particularly regarding securitization?

Asō's Arc speech centered around two familiar concepts: democratization and human rights. When Abe regained the prime minister's office in December 2012, he carried out values-based diplomacy centered on these same concepts. These two concepts tend to be at the core of the values-based criticisms Western powers wage against the administrations of certain non-Western states, and thereby make decisions for assistance, partnership, economic sanctions, or even interventions. To champion democratization and human rights is something new for Japan, at least as part of its foreign policymaking. This is not to say Japan cannot make a strong case for democratization and human rights; it is a success story of sorts, in terms of the postwar U.S. forces imposing democratic institutions of governance, a constitution that provides a litany of rights to the citizenry, 
and legal, industrial, and agricultural reforms that provided a nebulous basis for a free market. These were essential in facilitating the postwar miracle.

Contemporary indicators often show Japan as a relatively well functioning democracy with a human rights record that surpasses much of the rest of the world. Indeed, Japan is often the exemplar of a non-Western state embracing a 'universal standard' for democratization and human rights, and achieving success through it. Yet, unlike the West (or Muslim societies), Japan is not a society predicated on universalistic religious truths that lay the foundation to its worldview, nor is there a historical proclivity to proselytizing a beliefs system or way of life. On the contrary, as a religious foundation to Japanese social milieu, Shinto actually teaches relativism of truths based on context in the present, and emphasizes natural uniqueness rather than universality (Yamakage 2006, 40; Kamata 2009, 34). Therefore, Japanese society tends to identify itself by uniqueness far more than commonality with others, be it the West or Asia. This chapter explores how Japan has gone about perpetuating its values of democracy and human rights in Muslim Asia.

In January 2016, Abe expounded on these values at the Shared Values and Democracy in Asia Symposium in Tokyo:

[b]e it lovingkindness, benevolence, fraternity, or harmony, I believe that in Asia, there extends an underground rootstock of thinking that supports democracy and values freedom and human rights. From there, a beautiful and large-bloomed lotus flower is now coming into bloom. Coupled with increasingly flourishing trade and investment, it is bringing peace and prosperity to Asia. If this is not something for us to rejoice about, then I must ask, what on earth is (Abe 2016)? ${ }^{1}$

\footnotetext{
${ }^{1}$ This is the official English translation available from the Office of the Prime Minister. Jihi (慈悲) is translated into "lovingkindness," but is perhaps more appropriately "mercy."
} 
He also used the opportunity to emphasize these shared values specifically with Muslim Asia: "[t]hose of you from Indonesia, Malaysia, or Pakistan will, I believe, say that you find a morality identical to lovingkindness and benevolence within the teachings of Islam as well” (Abe 2016). By mapping out Abe's statement in Figure 7.1, the values-based construction of an Asian geoculture is clear, but how has Japan arrived at promulgating democracy and human rights, and at an understanding that these values are shared with Muslims in Asia?

This chapter proceeds by first considering the historical developments which lay the groundwork for the contemporary conceptualization of democracy and human rights in Japan. It then considers how these ideas have seeped into foreign policy, via the concept of human security. Next, a content analysis is carried out to reveal how political actors are linguistically framing democracy and human rights in Japan's foreign policy today. Lastly, the chapter looks at specific cases of dialogues and humanitarian crises whereby Japan is promulgating democracy and human rights, as it conceptualizes, and fits this into a larger strategy, being mindful of how it relates to securitization.

\section{Development of Democracy and Human Rights in Japan}

As mentioned above, cross-national comparisons tend to show Japan as a robust democracy. Some observers, however, tend to be more skeptical, particularly with regard to the representative political institutions. Hayes calls the Diet "nothing more than a rubber-stamp agency to legitimize decisions made by a self-perpetuating economic and political elite" (2018: 238). Woodall argues "six and a half decades after establishing a parliamentary system in form, Japan has yet to establish parliamentary government in practice" (2014: 221). Bowen makes the case, "[b]y reelecting corrupt politicians and by 
remaining silent when insiders and not the parliament decide who will control the government, Japanese voters are effectively abandoning moral standards (tatamae [sic]) and are yielding to realpolitik (honne)" (2003: 115). Pesek points out that "Japan's government...is one run mostly by nameless, faceless career bureaucrats building their own fiefdoms and power structures" (2014: 165).

These criticisms are aimed at the functionality of the Diet, as a representative institution, but criticisms are much broader. One political party, LDP, has been in power with only two brief interruptions since 1955. In both of these brief interruptions, opposing parties gained power, yet fail to function efficiently because 'the 1955 system' is so deeply institutionalized; the LDP inevitably returns to power. Corruption and bribery scandals are not unusual among the political elites and often (but not always) tolerated by the public. Only certain media outlets monopolize access to political elites via the kisha club system, and tend to be complicit with the political elites in what they report. Laws to prevent conspiring to carry out crimes, including 1996 amendments to the Religious Juridical Persons Law, and the 2017 anti-conspiracy law (kyōbōzai), allow for legal surveillance in certain cases, and possibly violate constitutional rights to freedom of religion and free assembly. Various forms of discrimination against ethnic minorities and foreigners persist. Criminal suspects can be detained for weeks without bail or a lawyer present during interrogations - which almost always produces a confession to a crime.

These are all credible critiques of Japan's democracy and human rights, but provide a selective understanding. Interestingly, survey data shows Japanese believe they have more influence on their government than most Westerners. A 1999 survey asked whether respondents agreed with the statement: "People like me don't have any say about 
what the government does." A surprising 54 percent of Japanese "strongly disagreed" with the statement (ISSP 1999, v47). Among Americans, however, it was nine percent; among Brits, two percent (ISSP 1999, v47). Nearly two decades later, a 2017 Pew survey asks: "How satisfied are you with the way democracy is working in [your] country?" To this, 23 percent of Americans and 16 percent of Brits were "not at all satisfied," but only nine percent of Japanese responded this way (Wike, et al. 2017, 37). In the same survey, Japanese expressed more trust in their government than Americans, Brits, Italians, French, and other Western proponents of democratic values (Wike, et al. 2017, 36). ${ }^{2}$

In national politics, civil society appears muted in Japan in comparison to other democracies, but, in fact, at the local level it is more dynamic. Haddad argues that the exclusivity of national politics has actually "translated into high participation rates in civic organizations" (2012: 192). Moreover, "Japanese explain their participation as performing a civic duty, a way of fulfilling a community responsibility, rather than as an individual choice about whether to participate" (2012: 192-93). Critics who claim "[a] spiritual commitment [to democracy] is lacking" are not looking in the right places (Hayes 2018, 238). Kuroda contends that "Japanese democracy seems to be void of individualism, for consensus making is paramount, not majority rule" (2005: 204). Therefore, the outcome of decision-making is more likely to represent a compromise of all voices, rather than just the view of the majority. This applies to the view of political elites as well as the society, writ large.

\footnotetext{
${ }^{2}$ Japanese indicated less trust in their government, however, than Germans and Canadians (Wike, et al. 2017, 36).
} 
It is perhaps easy to overlook the things which Japan's approach to democracy and human rights does get right: industrial quality is among the highest in world, crime rates are among the lowest, the wealth gap is among the narrowest, average life expectancy is among the longest, student attainments in math and sciences are among the highest, universal literacy, a highly-regarded healthcare system, a strong and improving environmental record with a broad societal consciousness toward recycling and conservation, and despite the occasional alarmism, an enduring commitment to global peace that surpasses any other great power today. These are characteristics of democracy and human rights most Western states cannot claim, and characteristics many envy. To what extent these characteristics are concomitant with democracy would depend on the conceptualization of the elusive term. They are certainly characteristics, however, of a state meeting basic human rights, and thus, shape Japan's conceptualization of human rights, which it endorses internationally.

\section{Modern Democracy}

Democracy, as the term is understood today, was introduced to Japan no earlier than the mid-nineteenth century. The contemporary Japanese term for 'democracy,' minshu (民主), has origins in Chinese classical texts that literally means a ruler (nushi) (主) over the people (tami) (民), but was appropriated by Japanese translators to imply a contrary meaning - something to translate the English 'democracy,' French 'démocratie,' and the list of other European cognates they were rapidly encountering at the time (Chen 2011, 10). The earliest known use of the term 'minshu' as an ideological movement was first applied in Japanese in 1888, in the expression "minshu no seishin" (democratic spirit), after popular-elected assemblies introduced in the prefectures and swelling rural 
unrest incited greater public representation (Chen 2011, 28). From there, the term 'minshu-shugi,' or 'democracy (as ideology)' was formed.

As the Western notion of the concept was more widely learned during the Meiji Restoration, minshu generally carried a negative connotation, and was considered unsuitable for Japan. Meiji reformers studied and applied many Western concepts as a means to strengthen the legitimacy of the state, but in what could be called "permissive effects," inadvertently introduced institutions that formed the impetuses to Japan's contemporary notions of democracy and human rights (Tannenwald 1999, 437). Early twentieth century political scientist Yoshino Sakuzō grappled with this very question of reconciling the Western concepts as they were applied to Japan's state and society. Yoshino made the argument that Japanese society was compatible with the English term 'democracy,' but not with the Japanese notion of minshu-shugi. To Yoshino, mishu-shugi implied, "sovereignty resides in the people due to legal principle," and is thus, incompatible with the reality of Japanese society (Chen 2011, 28). Yoshino resolves this issue by introducing minpon-shugi (民本主義), ${ }^{3}$ which implies "the base objective to a sovereign's actions must reside in the people, politically" (Chen 2011, 28). Yoshino argues, "minpon-shugi is a government for the 'gains and happiness of all peoples,' and policymaking is established on 'general will of the people"” (Chen 2011, 28). Yoshino's term never gained currency as a conventional term, but it serves as a useful academic distinction that provides insight into how democracy could reconcile with an existing socio-cultural milieu, and the distinction preempts language that would be seen later in

\footnotetext{
${ }^{3}$ Minpon is a compound of tami, or 'people,' and moto, or 'base,' and has been translated into the cumbersome 'people-based-ism.'
} 
Japan's postwar constitution, as well as its conceptualization of human security, democracy, and human rights today.

\section{Postwar Democracy}

The postwar U.S. occupation of Japan is a critical juncture in Japan's conceptualization of democracy and human rights, but also of Self. American democracy was imposed on Japan in the most authoritarian of ways, yet it is arguably the most successful imposition of democracy in world history. In fact, the case of American occupation and democratization of Japan from 1945 to 1952 was an oft-cited exemplar for supporters of U.S.-led democratization in both Afghanistan and Iraq in the early 2000s. After these efforts in the early twenty-first century, many questioned why it did not work in these cases, and yet the question in reverse is just as pertinent: Why did it work in Japan?

Among a multitude of sweeping democratization reforms, U.S. General Douglas MacArthur commissioned the drafting of a new constitution for Japan. In May 1947, a final document was completed after several revisions by the selected Japanese drafters and American advisors. While the responsible parties for the specific contents of the document remain vague, the dominant narrative today is that Japanese politicians wrote the constitution with guidance by American advisors. The truth is murky, but for whatever role American advisors had in the document, the Constitution has become accepted and embraced as a normative base for Japan in the twenty-first century. 
Today, it is considered the 'Peace Constitution' because of the renowned Article IX, which renounces the right to war. ${ }^{4}$ The constitution was written in a remarkable manner for its time regarding both democracy and human rights. MacArthur is known to have remarked that the document was "the most liberal constitution in history" (1964: 301). Pyle notes, "[i]t guaranteed many more human rights (including gender equality) than the U.S. constitution," and it commanded a "redesign of the education system to teach liberal values of democracy, individualism, internationalism, and peace" (2018: 73). The preface states, "[w]e recognize that all peoples of the world have the right to live in peace, free from fear and want" (Japan Const.). It is a remarkable statement expressing a Kantian world order. It builds on this view, adding, "laws of political morality are universal" (Japan Const. Preface). A following set of articles preempt the concept of human security, a neologism not yet coined, and yet reverberate Yoshino's concept of minpon-shugi. Beyond basic democratic rights such as freedoms of speech, movement, assembly, 'unconventional' rights are also asserted, such as the right to "maintain the minimum standards of wholesome and cultured living" (art. XXV, § 1), the right to "equal education" (art. XXVI), and a declaration that "the State shall use its endeavors for the promotion and extension of social welfare and security, and of public health" (art. $\mathrm{XXV}, \S 2)$.

The American imposition of liberal democracy worked in Japan for five reasons. First, it was in the context of the Cold War. The Japanese viewed the Soviet Union as a threat, and this was exacerbated when Soviet-ally North Korea invaded South Korea in

\footnotetext{
${ }^{4}$ This is discussed further in the following chapter.
} 
1950. Secondly, Japan was decimated from war, much of the population was still overseas in former colonies, and a significant portion of the young male population had been erased from the workforce. American aid came with strings attached in terms of democratization, but it was little to ask of a country where the economy, infrastructure, and society were in shambles. Thirdly, while brief, Japan had experience with democracy in the 1920s, known at Taisho Democracy. The notion was not entirely unfamiliar to them. Fourth, Japan sensed nothing but animosity from its neighboring states in East Asia - the experience of Japanese invasion and occupation was fresh in their minds. From Japan's perspective, oddly enough there seemed to be only one friendly state particularly in their region, but by extension in the world - the U.S.

Lastly, Japanese acquiesced, as a defeated nation. As recognized by Ruth Benedict in The Chrysanthemum and the Sword, it is the quintessential shame culture. In the shame of defeat, there is no escaping this existence from an international society. For an individual, taking responsibility for the shame of defeat was done, at least, by resignation of post, and, at most, an honor suicide, and, indeed, several Japanese military and political elites did one or the other to accept responsibility for the war defeat. The state and society, however, did not have that option to escape the shame of defeat. Therefore, as a defeated nation, its only option was to acquiesce firstly to its victor, but secondly to the international society in which it remains. Thus, the closest thing to maintaining dignity was to follow what the victor demands. All of these conditions make nation building a very different enterprise in Japan of the 1940s than Afghanistan or Iraq of the early twenty-first century. 
To many Japanese the democratic institutions, including the new constitution, were misguided and unsuitable at the time, but Japanese acquiesced as it was something to be endured (gaman) as a conquered nation. After the occupation ended in 1952, the democratic institutions left served as a substratum for societal construction of a new Japan, by incorporating values and norms from these institutions, regardless of how they entered the state and societal structure. Yet, at the same time, in order for democracy to survive, it needed to be shaped and cultivated into the new state identity.

The one policymaker who stands out as successfully carrying out that vision happens to also be Asō Tarō's grandfather, Yoshida Shigeru. Yoshida's method of statecraft, deemed the 'Yoshida Doctrine,' would shape Japan's norms and values in both domestic and foreign policy for decades to come. The Yoshida Doctrine had two key principles: firstly, rely on the U.S. for national security so that Japan could retain adherence to Article IX in the Constitution; secondly, without military capabilities, Japan's foreign policy must focus squarely on economic interests to recapture a major power status in global politics. Therefore, bandwagoning security with the U.S. was a means to retain and ensconce an Article IX-based non-militarization norm, and it was through wholehearted focus on geo-economics, that Japan's geopolitical stature could be regained.

\section{Human Security, as a Foreign Policy Value}

Both prewar and postwar norms and values constructed intentionally and inadvertently, by both Japanese and Americans, formed contemporary notions of democracy and human rights in Japan. Reflecting on its postwar economic miracle, the values emanating from its Peace Constitution and maturing postwar identity, and the Yoshida Doctrine, in the 
last two decades of the twentieth century Japan began actively advocating for a reframing of security at the international level, beyond national security, against traditional foreign military threats. Against the backdrop of declining American hegemony in Asia and attainment of higher national affluence in Japan, re-conceptualizations of security started with the comprehensive security policy in 1980. In the milieu of the post-Cold War, Japan began promoting its conceptualization of human security internationally in the 1990s.

Japan's 2015 Development Cooperation Charter defines human security as "a concept that pursues the right of individuals to live happily and in dignity, free from fear and want, through their protection and empowerment" (MOFA 2015b). The expression "free from fear and want" is directly replicated from the preface of the Peace Constitution, and indirectly relates to the concept of minpon-shugi that preceded it. They are also two of the Four Freedoms articulated by U.S. President Franklin Roosevelt in January 1941. In 1994, the UN Development Program announced its adherence to the concept of human security, in an attempt to shift the perpetual referent object from the state to the people. "This implied a radical widening of the types of threats and sectors to which security was applicable to food, health, the environment, population growth, disparities in economic opportunities, migration, drug trafficking and terrorism" (Buzan and Hansen 2009, 203). Japanese Prime Minister Murayama Tomiichi was one of the first world leaders to endorse the concept for the UN (Edström 2011, 9). This UN Development Program application of human security would not have been possible without the simultaneous promotion of such a concept by Japan, Norway, and Canada all three states notable for affluency and economic power, but constrained military power. 
Edström argues that "Japan was searching for an international role commensurate with its considerable economic power and the Japanese government had begun to take measures to strengthen Japan’s “international contribution”' (2011: 9).

Prime Minister Obuchi Keizō made human security a central theme of his foreign policy in 1998, and introduced the Trust Fund for Human Security for the UN, with a donation by the Japanese government of 500 million yen (Edström 2011, 12). In 2000, Japanese diplomat to the UN, Takasu Yukio explained Tokyo's approach:

There are two basic aspects to human security - freedom from fear and freedom from want. Some countries seem to focus solely on the first aspect. For these countries, human security provides a conceptual basis for taking actions to preserve the life and dignity of individuals in conflict situations...In Japan's view, however, human security is a much broader concept. We believe that freedom from want is no less critical than freedom from fear. So long as its objectives are to ensure the survival and dignity of individuals as human beings, it is necessary to go beyond thinking of human security solely in terms of protecting human life in conflict situations (Takasu 2000).

The mention of "objectives...to ensure the survival and dignity of individuals as human beings" relates to the 'people-base' in minpon-shugi. Additionally, the expression, "freedom from fear and freedom from want" is applied yet again, but this time in the context of defining a new, international concept, thus promulgating domestic democratic values to the international system. Takasu added, "I believe that Japan's experience since the end of the Second World War in promoting prosperity and the well-being of its people through economic and social development makes it particularly well-prepared to advocate such a broad concept of human security" (Takasu 2000). Thus, the Japanese conceptualization of human security directly ties to the postwar experience of rapid prosperity and the values expressed in the Peace Constitution. 
In December 2001, three months after the 9/11 attacks on the U.S., Prime

Minister Koizumi Junichiro shifted the language on human security:

To eradicate terrorism, it is necessary to tackle not only terrorism itself but also other diverse threats to individuals. This means that we have to build and sustain a society where individual human beings can fully realize their possibilities. This is what "human security" aims at, and this is what Japan's foreign policy has attached importance (Koizumi 2001).

In the twenty-first century, human security was applied to address terrorism in addition to the other issues already stated. The language Koizumi used addressed human security as an effective securitizing sector against a terrorism threat; the strategy is the same, yet the challenge (threat) has changed.

By 2004, however, Japanese diplomats began relegating references to human security exclusively as a part of ODA policy, rather than the broader foreign policy. In the 2003 ODA charter, human security debuted as a "perspective" for ODA objectives, but in the 2015 version, this was enhanced to "promoting human security," stating that human security "is the guiding principle that lies at the foundation of Japan's development cooperation" (MOFA 2015b). It elaborates, Japan will "focus its development cooperation on individuals... and provide cooperation for their protection and empowerment so as to realize human security" (MOFA 2015b). Importantly, it adds, "Japan will make efforts so that this basic policy will be understood and accepted widely among its partner countries, thereby mainstreaming the concept even further in the international community" (MOFA 2015c).

Making the concept "understood" and "accepted" in order to "mainstream" it is a clear expression of proselytizing values via diplomacy, but left ambiguous is how Japan "will make efforts" to do so. In this way, the standards for human security, determined by 
Japan, are either objectives of ODA policy, or a checklist recipient states must follow before obtaining permission to receive ODA (Edström 2011, 56-57). The relegation to ODA reflects a downgrading of the prominence of the concept to Tokyo's foreign policy, but keenly so in strategy. Japanese diplomats were no longer attempting to champion the concept in the UN. Edström suggests this is likely a result of Japan's failed attempt to garner a permanent seat in the Security Council in 2005 (2011: 52). It is also possible Japan chose to end championing human security in the UN after 9/11 and subsequent changes in international politics stole the focus from such initiatives. Nonetheless, the values expressed in Japan's foreign policy would soon widen.

\section{Contemporary Values Conceptualizations in Foreign Policy}

A good indicator of how democracy and human rights are conceptualized today in Japan is the string of words frequently uttered together with these terms by political elites. Moreover, considering the audiences where 'democracy' and 'human rights' are discussed (and not discussed) in dialogues, speeches, bulletins, et cetera, indicates where these values are most important for Japan. In his 2006 speech introducing the Arc of Freedom and Prosperity as a new pillar to Japan's foreign policy based on values, Asō framed democracy and human rights together with "freedom," rule of law," and "the market economy" as "universal values" (Asō 2006b). These words consistently appear together as a fuzzy-set string in statements by Asō during his brief tenures as foreign minister and prime minister, but also by Abe and other political elites commenting on foreign policy.

When the 'old guard' of experienced LDP former prime ministers, Abe and Asō, returned to power in December 2012, the language from the 2006 Arc speech also 
reappeared with greater consistency. By analyzing the speeches, responses in interviews and press conferences, and newspaper columns provided by the Prime Minister and two foreign ministers since December 2012, notable trends are evident. Unlike the brief tenures of previous prime ministers and foreign ministers between 2006 and 2014, Abe's current tenure has the longevity to create enough momentum in foreign policy so that even if he or Deputy Prime Minister Asō were to leave office in the near future, the their policies are firmly set in place, particularly among the bureaucracy which likely shares responsibility for formulating and carrying out the policies just as much as Abe and Asō themselves (Pyle 2018, 90).

A notable change between Asō circa 2006 and Abe circa 2013 is the use of 'universal values' (fuhenteki kachi) to describe the string. Abe and other political elites use this term rather freely while speaking in Japan, to both Japanese and international audiences, yet if overseas in Asia, including Muslim Asia, they replace it more often than not with "basic/fundamental values" (kihonteki kachi). ${ }^{5}$ The same fuzzy set string of terms are used, 'democracy,' 'freedom,' 'human rights,' and 'rule of law' (see Tables 7.1, 7.2, and 7.3), yet Japanese political elites are choosing to bind these together as 'basic,' or 'fundamental values' in Muslim Asia and 'universal values' in Japan. The only identified cases where 'universal values' was used in Muslim Asia to describe these was a speech given by Abe in 2013 and a newspaper interview with Abe in 2017, both in Indonesia. Moreover, while 'basic values' is used to describe these terms multiple times in other locations, it only occurs in Kyrgyzstan, Malaysia, and Indonesia (again) - three

\footnotetext{
${ }^{5}$ Both 'basic' and 'fundamental' are used interchangeably in official English translations of kihonteki (基本 的).
} 
of the most democratic states in Muslim Asia. In the collection of statements in 16 other Muslim Asian countries, 'basic/fundamental values' was either never mentioned or used in an irrelevant context. Thus, the less democratic the state in Muslim Asia, the less likely 'basic/fundamental values' was uttered by Japanese political leaders.

The remarkable consistency between Asō 2006 and Abe 2013 is the string of four terms: democracy, human rights, freedom, and rule of law, as a package, although none of the four terms, on its own, is a necessary condition. Notably, 'market economy' has become omitted more often than not from the fuzzy set string of descriptors of universal values. Economic aspects continue to be discussed in detail, but 'market economy' appears consciously removed from the list of 'universal values.' Aspects of market economy still tend to appear elsewhere in their statements, but the term, itself, has markedly disappeared from utterances of the string of terms while in Muslim Asia since 2013. These terms associated with democracy and human rights are worthy of discussion, as they are obviously the values intended in the naming, values-based diplomacy.

First, and just as pervasive as 'democracy' and 'human rights' is 'freedom.' Official translations by MOFA and the Prime Minister's office apply "freedom" to mean $j i y \bar{u}$ (自由), but like most languages, Japanese does not have a distinction between "freedom" and "liberty." Changing the text to "liberty" would not necessarily be considered problematic when presented as a "universal value," but framing the term as qualifier of democracy would then make it "liberal," as in "liberal democracy." Together with rule of law, what is striking about these terms is how they form key components of how most would define Western liberal democracy. Francis Fukuyama defines liberal democracy as such: 
The liberal part, which is a rule of law, meaning generally accepted rules that put clear limits on the way that the state can exercise power. Then the second is democracy [italics added], like elections to guarantee that the state represents the interest of as much of the population as possible and not just the elites that are running the state (2017).

Japan's values-based diplomacy is predicated on values widely associated with a model of governance that originates in the West, and currently faces its most immense image challenge in the last half century. Yet, is the propagator of liberal democracy in Asia Japan?

While neither Abe, nor Asō, or any other Japanese political elite has uttered the words jiyu-minshu-shugi ('liberal democracy') in that order, as a "universal value," the terms are consistently used together in the fuzzy set to describe universal values or basic/fundamental values, and the listener can easily assume its implication. In several instances including the Arc speech in 2006, both Asō and Abe join "jiy $\bar{u}$ ” to "minshushugi" with an 'and' conjunction, "liberty and democracy," among other "universal values." In a press conference in Singapore in 2013, an interview with the Star newspaper in Malaysia in 2015, at the Asian Values and Democracy Symposium in 2016, and in Kompas newspaper in Indonesia, Abe delineates the two multiple times with a comma: "jiyu, minshu-shugi," which could just as easily be interpreted "liberal democracy" just as well as "liberty [comma] democracy," and again, as "universal values." Notions of liberal democracy, as opposed to democracy itself, are presumed as a Western model, and are questioned globally today not as a solution to problems, but the problem itself. Yet, relying on its historical experiences, Japan stays close to the conventional conceptualization of liberal democracy in this time. In February 2018, while in Munich, Foreign Minister Kōno Tarō stated: 
I believe Japan and Europe share the view that, to date, the liberal international order has been an important part of the development of the postwar global economy. In particular, until now, there has been the opinion that economic growth leads to democratization, but considering recent models of economic growth, especially economic growth due to state capitalism, it has not always led to democratization. Even so, I like knowing that we share the view with Europe that free and open capitalism is important, and it leads to democratization, the rule of law, and basic human rights (Kōno 2018).

Second, 'rule of law' is the enforcing mechanism of the equality principle in liberalism, but just how universal is rule of law? How compatible is it with a Confucianist society where the leader's behavior is predicated on principles of benevolence rather than constraints of law? The values system of a Confucian society conduces it to become a functional system as it moves away from rule of law (Qin 2008, 74). Rather than rule of law, the ideal Confucianist society is rule of man - a benevolent man. "Under the rule of man, law is just as the sword in man's hand, whereas, under the rule of law, law is the sword suspending over man's head" (Qin 2008, 73). To complete the analogy, from the Islamic tradition, it is 'rule of God,' or 'Divine Law,' as it relates to shari' $a$ and more specifically, fiqh, or jurisprudence. Nasr has likened shari' $a$ to a firmly rooted tree with branches: "[t]he Shari'ah has developed in many different cultural and political climates over the centuries. It has harbored many differences of interpretation" (2002: 124). Like the Western legalistic rule of law and Confucian rule of man, the notion leaves much for interpretation, and is equally carried out in a multiplicity of ways in practice. Unlike the Western rule of law, the Confucian and Islamic systems share a predication on moralistic principles for social order, including the behavior of the political leadership.

Simply because rule of law has a Western legalistic origin, however, is not to suggest it is neither compatible nor desired by Japanese or Muslims. To say so is to 
support claims of a 'Clash of Civilizations' based on primordial value systems. Learning takes place; sampling takes place. Many Japanese and Muslims rely on rule of law, and have positive views of it. In the case here, however, the true meaning of the repeated utterances does not indicate an advancement of rule of law as it is a priority for Japanese political elites speaking in Muslim Asia; at least not the conventional notion of rule of law.

The very mention of rule of law by Japanese political elites, however, appears to have a specific intention, and one that applies to international rather than domestic law. That threat is China, and its active expansion into the South China Sea potentially disrupting the flow of energy resources from the Persian Gulf to Japan. Occasionally, this implication is clearer when political elites also speak of the UN Convention of the Law of the Sea (UNCLOS), stability, order, a 'Free and Open Indo-Pacific,' and emphasizing the use of peaceful means to settle disputes. This assumption is evident in the context when 'rule of law' is uttered outside the typical fuzzy set string of terms - it is almost always in reference to international maritime law, if not to the South China Sea, specifically. An example to illustrate this argument is an exchange between a reporter and Kōno at a press conference in February 2018 in Munich. The reporter asked, "Did you reach any conclusions [at this Munich Security Conference] as a result of the discussion about China?" To this, Kōno responded, "I think that China achieving sound economic development based on the rule of law within the international order [italics added] is extremely beneficial for the world economy" (Kōno 2018).

Third, market economy has been broken down into its components and is not uttered in the string together with the others in Muslim Asia. It is, however, occasionally 
still uttered together in this string of terms multiple times in the annual Diplomatic Bluebooks (see Table 7.4). Instead, frequently uttered words in Muslim Asia are “development," "growth," "prosperity," "investments," and "infrastructure.” In fact, a comprehensive sweep of statements made in Muslim Asia by Japanese policymakers between 2013 and 2018 shows that these words were uttered considerably more than “democracy" or "human rights" (see Table 7.5). The economic language harkens back to the Yoshida Doctrine, as it was Japan's postwar experience that a foreign policy leading with market-based economic interests leads to peace and stability - other terms occasionally associated with these concepts.

The fuzzy set string of terms, leading with democracy or human rights, plus any combination of rule of law, freedom/liberty, or market economy appears in the 2015 , 2016, and 2017 Diplomatic Bluebooks over 20 times each (see Table 7.4). The opening sentence in the 2017 edition states:

In order for Japan to ensure its national interests in the political, security, and economic domain, and to continue to maintain and develop an international order desirable for Japan based on universal values such as freedom, democracy, rule of law, and human rights, it is essential to conduct strategic diplomacy, while rationally grasping changes in the international situation and responding to those changes (MOFA 2017c, 1).

The conceptualization of democracy and human rights is couched in this series of terms, and the consistency indicates it is deliberate. The political elites reinforce the conceptualization of democracy and human rights through repetition.

None of these concepts would necessarily indicate views of democracy and human rights differing from the West, although a fourth concept which is occasionally uttered with the aforementioned is not as likely to come from a Western political elite: 
'harmony' (wa). References to 'harmony' in society are very deeply seeded in Japan's conceptualization of Self, and therefore, it is no surprise it is incorporated into their unique conceptualization of democracy. Placing harmony at the center of social order goes back to the 17-Article Constitution written in the early seventh century by Prince Shōtoku (coincidently, less than two decades prior to the Prophet Muhammad writing the Constitution of Medina). Often considered one of the first 'constitutions' in history, the 17-article document standardizes Buddhist and Confucian precepts in Japanese society, and thereby serves as a very early set of values and moral injunctions to unify the state. What is most remarkable about Prince Shōtoku's document is how it emphasizes harmony as the bedrock to Japan's values system, and this point was actually made by Asō in his Arc speech: "[t]here is some lively discussion about what we should consider the proper start line [of Japanese democracy] to be, such as the Seventeen Article Constitution that existed some 1400 years ago" (Asō 2006b). Therefore, harmony is the base of values in 'values-based diplomacy.'

The document synergizes religious and philosophical teachings, but most significantly, it places harmony $(w a)$ at the center of society. Article I says "[h]armony should be valued and quarrels should be avoided." Article XV states "if a man is influenced by private motives, he will be resentful, and if he is influenced by resentment he will fail to act harmoniously with others. If he fails to act harmoniously with others, the public interest will suffer." A century and a half later, Japanese scribes began applying the character for 'harmony' (和), to serve as shorthand reference to Japan, itself - a practice that continues today. Over a millennium before democracy as a concept was ever introduced to Japan, harmony was entrenched at the core center of social order that 
would eventually mesh with, and contort, the imported modern concept of democracy into the Japanese variant known today.

While harmony is used to describe, in certain circumstances, the Japanese brand of democracy, it is also used by Japan's political elites to emphasize a broader Asian brand of democracy as well. This is significant in that Japanese view harmony as a key characteristic of Self, yet at the same time, they present it as a value conducive to a broader Asian society, and contrasting to Western societies. Thus, Japan is the model for the value of social harmony, or one could say, "Japan is wa"; it is attainable in Asia, but not particularly elsewhere. In any case, it also clashes with the references made to "universal values," which may account for the use of "basic/fundamental values" instead.

Japanese international relations scholar Takahashi Kazuo aptly argues that framing Japan's values-based diplomacy on "universal” values is ill-advised: "If Japan parrots the same assertions as the U.S., no one will take interest" (2013: 4). Rather than "universal values," Takahashi recommends adding "Japanese flavor" to the values (2013: 4). This "Japanese flavor" can manifest in strategy in two ways: first, "have an example which others can emulate"; second, "pursue 'harmony' (wa)" (Takahashi 2013, 7). He adds, "wa is the most comprehended key word across the world in the twenty-first century," and Japan should be at the center of this in its values-based diplomacy (Takahashi 2013,7). One could easily find cases to counter this assertion with a cursory scan of daily news headlines in Japan, and point out the 'unharmonious' that exists in Japanese society, politics, and business on a daily basis, but it would be somewhat regardless of the point. Japan is just as harmonious as the U.S. is free; wa is to Japan what liberté, égalité, fraternité are to France. What does harmony entail, as a 
promulgated value? How do you implement it? Though challenging to conceptualize, but in fact, it is no more nebulous of a concept than democracy, itself. The reality of the concept within the state and society, while significant, plays a much smaller role than the constructed image projected internationally. To many in Muslim Asia, attaining societal harmony would penetrate nearer to the core of real security far more than democracy, liberal democracy, rule of law, or any of these other values. In the milieu of the early twenty-first century, with rising nationalism, populism, and narratives on the clash of civilizations, it is indeed a very attractive notion.

Japan, Muslim Asia, and the Value of Harmony

Advocacy groups for democracy and human rights frequently rank states in Muslim Asia among the lowest levels in the world. While comprehensive, these rankings undoubtedly overlook the qualitative variations within each state, and may contain some biases, but they do provide some degree of understanding of the dearth of democracy and human values in wide swaths of Muslim Asia. In general, democracy and human rights indexes show higher levels in Muslim Southeast Asia (6.47), ${ }^{6}$ while the worst performing region is Post-Soviet Asia (2.74). Using the Democracy Index for 2017, the 27 Muslimmajority states in Asia average a score of 3.48 of 10 (EIU 2018, 5-9). ${ }^{7}$ There are large variations within Muslim Asia, yet the average is lower than any region of the world specific by EIU, including Middle East and North Africa (3.54), and Sub-Saharan Africa (4.35) (EIU 2018, 16-17).

\footnotetext{
${ }^{6}$ Includes only Indonesia (6.39) and Malaysia (6.54); Brunei is not included in the survey.

${ }^{7}$ This is figured by averaging state-level data across Muslim Asia from EIU.
} 
Despite the outcomes of these comparative indexes, it is not to indicate that political Islam is incommensurable with democracy. Even Huntington points out this lack of correlation: "Islamic doctrine...contains elements that may be both congenial and uncongenial to democracy" (1991: 307). Kubicek suggests that like all religions, Islam is “"multivocal,' with concepts that could be both harmful and beneficial to democracy" (2015: 8). Nasr aptly points out the vagueness of the concept, itself:

If democracy is understood as the rule of the will of the people, then there were mechanisms in traditional Islamic society where the will of the people was reflected to the ruling class, including the caliph or sultan, and it definitely played a role in those governments that were successful and that endured. If it means the particular institutions developed during the past few centuries in the West, then there is no parallel for them in premodern Islamic history, no more than there is for them in premodern Japan, China, or India (2002: 150).

Across Asia, the relationship between Islamism and democracy shows little correlation. Muslim-majority secular states tend to lack democratic institutions just as much, if not more so, than Islamic states. Malaysia is often ranked among the most democratic in Muslim Asia, yet Islam is the official religion and multiple Sunni sultans reign. Meanwhile, some of the least democratic states in Muslim Asia are conspicuously under the authority of secular administrations, such as Assad's Syria, Azerbaijan, and the Central Asian republics. Moreover, two of the highest ranked Asian states in democratic institutions, Israel (7.79) and Sri Lanka (6.48), are known to have ongoing discrimination issues against Muslim-minority peoples. Additionally, just as Myanmar has made great strides toward democratization in recent years, the military carries out attacks on the Rohingya Muslim population. These cases certainly complicate the case that democratization would enhance the lives of Muslims in Asia. 
Yet, Japan views its historical experiences as evidence that democratization works. Muslim societies grapple with democracy as part of the modernization package, and this is the same process Japan went through in relation to its religious and philosophical traditions in the nineteenth century, and then in the postwar era. Therefore, it is intuitive of Japanese to expect Muslim societies to progress through democratization in a manner similar to what they experienced, and similar to Huntington's "waves" of democratization based on empirical experiences (1991: 315).

What does this mean for Japan? How does Japan promote democratization and human rights in Muslim Asia? If democratization and human rights are the key values in the values-based foreign policy, how are these values broached? If there is anything Japan has been clear about, it does not want to ask hard questions on democratization and human rights, as the West does. In 1991, MOFA issued the following statement on how aid is handled regarding democratization and human rights:

Japan's approach differs considerably from that of the United States, which regards freedom and democracy as universal values and has made the promotion of these ideas a basic component of its aid activities. There is also a sharp contrast between Japan's position and the emphasis that France places on the promotion of the French language and culture through its aid. As much as possible, Japan strives to avoid the imposition of its own political values or attitudes toward economic development on its aid activities. Instead it has sought to discover, through a process of dialogue based on requests from recipient countries, the best approach to development for each individual country (19).

Japan has clearly shifted to where it now shares the American view that freedom and democracy are universal values, yet it still differs on the strategy of imposition of values, and points out uniqueness ("best approach... for each individual country"). In 2015, Abe reiterated this sentiment: "Japanese do not impose ourselves on others. We take a longterm view, cultivating firm roots in a country. We think together, and more forward 
together, with the local people. This is how Japan operates" (Abe 2015e). If you do not "impose" values, yet values are overtly considerations of your foreign policy, how are they operationalized? Why express them, yet of course, not impose them? Where and when are they expressed, and where and when are they not expressed? The answers to these questions reveal how and when Islam is being securitized.

What language expresses values, and induces or, in Joseph Nye's language, “coopts" these values (2004: 5)? It seems nearly impossible to have a values-based diplomacy, yet not seek to impose them. How to coopt, without imposing? ${ }^{8}$ Suggesting? Modeling? This is illustrated in a key policy concept uttered by Japanese political elites while visiting the Middle East. In January 2015, Abe introduced a concept of "the best way is to go in the middle," while on a visit in Egypt. Foreign Affairs Minister Kishida Fumio reiterated this concept a month later, after the beheading of two Japanese nationals by ISIS militants. Abe has, himself, indicated that he consistently reiterates this concept "at every opportunity" he has to meet with leaders of Muslim countries (Abe 2017b). In 2015, 2016, and 2017, he made it the cornerstone of his Iftar banquet addresses in Tokyo for the Islamic Diplomatic Corps of Japan (Abe 2017b). It has been echoed in MOFA literature and by ambassadors abroad. In June 2015, he linked the language together with 'harmony': "[t]his spirit of Islam, which avoids extreme positions and aims for harmony with those with different views, resonates with the Japanese spirit of aiming for coexistence with others through the spirit of ' $w a$ ' or harmony" (Abe 2015c). The

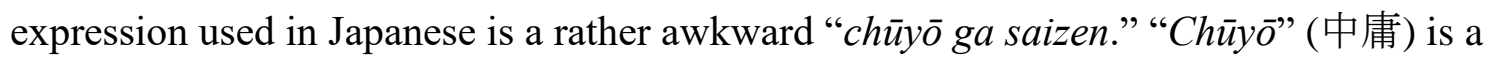

\footnotetext{
${ }^{8}$ Perhaps the U.S. Lend-Lease aid to the Soviet Union during World War II could be considered a case of coopting without imposing.
} 
term drawn from the doctrine of moderation from Confucianism. An emphasis on 'middle' also emphasizes the region as the geographical tri-continental crossroads, as “chūyo" is not dissimilar from “chūt $\bar{o} ”$ (中東), 'Middle East,' and “chüd $\bar{o} ”$ (中道), 'middle road.'

There is a deliberate intention to focus on the middle for two reasons, both of which relate to securitization. Firstly, the idea to promote moderation, and to 'remind' Muslims of this important tradition in their religion is a strategy to root out extremism that is straightforward from this message. This reminder is Abe acting as the securitizing actor. Secondly, as the securitizing actor and partner to the Muslim world, this is the construction of Japan as a unique power - unique in how it operates in comparison to the West, Russia, and China. It is, in essence, Japan 'testing' its values-based diplomacy. Yet, while slogans indicate meanings, how can it translate into outcomes? Does Japan even wield enough power to achieve its outcomes? This question was addressed in December 2017 by Kōno, while speaking in Bahrain:

Some of you may wonder..."Can Japan actually make any contribution in this complicated Middle East?" As the Foreign Minister of Japan, I would proudly like to respond to such questions, with "There are things only Japan can do." Japan is unique because we have remained neutral religiously and ethnically, and we have not left any negative footprint historically in the Middle East. Japan has always remained as a peaceful nation for over 70 years after World War II, continually practicing peace diplomacy with so-called soft power, without exercising coercion or force. It is my belief that Japan can make further contributions to stability in the Middle East in a way that only Japan can do (Kōno 2017).

Japanese Islamic studies scholar Miyata Osamu writes in his 2017 work, Islam's Only

\section{Hope: Japan:}

President Trump is calling to "Make America Great Again," and President Putin is aiming for a "Revival of a Strong Russia." In Europe, there is an appeal 
towards nationalism, as far-right political parties that advocate for EU secessionism and expulsion of immigrants are on the rise (2017: 246-47).

Yet, he offers that while the world's great powers are pursuing strategies to build "strong nations," in contrast, "Japan can lead the world by building a "wise nation"” (Miyata 2017, 248). The term 'wise nation' (kashikoi kuni) is referencing an idea proffered by the late author Nada Inada, who argued that in the twenty-first century, it is not a 'strong nation' that societies desire, but a 'wise nation' (Miyata 2017, 246). Is this - a wise nation - what Japan can promulgate in Muslim Asia? Moreover, the strategy is distinguishing itself from other powers, and modeling its behavior. An interesting case of this is the suggestion offered by Kōno in 2017 when speaking on combating violent extremism: "Unlike the United States or Europe, nobody has guns in Japan, and we know the importance of guns and weapons control” (2017). The statement distinguishes Japan's power from the West's, and presents it as a desirable (violence-free, harmonious, minpon-shugi) model - one whereby human security has been attained, thus coopting the listeners to these values. Does it effectively appeal to Muslim populations? A comment by 2011 Nobel Peace Prize Laureate and Yemeni journalist Tawakkol Karman provides a powerful response:

There are a lot of lessons we can learn from Japan as a country that overcame war, poverty, and natural disasters to become a peaceful country...The Yemeni people often look to Japan, rather than the United States or Europe, as a model to emulate when it comes to peace in particular, as well as economics and public safety (2014).

\section{Conduit for Dialogue and Leadership}

This section examines Japan's expressions of democratization and human rights in diplomatic initiatives in Muslim Asia. The two clearest cases are Corridor to Peace and 
Prosperity Initiative, and the Central Asia Plus Japan Dialogue. The Corridor to Peace and Prosperity Initiative seeks to build peace in Palestine by building confidence-building measures through multilateral collaboration and economic development. In the second case, the republics in Central Asia collectively represent some of the lowest levels of democratization and human rights in the world, yet Japan has had no qualms about cooperating with these states in a multilateral forum, the Central Asia Plus Japan Dialogue. Other political dialogues are also considered in the Middle East.

$$
\text { Japan and Palestinian Human Rights }
$$

Japan's position on the Israel-Palestinian Conflict has often been overlooked, but this has likely been the result of a decades-long deliberate strategy to keep a low profile in the midst of the conflict. When Israel declared its independence in 1948 and the first Arab-Israeli War broke out, Japan was still amid postwar occupation, was neither a sovereign nation, nor a UN member, and in no position to respond. Upon the end of postwar occupation, Japan established diplomatic relations with Israel in 1952 - the first of any Asian state to establish relations with Israel. The Israelis viewed this as a major victory, so that they could start making inroads to recognition and diplomacy in Asia, yet it did not turn out that way. In 1955, as a result of a "powerful plea" by Pakistan to have stronger anti-communist representation, Japan was member to the Bandung Conference of Asian and African states while Israel was banned from attending (Miyagi 2018, 1213). Japan supported the conference resolution stating:

[i]n view of existing tension in the Middle East, caused by the situation in Palestine and the danger of that tension to world peace, the Asian-African Conference declared its support of the rights of the Arab people of Palestine and called for the implementation of the United Nations Resolution on Palestine and 
the achievement of the peaceful settlement of the Palestine question (MOFA Indonesia 1955, 168).

For Japan, the Bandung Conference was an opportunity to showcase to Asian states that it had shed its colonial past, and stood in solidary with them as anti-colonialists. ${ }^{9}$ Thus, the plight of Palestinians was increasingly interpreted in Japan as rights of a people (de Boer 2005, 7). The following year, Israel invaded the Sinai Peninsula during the Suez Crisis, and Japan began distancing itself from Israel. In 1967, Japan was among the 99 states which favored UN General Assembly Resolution 2253 that condemned Israel's capture of East Jerusalem during the Six-Day War (the U.S. abstained).

Israel's military conquests garnered it a bellicose reputation in postwar Japan where pacifist norms were rapidly strengthening, but this reputation was turned upside down in May 1972 when a Japanese militant leftist group called the Japanese Red Army carried out a massacre at Lod Airport near Tel Aviv, killing 26 and injuring 78 (Kihara 2009, 218)..$^{10}$ The Japanese Red Army had been based in Lebanon after fleeing Japan, and allied with the Popular Front for the Liberation of Palestine (PFLP), a leftist Palestinian independence group. While Marxist in ideology, the Japanese Red Army was sucked into the Palestinian liberation conflict in the Middle East as a "means of survival" (Kihara 2009, 219). Japanese leaders and the public were in disbelief that three Japanese nationals carried out such an attack. Israel was understood as warring; Japan was understood as peaceful. While not directly responsible, the Japanese government issued a

\footnotetext{
${ }^{9}$ Sixty years later at the same place, Abe reiterated this objective for Japan: "Japan....resolved [in 1955] that among Asian and African countries seeking peace and prosperity under the Bandung principles, we should stand at the forefront" (2015b).

${ }^{10}$ Among the dead was Aharon Katzir, President of the Israeli National Academy of Sciences.
} 
public apology to the government of Israel, and offered $\$ 1$ million in retribution to the victims (most of whom were Puerto Rican) (Kihara 2009, 218). Shame led to Japan reassessing its view of Israel, and, to distance itself from the Japanese Red Army and PFLP, it distanced itself from the Palestinians. In January 1974, the Japanese Red Army and PFLP jointly sabotaged an oil refinery and then hijacked a ferryboat in Singapore, taking the crewmembers hostage. Days later Palestinian supporters of the Japanese Red Army and PFLP occupied the Japanese embassy in Kuwait City, taking the ambassador and staff hostage, to pressure Tokyo to obey the hostage takers' demands in Singapore for safe passage to South Yemen. Both hostage events were resolved without loss of life, but dampened empathy for the Palestinian cause among Japanese.

Concurrently, however, in 1973 Japan was forced to reaffirm its commitment to Palestinian self-rule amid the first oil shock. In a statement named after the Chief Cabinet Secretary, Nikaidō Susumu, the Nikaidō statement explained that Japan supported, "[t]he withdrawal of Israeli forces from all territories occupied in the 1967 war," and "[ $[$ the recognition of and respect for the legitimate rights of the Palestinian people" (Halloran 1973, 17). At the time, the Nikaidō statement was lauded because it "represented Japan's first major split on foreign policy with the United States in the postwar era" (Yergin 1993, 629), and it “marked Japan's most positive effort to take a pro-Arab stance on the Middle East," but both of these observations overlooked the fact the statement was the result of oil coercion, which clouded Japan's true outlook on Palestinian human rights (Halloran 1973, 17).

After the first oil shock, Japan's Israel-Palestine policy was based on a struggle of image, to maintain a positioning between, first, its alliance with the U.S., and, second, the 
appearance of neutrality from the perspective of Arab states. There is some precedence, however, of Japan supporting the Palestinians between the 1955 Bandung Conference and 1973. In 15 UN General Assembly, Security Council, and UNESCO resolutions relevant to the Israel-Palestine conflict from 1967 until 2017, Japan voted with the majority nine times and abstained six times, yet never cast the same vote as the U.S. As seen in Table 7.6, Japan has generally tended to abstain on resolutions regarding Palestinian statehood (although it did support granting Palestine UN-observer status in 2012), yet at the same time, it has tended to favor resolutions that condemn human rights abuses (although it did abstain on the 2009 Goldstone Report on human rights abuses in Gaza).

Despite the tendency to abstain on resolutions regarding Palestinian statehood, in May 2004 Japan clarified its support of the two-state solution, and has since then more clearly staked out its own position on the Israel-Palestine conflict (McGlynn 2009, 2-3). It remains restrained to the extent that it never has urged a reexamination of UN 242, even when it served on the Security Council, and tends to call on both sides as equal parties to work towards peaceful negotiations, at times seemingly oblivious to the level of enmity that has festered between the two sides. Observing only at this level, Japan appears to show limited direct engagement, but this easily overlooks the role Japan has played on the ground via ODA and dialogues.

Japan was admitted to the UN Relief and Works Agency for Palestine Refugees in the Near East (UNRWA) Advisory Commission in 1973, and would become a major donor to the program in the following decades. In July 2006, Prime Minister Koizumi introduced the Corridor for Peace and Prosperity as a strategy to combat the humanitarian 
crisis in Palestine, and facilitate an opportunity for regional peace through mutual prosperity. Initiated a few months prior to the declaration of the values-based Arc, the Corridor would serve as a cornerstone of Japan's new form of engagement in Asia. Beyond Koizumi, Asō, and Abe, several subsequent political elites continue to promote the Corridor initiative. The Corridor seeks to bring together four parties, Japan, Israel, Jordan, and Palestine, to collaborate on an agro-industrial park in the Jericho Governorate of the West Bank, and a transportation network from the West Bank through Jordan to the Gulf States. From the start, Japan has been prepared to finance the bulk of the initiative investment costs through ODA. In the fall of 2017, the first phase of the agroindustrial park was completed, with two more phases scheduled.

In 2009, together initially with Indonesia and Malaysia, Japan developed the Conference on Cooperation among East Asian Countries for Palestinian Development (CEAPAD), which has facilitated agricultural, industrial, and commercial training of Palestinians. At the 2013 conference in Tokyo, CEAPAD expanded to include Brunei, South Korea, Singapore, Thailand, Vietnam, the League of Arab States, Islamic Development Bank, UN, UNRWA, and World Bank. In the 2014 conference in Jakarta, it expanded to include 22 countries, including China. Through CEAPAD, Japan has more clearly articulated its support for a two-state solution. MOFA's website explains that CEAPAD was created "on the initiative of Japan to back up the realization of peace through the "two-state solution"” (2013). In 2013, Kishida spoke at the CEAPAD meeting: "I cannot stop hoping that when peace talks stall, Israel and Palestine will listen to the international community, and through a 'two-state solution' can begin to make progress towards realizing peace" (2013a). 
The Japanese position in the conflict is mostly motivated by an urge to support Palestinians on grounds of human rights and for stability and prosperity in Asia, but its behavior is influenced by the countering variables that are, firstly, its alliance with the U.S., and, secondly, necessity to retain steady access to energy resources from proPalestinian Arab states. Israel is an important trade partner for Japan with respect to specific fields, such as security technology, but it pales in comparison to Japan's economic interests with oil-rich Arab states. Alliance with the U.S., however, causes Japan to tread lightly with any political position regarding the Palestinian question. Indeed, Japan is among just a handful of Asian states that does not recognize the state of Palestine, but in early 2018, after meeting with Japanese diplomats, PNA senior official Nabil Shaath told Saudi newspaper Al-Watan that "Japan is preparing to enter the process of recognizing a Palestinian state" (Shaath 2018). This statement has garnered attention in the Middle East media, but little in Japan or the West. In any case, the geopolitical and economic pressures on Japan force it to focus its role in the conflict on humanitarian assistance toward the Palestinians. Therefore, the Japanese position on the IsraeliPalestinian conflict is foremost a human rights position.

\section{Central Asia Plus Japan Dialogue}

In his seminal work Great Games, Local Rules, Alexander Cooley argues that the five Central Asian republics display "few tangible indicators of actual regional coherence" (2012: 149). Trade within the region is constrained, human mobility is restricted with most emigrating laborers going to Russia before a neighboring Central Asian republic, and public agencies often refuse to share information with each other (Cooley 2012, 149-50). Both Beijing and Moscow have concentrated efforts to deepen 
not only their own relations with the Central Asian republics, but also the integration among the five republics. Yet, these attempts are always done without the full participation of all five states, and with Chinese or Russian interests at the root of the strategic engagement. In some capacity, a plurality of Central Asian republics are party to the Commonwealth of Independent States, the Organization for Security and Cooperation in Europe, the Shanghai Cooperation Organization, the Eurasian Economic Union, and the Collective Security Treaty Organization, and several other international organizations. More often than not, however, these organizations are either dominated by Russian, Chinese, or EU interests, or they are too large to focus on the issues specific to Central Asia, and opportunities for progress on regional integration have little chance.

The Central Asia Plus Japan Dialogue does provide opportunities for multilateral diplomatic engagement specific to Central Asia, as a region, which these other international organizations do not. The Central Asia Plus Japan Dialogue started in August 2004 as a foreign ministers' meeting, and has continued with subsequent meetings every year. Party to the Central Asia Plus Japan Dialogue are Japan, Kazakhstan, Kyrgyzstan, Uzbekistan, and Tajikistan. While not an official member, 'permanently neutral' Turkmenistan almost always sends a delegate with observer status, and has occasionally hosted the meetings as well. This is not to say the Central Asia Plus Japan Dialogue has been extraordinarily successful in achieving regional integration (or, for that matter, improving democratization and human rights), but in none of these other international organizations can high-level officials from all five Central Asian republics gather with just one member from outside the region, thus making up five-sixths of the 
parties represented. Moreover, that one outside member is not Russia or China; rather, it is a democratic Asian state with a strong human rights record.

At the first Dialogue in 2004, Japanese Foreign Minister Kawaguchi Yoriko made this objective explicitly clear: "I would like to emphasize the crucial nature of the development of human rights and democratization in Central Asia” (Kawaguchi 2004). She added, "I believe strongly that human rights and democracy can be realized within each country's cultural and historical context, and in this area, too, Japan hopes to be able to contribute its experiences and its knowledge" (2004). A review of the Central Asia Plus Japan Dialogue foreign ministers' joint statements from 2004 to 2017, however, shows few references to democracy, and even less references to human rights, rule of law, or market economy (see Table 7.7). References to democracy and human rights have vanished in both bilateral and multilateral diplomacy between Japan and the Central Asian republics with the exception of Kyrgyzstan, the only semi-democratic state in the region. In April 2017, Foreign Minister Kishida wrote five nearly-identical columns for one newspaper in each of the five Central Asian republics. As seen in Table 7.7, of the five, democracy was mentioned in Turkmenistan, Uzbekistan, and Kyrgyzstan, but omitted from the columns of mostly the same content in Kazakhstan and Tajikistan. Yet, in the three cases it was mentioned, all three were referencing Kyrgyzstan's progress as a model. References to democracy are constrained, and the few times it is mentioned, it is to point out the successes in Kyrgyzstan, never the dearth elsewhere in the region.

Nonetheless, the Central Asia Plus Japan Dialogue is the only forum in which “almost exclusively, Central Asians [are] discussing Central Asian matters" (Barber 2018, 32). Cooley notes the rows that exist among Central Asian political elites: 
Officials from Kazakhstan frequently complain about being grouped with its relatively weaker and poorer neighbors, while Uzbekistan consistently expresses a preference for addressing regional problems through bilateral means, rather than multilateral or regional organizations. Turkmenistan's long-standing "policy of neutrality" allows Ashgabat to altogether avoid making formal commitments to outside powers, regional forums, or international organizations (2012: 151).

Yet surprisingly, the Central Asia Plus Japan Dialogue brings them together, and Tokyo is able to provide a facilitator role which does not raise the suspicion of any of the Central Asian administrations that it is like Beijing or Moscow, and vying for geopolitical influence in the region. It is not a forum whereby Tokyo announces ODA packages, since these are normally done bilaterally, but it is where Japan inserts its solutions to issues in Central Asia. Abe explained his view of the Central Asia Plus Japan Dialogue while in Kazakhstan in 2015: "if something - an issue - calls for a regional solution, then Japan can be a 'catalyst' that all parties trust" (Abe 2015d).

\section{Other Dialogues}

It was Iranian President Mohammed Khatami who introduced the initiative, Dialogue Among Civilizations, to the UN in 2000. It was Japan which acted on it. Along with the aforementioned, other political dialogues between Japan and Muslim Asia also exist. The Iran-Japan Human Rights Dialogue started the same year as Khatami’s initiative, and continues at the foreign minister and vice foreign minister level. Over a dozen conferences have taken place in rotation between Tokyo and Tehran, but joint statements are not released and little detail is provided regarding the content of these dialogues. Also, in 2017, the Japan-Arab Political Dialogue commenced, succeeding the

Dialogue among Civilizations between Japan and the Islamic World (2002-2010), and the Japan-Arab Dialogue Forum (2003-2006). Dialogues appear to be the clear strategic 
option for Japan, but it is questionable how effective are these dialogues with opaque outcomes.

Would Central Asian republics be less democratic and have worse human rights records if the Central Asia Plus Japan Dialogue never took place? Is the Iran-Japan Human Rights Dialogue having any effect on human rights in that country? No significant outcome on democratization or positive effect on human rights is evident, but at the same time, they are conduits for Japan to model its values. Japan may not be asking the hard questions on democratization and human rights as the West would, nor does it necessarily broach the topic - to do so would be inharmonious - but it is implied in nonverbal, indirect communication characteristic of the Japanese language. To be direct is rude and confrontational; rather, onus is on the listener to interpret implied meanings "to read the air" (ba no küki wo yomu). An example of this is the indirect reference to Kyrgyzstan's progress in democratization by Kishida in Uzbekistan and Turkmenistan. Therefore, consistent dialogues are maintained with Muslim Asian states in order to strengthen awareness of Japan, and its values. The strategy is to model. Perhaps the effect is marginal, but is that any less effective than the West's tough questions approach?

\section{Human Rights and the Syrian Refugee Crisis}

The Arab Spring of 2011 caught Japan considerably off guard. Whereas in the West it was seen as both a demand for democratization and an opportunity to shape it into the Western liberal democracy model, Japan was in a poor position to respond during the most fervent events. On March 11, the Tōhoku Earthquake and Tsunami struck the country, and crippled it with the Fukushima nuclear disaster looming. Four days later, on March 15, the 'day of rage' started in Syria, whereby Arab Spring demonstrations were 
met with open fire from security forces. Support for the protestors was expressed throughout the West, but Japan's foreign minister did not issue any statement for a full week. Fuel prices, not the promotion of democracy, were of vital concern for Tokyo due to the events in both Japan and the Middle East.

In the months that followed, tens of thousands of refugees fled Syria due to an intensifying civil war. By 2018, the number would surpass 6 million (Connor 2018). Most refugees abroad settled in neighboring countries, but as refugee numbers continued to swell, countries all over the world were faced with the challenge of resettling Syrian refugees in their countries. Among the developed world, the Japanese response to refugee crises has been unique for decades. Japan is a signatory to the Convention Relating to the Status of Refugees in 1981 and the Protocol relating to the Status of Refugees in 1982, but in major refugee crises, while Japan tends to provide substantial humanitarian assistance, it also admits very few refugees to resettle in Japan. This would again be the case.

Intense debates over accepting Syrian refugees have taken place in Western countries. The large majority of Syrian refugees are Muslims, and thus, an urge to securitize is obvious, for fear that refugee programs are welcoming religious terrorists into Western societies. Since the civil war began, half a million Syrians were admitted as refugees into Germany - the most of any country not bordering Syria. Among other G7 members, Canada has admitted over 50,000; the U.S., 20,000; the UK and France, over 10,000, each; and Italy has admitted 2,500 (Connor 2018). Yet for the seventh member of the G7, Japan, only seven Syrian refugees were allowed entry (Yamagata 2017, 1). Even after substantial pressure from its Western G7 partners, Japan announced it would accept 
just 150 Syrian refugees as students over five years, starting in 2017 (Yamagata 2017, 5). Somehow, Japan gets a pass on the burden of accepting refugees by the global media, and little debate takes place on the issue in Japan. When presented with the issue a wellknown writer in Japan, Sono Ayako, commented that "Japanese people do not know how difficult it is for people who have different backgrounds, religions, cultures and physical appearance to live together" (Yamagata 2017, 9).

In September 2015, political cartoonist Hasumi Toshiko shared an illustration of a Syrian refugee girl on Facebook that caught the attention of many, both in Japan and abroad. The cartoon was based on a photograph taken of a six-year old Syrian girl by a photographer working with Feed the Children at a refugee camp in Lebanon. Hasumi's illustration distorted the intended meaning of the photograph by adding a menacing glare to the girl's eyes, and including thought bubbles. The thought bubbles start innocuously enough, written in Japanese: "I want to live in safety. I want to be sent to a life that is pure. I want delicious food. I want to play freely. I want to dress up. I want to live in luxury. I want to go where I can live without hardship.” Then, in much larger text, "at someone else's cost! I got it...I'll be a refugee!” A few months later, Hasumi published an illustration book, Sōda Nanmin Shiyō - Hasumi Toshiko no Sekai (I'll Be a Refugee! The World of Hasumi Toshiko), which included a modified version of the controversial Syrian girl illustration on the cover.

Hasumi's illustration does not wholly represent a national mood towards human rights with regard to refugees. In fact, numerous Japanese joined non-Japanese who decried the illustration and its message. It is difficult to argue, however, that it does not express a prevalent theme in Japanese thinking, when Japan consistently deflects 
admission of refugees into the country. Just days after Hasumi uploaded her illustration, Abe addressed why Japan does not accept but a handful of refugees: "[b]efore accepting immigrants or refugees, we need to have more activities by women, by elderly people and we must raise [the birthrate]" ( $B B C$ 2015). The same month, Abe pledged $\$ 810$ million to aid Syrian and Iraqi refugees while speaking at the UN General Assembly (BBC 2015).

Abe, has never made a public statement regarding Hasumi's illustration, and it would not be expected for a government official to comment on such, but there is a common theme between them in terms of securitization to note. In both cases, the threat is not terrorism, as it is in the West, but rather, a threat to Japan's economic security. Checkbook diplomacy fills the void of humanitarian obligation, and secures the referent object (Japan's economy) from the threat (immigrants). Therefore, this is not Islam as the threat, as it is perceived to be in the West with a Trojan horse narrative. It does, however, have a negative effect on perceptions of Japan by both Muslims who share religious identity with Syrian refugees, and the wider international community. A year later, in September 2016, Japan announced a new aid package of $\$ 2.8$ billion over the course of three years at the UN Summit for Refugees and Migrants. Japan unequivocally makes generous contributions for refugees and several Japanese NGOs are active in aid efforts for Syrian refugees, but expectations are made, norms are constructed, and comparisons are drawn among DAC members, and despite whatever large amount of ODA packages Japan contributes, it remains conspicuous for its petty acceptance of refugees into its country. This can be noted of course by Syrians in need, but also DAC members and Muslims across Asia. 


\section{Conclusion}

In June 1957, Prime Minister Kishi addressed the U.S. House of Representatives, stating:

"It is because of our strong belief in democratic principles and ideals that Japan

associates herself with the free nations of the world." In April 2015, his grandson, Abe

Shinzō, spoke the same words, at the same podium, holding the same office. There are multiple impetuses why democracy, human rights, and other values are expressed, in the

manner which they are expressed, in Japan's foreign policy with Muslim Asia. These can be expressed in two framings.

First, the geopolitical perspective is undeniable, but also incomplete. According to this perspective, Japan is using an ideational strategy for material interests. This is namely a counterstrategy regarding a rising China. In May 2012, a minor row erupted when, to Beijing's chagrin, Japan decided to host the World Uyghur Congress (WUC) general assembly in Tokyo. Weeks prior to the general assembly, Beijing sent a letter to several parliamentarians in Japan, including Abe, requesting Japan to not have any contact with WUC. While geopolitical interests were obvious to any observer, the WUC and Japanese used the opportunity to express a shared geoculture. The WUC seeks to create a democratic state in East Turkistan from the present Xinjiang Autonomous Region in China, and denounces any violence in their protests - both of which pleases Tokyo, but rousing Beijing was possibly more pleasing.

When WUC leader Rebiya Kadeer visited Tokyo, she irritated Beijing even further by making a visit to the controversial Yasukuni Shrine - a Shinto site that honors spirit including wartime Class-A war criminals. When asked about it, she called it a "a cultural [visit], not a political act," thus highlighting the constructed geoculture between 
the WUC and Japan. Nonetheless, the geopolitical aspects are difficult for any observer to dismiss (Hammond 2013). In fact, the geocultural language may be no more than a smokescreen to conceal the overt geopolitical interests on both sides. It does, however, do more for Tokyo insofar as the plight of the WUC is of interest to much of Muslim Asia, and Japan's support of the organization facilitates for trust-building.

This chapter demonstrates that references to rule of law are more often than not pointing toward maritime international law, and the South China Seas. It is not about order within states in Muslim Asia. Japan is framing itself as the model of an Asian, democracy, free society who respects human rights. This language constructs Japan as a model to appeal to Muslim Asia just as it did in the early twentieth century as a model to modernize, but not Westernize. Yet, at the same time, this distinguishes Japan from China, and to a lesser extent, Russia. It does not distinguish Japan from the West, but that is where the 'Asian values' come into play.

Second, it is obvious there is much more at play in values-based diplomacy than just geopolitics. Japan is hedging that its 'Asian liberal democracy,' with 'Eastern values' such as harmony, moderation, tolerance, lovingkindness, and benevolence, coupled together with 'universal' or 'basic values' of freedom, human rights, rule of law, and market economy is the right path to peace, prosperity, stability, and attainment of minpon-shugi in practice. Minpon-shugi is people-based, but it is also security, quality of life, social harmony, benevolence - it is human security, which is the essence of desire for peoples throughout wide swaths of Muslim Asia. To spread this message is a significant transformation for Japan. There is a conviction of how development needs to take place in Asia, and this is based on its own historical experiences. The point is not so 
much to be right or wrong about this conviction as it is evident in their belief. Therefore, it is essential for Japan's strategy for Asia, including Muslim Asia.

Where does Islam and securitization fit into this? Japan is not blending itself fully into Asia. This is evident from the examination of the refugee case. It sees itself, however, as part of the same sub-structure system, and a model that is replicable precisely because of likeness. Islam is addressed through expressions of moderation and tolerance, and through the belief that economic growth leads to peace, prosperity, stability, and lessens the possibility of violent religious extremism. The conclusion is evident from both the ODA activities examined in the previous chapter as well as the statements examined in this one. 
Figure 7.1: Abe's Framing of "Asian Values," at Shared Values and Democracy in Asia Symposium, Tokyo, January 2016

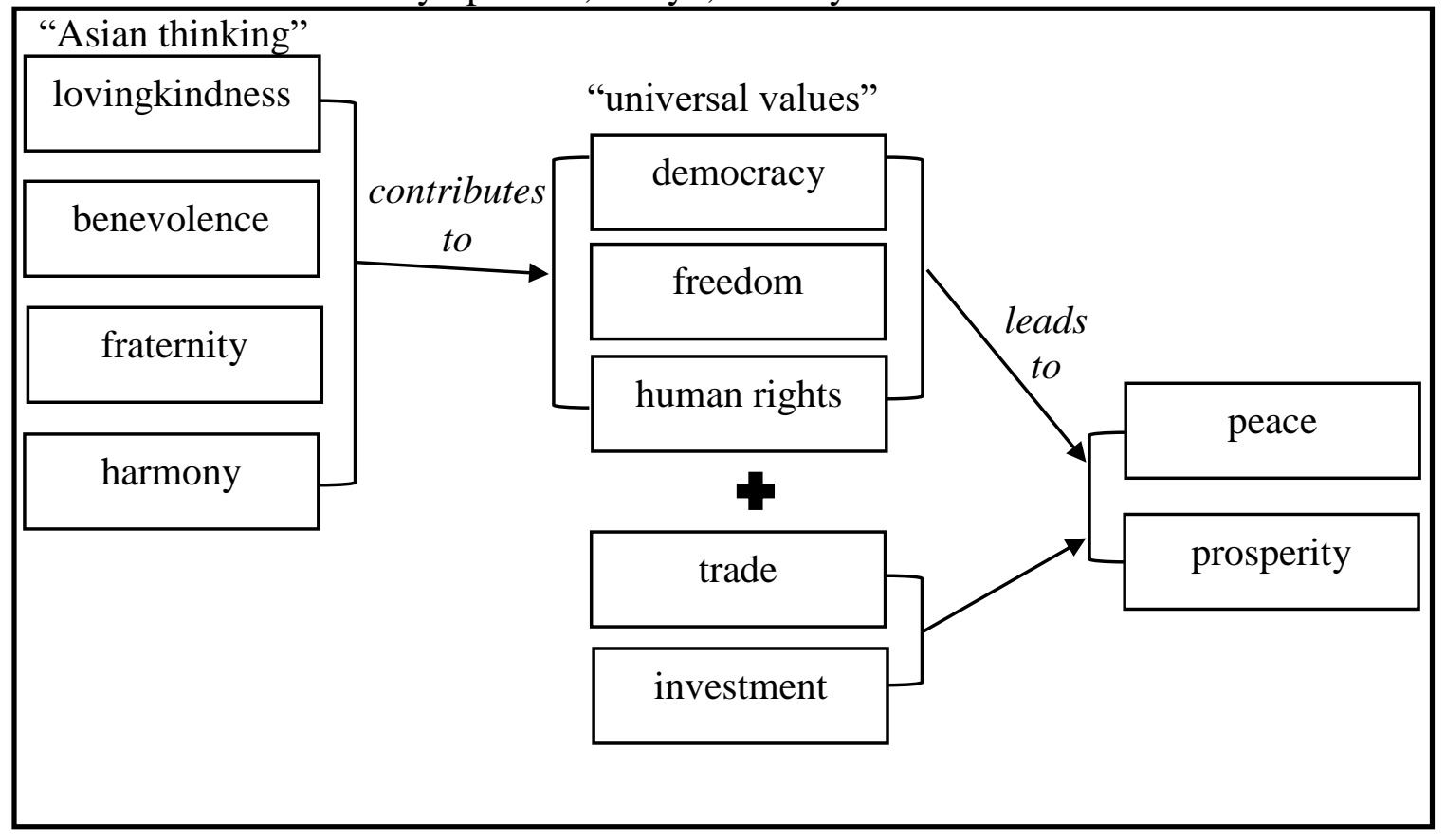


Table 7.1: Japanese Elites' References to 'Democracy' in Muslim Asia, 2013-2018

\begin{tabular}{|c|c|c|c|c|}
\hline date & diplomat & place & forum & context (times) \\
\hline 18 Jan. 2013 & Abe & Indonesia & Speech & $\begin{array}{l}\text { Indonesia's (2); } \\
\text { Japan's (1) }\end{array}$ \\
\hline 3 May 2013 & Abe & Turkey & Press conference & $\begin{array}{l}\text { “...in Middle East” } \\
\text { (1) }\end{array}$ \\
\hline 24 Aug 2013 & Abe & Saudi Arabia & $\begin{array}{l}\text { Newspaper } \\
\text { interview }\end{array}$ & $\begin{array}{l}\text { regarding situation in } \\
\text { Egypt (1) }\end{array}$ \\
\hline 25 Aug 2013 & Abe & Kuwait & $\begin{array}{l}\text { Newspaper } \\
\text { interview }\end{array}$ & $\begin{array}{l}\text { regard situation in } \\
\text { Egypt (1) }\end{array}$ \\
\hline 27 Aug 2013 & Abe & Qatar & $\begin{array}{l}\text { Newspaper } \\
\text { interview }\end{array}$ & $\begin{array}{l}\text { “....in Middle East” } \\
\text { (1) }\end{array}$ \\
\hline 28 Aug 2013 & Abe & Qatar & Press conference & $\begin{array}{l}\text { Japan's counter- } \\
\text { terrorism strategy (1) }\end{array}$ \\
\hline 21 Mar 2014 & Kishida & Bangladesh & $\begin{array}{l}\text { Newspaper } \\
\text { column }\end{array}$ & $\begin{array}{l}\text { Bangladesh's } \\
\text { progress in... (1) }\end{array}$ \\
\hline $16 \mathrm{Jul} 2014$ & Kishida & Kyrgyzstan & $\begin{array}{l}\text { Newspaper } \\
\text { column }\end{array}$ & $\begin{array}{l}\text { Kyrgyzstan's } \\
\text { progress in... (2) }\end{array}$ \\
\hline 12 Aug 2014 & Kishida & Indonesia & $\begin{array}{l}\text { Newspaper } \\
\text { interview }\end{array}$ & $\begin{array}{l}\text { Japan \& Indonesia's } \\
\text { shared values (2) }\end{array}$ \\
\hline 26 Oct 2015 & Abe & Kyrgyzstan & $\begin{array}{l}\text { Newspaper } \\
\text { interview }\end{array}$ & $\begin{array}{l}\text { Japan \& Kyrgyzstan's } \\
\text { shared values (2) }\end{array}$ \\
\hline 21 Nov 2015 & Abe & Malaysia & $\begin{array}{l}\text { Newspaper } \\
\text { interview }\end{array}$ & $\begin{array}{l}\text { Japan \& Malaysia's } \\
\text { shared values ( } 3 \text { ) }\end{array}$ \\
\hline 15 Jan 2017 & Abe & Indonesia & $\begin{array}{l}\text { Newspaper } \\
\text { interview }\end{array}$ & $\begin{array}{l}\text { Japan \& Indonesia's } \\
\text { shared values (1) }\end{array}$ \\
\hline 29 Apr 2017 & Kishida & Turkmenistan & $\begin{array}{l}\text { Newspaper } \\
\text { column }\end{array}$ & $\begin{array}{l}\text { Referencing } \\
\text { Kyrgyzstan's...(3) }\end{array}$ \\
\hline 30 Apr 2017 & Kishida & Uzbekistan & $\begin{array}{l}\text { Newspaper } \\
\text { column }\end{array}$ & $\begin{array}{l}\text { Referencing } \\
\text { Kyrgyzstan's...(3) }\end{array}$ \\
\hline 30 Apr 2017 & Kishida & Kyrgyzstan & $\begin{array}{c}\text { Newspaper } \\
\text { column }\end{array}$ & $\begin{array}{l}\text { Referencing } \\
\text { Kyrgyzstan's...(3) } \\
\end{array}$ \\
\hline
\end{tabular}


Table 7.2: Japanese Elites' References to 'Human Rights' in Muslim Asia, 2013-2018

\begin{tabular}{cccll}
\hline date & diplomat & place & \multicolumn{1}{c}{ forum } & \multicolumn{1}{c}{ context (times) } \\
\hline 18 Jan. 2013 & Abe & Indonesia & Speech & Indonesia's strong record (1) \\
24 Aug 2013 & Abe & Saudi Arabia & Newspaper interview & in regard to Egypt (1) \\
25 Aug 2013 & Abe & Kuwait & Newspaper interview & in regard to Egypt (1) \\
26 Oct 2015 & Abe & Kyrgyzstan & Newspaper interview & $\begin{array}{l}\text { Japan \& Kyrgyzstan's shared } \\
\text { values (1) }\end{array}$ \\
21 Nov 2015 & Abe & Malaysia & Newspaper interview & $\begin{array}{l}\text { Japan \& Malaysia's shared } \\
\text { values (3) }\end{array}$ \\
& Abe & Indonesia & Newspaper interview & Japan \& Indonesia's shared \\
15 Jan 2017 & Abes (1) & & values \\
19 Nov 2017 & Kōno & Bangladesh & Newspaper interview & Regarding Rohingya crisis (1) \\
\hline
\end{tabular}

Table 7.3: Japanese Elites' References to 'Rule of Law' in Muslim Asia, 2013-2018

\begin{tabular}{|c|c|c|c|c|}
\hline date & diplomat & place & forum & context (times) \\
\hline 18 Jan. 2013 & Abe & Indonesia & Speech & $\begin{array}{l}\text { Indonesia's record (1); open } \\
\text { seas (1) }\end{array}$ \\
\hline 24 Aug 2013 & Abe & Saudi Arabia & Newspaper interview & in regard to Egypt (1) \\
\hline 25 Aug 2013 & Abe & Kuwait & Newspaper interview & in regard to Egypt (1) \\
\hline 8 Oct 2013 & Abe & Brunei & Newspaper interview & South China Sea (1) \\
\hline 10 Oct 2013 & Abe & Brunei & Press conference & open seas (1) \\
\hline 12 Aug 2014 & Kishida & Indonesia & Newspaper interview & open seas (1) \\
\hline 6 Sep 2014 & Abe & Bangladesh & Newspaper interview & $\begin{array}{l}\text { Japan's approach to int'l } \\
\text { conflicts (1) }\end{array}$ \\
\hline 22 Apr 2015 & Abe & Indonesia & Newspaper interview & $\begin{array}{l}\text { Referencing Bandung } \\
\text { Principles (1) }\end{array}$ \\
\hline 5 Aug 2015 & Kishida & Malaysia & Newspaper interview & South China Sea (1) \\
\hline 26 Oct 2015 & Abe & Kyrgyzstan & Newspaper interview & $\begin{array}{l}\text { Japan \& Kyrgyzstan's shared } \\
\text { values (1) }\end{array}$ \\
\hline 21 Nov 2015 & Abe & Malaysia & Newspaper interview & $\begin{array}{l}\text { Japan \& Malaysia's shared } \\
\text { values (3); open seas (1) }\end{array}$ \\
\hline 22 Nov 2015 & Abe & Malaysia & Press conference & $\begin{array}{l}\text { shared values with U.S. (1); } \\
\text { open seas (1) }\end{array}$ \\
\hline 15 Jan 2017 & Abe & Indonesia & Newspaper interview & $\begin{array}{l}\text { Japan \& Indonesia's shared } \\
\text { values (1) }\end{array}$ \\
\hline 11 Feb 2018 & Kōno & Brunei & Newspaper column & open seas (1) \\
\hline
\end{tabular}


Table 7.4: Appearance of Terms in Strings in Japan Diplomatic Bluebooks, 2013-2017

\begin{tabular}{ccccccc}
\hline Edition & $\begin{array}{c}\text { total } \\
\text { strings }\end{array}$ & democracy & $\begin{array}{c}\text { human } \\
\text { rights }\end{array}$ & rule of law & $\begin{array}{c}\text { freedom/ } \\
\text { liberty }\end{array}$ & $\begin{array}{c}\text { market } \\
\text { economy }\end{array}$ \\
\hline 2013 & 6 & 5 & 3 & 3 & 1 & 3 \\
2014 & 13 & 10 & 9 & 7 & 10 & 0 \\
2015 & 22 & 18 & 13 & 16 & 12 & 3 \\
2016 & 26 & 22 & 16 & 19 & 15 & 3 \\
2017 & 23 & 18 & 15 & 13 & 11 & 5 \\
TOTAL & 90 & 73 & 56 & 58 & 49 & 14 \\
\hline
\end{tabular}


Table 7.5: Utterance Frequency of Select Terms by Japanese Elites' in Muslim Asia, 2013-2018

\begin{tabular}{llcc}
\hline & Term & Frequency & Coverage \\
\hline 支援 (shien) “assistance” & 262 & $0.56 \%$ \\
安定 (antei) “stability” & 207 & $0.44 \%$ \\
発展 (hatten) “development” & 191 & $0.41 \%$ \\
平和 (heiwa) “peace” & 171 & $0.37 \%$ \\
成長 (seicho) “growth” & 127 & $0.27 \%$ \\
繁栄 (han'ei) “prosperity” & 110 & $0.24 \%$ \\
技術 (gijutsu) “skill/technique” & 106 & $0.23 \%$ \\
貢献 (kōken) “contribution” & 102 & $0.22 \%$ \\
投資 (tōshi) “investment” & 98 & $0.21 \%$ \\
インフラ (infura) “infrastructure” & 86 & $0.18 \%$ \\
エネルギー (enerugī) “energy” & 83 & $0.18 \%$ \\
テロ (tero) “terrorism” & 72 & $0.15 \%$ \\
民主 (minshu) “democracy” & 52 & $0.11 \%$ \\
人権 (jinken) “human rights” & 17 & $0.04 \%$ \\
\hline
\end{tabular}


Table 7.6: Comparison of Japan and U.S. Voting Records on UN Resolutions Regarding Israel and Palestine

\begin{tabular}{|c|c|c|c|}
\hline Resolution & Japan & U.S. & Outcome \\
\hline $\begin{array}{l}\text { UNGA Res. 2253: condemns Israel's capture of } \\
\text { East Jerusalem } \\
\text { July } 1967\end{array}$ & In favor & Abstains & $\begin{array}{l}99 \text { in favor } \\
0 \text { against } \\
20 \text { abstentions }\end{array}$ \\
\hline $\begin{array}{l}\text { UNGA Res. 3236: recognition of Palestinian right } \\
\text { to self-determination } \\
\text { November } 1974\end{array}$ & Abstains & Against & $\begin{array}{l}89 \text { in favor } \\
8 \text { against } \\
37 \text { abstentions }\end{array}$ \\
\hline $\begin{array}{l}\text { UN observer status for Palestine } \\
\text { November } 1974\end{array}$ & Abstains & Against & $\begin{array}{l}95 \text { in favor } \\
17 \text { against } \\
19 \text { abstentions }\end{array}$ \\
\hline $\begin{array}{l}\text { UNGA Res. 3379: Zionism is a form of racism } \\
\text { November } 1975 \text { (repealed } 16 \text { years later) }\end{array}$ & Abstains & Against & $\begin{array}{l}72 \text { in favor } \\
35 \text { against } \\
32 \text { abstentions } \\
\end{array}$ \\
\hline $\begin{array}{l}\text { UNESCO Res. condemning Israel over Palestinian } \\
\text { rights } \\
\text { May } 1976\end{array}$ & In favor & Against & $\begin{array}{l}26 \text { in favor } \\
1 \text { against } \\
10 \text { abstentions }\end{array}$ \\
\hline $\begin{array}{l}\text { UNSC Res. 608: calls upon Israel to cease } \\
\text { deportation during first Intifada } \\
\text { January } 1988\end{array}$ & In favor & Abstains & $\begin{array}{l}14 \text { in favor } \\
0 \text { against } \\
1 \text { abstention }\end{array}$ \\
\hline $\begin{array}{l}\text { UNGA Res. } 4321: \text { amid the first Intifada, calls on } \\
\text { Israel to withdraw from occupied territories } \\
\text { November } 1988\end{array}$ & In favor & Against & $\begin{array}{l}130 \text { in favor } \\
2 \text { against } \\
16 \text { abstentions }\end{array}$ \\
\hline $\begin{array}{l}\text { UNGA Res. 43177: acknowledges Palestinian } \\
\text { statehood } \\
\text { December } 1988\end{array}$ & Abstains & Against & $\begin{array}{l}104 \text { in favor } \\
2 \text { against } \\
36 \text { abstentions }\end{array}$ \\
\hline $\begin{array}{l}\text { UNGA Res. 9427: grants Palestine rights to } \\
\text { participate in General Assembly } \\
\text { July } 1998\end{array}$ & In favor & Against & $\begin{array}{l}124 \text { in favor } \\
4 \text { against } \\
10 \text { abstentions }\end{array}$ \\
\hline $\begin{array}{l}\text { UNSC Res. 1860: calls for a ceasefire in Gaza } \\
\text { January } 2009\end{array}$ & In favor & Abstains & $\begin{array}{l}14 \text { in favor } \\
0 \text { against } \\
1 \text { abstention }\end{array}$ \\
\hline $\begin{array}{l}\text { UNGA Res. in support of the Goldstone Report in } \\
\text { Gaza } \\
\text { November } 2009\end{array}$ & Abstains & Against & $\begin{array}{l}114 \text { in favor } \\
18 \text { against } \\
44 \text { abstentions } \\
\end{array}$ \\
\hline $\begin{array}{l}\text { UNESCO full membership for Palestine } \\
\text { October } 2011\end{array}$ & Abstains & Against & $\begin{array}{l}107 \text { in favor } \\
14 \text { against } \\
52 \text { abstentions } \\
\end{array}$ \\
\hline $\begin{array}{l}\text { UNGA to grant Palestine observer state status } \\
\text { November } 2012\end{array}$ & In favor & against & $\begin{array}{l}138 \text { in favor } \\
9 \text { against } \\
41 \text { abstentions }\end{array}$ \\
\hline $\begin{array}{l}\text { UNSC Res. } 2334 \text { condemning Israeli settlements } \\
\text { in Palestinian territories } \\
\text { December } 2016\end{array}$ & In favor & Abstains & $\begin{array}{l}14 \text { in favor } \\
0 \text { against } \\
1 \text { abstention }\end{array}$ \\
\hline $\begin{array}{l}\text { UNGA nonbinding res. condemning U.S. move of } \\
\text { embassy to Jerusalem } \\
\text { December } 2017\end{array}$ & In favor & Against & $\begin{array}{l}128 \text { in favor } \\
9 \text { against } \\
35 \text { abstained }\end{array}$ \\
\hline
\end{tabular}


Table 7.7: Central Asia Plus Japan Dialogue Foreign Ministers' Meeting Joint Statement References to 'Democracy' or 'Human Rights,' 2004-2017

\begin{tabular}{ccccc}
\hline date & democracy & human rights & rule of law & $\begin{array}{c}\text { market } \\
\text { economy }\end{array}$ \\
\hline 28 Aug. 2004 & 3 & 0 & 0 & 1 \\
5 Jun 2006 & 1 & 1 & 0 & 2 \\
7 Aug 2010 & 1 & 0 & 0 & 0 \\
10 Nov 2012 & 2 & 1 & 1 & 2 \\
16 Jul 2014 & $1^{*}$ & 0 & 1 & 0 \\
1 May 2017 & 0 & 0 & 1 & 0 \\
\hline
\end{tabular}

* Regarding Afghanistan; not Central Asian republics. 


\section{CHAPTER VIII}

\section{SANCTIONS AND INTERVENTIONS}

In 1951, the UK called for an international embargo on Iranian crude oil after its prime minister nationalized the oil fields. The sudden nationalization of Iranian crude oil came directly to the detriment of the British Anglo-Iranian Oil Company (AIOC), which had control over essentially the entire oil industry in Iran for nearly two decades, and had concession contracts up until 1993 (Luttrell 2015, 203). Despite this, in February 1953 Japanese oil company, Idemitsu, made a nine-year contract with National Iranian Oil Company (NIOC), and Idemitsu's tanker, Nisshō Maru, left the port of Abbadan with a full load of 22,000 barrels of crude oil in March (Kubota 2009, 242-43). Not only did Idemitsu act in violation of the British-led embargo, but it also purchased the crude from Iran at 30 percent below market value, thus further vexing AIOC (Kubota 2009, 242).

A year prior, an Italian tanker carrying Iranian oil was intercepted by the British Royal Navy and escorted to British-held port of Aden, where the AIOC successfully argued in Aden prize court that it was the rightful owner of the cargo (Luttrell 2015, 203). The British Royal Navy's gunboat diplomacy and AIOC's active litigation in court dissuaded other tankers and effectively sealed off oil exports from Iran. Yet, the Nisshō Maru risked interception by the Royal Navy and safely arrived at the port of Kobe weeks later. AIOC promptly sued Idemitsu in Japanese courts, claiming ownership of the cargo, but Idemitsu would inevitably win in court. Reportedly, the Nisshō Maru was sent off by a cheering crowd in Iran, and greeted with cheering crowd in Japan, as it represented an act of defiance of the supermajors and Western powers. 
Idemitsu was criticized not only by the British and supermajors, but also many government officials in Japan, yet the move was widely popular among the Japanese public. Idemitsu "was one of only a handful of companies" that challenged the British call to boycott Iranian oil (Azimi 2010). The president of the company, Idemitsu Sazō, who made the decision to send the Nisshō Maru for a delivery, would comment later:

In the beginning, as a Japanese I considered it wrong to do something like ignoring international loyalty, so I endured [italics added] for a year and a half. Why I decided to do it was because the UK and the U.S. were looking to make a distributor to sell Iranian oil. I thought, "this is my chance" (Kubota 2009, 241).

A pragmatic businessman, Idemitsu added, "It was a buyer's market” (Kubota 2009, 242)! The Nisshō Maru Incident, as it is called in Japan, would spearhead a new era of direct relations between Muslim Asia and Japan. While 22,000 barrels was not a large figure in the grand scheme of Iranian crude sales and Japanese consumption, it carried great symbolic value. "It was Japan who was the first to unload Iranian oil out from the control of the international oil cartel" (Kubota 2009, 243). It is noteworthy in Idemitsu's statement how he endured the embargo for a year and a half as a Japanese, and thus, as a loyal member of an international community, yet the impetus to act was the risk of an economic monopoly on his industrial product. This acceptance of endurance as a loyal member of an international community as a Japanese is consistent with attitudes on sanctions of states in Muslim Asia up into the twenty-first century. It also illustrates, however, a threshold to that international loyalty that is based on economic self-interest, and by extension, national security concerns. Idemitsu acted when he sensed Japan's security would worsen due to the direction the UK and U.S. were leading this sanction regime. 
Idemitsu's statement reflected a struggle between Japan's own interests, and perceived role as an upright model state in the international society. This struggle persists today, and relates to how Japan has responded to sanctions and interventions in Muslim Asia. If values such as democratization, human rights, and rule of law are now emphasized and proselytized in Japan's foreign policymaking, there must be consideration of the punitive mechanisms to deal with states that egregiously defy such values. That is not to say Japan actively desires to be the actor who carries out such punitive mechanisms, but options such as economic sanctions and armed interventions must be in the toolbox. This chapter considers Japan's position on economic sanctions and armed interventions in Muslim Asian states, as it relates to its values-based diplomacy and securitization of Islam. Insofar as securitization is the "identification of an existential threat to a valid referent object and the call for exceptional measures," the U.S., its view of Islam, macrosecuritization, and its vision for Asia are significant factors in consideration of Japan's position on sanctions and interventions in Muslim Asia, but Japan also has its own normative predispositions that are expressed (Buzan and Wæver 2009, 257). These norms also have to be balanced in Japan's strategy.

This chapter examines Japan's perceived role in Muslim Asia regarding punitive measures, economic sanctions and armed interventions. This relates to the competing visions for Asia, examined in Chapter 3, as Japan's perceived role in Muslim Asia is influenced by the roles taken by other great powers, namely the U.S., but also China. To explore Japan's perceived role, and how punitive measures relate to it, role theory is applied. Role theory asserts that a state's behavior is determined by perceived expectations from both Self and Others. The practices that emanate from these 
expectations are honed through experience and social interactions. Here, the experience and social interactions are the cases of sanctions and interventions, which reveal a changing and refining of not only Japan's role, but also its norms and identity. In 1970, K.J. Holsti introduced role theory into foreign policy analysis. "Conventional terms such as 'great power' or 'middle power' do not necessarily indicate how much diplomatic influence states wield within any set of relationships" (1970: 242). Role theory is a means to break this down. Japan may be considered a great power or middle power, but this is exerted in ways differing from the U.S., or other powers. Role theory brings both agency and structural variables into consideration to explain foreign policy behavior. It is what Holsti called the national role conception:

A national role conception includes the policymakers' own definitions of the general kinds of decisions, commitments, rules and actions suitable to their state, and of the functions, if any. Their state should perform on a continuing basis in the international system or in subordinate regional system. It is their "image" of the appropriate orientations or functions of their state toward, or in, the external environment (1970: 245-46).

At the same time, "[n]ational role conceptions are also related to, or buttressed by, the role prescriptions coming from the external environment" (Holsti 1970, 246).

This chapter shows, however, that Japan's role regarding sanctions and interventions in Muslim Asia is in a state of flux between agency interests and structural influences that are evident in Idemitsu's statement. In other words, 'role expectations' are in a state of conflict between "domestic and/or individual expectations as to what the appropriate role is and what it implies," and the "implicit or explicit demands by others" (Harnisch 2011, 8). This chapter proceeds by examining cases of sanctions and interventions, but the two are treated separately. The chapter then concludes with 
thoughts on Japan's role, identity, and norms regarding sanctions and interventions, and how they relate to its values-based diplomacy.

\section{Sanctions}

Any analysis to Japan's approach on sanctions must consider Japan's own experiences as a sanctioned state, and the impact of this experience has on identity. For the U.S., narratives of World War II start with the Japanese attack on Pearl Harbor; for Japan, the Pacific War started with the U.S. embargo of crude oil exports. In September 1940, the U.S. banned all iron and scrap steel exports to Japan to demonstrate disapproval of its expansion into Asia, and in July 1941, all Japanese financial assets in the U.S. were frozen, effectively embargoing oil exports. The UK and Netherlands joined the embargo days later. If Japan was to "secure its capability to wage war, then it would inevitably have to risk - or make - war" (Yergin 1993, 319). As winter approached, the hardships of the embargo were felt in both the military and society.

At the Imperial Conference on 5 November 1941, Prime Minister Tōjō Hideki remarked: "The United States has from the beginning believed that Japan would give up because of economic pressure," concluding, "I fear that we would become a third-class nation after two or three years if we just sat tight" (Yergin 1993, 322). Tōjō's statement is revealing of identity and role, and the effect the embargo had on these. In the 2010s, a similar tenor is expressed in statements by Iranian Supreme Leader Ali Khamenei: "The purpose of sanctions and economic pressures is to prevent the developing efforts of the people of Iran" (2014). After the American withdrawal from the nuclear deal in 2018, Khamenei commented, "[w]e will never accept their bullying...[a]ny retreat by Iran will make America more blatant and impudent...Resistance is the only option" (2017). Both 
Japan of the early 1940s and Iran of the 2010s share an experience of American sanctioning to the point whereby inaction is impermissible. Japan chose war by deducing it was the only means for state survival; Iran has not. In the ongoing Iran case, however, Tokyo is very conscious of the decision it made when put in a similar position, and the outcome of that decision. Even in the postwar era, this historical experience must weigh heavily on policy decisions to join economic sanctions, particularly since it has been the U.S. - the same state who sanctioned Japan in the early 1940s with crippling embargoes - which is encouraging Japan to join in economic sanctions regimes today.

Japan experienced crippling sanctions by the West which were ultimately counterproductive in the sense that they contributed to the inevitability of war. This section continues with a review of two cases of sanctions carried out against states in Muslim Asia, and Japan's response to these sanctions. There is a consistency evident in Japanese thinking, that the decision to sanction a state can contrast with state security interests and the desire to be a model member of the international community. Moreover, it reveals a hierarchy of needs and values in foreign policy, which can change with time.

Japan does implement sanctions pursuant to UNSC resolutions, and also has cases whereby it has implemented unilateral sanctions. In 1990, Japan was the first state to sanction Iraq over its invasion of Kuwait, well before a UNSC resolution was passed. Japan has also joined the West in non-UN sanctions; it was the only Asian state to join the West in its sanctions regime against Russia after the 2014 invasion of Crimea. Japan has also resisted UN sanctions in the past, such as maintaining trade with and investments in South Africa during apartheid. It is also likely that Japan was prepared to violate a sanctions regime against the Taliban in 2000, when Japanese officials offered a proposal 
whereby they could protect the Buddhas of Bamyan statues in exchange for monetary compensation (Zaeef 2010, 127: Schmetzer 2001). ${ }^{1}$ Japan has experience with sanctions regimes from just about all angles, and this chapter argues that Japan's decision to sanction a state is based upon a hierarchy of needs and values, which are reflective in its perceived role of Self. This chapter looks at two key cases: the 1990s South Asia arms race, and the 2000s sanctions regime against Iran. In both of these cases, the development of nuclear weapons was the crux of the regime, which was of acute concern for Japan based upon its postwar values and identity.

\section{Sanctions and Non-Nuclear Norms}

\section{In 1967, Prime Minister Satō Eisaku announced the Three Non-Nuclear}

Principles. The principles committed Japan to nonproduction, non-possession, and nonintroduction of nuclear weapons into Japanese territory. The context of the principles was a more complex deal Satō made with U.S. President Richard Nixon: Tokyo would join the NPT at Washington's request (which it did in 1976), and in exchange, the U.S. would not place nuclear weapons at bases in Japan, and Okinawa would be restored to Japanese sovereignty (which it was in 1972, albeit with multiple American military bases remaining). The principles were passed as a resolution in 1971, which strengthened the norm behind the principles, but they were never codified into law. ${ }^{2}$ Satō clarified, however, that the Three Principles would not prevent Japan from developing peaceful nuclear energy technology, which already had been developing in Japan for two decades.

\footnotetext{
${ }^{1}$ If public, this might have been permitted by the sanctions regime, but it was conducted in a secret meeting, according to reports (Zaeef 2010, 127).

${ }^{2}$ For achieving the principles which strengthen Japan's normative commitment against nuclear proliferation, Satō received the Nobel Peace Prize in 1974.
} 
The nuclear non-proliferation norm is perhaps more than anything, one which Japan ardently champions internationally. The norm is unifying, and central to Japan's postwar identity and cultivated through narratives of historical experience. It is uniquely the only people to have experienced atomic bombings of their cities in warfare. Regardless of opinions of nuclear weapons in the twenty-first century, if there is any international norm which Japan is willing to champion and on which it takes a leadership role, it is bans on nuclear weapons. This is normativity seen at all levels, from political elites to grassroots. In Muslim Asia, this norm is notably shared in Southeast Asia and Central Asia - both regions have nuclear weapons moratorium treaties that declare the regions 'nuclear weapon free zones' as of 1997 and 2009, respectively. In bilateral meetings particularly between Japanese and Kazakhstani diplomats, reference is nearly always made that both countries share the experience of 'suffered harm from nuclear weapons,' and both use this in a way to shape the foundation of shared norms. The circumstances of how nuclear weapons were used in each case, however, are considerably different. For Kazakhstan, the experience was four decades of Soviet tests near Semipalatinsk, exposing locals to dangerous levels of radiation. The circumstances of the two cases were very different, and yet "Japan and Kazakhstan share a narrative that nuclear weapons were inhumanly used on their territories, by an external power, with disregard for the civilian population" (Barber 2018, 28).

For Japan, there are models of nuclear weapons-free regions in Muslim Asia, and norms can be shared on this basis. Many Muslims recognize the American use of nuclear weapons on Japan in 1945 as an act of dehumanization, and admire Japanese society for overcoming this experience. Miyata explains that "America's use of nuclear weapons is 
repeatedly emphasized in the Muslim Middle East because, postwar, it is seen with a striking resemblance to America's armed intervention in Iraq" (2014b: 222). For Japan, the narrative has never focused widely on the dehumanization aspect, in part, because postwar Japan largely entrusts the U.S. with its national security, and exists under the American 'nuclear umbrella.' The basis of the Japanese narrative regarding the nuclear bombings is more focused on the destructive force of the weapon, itself, and if Japan's narrative can perpetuate recognition of this norm by states in Muslim Asia to the point they commit to non-nuclear weapons regimes, this is satisfactory. Japanese are certainly not going to defend the American use of the weapon, but they also not going to join with narratives of dehumanizing behavior by the U.S. while under its nuclear deterrence umbrella. Concerns over nuclear weapons were exacerbated for Japan in 2016 and 2017 when North Korean increased its testing of nuclear weapons and of ICBM rockets which flew over Japan's territories. How does this strong norm interact with the cases of, firstly, the one nuclear-weapons state in Muslim Asia, Pakistan, and secondly, the ongoing global concern over Iran acquiring nuclear weapons?

\section{South Asian Nuclear Arms Race}

In 1965, Pakistani Minister of Foreign Affairs (and later Prime Minister) Zulfikar ali Bhutto famously declared: "The Christian, Jewish and Hindu civilizations have this capability [nuclear weapons]. The Communist powers also possess It [sic]. Only the Islamic civilization was without it, but that position was about to change" (Singh 1979, E21). Yet, after India detonated its first nuclear weapons test in 1974, Islamabad seemed to counter Bhutto's prediction by attempting several South Asian non-nuclearization regimes - all rejected by New Delhi. In the first decades of the postwar period, Japan 
kept diplomatic distance from both India and Pakistan. It was neutral in the 1965 war between the two, and found South Asia altogether too volatile for economic interests (Mathur 2012, 12). After India detonated its Smiling Buddha nuclear bomb tests in 1974, Japan reacted by forming together with Western states the Nuclear Suppliers Group to limit India's access to nuclear technology, equipment, and materials. By the end of the Cold War, Japan was warming to both India and Pakistan primarily through ODA. On 11 and 13 May 1998, India conducted its second series of tests. Pakistan responded by conducting its first public nuclear weapons tests on May 28 and 30.

The Japanese Diet immediately issued a resolution condemning the tests (Mathur 2012, 23). Within days, while member of the UN Security Council, Japan together with three other non-permanent members introduced Resolution 1172 to unanimously condemn India and Pakistan's tests. The Prime Minister ordered the Japanese ambassadors in New Delhi and Islamabad to return to Japan. These swift actions were mostly symbolic, but punitive actions were also carried out.

Together with the U.S. and Western states, Japan applied economic sanctions to both India and Pakistan, and cut off bilateral aid programs. All yen loans to Pakistan totaling \$231 million in 1997-98 were cancelled, as was all grant aid totaling \$55 million (Morrow and Carriere 1999, 5). Japan cancelled $\$ 1.2$ billion in yen loans to India, and $\$ 30$ million in grant aid. Japan's ODA cancellations were the most significant of any donor state (Morrow and Carriere 1999, 5). In the 1990s, Japan was the top source of ODA for both India and Pakistan, but the sanctions affected Pakistan more because of a much deeper dependency on ODA. On June 12, the G8 members unanimously declared 
they would collectively use their shares to oppose any non-humanitarian aid by the IMF, the World Bank, or the ADB to India and Pakistan (Morrow and Carriere 1999, 5).

There is evidence the sanctions had an impact. Kondō makes the observation:

Actually, economic sanctions were imposed on both countries and the elation after the tests was dissolved and interest in the weapons, themselves, was weakened. Thereby, the people's main concerns returned to economic and social problems, and soon, the people criticized their government for hastily carrying out tests without considering the possibility of an international reaction to sanction (2014: 187).

This is the strategy for the economic sanctions, but through carrying them out, it became evident that domestic destabilization was not the best outcome for even Japan's interests.

In one sense, Japan's actions after the May 1998 nuclear weapons tests were an expression of its normativity, but both Indian and Pakistani officials noted that it was not proportionate to Japan's response in previous cases. In 1996, China conducted a series of nuclear tests, yet Tokyo only temporarily froze scheduled grant aid to China, and not its yen loans (Mathur 2012, 24). Also in 1996, France conducted a series of tests in the South Pacific, which Japan was quick to condemn, but France was not sanctioned in the least. Officials in both New Delhi and Islamabad also pointed out hypocrisy of Japan moralizing the issue while existing under the American nuclear umbrella (Mathur 2012, 24).

Tokyo's conditions for loosening of sanctions were for India and Pakistan to abandon their nuclear weapons programs, and join NPT and CTBT: "India and Pakistan [must] not commence a dangerous nuclear arms race and conclude NPT and CTBT unconditionally" (MOFA 1998). Yet in the following three years, neither India nor Pakistan carried out further tests, but at the same time neither abandoned their nuclear 
weapons programs, or joined NPT or CTBT. By August 2000, Japan was already indicating it was considering an end to the sanctions on India (Mohan 2000, 1), and in August 2001 the U.S. was indicating the same, but both remained cautious about Pakistan following Pervez Musharraf's 1999 military coup (Perlez 2001). Musharraf's government was aware "the sanctions were fomenting a mood in both countries to support NPT via internal strife," and thereby formulated a strategy to loosen the sanctions without compromising on the nuclear weapons development (Kondō 2014, 187). Musharraf took measures to demonstrate that Islamabad could sufficiently manage the weapons, engaged in dialogues with Washington and New Delhi, and discussed joining CTBT, albeit, never committing. Counter to a dominant narrative, Islamabad was working towards removal of its sanctions prior to 9/11, and likely would have achieved this, as well as normalization of its nuclear arsenal. Just three days prior to 9/11, a source from the Japanese government leaked to the media the Cabinet of Prime Minister Koizumi Junichirō was seeking LDP approval to remove the sanctions on India, but still considering the sanctions on Pakistan (Hisane 2001).

Musharraf's strategy was working, but 9/11 was precisely what he needed to normalize his nuclear arsenal. The U.S. and Japan removed sanctions on both India and Pakistan within weeks after the attacks. In October, Japan's Chief Cabinet Secretary announced that Japan was simultaneously discontinuing sanctions on India and Pakistan:

both India and Pakistan have been maintaining their moratoria on further nuclear tests for the past three years and declaring their intention to maintain it. Furthermore, both countries have stated that they will ensure strict controls of nuclear and missile related goods and technologies. To that extent, Japan's measures have obtained due achievement (MOFA 2001). 
The objectives were undoubtedly watered down. The statement adds at the very end, "Japan will continuously urge India and Pakistan to make progress in the field of nuclear non-proliferation, including signing of the CTBT" (MOFA 2001).

The sanctions regime was framed as a victory precisely because nothing occurred. Rather, realistically the sanctions were destabilizing Pakistan, and thereby counterproductive to Japan's larger strategy. After ending sanctions on Pakistan, Japan's ODA was never restored to the pre-1998 levels: "Japan continued to bear in mind the security issue while restricting the fields of targeted aid to the societal sector, modernization of customs, and the economic sector" (Togawa and Tomomatsu 2011, 76). The exogenous circumstances of a new 'War on Terror' and the renewed geopolitical significance of Afghanistan allowed for a normalization of both India and Pakistan's nuclear weapons status, but it is significant to note that the U.S., Japan, and other states were already working toward ending the sanctions before the events on $9 / 11$. From the Japanese perspective, there was not a significant factor in this case to securitize Islam, although Islam was and still is an important factor for both India and Pakistan. Japan went to great efforts to condemn and sanction India and Pakistan equally for the tests. When war broke out between the two in 1999, Japan remained neutral. In fact, Islam is oddly among the factors why Washington wanted the sanctions against Pakistan removed; besides needing tactical access to Afghanistan, there was also the concern religious extremist elements of the Pakistan military and ISI would align with al Qaeda. Thus, removing the sanctions was to thwart the possibility of a religiously-based alliance. Over time, Pakistan's possession of nuclear weapons has become viewed both by the Japanese and globally as more problematic than India's possession, which has an 
Islamic aspect to it. The religious aspect increases the possibility that Pakistan's nuclear technology or weapons, themselves, proliferate outward from the regional security complex. With India, there has always been little concern over this. Yet, in a comparative case whereby Pakistan is interpreted as the Muslim state and India as the non-Muslim state, it is difficult to credibly argue the difference in gradual acceptance of their nuclear arsenals is securitizing Islam in Pakistan. There is also the instability of the government in Islamabad contrasting to a more stable New Delhi, the military junta ruling Pakistan versus a democratically-elected government in India, and Islamabad's proximity to and possibility of terrorist organizations acquiring, either by a consenting transaction or thievery, nuclear materials, technology, or weapons from the Pakistani military and ISI. All of these factors fog the conclusion that Islam is a factor. For the Japanese, this concern over Pakistan's nuclear arsenal manifested itself when Pakistani nuclear scientist, Abdul Qadeer Khan, confessed in 2004 that he provided the North Koreans with nuclear technology. The case does set precedents in several difference ways, as many in Japan would discuss this normalization process as the 'Pakistan model' - one which sets a perilous precedent in their view. Currently, Japan is fiercely resisting North Korea's progress toward nuclear normalization via the Pakistan model. Now, with Pakistan becoming a 'normalized' nuclear state, Japan's strategy is to support stability in Pakistan rather than sanction the government so that it will denuclearize. As well as the North Korea case, this has ramifications when considering developments in Iran.

\section{Iran Nuclear Program}

The U.S.-led sanctions regime against Iran had its start in November 1979 during the American Embassy hostage crisis. By January 1980, Washington was appealing to 
European allies and Tokyo to join to build a more effective regime against Iran, which would include sanctioning Iranian oil (Enayat 1994, 379). Tokyo refused the request, arguing that it was already a "hostage" with the amount of financial investments sunk into Iran while the revolution was taking place, but conceded that Japan would not increase oil purchases from Iran during the hostage crisis (Enayat 1994, 379).

The U.S. sanctions were removed when the hostages were released, but a second round of sanctions was applied in 1984 when the U.S. designated Iran a state sponsor of terrorism, and strengthened sanctions in 1987. In 1995, U.S. President Bill Clinton expanded the sanctions on Iran due to concerns over the nuclear program developments, banning American involvement in Iran's oil industry. The next year, the U.S. Congress passed the Iran-Libya Sanctions Act, which was key in flipping U.S. strategy on Iran from applying only primary sanctions to opening it up to include secondary sanctions, which compelled other countries to enforce the regime. American allies, such as Japan, were now discouraged from trading with Iran, else face the possibility of the U.S. penalizing their companies investing more than \$20 million annually in Iran's oil and natural gas. This round of sanctions, however, still did not have a significant impact on Japan. Most firms were able to continue operating in and with Iran, and oil imports from Iran continued to increase through the 1990s, but it did cause firms to refrain from additional investments in the oil and natural gas sector (Nukii 2014, 19).

This changed abruptly in the first years of the twenty first century. In 2002, a secret nuclear development program was discovered in Iran, and in 2005, Iranian President Mahmoud Ahmadinejad ordered the resumption of the uranium enrichment program (Nukii 2014, 19). In 2006, the U.S. froze assets of foreign entities suspected of 
assisting Iran. To implement this, an office was created in the U.S. Treasury Department with the ad hoc purpose of enforcing the sanctions rules. Despite Washington's warning not to do so, in 2004 Japanese oil firm INPEX commenced a joint-venture with the NIOC to develop the Azadegan oil field (Faiola and Linzer 2006, A14). With every drop of the estimated 36 billion barrels of oil from the Azadegan field expected to go to Japan, the field was enough to make up six percent of Japan's annual oil imports for years (Kafura 2016). U.S. sanctions were reinforced by UN Security Council resolutions 1747 in 2007, 1803 in 2008, and 1929 in 2010, and Japan's Diet passed measures to accompany all of these UN Security Council resolutions. In fact, Japan was sitting on the UN Security Council during Resolution 1929 in June 2010, and supported it. By 2010, both Japan and the EU were passing sanctions legislation on par with the U.S.'s sanctions. In doing so, their companies decided that the risks of doing business in Iran had begun to outweigh potential gains, and pulled out in increasing numbers. Japan responded by decreasing its reliance on Iranian oil by roughly ten percent annually. Between 2007 and 2012, Japan's oil imports from Iran dropped roughly 40 percent (Smith 2012).

In July 2010, the U.S. tightened its sanctions with the Comprehensive Iran Sanctions, Accountability, and Divestment Act (CISADA), prohibiting foreign entities from using American banks if they did business with Iran. Japan responded by passing its own legislation the next month banning new FDI projects, restricting financial transactions, and freezing assets of entities connected to the nuclear sector. Japan's sanction measures were an effort to dutifully show compliance with the U.S. and UN sanctions, but at the same time, exemptions were needed because Japan could not sever its dependency on Iranian oil so hastily. In 2003, Iranian oil made up 15.6 percent of 
Japan's total imports (Nukii 2014, 20), but this steadily declined to 9.7 percent in 2010, and 4.6 percent in 2015 (Japan Customs 2017).

These concerns only worsened in early 2011, when the Arab Spring and Great East Japan Earthquake exacerbated energy costs for Japan. In December, the U.S. enacted the National Defense Authorization Act (NDAA) to prevent foreign financial institutions from conducting business with Iran. The NDAA would be the most sweeping secondary sanctioning by the U.S. to discourage transaction with Iran by any third-party state, and resultantly, "drastically reduce Iranian oil imports to any principal country, including Japan" (Aoi 2015, 119). Despite exacerbating energy concerns, Japan, too, passed a new round of sanctions at the same time that would freeze the assets of entities linked to Iran (Kafura 2016). U.S. Secretary of State Clinton praised Japan's commitment to the sanctions, calling it "especially noteworthy" despite "extraordinary energy and other challenges" (Kafura 2016).

Yet, the sanctioning of oil was having a noticeable impact on Japan's economy. In March 2012, together with several EU nations, Japan appealed to the U.S. for sanctions exemptions for Iranian oil, based on a clear track record of compliance with the regime to that point. A U.S. State Department official referenced Japan as a compliant state in the secondary sanctions: "Japan was a model," adding, "[i]f Japan was able to do what it did...that should be an example to others that they could potentially do more" (Mohammed and Quinn 2012). Despite the exemptions and Japan serving as "a model," the existing sanctions were still too stringent for full compliance by Japanese firms. In December 2012, Bank of Tokyo-Mitsubishi UFJ was fined $\$ 8.6$ million by the U.S. Treasury Department for financing much of Japan's oil purchases from Iran (Nukii 2014, 
20). In June 2013, the bank received a staggering $\$ 250$ million fine by the New York State Department of Financial Services for the same violation (Nukii 2014, 20). ${ }^{3}$

In September 2013, Prime Minister Abe and President Hassan Rouhani met on the sidelines of the UN General Assembly in New York. MOFA summary notes on the meeting indicate that Abe told Rouhani, "I strongly expect Iran to dispel concerns of the international society and restore international confidence" (Abe 2013a). The use of transitive language, "[you] dispel concerns" placed the onus on Iran to act, but emphasized building trust without directly referencing the nuclear program. This expressed Abe's understanding that Iran had a responsibility to observe the obligations of full membership in the international society. Abe reportedly added, "a window of opportunity is not always open, and showing flexibility taking this occasion would be a key in order to solve the issue" (Abe 2013a). The "window of opportunity" Abe was likely alluding to was the P5+1 negotiations, which two months later arrived at an interim agreement. Just days prior to the interim Joint Plan of Action (JPA), ${ }^{4}$ Japanese Foreign Minister Kishida visited Tehran, where he urged Rouhani and Foreign Minister Mohammad Javad Zarif to ratify CTBT, and according to Kishida's own account after his return to Tokyo, he "worked with the Iranians on some specific proposals" which were worked into the P5+1 summit (Kishida 2013b). He added, "our country is working from a unique position" regarding the negotiations, aiming for "consensus building" (Kishida 2013b).

\footnotetext{
${ }^{3}$ U.S. states, such as New York, were also applying secondary sanctions against foreign entities for conducting business with Iran.

${ }^{4}$ According to JPA, Japan as well as China, India, South Korea, Taiwan, and Turkey were allowed to resume purchases of Iranian oil from January 2014 until July 2015.
} 
Considering the "unique position," Japan's absence from the P5+1 negotiations is noteworthy. P5+1 was preceded by negotiations that started in 2003 between Iran and the EU3 (UK, France, and Germany). These were opened up in 2006 to include the U.S., China, and Russia. At that time, Japan was Iran's third largest trading partner and by a long stretch its largest consumer of oil, at 22 percent of Iran's export that year (Faiola and Linzer 2006, A14). Japan's Arc foreign policy was just in formulation, Tokyo was already engaging with Tehran via the bilateral human rights dialogue for a number of years, and, of course, it had a deep interest in nuclear non-proliferation in Asia. It was member of the Six-Party Talks regarding nuclear weapons development in North Korea, and together with Germany, India, and Brazil, advocating for inclusion as permanent members to the UN Security Council. Yet, while even Italy was invited to the P5+1 talks and briefly joined the negotiations in 2006 and 2007, Japan never was.

When the talks started in 2006, Japanese leaders complained about being left out, despite "being asked to make the largest potential sacrifice" (Faiola and Linzer 2006, A14). Other Japanese officials optimistically suggested it provided them the opportunity to operate outside the framework of P5+1 agreements. Yoshimura argues Japan had a unique role to inform Iran of the risks of nuclear development, thinking beyond just concerns over weapons development:

There are military great powers and economically developed states which compose the models for developing countries. Such existing thinking must be questioned from its core, whether militarily or economically, and we [Japan] can warn through the lessons of Hiroshima, Nagasaki, and Fukushima that the source of great power status, or a developed country's power has become fixated on poor examples (2014: 226). 
Indeed, this is an applicable perspective none of the nuclear weapon-holding P5 members could provide. Miyata suggests the other members discounted the need for Japan to join on account of its postwar security dependency on the U.S.: "It seems the reason Japan could not participate in the nuclear negotiations was expressed in the lack of trust of a Japanese foreign policy that only emphasizes its alliance with the U.S.” (2015: 274). This might explain why others did not see a need for Japan to join, but what about the U.S. itself? Oddly, this question has rarely been raised.

The sanctions would have never achieved such an economic crippling affect since 2006 if it were not for Japan's reluctant acquiescence, and reluctant acquiescence is precisely how to describe Japan's role in the sanctions regime. In June 2006, Abe was serving as the Chief Cabinet Secretary for former Prime Minister Koizumi. Abe expressed doubt at the time about the possibility of sanctions on Iran: "It might not damage Iran, but could cause confusion in the world economy" (Abe 2006). The same week, as foreign minister, Asō clarified that it was premature for Japan to consider sanctions against Iran (Preble 2006). This is Japan weighing the hierarchy of needs and values in its foreign policy, namely non-nuclearization, alliance with Washington, energy dependency, and its own sanctioned experience.

Tokyo's reluctance to support U.S.-led sanctions should not be misconstrued, however, as lack of interest in Iran's nuclear developments. Japan was deeply concerned; again, the concern sprang from the core of its postwar identity. In a 2010 Pew Research Survey, 75 percent of Japanese respondents expressed a negative view of Iran, which was higher than any other Asian state where the survey took place, and even higher than American respondents at 67 percent (Pew 2010, 43). In the same survey, Japanese 
opposition to Iran acquiring nuclear weapons was at 96 percent - the second-most unanimous view in the world (to Germany at 98 percent) (Pew 2010, 45). Japan had sincere concerns over nuclear technology sharing between Iran and Syria, and more pertinently, North Korea. Unequivocally, Tokyo distrusted Tehran's intentions with its nuclear program, and did want a solution, but reluctant acquiescence to economic sanctions was tolerated as the bigger power's strategy. Thus, carrying out its role took a backseat to the strategy of Japan's main ally to a certain extent.

When Tokyo acquiesced to the sanctions regime and reduced its oil imports, product exports, FDI, and financial services linked to Iran, much of that vacuum was filled by traditional rival, China, and, to a lesser degree, by South Korea and India, which had paid less heed to U.S. sanction regimes (see Table 8.1). Indeed, INPEX's 75 percent share in the Azadegan project gradually whittled down to ten percent, and INPEX eventually pulled out of the project altogether in 2010, only to be replaced by China National Petroleum Corporation (CNPC) (Kafura 2016). ${ }^{5}$ Japan seemed to only be hurting itself by complying with the sanctions. Secondly, there is also a more pragmatic explanation for Japan's softer position on Iran: government-owned Japan Bank for International Cooperation had roughly $\$ 3.7$ billion in existing loans to Iran (Nukii 2014, 20). If significant friction between Japan and Iran were to develop, Japan would risk never receiving repayments.

Thus, notwithstanding the threat of nuclear proliferation which was an earnest concern for the Japanese, another threat emerged in the sanctions regimes in Japan's

\footnotetext{
${ }^{5}$ CNPC was dismissed from the Azadegan field in 2014 after Tehran complained the development was moving too slowly (Kafura 2016).
} 
perception: the American threat that amplified the risk of conducting business in Iran, which already existed. Thus, secondary sanctioning was Washington threatening close allies, like Tokyo. As progress was being made in the P5+1 negotiations with Iran, "[i]n Japan, business interest in Iran after the lifting of sanctions is high, and the attraction of lectures relating to Iran is high, so corporations are conducting their own in-house seminars" (Murakami 2014, 44). One such seminar was given in 2015 by Security and Trade Management Advisor for Mitsui, Aoi Tamotsu, who later used his lecture on business in Iran for the basis of an article:

At present, it is necessary to be overall watchful while cautiously moving forward. By 'overall watchful,' that is Japan-U.S.-Iran; I mean be always cognizant of Japan's triangular relationship. When Japanese firms make business connections with Iran, consider U.S. relations, meaning it is necessary to sufficiently ascertain [italics added] whether this transaction will be within the range of lifted sanctions. Also, it is necessary to always be cognizant that considering Iran and U.S. relations, depending on the circumstances there will be the possibility that sanctions are reinstated (2015: 128).

A similar conclusion was reached by Middle East scholar Murakami Takuya: "Because Japan has the bitter experience of not being able to prevent the loss of development rights at the Azadegan oil field due to American pressure at the time, Japan must be cautious when ascertaining [italics added] the shift in nuclear negotiations" (Murakami 2014, 44).

Both Aoi and Murakami's opinions used two of the same words: "caution" (shinchō) and "ascertain" (mikiwameru). Clear from this interpretation is that the sanctions regime was a threat to business interests. Moreover, the position of the Japanese government as a sanctioning agent was not even addressed. Firms perceived a threat from Washington before one from their own government in Tokyo. If sanctions were to be reinstated, the question of whether or not Tokyo supported them was not even 
of concern. Rather, businesses have to be wary because of American actions, and indeed, this threat has manifested itself. In May 2018, U.S. President Trump announced the U.S. would withdraw from the P5+1 agreement. Both Foreign Minister Kōno and Chief Cabinet Secretary Suga Yoshihide described the decision using the same word: "zannen" ('a pity').

\section{Interventions}

The contemporary non-interventionist norm in Japan is naturally based upon the experiences of war, but this, alone, is not enough to form the basis of this noninterventionist norm. Rather, the norm was cultivated and reinforced through postwar institutional arrangements. Article IX, as a renunciation of war, is the most eminent part of Japan's Constitution: “Aspiring sincerely to an international peace based on justice and order, the Japanese people forever renounce war as a sovereign right of the nation and the threat or use of force as means of settling international disputes." It adds, "land, sea, and air forces, as well as other war potential, will never be maintained."

The norm was still not institutionally embedded in Japan's identity and role in Asia in 1947. Japanese soldiers in Vietnam and Indonesia who never repatriated after the Second World War were concurrently joining independence movements in those countries. While MacArthur ordered that Japanese would not be permitted to fight with the U.S. in Korea, many Japanese young men, unemployed and with battlefield experience, are known to have joined U.S. military units traveling from bases in Japan to Korea (Morris-Suzuki 2012, 2). Also, during both the Korean and the Vietnam wars, Japan sold large amounts of materiel to the U.S. military, including napalm. These acts were done discreetly, but illustrate that in the years immediately after the Peace 
Constitution, Japan was already taking a malleable approach to this norm, and it was hardly developed.

In 1954, the Police Reserve was renamed the Japan Self Defense Force (SDF) and acquired the new charge of defending the country from external threats in a supporting role to the U.S. forces in Japan. SDF troops are civilians, and yet the institution is by all accounts a modern military with Air, Marine, and Ground SDF branches, but deliberately avoids using the term 'military' to attempt adherence to Article IX. It was an arrangement of which both Tokyo and Washington approved at the time, and takes advantage of a loophole which allows the norm to persist.

By the late 1960s, the non-militarization norm was strengthening. In 1967, to accompany the aforementioned Three Non-Nuclear Principles, another 'Three Principles' were passed by the Diet: Three Principles on Arms Exports. The principles would prevent the export of arms to: (1) communist bloc countries; (2) countries under arms exports embargo by the UN Security Council; and (3) countries involved or likely to be involved in international conflicts. In 1976, the restrictions were tightened to a ban on all arms exports, save some technology transfers between the SDF and the U.S. military. In the same year, Japan self-imposed a restriction on defense spending of no more than one percent of its annual GDP. This allowed it to grow, but relative to the nation's wealth. The rule did much to shape Japan's role and identity by allowing a quantifiable appearance of constraint for observers both domestic and international, but in reality the defense budget of the late 1970s was already eighth largest in the world, and by the end 
of the 1980s Japan's defense budget was third only to Cold War rivals the U.S. and USSR (LaFeber 1997, 372). ${ }^{6}$

The norm was further codified in Japanese foreign policy by Prime Minister Fukuda Takeo in 1977, when he announced the 'Fukuda Doctrine' for Southeast Asia while in the Philippines. Just four years after the U.S. withdrawal from Vietnam, it spelled out for Washington, Beijing, and all Southeast Asians how Japan intended to interact with the region. The first principle of the Fukuda Doctrine is most germane: “Japan, a nation committed to peace, rejects the role of a military power." Fukuda did deem it necessary to mention Japan had the capability to remilitarize and produce nuclear weapons, yet each would be in violation of Article IX. There were geopolitical ramifications, as it was perceived as Japan filling a void left by the U.S. withdrawal from Vietnam, and strengthening relations with ASEAN as a counter to both the Soviet Union and China, and an insurance policy in light of declining U.S. hegemony. Yet, the emphasis on exerting power politics with a pledge to non-militarization was baffling, but acceptable to many in Southeast Asia. It was also a reaffirmation of the Yoshida Doctrine, since the second and third principles were carried mostly through geoeconomic facets, but paradoxically, they were intended to surpass direct material interests in Southeast Asia, and fix a shared geoculture. As far as greater Muslim Asia is concerned, Southeast Asia serves as the gate for twenty-first century policy predicated on an Asian geoculture.

\footnotetext{
${ }^{6}$ In the mid-1980s, amid much public debate, Prime Minister Nakasone Yasuhiro called for abandoning the principle, and his cabinet decreed such in 1987, yet defense spending only occasionally surpassed one percent of annual GDP less than a hundredth of a percentage point in the late 1980s. Thus, all that was really achieved was rounding down to one-percent.
} 
The Yoshida Doctrine, the Fukuda Doctrine, and further principles and rules allowed Japan a strategy to “'depoliticize' Asia," preserve Article IX of its Constitution and strengthen its normative position, and actually follow through with its commitment while ensuring its own national security (Miyagi 2018, 122). National security was largely delegated to the U.S., and Japan's engagement with the world would foremost be driven by economic interests. These doctrines and principles saved Article IX. Japan has no primordial predisposition to noninterventionism or pacifism, and the experiences of World War II would not be enough to have constructed such a robust norm, but the Yoshida Doctrine facilitated it. In turn, however, the doctrines and principles would never have been possible without Cold War geopolitics. For Japan, however, the end of Cold War order came abruptly with the Gulf War in 1990.

\section{Gulf War and Gulf Trauma}

Since the 1980s, the U.S. has repeatedly pressured Japan to break its one-percentof-GDP restriction on defense spending, and take up a larger role in collective security in Asia, which is an astonishing transformation given the role U.S. advisors had in crafting Article IX of Japan's Constitution. In August 1990, Iraq invaded Kuwait. At the time, Japan was the single largest importer of Kuwaiti oil, purchasing 0.4 of the total 1.8 million barrels per day exports in the first half of 1990 (CIA 1990, 8) (See Table 8.2). Japan was also the single largest importer of Persian Gulf oil, accounting for over a third of OECD imports from the Gulf (CIA 1990, 6). The U.S. quickly formed a broad coalition to intervene, yet Japan was not part of it. When U.S. President George H. W. Bush requested from Japanese Prime Minister Kaifu Toshiki assistance in transport and supply to the Persian Gulf, Kaifu refused based on Japan's constitutional constraints. The 
U.S. Congress adopted a resolution criticizing Japan for its lack of support, and ranking House Democrat Richard Gephardt even notified Kaifu that the U.S. would practice import restraints on Japanese automobiles if Tokyo failed to make a meaningful contribution to the Gulf War (Catalinac 2007, 67). Tokyo initially announced a $\$ 1$ billion contribution to support the multinational force, which in time, rose to nearly $\$ 13$ billion nearly a quarter of the total cost of the war (Fuse 2015, 34). Yet, Japan hardly received any credit for its contribution to the war. When the Kuwaiti government penned a fullpage message of appreciation to the coalition in the New York Times, there was no mention of Japan.

While the U.S. was heavily dependent on Iraq as a key Gulf supplier and Western Europe on Iran, Tokyo deliberately developed strategic relationships with the wealthy, small Gulf emirates like UAE, Qatar, and Kuwait rather than depend on volatile, war-torn states like Iran and Iraq (CIA 1990, 6). Thus, insofar as the Gulf War was a war over oil, Japan had much more at stake from Saddam Hussein's invasion of Kuwait than any other consumer state. Yet, where was it among the coalition to liberate Kuwait? The financial assistance Tokyo offered was crucial for the war effort, but both the Kuwaitis and coalition partners noted there were no Japanese boots on the ground. Still under pressure by Washington to contribute, in April 1991, two months after fighting had stopped, Tokyo finally allowed for limited support by dispatching Marine SDF for minesweeping in the Persian Gulf. Although this was a major step as the first ever SDF deployment abroad, and, indeed, they successfully cleared 34 mines, it did very little to shake the negative reputation (Middlebrooks 2008, 39). 
The end of the Cold War was a critical juncture in Japan's security policy, but the realization that this critical juncture had arrived did not really set in with the political leaders until the Gulf War. The norm of non-militarization had strengthened from the 1947 Peace Constitution to the 1977 Fukuda Doctrine. It was a source of identity and pride for Japanese in that their nation is a uniquely peaceful great power. Yet, in light of events in the Persian Gulf War, Japan was seen as a freeloader, getting its massive supply of oil secured by others, motivated only by economic interests, and unwilling to cooperate with an international coalition. The concern over obligation to an international coalition as Japanese echoes the aforementioned statement by Idemitsu in 1953. International normative obligations contrasted with state normative obligations which were reinforced through self-constraining rules and laws. In Japan, the condition became known as 'Gulf Trauma.' The financial contribution to the war effort was defined as 'checkbook diplomacy,' but uttered only in disdain. A quintessential shame culture as identified by Ruth Benedict (1946) was compelled to respond in order to resuscitate its reputation among its peers, thus saving face.

From the experience of Gulf Trauma, Japanese were compelled to reevaluate their role in the international society - a reevaluation that is still not settled. Changes of roles come about in two ways: adaptations and learning. Gulf Trauma was the latter, and more specifically, it was a case of complex learning, because it demonstrated "changes in the actors' own preference ranking or a transformation of the underlying understanding about the nature of the political system within which the actor functions" (Harnisch 2011, 10). In June 1992, the Diet passed the International Peace Cooperation Law, which would allow for a very restricted use of the SDF in overseas UN peacekeeping operations. SDF 
dispatches were to be limited to operations under a unified UN command, and necessitated a UN Security Council resolution before Japan could participate. Moreover, the recipient country must be in concurrence according to the Law. The conditions were designed to be deliberately restricting, but that year the first peacekeeping deployment of SDF was sent to Cambodia under a UN flag. In the 1990s, various peacekeeping dispatches of SDF took place across Asia and Africa, including a transport logistics unit for the UN Disengagement Observer Force in Golan Heights in 1996 (see Table 8.3).

In 1993, veteran politician Ozawa Ichirō, who was LDP Secretary General during the Gulf War and was one who endured much of the American pressure, broke away from the LDP, and called for sweeping reforms so that Japan could become a "normal nation" (futsū no kuni). Ozawa expressed that it was time for Japan to shed postwar security arrangements, and make a more proactive contribution to the international society. The recent experiences in the Persian Gulf War prompted a question at home: is Japan a 'normal nation?' Is it time for Japan to become one? Increasingly, the view that was once limited to the fringe far-right that Article IX of the constitution must be amended was becoming more mainstream. Ozawa was not member to this camp, but his notion of 'normal nation' was the bridge to wider discussions on Article IX, Japan's contribution in collective security operations overseas, and identity and role.

\section{War on Terror}

The attacks on the U.S. on 11 September 2001, sparked new debate in Japan about further widening the use of SDF overseas beyond just UN peacekeeping missions, and now including collective security actions together with its ally, the U.S. This was a means to mend the mistakes that caused Gulf Trauma a decade earlier. Within weeks 
after 9/11, the Diet passed the Anti-Terrorism Special Measures Law, whereby the SDF could cooperate with allies on foreign soil or on high seas in support activities, in noncombatant zones, and without necessitating a centralized UN command or a UN Security Council resolution. The Law legally defined Japan's actions overseas in terms of selfdefense. While opposition parties objected, domestic support for the bill was wide (Sato 2008, 96). In 2001 Prime Minister Koizumi initially envisioned dispatching Ground SDF into Afghanistan together with NATO, and making a contribution on par with Britain or Canada, but as the war progressed, without the proper legislation passed this sort of Ground SDF operation became less likely. Nonetheless, Japan supported the war by providing fuel for coalition vessels in the Indian Ocean. The operation continued until January 2010 when new DPJ Prime Minister Hatoyama Yukio let the law expire over concerns of unconstitutionality. Between 2001 and 2012, Japan offered \$7 billion to support the war in Afghanistan, which made it the second-largest financier to the U.S. (Tuke 2013).

Like Afghanistan, Prime Minister Koizumi was quick to express support for the U.S. in the Iraq invasion in 2003 due to lessons learned from Gulf Trauma, but policy changes which would reshape the non-intervention norm were necessary for Japan to carry through with its commitment. In July, the Diet allowed for SDF participation through humanitarian assistance, postwar reconstruction, and domestic security by passing the Iraq Reconstruction Support Law, with the support of the LDP, New Komeito, and opposition DPJ. This would be the first overseas dispatch of the SDF in a non-UN peacekeeping operation. After a UN Security Resolution was approved in October for reconstruction in Iraq, in December a plan was drawn up to send roughly 
1,000 Ground SDF troops to southern Iraq for non-combat operations, although the government had difficulty convincing opposition parties and the public that it truly was a 'noncombat zone' (Catalinac 2007, 66). The Marine SDF operated off the coasts of Oman and Yemen, refueling nearly a thousand ships during its 14-month deployment (Smith 2014, 13).

Many observers link Japan's commitment to the wars in Afghanistan and Iraq to the development of a nuclear weapons program in North Korea. Tokyo had to demonstrate commitment to Washington's interests in order to receive support over security concerns in Northeast Asia. The link between North Korea and the Middle East was solidified with its inclusion in the Axil of Evil. From Tokyo's perspective, that is evidence Washington had linked North Korea with Iraq and Iran. Catalinac, however, raises a pertinent question to counter this argument:

If Japan was motivated to support the United States in Iraq because of the threat of North Korea, why did it not do more? Why did it not pass the legislation earlier and commit troops to the actual invasion? In the end, Japan's response was not exactly a strong show of force (2007: 70).

While plausible, Japan committed to both of these wars before earnest progress was made in North Korea's weapons program. Moreover, once North Korea's ICBM tests presented a viable threat to the U.S. mainland, Tokyo and Washington were easily in a consensus on defining North Korea as a security threat. Japan's commitment to the U.S.-led wars was more about Gulf Trauma than North Korea, securitization of Islam, or anything else. It was the risk of being left behind. 


\section{Counterpiracy in the Gulf of Aden}

Japan's involvement in the wars in Afghanistan and Iraq met some controversy at home, but the largest non-humanitarian SDF deployment has been in the Gulf of Aden since March 2009. Located between Yemen and the Horn of Africa, the Gulf of Aden is a strategically significant stretch of water between Asia and Africa for global shipping routes. The 21,000 ships that annually cross the Mediterranean Sea and Suez Canal en route to Asia and the Pacific must pass through the Gulf of Aden (Teo 2015, 175). The War on Terror, alliance with Washington, and economic interests as well brought Tokyo to consider acting on the piracy issue in the Gulf of Aden. Once the mission started, however, it became framed less as counterterrorism and more as a counterpiracy mission based on 'rule of law,' and free and open seas.

After UN Security Resolution 1816 was passed in June 2008 to authorize countries concerned to enter Somalia's territorial waters and apply "all necessary means" to prevent piracy, the Diet passed the Anti-Piracy Law the following month. At the time, Asō was Prime Minister, and was key in pushing through the legislation. When a DPJ lawmaker argued in October 2008 that Tokyo should support counterpiracy measures in the Gulf of Aden, Asō quipped, "[t]o be frank, that is like something an LDP member would suggest" (Shugiin 2008). With the Anti-Piracy Law, the Marine SDF is allowed to escort foreign commercial ships, rather than just Japanese-owned freighters. Also, the Marine SDF is allowed to engage pirate vessels if warning signals are ignored. A very broad coalition that included NATO members, but also China, India, Pakistan, and even Iran was dispatched to the Gulf of Aden (Teo 2015, 183). In June 2011, for the first time Japan leased an overseas SDF base. The new base in Djibouti would facilitate the 
counterpiracy operation, and also serve as a base for operations to evacuate Japanese nationals in Africa and the Middle East, if needed. ${ }^{7}$ The timing of the base project is surprising, considering that the center-left DPJ, which was in power at the time, carried through with the decision to lease, and build the base. Moreover, it was built at a cost of 4.7 billion yen, and completed just three months after Japan experienced the most expensive natural disaster in world history to date.

Taking part in the counterpiracy coalition was significant for carrying out Japan's role and strategy in several regards. It demonstrated Japan in the role of a "normal nation,' it allowed for an effective defense partnership between Japan and the U.S., where Japan could stand on a more equal footing. Similarly, it gave Japan's SDF the opportunity to take part in a broader coalition of states. It also transformed Japan's role as a guardian of sea-lanes far afield, near the Middle East. Lastly, it garnered wide support from both LDP and opposition parties in Japan. It served as a clear illustration in the shifting of norms in Japan, since the DPJ, which tended to represent the center-left opposition to SDF engagement in overseas peacekeeping operations in the early 1990s, was now together with the LDP in supporting use of the Marine SDF in a counterpiracy coalition as well as placing a SDF base overseas. The coalition has been successful in decreasing cases of Somali piracy since 2012 and in November 2016 NATO ended its Operation Ocean Shield mission, but the Yemeni civil war is causing many coalition states, including Japan, to retain forces in the Gulf of Aden, mainly over concerns of shipping disruptions.

\footnotetext{
${ }^{7}$ The base was first used for civilian evacuations from South Sudan in July 2016.
} 


\section{Abe's Defense Reforms}

Since returning to the office of Prime Minister in December 2012, Abe has been more effective than any of his LDP predecessors in carrying out defense reforms which revised the norm. First, in April 2014 he overturned the 1976 total arms exports ban as well as the 1967 Three Principles on Arms Exports. These were replaced with the 'Three Principles of Defense Equipment Transfers,' whereby all arms exports are permitted if approved by the newly created National Security Council, and (1) prohibited in cases where the transfer violates international treaties to which Japan is party, obligations under UN Security Council resolutions, or a country party to a conflict; (2) permitted only in cases whereby the transfer contributes to promoting peace and international cooperation, and Japan's security; (3) prohibited from allowing extra-purpose use and transfers to third parties. The first arms export under the new Principles took place in July 2014 when Mitsubishi Heavy Industries sold components of PAC-2 missiles to the U.S. for export to Qatar. Japan has already pitched direct arms sales to several countries including Turkey, India, and Australia, but to date the only successful transfers have been donations of patrol vessels to the Philippines and Vietnam. Its two biggest arms manufacturers, Kawasaki Heavy Industries and Mitsubishi Heavy Industries are both known for civilian products, and their defense products have the disadvantage of not having been widely tested on the battlefield.

Second, In March 2017 Abe stated that the defense budget cap of one-percent-ofGDP would be abolished. ${ }^{8}$ Abe's declaration was purely symbolic, since there is no legal

\footnotetext{
${ }^{8}$ As previously mentioned, Prime Minister Nakasone's cabinet already decreed abandoning the principle in 1987, yet since then defense spending has only occasionally surpassed one percent of the annual GDP and
} 
basis for retaining the principle; it exists only as a norm, so therefore, Abe's statement was an effort to challenge this norm. Since then, there have been notable increases in the fiscal 2017 and 2018 defense budgets, yet neither surpassed one percent of GDP.

Thirdly, Abe's most ambitious revision has been to transform Article IX in some form to accommodate collective security actions with allies. When Abe returned to the office of prime minister in December 2012, he expressed the intent of pressing for a constitutional amendment to replace Article IX. This idea was met with wide resistance among the public, in the Diet, and among LDP party members, so Abe's Cabinet compromised this objective in July 2014 by 'reinterpreting' the language in Article IX to allow for collective self-defense. The decision received much international attention, as it was condemned by China, but supported by the U.S., Philippines, and Indonesia. The reinterpretation of Article IX was codified in September 2015 by a series of bills in the Diet that would allow the use of SDF to defend allies overseas. While campaigning for support for the bill in February, Abe used the recent case of ISIS beheading two Japanese nationals in Syria as a reason why Japan must have this legislation by pointing out that Japan failed to act during the hostage crisis due to "restrictions on its purely defensive armed forces," which could not "conduct rescue missions, evacuations and other overseas operations to protect Japanese nationals" (Fackler 2015, A9). While the constraints on action Abe noted were true, they hardly related to acts of collective self-defense and defending an ally overseas, which was the crux of the legislation.

by no more than less than a hundredth of a percent. Abe's intention was to create even more normative flexibility than the minuscule amount Nakasone achieved. 
Since returning to office and pursuing legislation to allow SDF participation in collective self-defense, Abe has also revived the nebulous idea of an 'NATO of Asia' together with the U.S., Australia, and India. The idea of deepening security relations with these states was first pursued during the Koizumi administration. In December 2006, the Deputy Press Secretary Taniguchi Tomohiko made the statement, "there is ample room for Australia, Japan, the U.S., and India to work closely together, because these four nations are very much concerned about the peace and stability over the sea lanes that is a vital link between this part of the world and the Persian Gulf region" (2006). When Abe served his first term as prime minister in 2007 , the four parties met just once as the Quadrilateral Security Dialogue, or 'the Quad.' In November 2017, it was revived with a second meeting. Abe has been an active supporter of the Quad, but with a deep economic dependence on Beijing for development of its resource sectors, Australia has expressed concerns over isolating China, and India has expressed concerns over tightening relations with the U.S. Abe's goal is to put Japan on a more equal footing, as a 'normal nation' in a collective security alliance with close democratic allies, just like NATO, and building its leadership role in Asia.

Obviously, the shared securitized threat is China when one considers the language used on 'free and open seas' as well as an ongoing emphasis on the member states as democracies. In fact, in his December 2012 English-language column in Project Syndicate, Abe called the alliance proposal, "Asia's Democratic Security Diamond" (2012). If made into a viable security alliance, unlike NATO, it would significantly transverse civilizations and expand to a very large maritime scope. By emphasizing that the four states are democracies, and in fact, have little else in common, it is predicating 
itself on democratic peace theory - that democracies will always choose to forego war with each other, and working together, can take on the responsibility of stabilizing the region. Yet, at the same time, it appears as if democracy is simply the common denominator that the four states share, and China does not.

What does the Quad mean for Islam? Using 2018 numbers, the combined defense spending of the four Quad members is $\$ 764.3$ billion, which is less than the combined defense spending of the 29 NATO members, at $\$ 957$ billion, but is still a substantial combined defense budget, nonetheless. Therein lies, however, the risk. If, for example, the U.S. experiences a large-scale terrorist attack, and in retaliation calls on its Quad allies to defend it under collective self-defense, Tokyo would be obliged to do so. What if the attackers originated from Syria, well beyond the geographic scope of the alliance? Moreover, it risks bringing Russia into conflict. Or, what if Washington called on the Quad to support securing a threat to Israel? What if conflict breaks out in Kashmir? Or, there is a Pakistan-linked bombing in an Indian city? These are scenarios where Japanese really do not want to respond. None of these four states are Muslim-majority states, and while India does have a substantially large Muslim-minority population, the wide civilizational framing of the Quad as an alliance among two non-European Western states, a Hindu civilization, a Japanese civilization could contort into a wider dichotomy of the Muslim world versus the rest, and not just the West. It also raises a prescriptive question: Should the Quad include Indonesia or Malaysia? Assuming the Quad defies odds and develops into a full alliance, this would be an important addition to both reassure it will not present a threat to Muslims, and also carry out the stated objective of protecting sea lanes, with the most crucial chokepoint at the Straits of Malacca. Neither 
state would have much to provide in terms of military power and are still young in the process of democratization, but the symbolic and strategic inclusion would be valuable.

Yet, in asking this question regarding the Quad and Islam, one could retort with a similar question: What has NATO meant for Islam? In this case, too, Islam was not the threat to be securitized which justified the creation of the alliance. And yet, most NATO interventions have taken place in Muslim countries. Moreover, consider the proclivities of the other Quad members. Australia would gladly shift focus from China to elsewhere. The U.S. has consistently prodded Tokyo to be proactive in its coalitions. India's primary perceived threat since the 1947 partition has been Pakistan. Assuming the Quad develops, any one of these three partners could easily turn this collective security alliance into an institution to securitize Islam, and with an armed alliance to support it.

\section{Conclusion}

The preface to the Japanese Constitution reads: "We desire to occupy an honored place in an international society striving for the preservation of peace." The meaning of this statement - Japan as peaceful - has not changed. Yet, this leads today to a question: How do you occupy the place? Moreover, how do this in dealing with Islam? Punitive measures were not emphasized in the Arc as presented by Asō in 2006, but he did mention at the time,

since the end of the war, Japan has been making achievements in pacifism, such that no one can possibly point a contemptuous finger at Japan. Find for me even one other country that has an organization like Japan's Self-Defense Forces, that for 60 years has shot not a single round of artillery, nor a single bullet from a gun (2006).

Can this obvious source of pride, and essence of national identity be maintained? 
From the Yoshida Doctrine to the Abe Doctrine

The incremental motions of revising/weakening Japan's non-interventionist norm, which really started with Prime Minister Nakasone Yasuhiro in the 1980s, but have been manifest most evidently with Abe since 2012 are reflective of a realist worldview, as was the Yoshida Doctrine, the Fukuda Doctrine, and constraining principles. Yet, it says a lot more about the changing dynamics of international politics across Asia and less about Japan's view of Islam as an imperiling force which must be securitized. Seeking 'normal nation' status through strengthening self-defensive capabilities is a view held not only by hawkish political elites, but also a significant segment of society, and opposition political parties. On the other hand, a comparably large segment of society is still adamantly opposed to these measures on the basis of Japan's values, norms, and identity.

Hirata Keiko has a typology of four role conceptions in Japan based on ideological predispositions: the mercantilists, normalists, pacifists, and nationalists (2016: 58). While a useful framework, it is based primarily on security dynamics in Northeast Asia and thus, says nothing about the securitization of Islam in the twenty-first century. To conclude, this chapter builds on Hirata's role conceptions to construct a typology as it relates to securitization of Islam (see Table 8.4). There are three camps in Japan regarding interventions in Muslim Asia. Like Hirata's types, individuals may move back and forth between types based on behavior.

Firstly, there are those whose ideology is Japan as Pacifist. They reject interventions altogether as a form of neo-imperialism, characteristic of the Western powers, counterproductive as strategy, perhaps share a view of Asianist solidarity with Muslims, and thus do not view it as permissible by Japan, let alone the West. Among 
political leaders, this view is mostly limited to the Japanese Communist Party and Social Democratic Party. Japanese scholars of Islam and the Middle East, however, are widely in this camp, primarily based on the concern of the image that Japan could potentially attain as an armed American ally. Yamamoto Takehiko writes on Japan's progress towards collective self-defense:

It is not impossible to think that in the eyes of Islamic fundamentalist groups such as ISIS, such measures would reflect as a declaration of intention to be an unwavering member of an anti-Islamic coalition to which the U.S. plays a central part. If this happens, they will increasingly see Japan as hostile, and even in logistical support, Japan's dispatched SDF support units could be included among their attack targets (2015: 62).

Miyata argues "I look at an American foreign policy with the Middle East which made terrorism proliferate, and I feel as though there is extreme risk for Japan's foreign policy as well" (2015: 266). These attitudes are widely shared among Japanese scholars of Islam and the Middle East, but are widely debated in society, and the current political leadership tends to dismiss such concerns.

Secondly, there are those who view Japan as a Unique Contributor to international society. Western interventions in Muslim Asia are permissible; that is what they do. Japan, however, should never take part due to its role. This is a view expressed by some scholars of Islam and the Middle East, insofar as they choose to focus only on Japan's image and role, and say nothing about the interventions, themselves. Fuse Hiroshi points out that in the Middle East, Japan's “image as a peaceful, economic power is strong. It is out of place for Japan to take part in military assistance in the Middle East, and it does not seem as if the people there are expecting this from us" (2015: 34). Naitō Masanori writes: 
As a result of the negative view towards military cooperation, Japan has not built up adversaries around the world... This is the power of Japan's brand, and must also be its historical heritage. Therefore, being able to use collective self-defense is, in a word, dangerous. It will only increase animosity among neighboring countries and create a state of tension; it is not defense (2015: 224-25).

Both of these thoughts reflect a role for that they do not want revised. Like the first group, they also detest the withering of Japan's norms of non-interventionism, Article IX, and non-militarization, but also accept the urge for someone to securitize Islam - just not Japan.

This is an interesting view, and it seems to reflect a wide swath of both Japanese society and the political class. In a 2016 survey by scholar Fukuda Mitsuru at Nihon University, he asks the question: "Is the threat from radical Islamic terrorism toward Japan increasing?" To this, 83.2 percent of Japanese adults responded affirmatively (2016: 146). Yet, in the same survey he asks, "Should Japan actively participate in the War on Terror to combat groups like ISIS?” To this, only 31.8 percent responded affirmatively (2016: 146). Therefore, one could surmise at least a third of the country senses a threat from Islamic terrorism, but at the same time does not want to confront it with the use of force. This view was also evident in April 2018 when the U.S., UK, and France bombed government sites in Syria. The strike was controversial globally, but Tokyo was quick to express its support, and likely relieved it was not asked to join. This group sees that security threats do emanate from Islam, but are adamant it is not Japan's role to be part of the security sector, due to institutional constraints that have shaped Japan's identity. In other words, non-militarism is uniquely for Japan; not for everyone. The position is anything but a revolutionary one; there is no proclivity to induce systemic 
transformations. Rather, Japan has its role in global politics, and militarism is not part of that self-image.

Lastly, there are those who would accept Japan as a Securitizer of Islam. A intervening coalition including Japan, assuming varying degrees of self-constraining rules, is permissible, which is the position usually displayed by Abe and many of the current political elites. This group is increasingly formulating foreign policy according to a Realpolitik understanding of Asia. While many observers claim Abe and Asō are motivated by nationalist proclivities, it appears here that realist thinking dominates, and nationalist behavior is a tool to support a realist foreign policy. They see the rise of China and the decline of the U.S., and are pursuing the strengthening Japan's defensive capabilities in the interest of balancing power. These measures are starkly opposed by Japanese scholars of Islam over the concern Japan will become an intervening force, whether by its own volition or obligation to the U.S. This group also includes Tokyo Governor Koike Yuriko, who is an Arabist, but also supporter of reinterpretation of Article IX and Japan's right to collective self-defense.

While the more conservative political elites such as Abe, Asō, and Koike often display the characteristics of the last group, less-conservative political elites have actually demonstrated less interest in developing relations with Muslim Asia countries, altogether, regardless of interventions. When the DPJ was in power from 2009 until 2012, two interesting developments occurred. First, the party still pursued Japan joining in counterpiracy measures in the Gulf of Aden and opening a Japanese SDF base in Djibouti. Second, the DPJ was notably focused on strengthening relations with East Asian neighbors China and South Korea, and compared to conservative LDP leaders like 
Asō who proposed the Arc of Freedom and Prosperity, DPJ leaders demonstrated notably less interest in developing Japan's ties with Muslim Asia through any facets of contact (Sakai 2016, 118). In fact, none of the three DPJ prime ministers from 2009 to 2012 even visited the Middle East or anywhere else in Muslim Asia, save for two separate international conferences in Indonesia.

Abe calls his defense agenda 'proactive pacifism.' This term has been detested among many of his critics as a nonsensical notion, but it does express an interest in bridging the divide between the roles as a pacifist, non-militarized great power, and at the same time emerge as a 'normal nation' with a SDF actively contributing to stabilization of order in Asia. It also makes his revisions somewhat more palatable to the second group listed above. What many see as an inter-role conflict, whereby there are "clashing role expectations about self and others," Abe believes he can bridge (Harnisch et al. 2011, 256). Abe has not outright abandoned Japan's identity, but seeks to modify it due to structural dynamics, undoubtedly with risks. "Inter-role conflict will often also produce intra-role conflicts (domestic contestation of role conceptions) and they also might have considerable impact on the international social order" (Harnisch et al. 2011, 256). SDF, however, is an armed force with an obvious use-of-force component. When Abe introduced this notion of proactive peace in his address to the UN General Assembly in September 2013, he declared: "I pledge here that I will make Japan a force for peace and stability, just as it has been until now - or rather, to a degree even greater than it has been thus far," and linked this role for Japan as a proactive peace force particularly in regard to the free and open seas, maritime order, and international rule of law: "For Japan, whose national interests are firmly connected to the stability of seas that are open, changes to the 
maritime order through the use of force or coercion cannot be condoned under any circumstances" (2013b). What is the compelling component behind this "cannot be condoned" declarative language? It is difficult to see how proactive pacifism will resemble anything like pacifism.

This chapter demonstrates that any consideration of Japan's position on sanctions and interventions in Muslim Asia cannot take place without properly considering the role of the U.S. Japan has demonstrated doubt regarding the effectiveness of economic sanctions, despite sharing the concern of nuclear proliferation. Moreover, Japan has demonstrated a willingness to make sanctioning malleable based on a hierarchy of needs and values. All the while, Japan has made tremendous sacrifices to adhere to the sanctions regime against Iran to resolve a security threat mutually shared with a strategy is does not firmly support. Again, Idemitsu's thinking can be applied here; Japan adhered to, and endured the U.S.-led sanctions regimes in accordance with its international loyalty, as Japanese. The U.S. military interventions in Muslim Asia have induced changes to Japan's identity as a pacifist nation, making it behave more like a 'normal nation.' Whether Japan will become a 'normal nation' is a question not yet resolved. Naitō expresses concern over this dynamic: "To think that in the Middle East, Japan must return a favor [ongaeshi] because the U.S. protects East Asia - if this is the idea, it will bring about extraordinary risk not just for Japan but for the world" (2015: 6). As discussed in Chapter 6, ongaeshi is integral to Japanese thinking, which means Japan's willingness to join the American 'Coalition of the Willing' means it did this with the expectation of reciprocal support if and when it is needed. The assumption of returning the favor is reinforced by Japan's shame culture and the Gulf Trauma it endured. 
This chapter uses the term 'reluctant acquiescence' to describe Japan's attitude toward commitments to the U.S. regarding sanctions on Iran, and it also describes Japan's approach to the War on Terror as well. Holsti describes such a role as 'faithful ally,' although he points out that very few faithful allies truly exist. "For many states alliances are potentially useful for protective purposes, but the state which receives an external guarantee does not reciprocate by supporting the guarantor" (1970: 267). In this case, considering the concept of ongaeshi, we see that Japan is taking the role of faithful ally, but other roles and normative proclivities create contrast with the role as faithful ally, and reveal a reluctance in behavior. 
Table 8.1: Iranian Crude Export Destinations (thousand bbl/d)

\begin{tabular}{llllll}
\hline consumer & 2006 & consumer & 2011 & consumer & 2017 \\
\hline 1. Japan & $\mathbf{4 4 8}(\mathbf{1 8 \%})$ & 1. China & $543(21 \%)$ & 1. China & $648(25 \%)$ \\
\hline 2. China & $335(13 \%)$ & 2. India & $341(13 \%)$ & 2. India & $502(19 \%)$ \\
\hline 3. India & $305(12 \%)$ & 3. Japan & $\mathbf{2 5 1 ( 1 0 \% )}$ & 3. S. Korea & $314(12 \%)$ \\
\hline 4. S. Korea & $204(8 \%)$ & 4. S. Korea & $239(9 \%)$ & 4. Turkey & $165(6 \%)$ \\
\hline 5. Italy & $191(8 \%)$ & 5. Turkey & $217(9 \%)$ & 5. Italy & $155(6 \%)$ \\
\hline 6. Turkey & $179(7 \%)$ & 6. Italy & $204(8 \%)$ & 6. Japan & $\mathbf{1 3 8 ( 5 \% )}$ \\
\hline 7. France & $135(5 \%)$ & 7. Spain & $170(7 \%)$ & 7. UAE & $127(5 \%)$ \\
\hline 8. S. Africa & $127(5 \%)$ & 8. Greece & $158(6 \%)$ & 8. Spain & $114(4 \%)$ \\
\hline other & $579(23 \%)$ & other & $404(16 \%)$ & other & $341(13 \%)$ \\
\hline TOTAL & $2,503(100 \%)$ & TOTAL & $2,527(100 \%)$ & TOTAL & $2,620(100 \%)$ \\
\hline
\end{tabular}

Source: adapted from U.S. Energy Information Administration

Table 8.2 Oil Consumption Jan. - Jun. 1990 (million bl/day)

\begin{tabular}{cccc}
\hline & OECD total & U.S. & Japan \\
\hline total consumption & 37.9 & 17.0 & 5.5 \\
crude \& product imports & 28.9 & 8.5 & 5.3 \\
\hline Persian Gulf imports & 9.7 & 2.1 & 3.3 \\
total consumption share & $25.6 \%$ & $12.4 \%$ & $60.0 \%$ \\
\hline Iran imports & 1.6 & negligible & 0.32 \\
share of Gulf exports & $16.5 \%$ & $<1 \%$ & $9.7 \%$ \\
total consumption share & $4.2 \%$ & $<1 \%$ & $5.8 \%$ \\
\hline Iraq imports & 1.7 & 0.58 & 0.25 \\
share of Gulf exports & $17.5 \%$ & $27.6 \%$ & $7.6 \%$ \\
total consumption share & $4.5 \%$ & $3.4 \%$ & $4.5 \%$ \\
\hline Kuwait imports & 1.1 & 0.16 & 0.39 \\
share of Gulf exports & $11.3 \%$ & $7.6 \%$ & $11.8 \%$ \\
total consumption share & $2.9 \%$ & $0.9 \%$ & $7.1 \%$ \\
\hline Qatar imports & 0.25 & negligible & 0.24 \\
share of Gulf exports & $2.6 \%$ & $<1 \%$ & $7.3 \%$ \\
total consumption share & $0.7 \%$ & $<1 \%$ & $4.4 \%$ \\
\hline Saudi Arabia imports & 3.5 & 1.3 & 0.82 \\
share of Gulf exports & $36.1 \%$ & $61.9 \%$ & $24.8 \%$ \\
total consumption share & $9.2 \%$ & $7.6 \%$ & $14.9 \%$ \\
\hline UAE imports & 1.3 & 0.02 & 1.1 \\
share of Gulf exports & $13.4 \%$ & $1.0 \%$ & $33.3 \%$ \\
total consumption share & $3.4 \%$ & $0.1 \%$ & $20.0 \%$ \\
\hline
\end{tabular}

Source: adapted from CIA Freedom of Information Act Collection, 1990 
Table 8.3: Major SDF Deployments*

\begin{tabular}{|c|c|c|c|}
\hline Location & Mission & SDF No. & Task \\
\hline Persian Gulf & Recovery assistance & & \\
\hline Marine SDF & Apr. 1991-Sep. 1991 & abt. 510 & minesweeping \\
\hline \multicolumn{4}{|c|}{ PKO Law enacted in June 1992} \\
\hline Cambodia & UN PKO & & \\
\hline Ground SDF & Sep. 1992-Sep. 1993 & abt. 600 & $\begin{array}{l}\text { repair infrastructure \& supply food, } \\
\text { medicine }\end{array}$ \\
\hline Mozambique & UN PKO & & \\
\hline Ground SDF & May 1993-Jan. 1995 & abt. 50 & coordinate transport operations \\
\hline $\begin{array}{l}\text { Rwanda } \\
\text { combined }\end{array}$ & $\begin{array}{l}\text { Refugee assistance } \\
\text { Sep. 1994-Dec. } 1994\end{array}$ & abt. 380 & material and personnel airlift \\
\hline $\begin{array}{l}\text { Golan Heights } \\
\text { combined }\end{array}$ & $\begin{array}{l}\text { UN PKO } \\
\text { Feb. 1996-Jan. } 2013\end{array}$ & abt. 50 & $\begin{array}{l}\text { transportation logistics for UN } \\
\text { Disengagement Observer Force }\end{array}$ \\
\hline $\begin{array}{l}\text { East Timor } \\
\text { Ground SDF }\end{array}$ & $\begin{array}{l}\text { Refugee assistance } \\
\text { Nov. 1999-Feb. } 2000\end{array}$ & abt. 110 & material and personnel airlift \\
\hline $\begin{array}{l}\text { Afghanistan } \\
\text { combined }\end{array}$ & $\begin{array}{l}\text { Refugee assistance } \\
\text { Oct. 2001-2014 }\end{array}$ & abt. 140 & material and personnel airlift \\
\hline \multicolumn{4}{|c|}{ Antiterrorism Special Measures Law enacted in November 2001} \\
\hline $\begin{array}{l}\text { Indian Ocean } \\
\text { Marine SDF } \\
\text { Air SDF } \\
\end{array}$ & $\begin{array}{l}\text { Anti-terrorism } \\
\text { Nov. 2001-Nov. 2007; } \\
\text { Jan. 2008-Jan. 2010 }\end{array}$ & abt. 320 & $\begin{array}{l}\text { refueling support for, and material } \\
\text { supplies to allies }\end{array}$ \\
\hline $\begin{array}{l}\text { East Timor } \\
\text { Ground SDF }\end{array}$ & $\begin{array}{l}\text { UN PKO } \\
\text { Feb. 2002-Jun. } 2004\end{array}$ & abt. 550 & repairs of roads, bridges, and reservoirs \\
\hline $\begin{array}{l}\text { Iraq } \\
\text { combined }\end{array}$ & $\begin{array}{l}\text { Refugee assistance } \\
\text { Mar. 2003-Apr. } 2003 \\
\text { Jul. 2003-Aug. } 2003 \\
\end{array}$ & $\begin{array}{l}\text { abt. } 50 \\
\text { abt. } 100\end{array}$ & $\begin{array}{l}\text { material and personnel airlift } \\
\text { material and personnel airlift }\end{array}$ \\
\hline Iraq & Recovery assistance & & \\
\hline Ground SDF & Jan. 2004-Sep. 2006 & abt. 700 & $\begin{array}{l}\text { medical, water treatment, rebuild public } \\
\text { facilities }\end{array}$ \\
\hline Marine SDF & Feb. 2004-Apr. 2004 & abt. 320 & transport vehicles and equipment \\
\hline Air SDF & Dec. 2003-Dec. 2008 & abt. 210 & material and personnel airlift \\
\hline Gulf of Aden & Counterpiracy & & \\
\hline Marine SDF & Mar. 2009-present & abt. 400 & merchant ship escort, surveillance \\
\hline \multicolumn{4}{|c|}{ Anti-Piracy Law enacted in July 2009} \\
\hline Djibouti & Base & abt. 180 & \\
\hline Marine SDF & Jun. 2011-present & & $\begin{array}{l}\text { facilitates for counterpiracy operations, } \\
\text { evacuation preparation }\end{array}$ \\
\hline South Sudan & UN PKO & & \\
\hline Ground SDF & Nov. 2011-May 2017 & abt. 350 & $\begin{array}{l}\text { road and infrastructure construction; } \\
\text { rescue of peacekeepers (from Nov. 2016) }\end{array}$ \\
\hline
\end{tabular}

* Excludes deployments of less than 50 soldiers and disaster relief missions. 
Table 8.4: Competing Roles Evident in the Japanese View on Interventions

\begin{tabular}{|c|c|c|}
\hline Japan as Islam Securitizer & Japan as Unique Contributor & Japan as Pacifist \\
\hline West interventions are condoned & West interventions are condoned & $\begin{array}{l}\text { West interventions are } \\
\text { condemned }\end{array}$ \\
\hline Islam as threat & Islam as threat & Does not consider Islam a threat \\
\hline SDF participation is condoned & SDF participation is condemned & SDF participation is condemned \\
\hline Universal roles & Unique Roles & Universal roles \\
\hline $\begin{array}{l}\text { Japan is a 'proactive pacifist' } \\
\text { state who joins with U.S.-led } \\
\text { coalitions in Muslim countries }\end{array}$ & $\begin{array}{l}\text { Japan is a (proactive) pacifist } \\
\text { state and ally to U.S., but } \\
\text { contributes to global order in } \\
\text { unique ways }\end{array}$ & $\begin{array}{l}\text { Japan is a pacifist state and } \\
\text { proselytizes pacifism globally }\end{array}$ \\
\hline $\begin{array}{l}\text { 'normal nation' defined by freer } \\
\text { use of SDF in overseas } \\
\text { coalitions, including in Muslim } \\
\text { states }\end{array}$ & $\begin{array}{l}\text { 'normal nation' may be defined } \\
\text { by freer use of SDF, but even so } \\
\text { conflict in Muslim states are not } \\
\text { Japan's fight }\end{array}$ & $\begin{array}{l}\text { 'normal nation' rejected, as it } \\
\text { implies adapting to neo-colonial } \\
\text { behavior, which is } \\
\text { counterproductive to peace and } \\
\text { prosperity }\end{array}$ \\
\hline
\end{tabular}




\section{CHAPTER IX}

\section{CONCLUSION}

Louis D. Hayes argues that “Japan's foreign relations, those of a formal sort having existed for a relatively short time, have been shaped by two dominant factors: isolation and dependence" (2018: 195). This is a most appropriate framing to reach a conclusion on Japan's relations with Islam in Asia. Unlike the late nineteenth century British notion of splendid isolation, Japan's isolation cannot be 'splendid' because it is simultaneously dependent on the outside world. Local life is broadly homogeneous, often chooses to look inward, and often frames the world in a binary uchi/soto (inside/outside) mode, increasingly eschewing much of gaikoku (the outside world). Problems in gaikoku, like Islamic terrorism, are often considered as distant, and Japan is neither here nor therenot even on the same map. Yet, the state must be deeply engaged. Moreover, if 'isolation' is interpreted in terms of 'distance,' the two variables can be considered in terms of quantifiable, interval measurements. Thus, dependency and distance shape foreign policy. How does this relate to Islam? How does it relate to Asia?

Concerning distance, there is considerable geographical distance between Japan and Muslim Asia. Yet, with the construction of a notion of a Greater Asia, ideational distance is nearer than before. Secondly, dependency is predicated on an innate sense of inferiority, not inferiority of the people or state, but to the contrary, an inferiority within the international system that it cannot sustain in isolation as a resource-poor state. This view is predicated on a view of Self as a power in the international system akin to the U.S., China, or Russia, but without their advantages of resource abundance. Thus, economic exchange comes from a position of state survival, not necessarily state wealth: 
bring in resources to develop and sustain a modern state, and export products to global consumers to bring back and accumulate capital - all to sustain Self. Therefore, it creates a dovetailing of geo-economics with geopolitics in Japan's foreign policy. The flow of this economic exchange must be steady, without disruptions, and therein lies the Islam factor. Islam presents a potential to disrupt the flow of this economic exchange. Yet, at the same time, Muslim consumers of Japanese products are also an opportunity in this exchange. Islam can decrease Japan's security; Muslims can increase Japan’s security.

This argument falls squarely in the paradigm of realist thinking, despite the tendency of some realists to overlook factors such as resource dependency, markets, and most significantly, religion. Yet, it is realist because it focuses on state survival. Traditional security is provided for Japan through its arrangements with the largest power, the U.S., but bandwagoning came serendipitously, and allowed for the Yoshida Doctrine, putting economics first for the sake of state survival. In 1965, Pakistani Foreign Minister (and later Prime Minister) Zulfikar Ali Bhutto called the Japanese "economic animals," in what was a backhanded compliment. Economic exchanges have long taken a dominant position in Japan's relations with Muslim Asia, and this is reflected in the Yoshida Doctrine, the Fukuda Doctrine, the Nikaidō statement, and an underlying sense of a volatile existence, as a state with negligible natural resources. Scarcity underscores insecurity, but rather than leading to violent conflict (again), stability is the means to ensure and perhaps even improve Japan's vitality. To survive, it needs to put economic interests first, which means a steady supply of energy resources, constant output of export products, and political stability among all trading partners. This is why Japan's vision for Asia is predicated on order before justice. And order comes about through stability, 
which is reinforced by economic development, democracy, and emphasized here, harmony.

At the same time, however, none of this explains the Arc, and values-based diplomacy. Japan is not forced to promote its values to ensure stability for this resourcesin, products-out strategy in foreign policy. This is where the constructivist perspective is useful to reveal role, identity, and norms. Through maturity of its own economic and political system, Japan has discovered in the last quarter century that it has a model which can be emulated, and it can proselytize. This model is for the good-it targets the security of a way of being. It is different than the liberal democratic model offered by the West; it is different than the illiberal democratic model offered by Moscow; and, it is different than the state capitalist model offered by Beijing. This is putting geo-culture at the forefront of Tokyo's foreign policy.

In fact, there is very little correlation between model proselytizing and dependency, or model proselytizing and distance. Indonesia is among the highest cases of model proselytizing, and is a state on which Japan is highly dependent and among the nearest of Muslim Asia. Yet, Kyrgyzstan is also among the highest cases of model proselytizing, but is a state on which Japan is hardly dependent and among the farthest away. Illustrated from these cases, there is more correlation between strength of democracy in the Muslim Asian state and Japan proselytizing its model (see Figure 9.1). Perhaps it is the most remarkable finding in this project that Japan is demonstrating itself as something replicable to states across Muslim Asia. This defies the arguments that the ideological predisposition of Nihonjinron, or some sort of Japanese exceptionalism drives foreign policy. Rather, evidence here shows a perceived likeness, and a solution based on 
empiricism. It demonstrates an approach of 'we did it this way; so can you.' This is illustrated in Akamatsu's Flying Geese Theory (FGT), Asō's analogy of the 'escortrunner,' and the view that Japan is leading Asia. It is also evident in the 'help, to selfhelp' approach to ODA. It is not charitable giving, but rather ongaeshi - 'we lend to you, we work together for your development, and it results in a positive sum outcome for both of us as well as a deepened long-term relationship.'

Japan, Religion, and Securitization

How does this modeling reconcile with the securitization of Islam? To reach a response to this question, a brief outline of religion and the state in Japan is necessary. Article XX in the Constitution in Japan ensures separation of religion and state, and U.S. authorities did much to drive a wedge between religion and the state during the postwar occupation by dismantling what they called "State Shintoism," but religious undertones are obvious in many aspects of Japanese society, including the public and political sphere. Broadly, religious identity is weak, yet religious practices, values, and ethics are strong. In fact, these characteristics persist in modernity precisely because identity is weak. By this, practices, values, and ethics persist because followers carry these out as Japanese, not as Buddhist, Shinto, or Confucianist. Moreover, society is significantly influenced by a hybrid of all these religions. The norm is to synergize. Therefore, monotheism can appear baffling to Japanese, as is religious exclusivity. This is true for Christianity, which makes up roughly two percent of the population, but Islam as well. In fact, the term for 'religion,' shūkyō (宗教), first appeared in the Japanese language during the nineteenth century to relate to the narrowly conceptualized English word (Reader and 
Tanabe 1998, 5). Therefore, many consider shūkyō to be limited to religious exclusivity and monotheism, more characteristic of Abrahamic traditions.

One example of a link between religion and state in Japan is the visits by political leaders to the controversial Yasukuni Shinto Shrine in Tokyo. In 1978, Yasukuni enshrined 14 Class-A war criminals together with the souls of nearly 2.5 million who fought in various wars, despite strong condemnation from China, South Korea, North Korea, and Taiwan. While not the first acting prime minister to visit Yasukuni, Koizumi Junichirō received international attention in the early 2000s when he visited the shrine to worship once every year he was in office. Abe Shinzō has made several visits as a parliamentarian, but only once as Prime Minister in December 2013. ${ }^{1}$ Asō Tarō visited and prayed at the Shinto shrine in October 2009 as a parliamentarian, but paradoxically, Asō happens to be Catholic. While condemned by neighbors, these visits were widely popular with the Japanese public. Both the LDP and opposition Constitutional Democratic Party of Japan (CDP) and Democratic Party for the People (DPP) take no official position on the shrine visits, and have parliamentarians who regularly visit. Kōmeitō, a party founded by, and maintains close links to the Sōka Gakkai sect of Buddhism, opposes visits and does not permit its members to do so.

There is a mainstream of religion (uchi) that is accepted as contributing to the Japanese lifestyle, and there are those which fall outside (soto) of this definition. Soto religion, at times, can be thought of in terms of cult, and in these cases securitized. Japan's only brush with religious terrorism in the postwar era came in the two sarin gas

\footnotetext{
${ }^{1}$ Since the enshrinement, all Japanese emperors have refused to visit.
} 
attacks in Matsumoto in 1994, and Tokyo in 1995, both from Aum Shinrikyō - a doomsday cult centered around a blind yoga instructor, Asahara Shōkō. These incidents were a critical juncture in the state's approach to religious terrorism. Prior to this, the state displayed very little interest or concern over religious groups - even soto religions. After these attacks, religious groups were looked at with suspicion (Cho and Katzenstein 2011, 183). There is no connection between Islam and Aum Shinrikyō, but the incidents spurred a heightened awareness of religious violence, which necessitated an imperative to securitize potential threats, and specifically threats originating from soto religion - those outside the mainstream of the constructed Self. After 11 September 2001, a global metanarrative has allowed this approach to coalesce into securitization of Islam in Japan as well. The Aum Shinrikyō attacks set a stage for securitization of soto religion in Japan; the global meta-narrative shifted that focus onto Islam.

Having established that Japan does securitize Islam because it was predispositioned to securitize religiously-inspired threats from Other prior to emergence of the global meta-narrative, this securitization manifests in very different ways. Japanese do not fear threats of Islamic terrorism in Japan's cities. Moreover, there is not the fear of a global jihad reaching the archipelago. Rather, the perceived threat revolves back to stability. Japan's existence is predicated on a level of global stability that allows for its resources-in, products-out strategy, which is the only means known for the state to survive. As this project illustrates, in the postwar era the biggest disruptions to resourcesin have come from conflicts in Islam. The 1973 oil shock, the Islamic Revolution in Iran, the Iran-Iraq War, Iraqi invasion of Kuwait, the Arab Spring, Saudi-Iranian rift, and the 
2017 Qatari diplomatic crisis elevated concerns in Japan about Islam as a disrupting force. Moreover, so are the nuclear ambitions of Pakistan, then Iran.

On the other hand, if Islam, as a thing, is a force that imperils Japan by creating risks to its security, Muslims, as people, are another force which offer expanding opportunities for Japan to improve its security. Securing consumer markets overseas is essential for bringing in capital, and thus, survival of the state, and Muslim Asia includes some of the fastest growing middle-class populations in the world. FGT is undoubtedly present in Japan's thinking of itself and Asia. So much so, it is a source of pride, because Japan views itself as the goose at the tip of the formation. It is also evident in the emphasis on "quality infrastructure" in Asia, while simultaneously using language to stress it is a model and form of development which Beijing would not be able to provide.

\section{Findings}

Having considered the dynamics how Japan reconciles the perceived threat from Islam in its foreign policy in Asia, this chapter proceeds by applying typological theory to the findings from the 'Strategy' portion of this project. Taking the findings into account, a theory is presented on differing ways Japan approaches Muslim Asia. In this typology there are four 'zones' of Islam identified across Muslim Asia (see Map 9.1). Two of these zones directly correspond with the regions of Muslim Asia presenting in Chapter 1, but these zones are fluid and can change. What they demonstrate is four views of Islam embedded in Japan's foreign policy, and therefore, four strategies Japan applies.

\section{Zone 1: Muslim Southeast Asia}

This is the most stable of the zones, although this is not to say it is entirely so. It includes the issue of Bangsamoro in the Philippines, insurgencies in Muslim-majority 
Southern Thailand, and religiously-inspired conflicts in Indonesia. Yet, it is most stable in the sense of Japanese engagement with the zone of a sizable 230 million Muslims. Both Bangladesh and Myanmar were up to recently part of this zone as long-term recipients of Japanese development assistance, but the July 2016 ISIS killing of seven Japanese nationals in Dhaka and ongoing Rohingya crisis in southeast Myanmar cause these two to slip into Zone 2. The Fukuda Doctrine set the normative rules for Muslim Southeast Asia. Muslims are a relatively significant factor in relations, but not so much Islam. In other words, Southeast Asian Muslims are crucial in Japan's knowledge and appreciation of Islam because of the depth and breadth of interpersonal relations. Business connections are strong, as are interpersonal relations via tourism, student exchanges, and international families. Indonesians, Filipinos, and Malaysians make up nearly half of the Muslims in Japan. Indonesian and Malaysians make up the largest number of Muslim tourists (nearly a quarter of a million annually, each), and rapidly increasing. Meanwhile, the largest overseas Japanese populations in Muslim Asia are found in this region.

From regional security complex theory, Buzan and Wæver argue that "insecurity is often associated with proximity," but this is not necessarily the case here (2003: 46). Rather, it counters Buzan's dictum on proximity, and is the least securitized Islam among the four by Japan. Regarding energy resources, Indonesia is the only essential supplier of coal to Japan in Muslim Asia, and Malaysia will remain an essential supplier of LNG for the next decade. Indonesia is of paramount importance for Japan's access to markets, and Java alone provides one of the most crucial industrializing population bases in the world. Indonesia has also been the single largest recipient of Japanese ODA. The region has 
been a favorite for Japanese FDI since the 1970s due to resource abundance, cheap and abundant labor, proximity to Japan, and a favorable political and social environment. Muslim minorities in countries such as Singapore and Thailand also make up some of Japan's biggest consumer markets. In the future, this relationship between Japan and Muslim Southeast Asia can potentially be strengthened through CPTPP, or some other form of an economic trade bloc. Insofar as soft power and export markets are objectives of Japan's ODA, Southeast Asia is a success story.

\section{Zone 2: Zone of Instability}

This is the most varied zone, largest, and probably the most fluid, but generally the zone of instability and the greatest perceived threats from Islam. A norm to securitize is reinforced in this zone through the following events: (1) in 1971 when the Japanese Red Army based itself in Lebanon; (2) the oil shock of 1973; (3) the 1979 Islamic Revolution in Iran which resulted in tremendous losses at Japanese FDI projects; (4) Pakistan securing nuclear weapons in 1998; and (5) Islamist terrorism in the twenty-first century, including several Japanese nationals killed in Iraq and Afghanistan since 2001, January 2015 two killed in Syria by ISIS, and the abovementioned July 2016 ISIS incident in Dhaka. While parts of the region have an energy security significance, these carry great risks for large-scale investment.

Interestingly, much of the zone is congruent with an axial corridor identified by Alfred Thayer Mahan in his 1900 work, The Problem of Asia and Its Effect on International Politics, as the "debatable and debated ground." Viewing this zone as a stretch of Asia across 40 to 30 degrees north latitude (see Map 9.2), Mahan prophetically wrote: "Between these two parallels are to be found, speaking roughly, the most decisive 
natural features, and also those political divisions the unsettled character of which renders the problem of Asia in the present day at once perplexing and imminent" (1900: 21). Included in this zone "are the Isthmus of Suez, Palestine and Syria, Mesopotamia, the greater part of Persia, and Afghanistan - with the strong mountain ranges that mark these two countries and Armenia - the Pamir," and "the cities of Aleppo, Mosul, and Bagdad [sic], of Teheran and Ispahan, of Merv and Herat, Kabul and Kandahar" (1900: 21-22). He adds: "No one of these is in the territory of a state the stability of which can be said to repose securely upon its own strength, or even upon the certainty of non-interference by ambitious neighbors" (1900: 22). Mahan also points out that, in fact, the greater part of Japan's territory and "the centre of her power" also lies within this belt (1900: 22). While more known for his theory on naval power, Mahan's works have been widely translated in Japan, and served as the most influential readings in the subfield of geopolitics since it was introduced as a discipline (Sawabe 2017,26). His The Influence of Sea Power upon History (1890) was an assigned textbook in all secondary schools and teacher's colleges by the Meiji Emperor (Sawabe 2017, 26-27). Therefore, it is plausible that a strand of Mahan's prophetic description of this zone persists in Japan's foreign policy view today. Iran and Iraq are both potential essential suppliers of crude oil, and when Iran completes its first LNG export complex, it could become an essential supplier of LNG as well. Both, however, currently provide energy resources for Japan in constrained amounts. While securitization of Islam partially explains risk with both Iraq and Iran, the U.S.-led interventions in Iraq and sanctions against Iran, respectively, exacerbate this risk. With Iraq, the risk continues with weak governance and ISIS. With Iran, the risk continues after the American withdrawal from the JCPOA. On top of this is Japan's 
normative concerns over nuclear proliferation, firstly, in Pakistan, and more recently, Iran. There is clear tepidness to deepen economic relations here, despite the opportunity it provides.

Risk continues beyond Mahan's zone, in Yemen, which has little to offer in terms of energy resources and amid a civil war, and the Gulf of Aden which Japan is actively using its marine SDF to secure. In some cases, Japan is attempting to resolve conflict. This is reflected in the diplomatic slogan, "the best way is to go in the middle," often reiterated by the Prime Minister and ministers of foreign affairs since January 2015, and also the Corridor for Peace and Prosperity in Palestine. In terms of interventions, however, Japan has reluctantly acquiesced in Iraq and Afghanistan, but when 'possible,' prefers to not be party to the security sector and instead taking the role Japan as a unique contributor.

Turkey is the most incommensurable of all states in Muslim Asia for this typology. The dependency variable is significant, not necessarily with energy exports, but rather, with a large and growing consumer base for Japanese products - a characteristic shared also with Egypt. Also shared between Turkey and Egypt are their transcontinental qualities, which contributes to their incommensurability. These characteristics, as well as Turkey's status as a secular state, make it more similar to Indonesia in Japan's view than any other Middle East country. While tempting to create a sui generis type for Turkey, it is in Zone 2 because of recent involvement in the war in Syria, occasional terrorist incidents, the failed coup attempt in July 2016, and President Recep Erdoğan's shifting away from the West (his autocratic power consolidation is of less concern). 


\section{Zone 3: Essential Suppliers}

This zone encompasses only the Persian Gulf energy suppliers. This zone once included Iraq and Iran, even recently, but not currently. Stability in this zone is a necessity at all costs, which means values, from the values-based diplomacy, are insignificant. There is very little discussion of human rights violations or democratic deficiencies in these countries. This calls for strategic pandering at times, such as during the 1973 oil shock, in the interest of ensuring steady access to energy supplies. The two most essential suppliers of crude oil are Saudi Arabia and UAE. Also essential, but at a lower threshold, are Qatar and Kuwait. Both Qatar and UAE are essential suppliers of LNG with deep bilateral ties built on this energy trade relationship. Saudi Arabia may also become an essential supplier of LNG, but not currently.

This form of relationship between Japan and these energy-suppliers, however, is very much temporary and a phenomenon of just the last six decades. It was Japan that ruined the Kuwaiti pearl industry in the past; it may be Japan which turns its back on Kuwaiti oil in the future. Saudi Arabia and UAE are already planning for post-oil economies. The Saudi-Japan Vision 2030 could be an important part of this post-oil era. Nevertheless, in the short- and medium-term, retaining supplies of fossil fuels is essential for Japan, but for the long-term, the energy resource dependency variable will dissipate from this relationship.

\section{Zone 4: "Secular Muslims"}

This zone includes all the post-Soviet republics in Central Asia, and to a much lesser extent includes Azerbaijan. The name of the zone, "Secular Muslims" denotes the positive distinction Asō remarked when describing the area in 2006. It also includes 
Xinjiang Province in western China, insofar as Japan has showed an inclination to support Uyghur dissent, to Beijing's chagrin, by allowing the World Uyghur Congress to meet in Tokyo in 2012, and the opening of Xinjiang Province by Beijing to restricted Japanese FDI only in the last decade. This zone is Japan's tabula rasa in terms of ODA and applying its values-based diplomacy. It is neither a major energy supplier nor export market for Japan, but a zone to 'cultivate' as an "escort runner." That is not to ignore the vibrant energy sectors in certain post-Soviet republics. Turkmenistan has the potential to be an essential supplier of LNG. Kazakhstan has the potential to be an essential supplier of coal and crude oil. Yet just a negligible amount of these states' resources makes their way to Japan's ports. China is actively reorienting the transport infrastructure in Central Asia to the east with BRI, but not as far east as Japan. Russia, meanwhile, is also motivated to prevent the resources from reaching Japan so that its own reserves in Sakhalin and Siberia remain more viable options. Russia is blocking Japan's access due to competition in supply; China is blocking Japan's access due to competition in demand. Nonetheless, Xinjiang provides new, but constrained FDI opportunities.

The fall of the Soviet Union opened the Central Asian republics to Japanese exports and FDI, which had been practically sealed off for over a century. Before China or the U.S., it was the Japanese who first used the slogan 'Silk Road Diplomacy' in 1997 to describe their foreign policy with the newly independent republics in Central Asia (Kawato 2008, 17-18). Since then, Japan has approached Central Asia to emphasize its values in young countries where it saw similarities to itself. One way this is done is through the application of Japan Centers, where Japan is instructing how development is done. Another way is the ongoing Central Asia Plus Japan Dialogues. These are displays 
of liberal normativity usually associated with the West, and an example of Japan defying its own proclivity toward an identity based upon uniqueness. Japan is admitting its model is replicable - and of all places, replicable in landlocked, resource-rich, sparselypopulated societies of 'secular Muslims.' Cultural, geographical, historical, and developmental indicators all show great differences with Japan, yet perceptions highlight the similarities. This is not about access to energy or access to markets; if these were all that drove Japanese foreign policy, it would have lost interest in Central Asia long ago. This is about role and identity.

\section{Theoretical Contribution}

Religion is a force that cannot be ignored because it informs epistemology, identity and role to varying degrees and in varying manners. In all its facets of interaction with Muslim Asia, Japan cannot escape the Islam variable in its strategy due to the contemporary global meta-narrative. This even applies in the "Secular Muslim" zone, where Asō felt compelled to draw the distinction. Moreover, Japan does not escape its own religiously-informed proclivity, which might not be well recognized. The theoretical contribution is the new approach to Islam. Japan does not evade global narratives of securitizing Islam, but this project shows another strategy to reconcile with it. Japan's approach is not the one taken by the West, Russia, or China. Dominating paradigms in international relations such as realism, liberalism, and Marxism, can account for some of Japan's behavior, but given that all three discount the religion variable, are lacking in explaining real world phenomena. 


\section{Further Research}

This project aims to give a thorough treatment to Japan's relations with Muslim Asia, and serve as an essential reference for anyone looking into this subject, but at the same time painstaking abridgement is necessary. Primary and secondary sources are extensive, and it comes as a pleasant surprise that such depth and breadth exists on this topic, but at the same time this project is filling a gap in the literature. Several research paths closely related to this project are left unpursued; here are five of those paths.

First, this project demonstrates that Muslim Southeast Asia has served as an essential gateway to broader Muslim Asia for Japan. In particular, Indonesia has served at the linchpin of that relationship. Indonesia has the world's largest Muslim population, and while it has not been immune to Islamic extremism and terrorist incidents - even ones in which Japanese citizens were killed and injured, such as the 2002 and 2005 Bali bombings - there is little evidence of broad securitization of Islam in Indonesia by Japan. On the contrary, the prevalence of Islam in Indonesia hardly weighs on the consciousness of Japanese who go there, or interact with it, as something which must be securitized. Why is this, and what kind of learning is taking place between Japan and Indonesia? Harry J. Benda's 1958 classic work, The Crescent and the Rising Sun, analyzes Indonesian Islam under Japanese occupation. While extensive and essential, it only focuses on this brief period. Japanese are encountering Islam through Indonesians more than anyone else, and increasingly so. What does this mean for the image of Islam?

Actually, this project reveals a number of linchpin countries within Muslim Asia, whereby a study specific to that country's relations with Japan would contribute to this research project. A lot of work on Japan's relations with Turkey has been done by 
scholars such as Renée Worringer and Bahadır Pehlivantürk, but much of it tends to overlook the Islamic factor, given that Turkey is nominally a secular state. Both Turkey and Japan share separate security arrangements with the U.S., peripheral statuses with the West, normative interests in Central Asia, and atonement issues with historical atrocities as empires. Also, Iran has a depth of bilateral relations with Japan that would complete an entire project, and again, would need to bring in the concept of reactionary relations to unpack mutual perceptions. Additionally, Japan has given special emphasis to the smaller Gulf emirates among its energy suppliers, namely Qatar and UAE. More can be written on this strategy, and obviously Islam permeates as a key factor in these relations.

Next, because this project focuses on foreign policy and mostly the political class, it does not open the discussion of comparative mysticisms between Islam, and Japanese teachings in Shinto and Buddhism. The late Izutsu Toshihiko pioneered this research project in the twentieth century, but there is much work to be added. Miyata Osamu occasionally emphasizes parallels between Islamic mysticism and Japanese teachings in Zen and the concept of füdo (風土) ('social-physical climate,' or 'environmental milieu') to support points in his work (2014a: $62-63 ; 2017: 260-61)$. Nonetheless, there is a dearth of substantial literature on this topic, particularly scholarship in the English language.

Third, the number of Muslims in Japan is small, but it is growing and their experiences are certainly worthy of extensive research. Miyata shares an anecdote of an Iranian long-term resident of a small town in Japan who passed away, and without knowledge of Islamic burial practices, local authorities had his body cremated, inevitably resulting in the Iranian embassy issuing a complaint (2017: 241). More recently, there was also a top-division Egyptian sumo wrestler, Ōsunaarashi, who struggled with the 
pressures to observe an intensive diet and training regimen while fasting during Ramadan. It can be challenging to conduct business in Japan without joining colleagues or clients in drinking alcohol. The duality of adherence to one's religious practices and the social expectations of life in Japan can reveal much about Japan and Islam, but also makes for a fascinating sociological study altogether. Some Muslim migrants to Japan have carved out a niche role in society, such as the case explored in Chapter 5 of Pakistanis facilitating a grey market for used automobile exports. Komura Akiko has done work in this field in Japanese, but, again, there is a dearth in the English language literature.

Fourth, this project 'splits the baby' as it were in terms of the scope of the Ummah and the Muslim world. Since this project examines Islam as part of Asia, from Japan's view, it looks at Islam from Mecca eastward. Indeed, in aggregate numbers, this is more than three-fifths of the Muslim world, but it does leave out a diverse array of Muslims from Mecca westward. Japan is very active on the continent of Africa in terms of energy, markets, ODA, and UN peacekeeping. What are Japan's encounters with Islam in Africa, and how have they shaped its view of both the religion and the continent? This goes into a region that forms a separate geoculture, and beyond the Arc framework, but nonetheless is the opening to a critical corresponding work. Egypt is an obvious bridge between the Middle East and Africa, and Japan has a vital relationship with Egypt, but because it (mostly) is not Asia this project does not extensively analyze Egypt's bilateral relations with Japan. Looking at Muslim Africa, Egypt is key, but so are Nigeria, Sudan, and Algeria. 
Lastly, this is a project whereby one could say Japan is the subject while Islam, or more specifically, Muslim Asia is the object of the research. It examines how Japan views Asia, and Islam as part of it. Japanese scholars of Islam often point out that many non-Japanese Muslims comment that Japan is a society that displays broad alignment with Islamic values, yet basic religious practices for Japanese include ancestor worship and cremation (Komura 2015, 229: Miyata 2017, 261-62). Is Japan truly a model for statecraft from the view of states in Muslim Asia? Are Japanese "economic animal" activities in Muslim Asia ever considered counterproductive to the interests of the people in these states? What is the conceptualization of Asia for Muslims from Turkey to Indonesia, how does Japan fit into that conceptualization, as well as the Ummah? A complementary study would be the reversal of this setup. While it appears briefly at different points in this project, a thorough analysis of how Muslims view Japan is needed. Within this idea, how do Muslims conceptualize Asia, as it relates to their own states, to the Ummah, and inclusive of Japan?

\section{Postscript}

The outcomes of this project allow for thoughts prospective in nature, to which this is, hopefully, just the beginning. There is the tendency among Japanese scholars of Islam to dwell on the favorable view Japan garners among Muslims in Asia. Sakai Keiko discusses this view in terms of an 'unrequited love':

Since the 1970s, the favorable view of Japan among Middle east countries is the counter side to the unfavorable view toward the West. The Middle East countries that suffered Western colonialism embrace the development of non-Western Japan with an endless yearning. This is a sentiment that you could call 'unrequited love' that has persisted since before the Second World War (2016: 123). 
In general, this is true, but at the same time it is an embellishment of the place Japan has in the consciousness of Muslims in Asia, particularly beyond Southeast Asia. In fact, inflating Japan's role in the international community is not unique to this group of scholars; rather, its common in Japanese society to do so. This was noted as early as 1984 by Masao Kunihiro: "There is an increasing tendency for even the ordinary people of Japan to overestimate Japan's worth" (1984: 48). In many cases, it is probably done because of publishers' interest to reach a wide readership, and to do so in Japan, in the Japanese language, to Japanese readers, necessitates lionizing the role of Japan in the international society.

There is risk in doing this. When Japan was omitted from the Kuwaiti statement of appreciation in 1991, when Japan became embroiled in conflicts such as the 2015 ISIS hostage crisis, or when Japan was left out of crucial negotiations such as the Iranian nuclear deal, it leaves the nation with a sense of bewilderment due to this understanding of an exaggerated role and broad favorability. In a 2015 Pew Research survey, 48 percent of Pakistanis indicated a favorable view of Japan and 15 percent an unfavorable view, but 37 percent either did not know or refused to respond (Stokes 2015, 14). In a similar survey by the BBC in 2014,40 percent of respondents in Turkey had a favorable view of Japan and 18 percent unfavorable, leaving 42 percent not knowing or refusing to respond (BBC 2014, 21-22). It is this 37 percent of Pakistanis and 42 percent of Turks which should be of concern. This is why dialogues, ODA activities, and FDI will remain crucial into the future. Japan's influence in Asia is increasingly eclipsed by China, which is nearer, larger, and much more willing to take risks with investments. Japan must 
preserve, if not, double down on its engagements to retain a stake in the consciousness of the Muslim societies in Asia.

Favorability is evidence of soft power. Japanese scholars of Islam as well as diplomats are prone to frequently highlight the popularity of Japanese arts, film, and popular culture in Muslim countries. This can be considered a tool of foreign policy, and there is no reason to fault political leaders for usurping these to their advantage. At the same time, however, these soft power advantages, which have taken a long time to build up, can vaporize in short order. Japan's refusal to admit Syrian refugees, for instance, can tarnish this reputation, just as poor use of hard power can. Therefore, it is crucial that Abe's proactive pacifism is done correctly, although it is not clear what 'done correctly' would entail. It is difficult to envision what comes out of this approach, but if it means Japanese soldiers will inevitably be in Muslim Asia "killing people and breaking things," as Colin Powell defined the job of a trained soldier, this favorability could vanish with just one mishap.

At the same time, humility is in order. In 2013, while Tokyo was competing against Istanbul to host the 2020 Summer Olympic Games, Tokyo Governor Inose Naoki made the comment: "In Islamic countries, the only thing they share in common is Allah and they are fighting with each other" (Belson 2013, D4). In the same interview, he pushed the narrative of Japan as exceptional, even citing Samuel P. Huntington's The Clash of Civilizations to justify his understanding that Japan was a unique civilizational state. As if the comments were not enough, he added, "I'm sure people in Turkey want to live long, and if they want to live long, they should create a culture like what we have in Japan. There might be a lot of young people, but if they die young, it doesn't mean 
much" (Belson 2013, D4). This attitude can easily induce behavior that would destroy the soft power advantage Japan has garnered over the decades.

In the postwar era, Japan has been remarkably successful in balancing its resource dependency, and export and FDI activities, with its U.S. alliance obligations and non-interventionist norms. Now, it is overtly bringing in its own values to its foreign policy in Muslim Asia. The model, based on a concept of harmony, is enticing to be sure, but the replicability of this model is questionable. Nonetheless, societal harmony is undeniably lacking throughout much of the world, and if this is the unique contribution Japan can make to Muslim Asia which would perpetuate growth, development, stability, and minimize the lure of religious extremism, it is for the world's benefit. 
Figure 9.1 Evidence of Values-Based Diplomacy and Level of Democratization

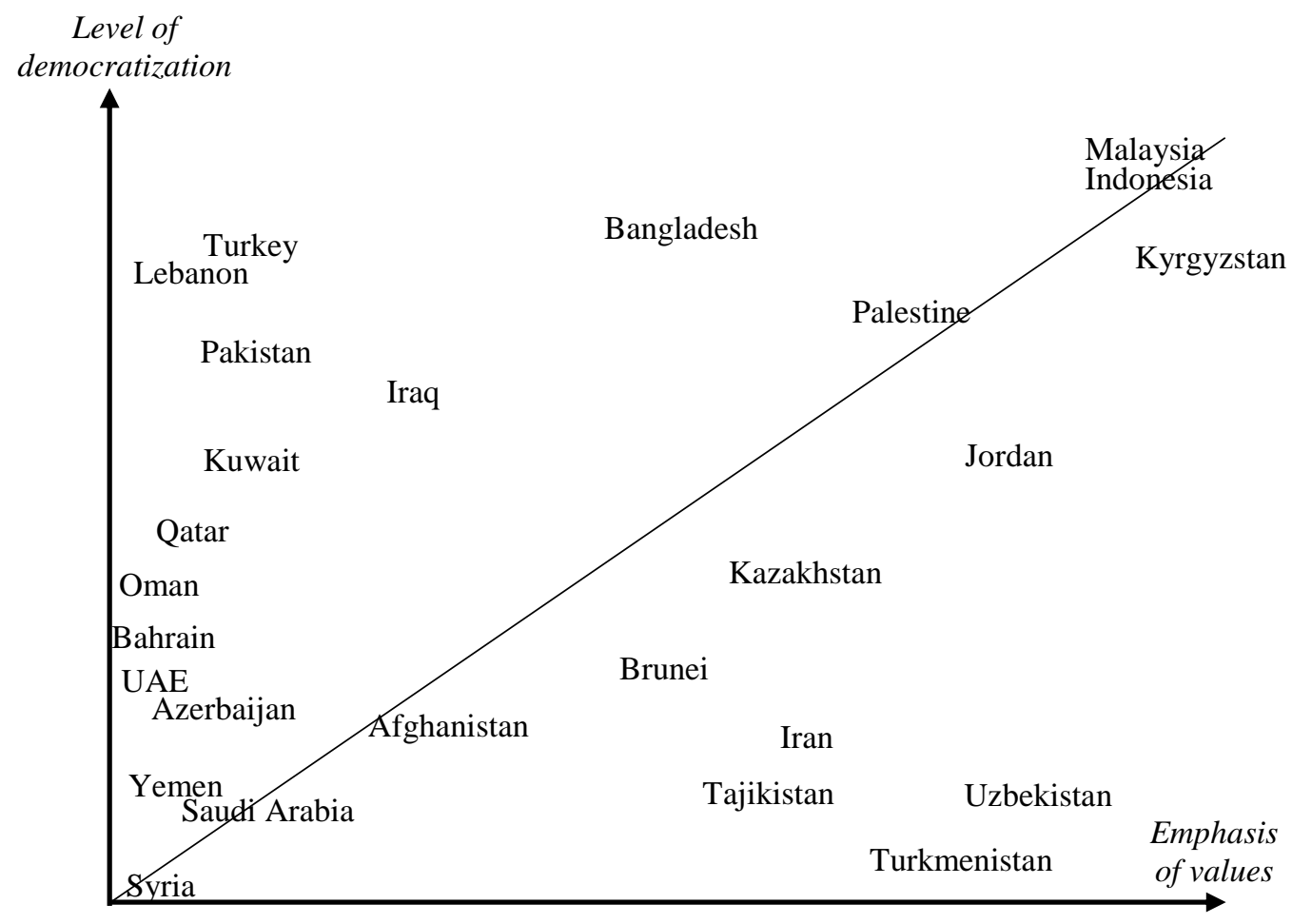


Map 9.1: Japan’s Zones of Islam in Asia

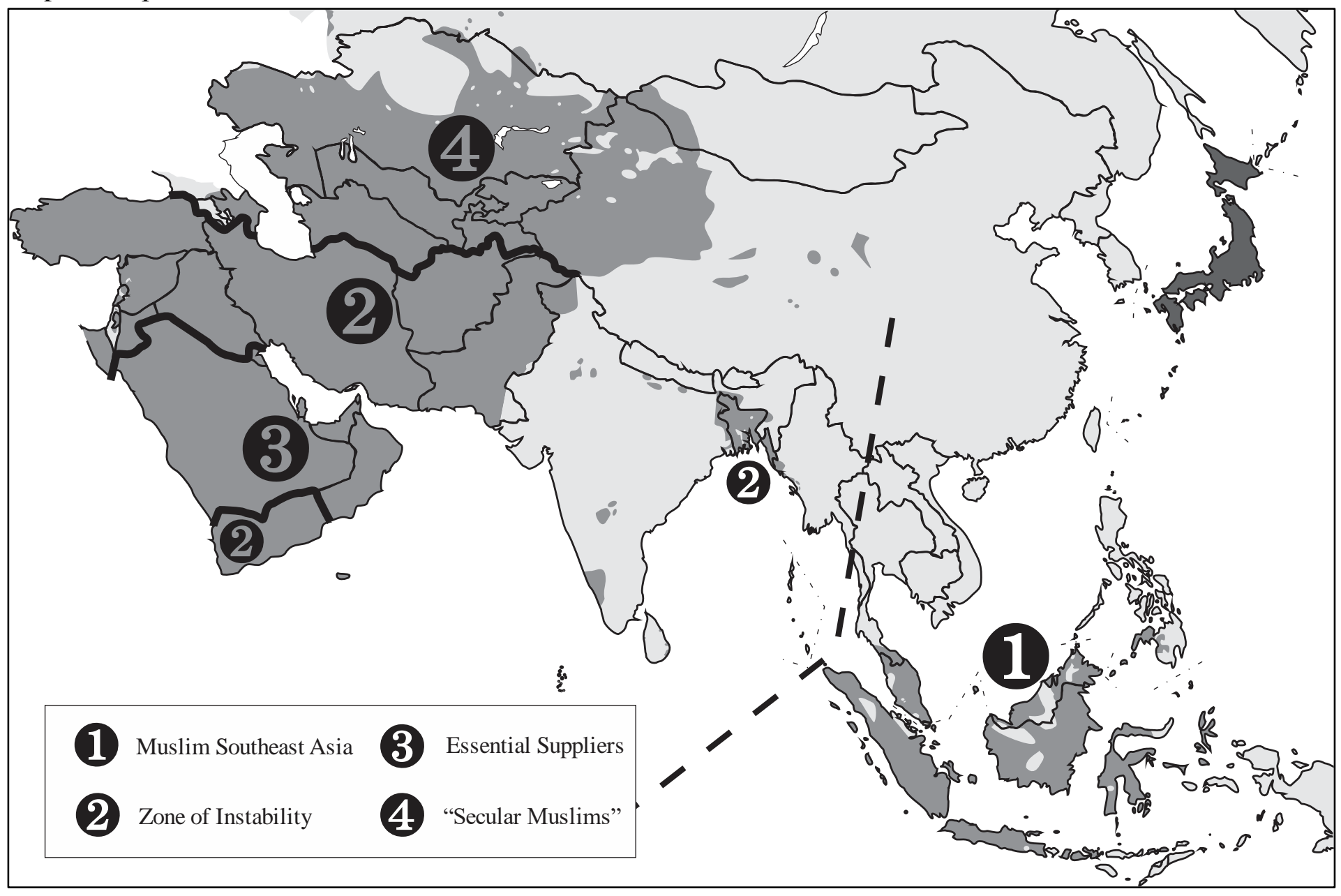

Map by author. 
Map 9.2: Mahan's "Debatable and Debated Ground"

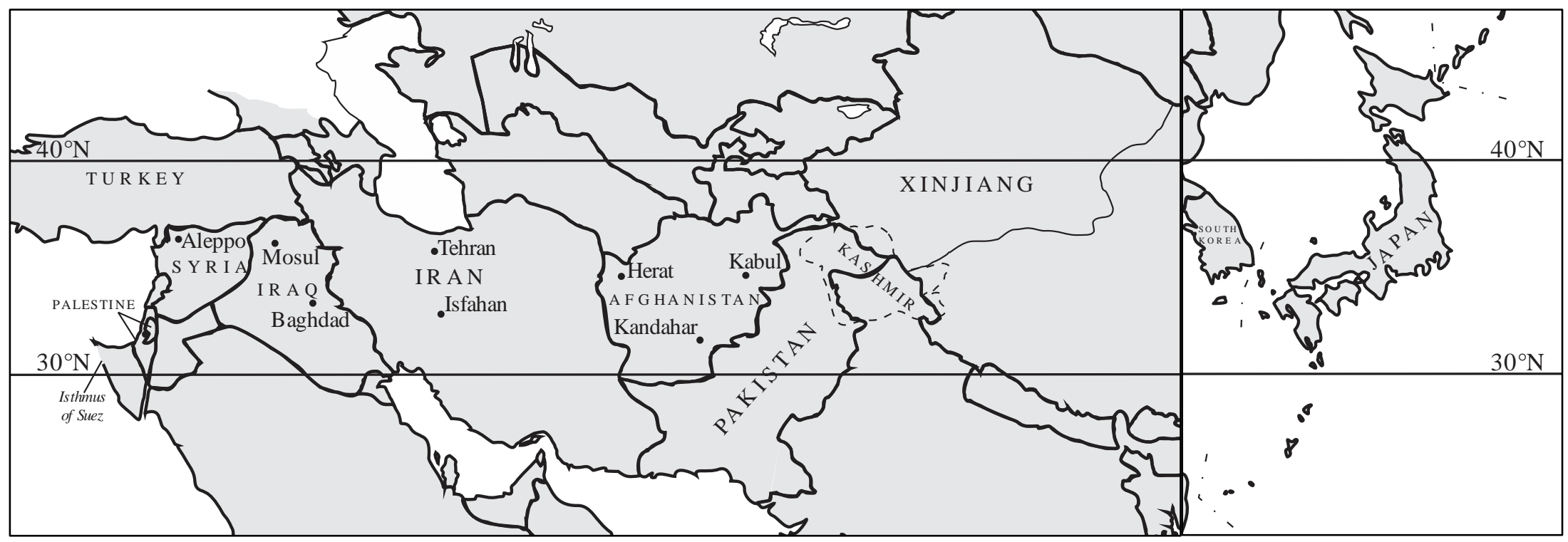

Map by author. 


\section{BIBLIOGRAPHY}

Abe Shinzō. From Preble, Christopher A. 2006. "Don't Count on Japan's Support for Sanctions." CATO Institute, 29 June. https://www.cato.org/publications/commentary/dont-count-japans-supportsanctions.

2012. “Asia's Democratic Security Diamond.” Project Syndicate, 27

December. https://www.project-syndicate.org/commentary/a-strategic-alliancefor-japan-and-india-by-shinzo-abe.

. 2013a. "Nichi-Iran shunō kaidan (gaiyō)" [Japan-Iran summit meeting (summary)]. Tokyo: MOFA, 26 September. https://www.mofa.go.jp/mofaj/kaidan/page24_000127.html (Japanese).

. 2013b. "Dai 68 kai kokuren sōkai ni okeru Abe naikaku sōri daijin ippan tōron ensetsu" [General discussion address by Prime Minister Abe Shinzō at the 68th UN General Assemby]. Transcript. Prime Minister of Japan and His Cabinet, 26 September.

https://www.kantei.go.jp/jp/96_abe/statement/2013/26generaldebate.html.

. 2015a. "The Best Way Is to Go in the Middle" (speech). Delivered on 18 January at the Egypt-Japan Business and Investment Seminar in Cairo. Prime Minister of Japan and His Cabinet. Transcript. http://www.kantei.go.jp/jp/97_abe/statement/2015/0117speech.html (Japanese).

. 2015b. "Address by Prime Minister Shinzo Abe at the Asian-African Summit 2015" (speech). Delivered on 22 April in Jakarta. Ministry of Foreign Affairs. Transcript. http://www.mofa.go.jp/mofaj/a_o/rp/page3 001191.html (Japanese).

. 2015c. "The Prime Minister Hosts an Iftar with the Islamic Diplomatic Corps in Japan," 30 June in Tokyo. Transcript. Prime Minister of Japan and His Cabinet. https://www.kantei.go.jp/jp/97_abe/actions/201506/30islam.html (Japanese).

. 2015d. "Policy Speech by Prime Minister Shinzo Abe in Kazakhstan." Delivered on 27 October at Nazarbayev University in Astana. Transcript. Prime Minister of Japan and His Cabinet. https://www.kantei.go.jp/jp/97_abe/statement/2015/1027speech.html (Japanese).

. 2015e. "Address by Prime Minister Shinzo Abe on the Occasion of the ASEAN Business \& Investment Summit," 21 November. Transcript. Prime Minister of Japan and His Cabinet. https://japan.kantei.go.jp/97_abe/statement/201511/asean.html. 
2016. "Address by Prime Minister Shinzō Abe at the "Shared Values and Democracy in Asia' Symposium" (speech). Delivered on 19 January in Tokyo. Ministry of Foreign Affairs. Transcript. www.mofa.go.jp/mofaj/s_sa/sw/page3_001543.html (Japanese).

. 2017a. "Asia's Dream: Linking the Pacific and Eurasia" (speech). Delivered on 5 June at the Banquet of the $23^{\text {rd }}$ International Conference on the Future of Asia, Tokyo. Prime Minister of Japan and His Cabinet. Transcript and video. https://www.kantei.go.jp/jp/97_abe/statement/2017/0605speech.html (Japanese).

. 2017b. "The Prime Minister Hosts an Iftar with the Islamic Diplomatic Corps in Japan," 9 June in Tokyo. Transcript. Prime Minister of Japan and His Cabinet. https://www.kantei.go.jp/jp/97_abe/actions/201706/09islam.html (Japanese).

. 2017c. "Message from Prime Minister Shinzo Abe on the Occasion of Marine Day 2017" (public message). Delivered on 17 July. Prime Minister of Japan and His Cabinet.

https://www.kantei.go.jp/jp/97_abe/discource/20170717uminohi.html (Japanese).

Abedin, Mahan. 2010. "Islam in Japan - An Interview with Professor Hassan Ko Nakata," Religioscope. 7 August. https://english.religion.info/2010/08/07/islamin-japan-an-interview-with-professor-hassan-ko-nakata/.

Abdul Rahman, Abdul Rahim. 2007. "Islamic Microfinance: A Missing Component in Islamic Banking.” Kyoto Bulletin of Islamic Area Studies 1, no. 2: 38-53.

Adler, Emanuel, and Michael Barnett. 1998a. "Security Communities in Theoretical Perspective." In Security Communities, edited by Adler, Emanuel, and Michael Barnett, 3-28. New York: Cambridge University Press.

, and Michael Barnett. 1998b. "A Framework for the Study of Security Communities." In Security Communities, edited by Adler, Emanuel, and Michael Barnett, 29-65. New York: Cambridge University Press.

Alberti, Mia. 2017. "Protests in Japan as Anti-Conspiracy Bill Passed." Al Jazeera 16 June. www.aljazeera.com/news/2017/06/protests-japan-anti-conspiracy-billpassed-170615155758951.html.

Al-Maraj, Rasheed M. 2009. "Islamic Finance Amid the Global Financial Turmoil.” BIS Review, no. 153: 1-4.

Aoi Tamotsu. 2015. "Iran seisai dōkō shijō seminā: iran no kaku mondai no keizai seisai" [Trends in Iran sanctions cover seminar: Iranian nuclear issue and economic sanctions]. CISTEC Journal, no. 159 (September): 108-29. 
Arab News. 2016. "Gov. Koike Speaks Fluent Arabic...and Feels Spiritual Connection with Arab World." Arab News, 4 September.

http://www.arabnews.com/node/979796/saudi-arabia.

Asahi Globe. 2014. "Nihon no musurimu 11 man nin" [110,000 Muslims in Japan]. The Asahi Shimbun Globe, 3 August. http://globe.asahi.com/feature/memo/ 2014080100024.html.

Asahi Shimbun. 2017. "China Offers to Buy 5\% of Saudi Aramco, Japan Also Interested." Asahi Shimbun, 17 October. www.asahi.com/ajw/articles/AJ201710170022.html.

Asō Tarō. 2006a. "Central Asia as a Corridor of Peace and Stability" (speech). Delivered on 1 June at Japan National Press Club, Tokyo. Ministry of Foreign Affairs. Transcript. www.mofa.go.jp/mofaj/press/enzetsu/18/easo_0601.html (Japanese).

. 2006b. "Arc of Freedom and Prosperity: Japan's Expanding Diplomatic Horizons" (speech). Delivered on 30 November at the Japan Institute of International Affairs, Tokyo. Ministry of Foreign Affairs. Transcript. www.mofa.go.jp/mofaj/press/enzetsu/18/easo_1130.html (Japanese).

Aydin, Cemil. 2007. "Beyond Eurocentrism? Japan's Islamic Studies during the Era of the Greater East Asia War (1937-1945)," in The Islamic Middle East and Japan, edited by Renée Worringer, 137-62. Princeton, NJ: Markus Wiener Publishers.

Azimi, Nassrine. 2010. “Japan’s Iran Moment.” The New York Times, 17 February. www.nytimes.com/2010/02/18/opinion/18iht-edazimi.html.

Badykova, Najia. 2016. "Japan's and China's Different Functions in Asia." The Central Asia-Caucasus Analyst, 16 January.

http://www.cacianalyst.org/publications/analytical-articles/item/13319-japansand-chinas-different-functions-in-asia.html.

Barber, B. Bryan. 2016. "Comprehensive Security 2.0: (Re)applying a Distinctive Security Concept to the 3/11 Disasters." Electronic Journal of Contemporary Japanese Studies 16, iss. 2 (August). http://www.japanesestudies.org.uk/ejcjs/vol16/iss2/barber.html.

. 2018. "Far, yet so Near: Normativity in Japan's Diplomacy with the Central Asian Republics." Asian Affairs: An American Review 45, no. 1 (February): 1839.

Bassin, Mark. 2016. The Gumilev Mystique: Biopolitics, Eurasianism, and the Construction of Community in Modern Russia. Ithaca, NY: Cornell University Press. 
BBC. 2013. "What Happened to Japan's Electronic Giants?” BBC News, 2 April. http://www.bbc.com/news/world-asia-21992700.

. 2014. "Country Rating Poll.” BBC World Service. https://downloads.bbc.co.uk/mediacentre/country-rating-poll.pdf.

. 2015. "Migrant Crisis: Japan Pledges \$1.5bn for Aid and Peace-Building." BBC News, 30 September. http://www.bbc.com/news/world-asia-34398411.

Bell, Daniel A. 2006. Beyond Liberal Democracy: Political Thinking for an East Asian Context. Princeton, NJ: Princeton University Press.

Belson, Ken. 2013. “In Promoting His City for 2020 Games, Tokyo's Bid Chairman Tweaks Others.” New York Times, 26 April: D4.

Benda, Harry J. 1958. The Crescent and the Rising Sun. The Hague, the Netherlands: W. van Hoeve Ltd.

Benedict, Ruth. 1946. The Chrysanthemum and the Sword. Boston: Houghton Mifflin.

Bowen, Roger W. 2003. Japan's Dysfunctional Democracy. New York: M. E. Sharpe, Inc.

BP. 2006. BP Statistical Review of World Energy. London: BP. 2011. BP Statistical Review of World Energy. London: BP. . 2016. BP Statistical Review of World Energy. London: BP.

Braun, Timothy F., and Lisa M. Glidden. 2014. Understanding Energy and Energy Policy. London: Zed Books.

Brooks, Andrew. 2011. "Networks of Power and Corruption: The Trade of Japanese Used Cars to Mozambique.” The Geographical Journal (March): 1-13.

Brown, Chris. 2014. "International Society, Cultural Diversity, and the Clash (or Dialogue) of Civilizations," in Civilizations and World Order, edited by Fred Dallmayr, M. Akif Kayapınar, and Ismail Yaylacı, 51-69. Lanham, MD: Lexington Books.

Bufton, Vicky. 2016. "What's in a Name? Vehicle Brands Market Shares in Turkey 2015." EMIS, 16 November. https://www.emis.com/blog/whats-name-vehiclebrands-market-shares-turkey-2015. 
Bull, Hedley. 1977. The Anarchical Society. New York: Columbia University Press.

Burrett, Tina. 2014. "An Inconvenient Truce: Domestic Politics and the Russo-Japanese Northern Territories Dispute," in Critical Issues in Contemporary Japan, edited by Jeff Kingston, 161-76. New York: Routledge.

Buzan, Barry. 1991, 1983. People, States \& Fear: The National Security Problem in International Relations. London: Wheatsheaf Books.

, Ole Wæver, and Jaap de Wilde. 1998. Security: A New Framework for Analysis. Boulder, CO: Lynne Rienner.

, and Ole Wæver. 2003. Regions and Powers: The Structure of International Security. New York: Cambridge University Press.

, and Lene Hansen. 2009. The Evolution of International Security Studies. New York: Cambridge University Press.

, and Ole Wæver. 2009. "Macrosecuritisation and Security Constellations: Reconsidering Scale in Securitization Theory," Review of International Studies 35: 253-76.

Catalinac, Amy L. 2007. "Identity Theory and Foreign Policy: Explaining Japan's Responses to the 1991 Gulf War and the 2003 U.S. War in Iraq." Politics \& Policy 35, no. 1: 58-100.

Chalabi, Fadhil. 2010. Oil Policies, Oil Myths. New York: I.B. Tauris \& Co. Ltd.

Chang, Gordon G. 2009. "Will Japan Become a Chinese Colony?” Forbes, 4 September. https://www.forbes.com/2009/09/03/japan-china-yukio-hatoyama-opinionscolumnists-gordon-chang.html.

Chen Liwei. 2011. “'Minshu' to 'kyōwa': kindai nitchū gainen no keisei to sono sōgo eikyō." Seijō keizai kenkyūsho [seijo economics research institute), no. 194 (November): 9-35.

Cho, Il Hyun and Peter J. Katzenstein. 2011. "In the Service of State and Nation: Religion in East Asia," in Religion and International Relations Theory, edited by Jack Snyder, 168-99. New York: Columbia University Press.

CIA. 1990. "Iraq/Kuwait; International Economic \& Energy Weekly DTD. 10 August 1990; Intern." Freedom of Information Act Collection, Electronic Reading Room, CIA. https://www.cia.gov/library/readingroom/document/0000407728. 
CIA World Factbook. 2018. Washington, D.C.: Central Intelligence Agency. https://www.cia.gov/library/publications/resources/the-world-factbook/.

Cirincione, Joseph. 2007. Bomb Scare. New York: Columbia University Press.

Clover, Charles. 1999. "Dreams of the Eurasian Heartland - The Reemergence of Geopolitics," Foreign Affairs 78, iss. 2 (April): 9-13.

Conlon, Michael. 2010. "The History of U.S. Cotton in Japan." USDA Foreign Agricultural Service GAIN Report, 12 April. https://gain.fas.usda.gov/Recent\%20GAIN\%20Publications/The\%20History\%20o f\%20U.S.\%20Cotton\%20in\%20Japan\%20_Tokyo\%20ATO_Japan_4-122010.pdf.

Conner, Phillip. 2018. "Most Displaced Syrians are in the Middle East, and about a Million are in Europe," Washington, D.C.: Pew Research Center, 29 January. http://www.pewresearch.org/fact-tank/2018/01/29/where-displaced-syrians-haveresettled/.

Cook, Malcolm. 2015. "Two Asias: AIIB v ADB.” The Straits Times [Singapore], 5 June. www.straitstimes.com/opinion/two-asias-aiib-v-adb.

Cooley, Alexander. 2012. Great Games, Local Rules. New York: Oxford University Press.

Corben, Tom. 2017. “Japan's Nuclear Exports: Risky Business.” The Diplomat, 22 December. https://thediplomat.com/2017/12/japans-nuclear-exports-riskybusiness/.

Culpepper, Pepper D. 2011. Quiet Politics and Business Power: Corporate Control in Europe and Japan. New York: Cambridge University Press.

Daily Sabah. 2016. "Toyota Moves Automobile Production to Turkey." Daily Sabah, 7 June. https://www.dailysabah.com/automotive/2016/06/07/toyota-movesautomobile-production-to-turkey.

Dallmayr, Fred, M. Akif Kayapınar, and Ismail Yaylacı. 2014. "Introduction," in Civilizations and World Order, edited by Fred Dallmayr, M. Akif Kayapınar, and Ismail Yaylac1, xv-xxii. Lanham, MD: Lexington Books.

Davutoğlu, Ahmet. 2014a. "Foreword: Civilizational Revival in the Global Age," in Civilizations and World Order: Geopolitics and Cultural Differences, edited by Fred Dallmayr, M. Akif Kayapınar, and Ismail Yaylacı, vii-xii. Lanham, MD: Lexington Books. 
2014b. "The Formative Parameters of Civilizations: A Theoretical and Historical Framework," in Civilizations and World Order: Geopolitics and Cultural Differences, edited by Fred Dallmayr, M. Akif Kayapınar, and İsmail Yaylac1, 73-97. Lanham, MD: Lexington Books.

de Boer, John. 2005. "Before Oil: Japan and the Question of Israel/Palestine, 19171956." The Asia-Pacific Journal \Japan Focus 3, iss. 3 (March): 1-11.

DeWit, Andrew. 2014. “Japan's Renewable Power Prospects,” in Critical Issues in Contemporary Japan, edited by Jeff Kingston, 120-33. New York: Routledge.

. 2017. "Energy Transitions in Japan," in The Geopolitics of Global Energy: The New Cost of Plenty, edited by Timothy C. Lehmann, 183-203. Boulder, CO: Lynne Rienner Publishers, Inc.

Deudney, Daniel. 1996. "Ground Identity: Nature, Place, and Space in Nationalism," in The Return of Culture and Identity in IR Theory, edited by Yosef Lapid and Friedrich Kratochwil, 129-45. Boulder, CO: Lynne Rienner Publishers.

. 1999. "Environmental Security: A Critique," in Contested Grounds, edited by Daniel H. Deudney and Richard Anthony Matthew. Albany, NY: State University of New York Press.

Deutsch, Karl W., Sidney A. Burrell, Robert A. Kann, Maurice Lee, Jr., Martin Lichterman, Raymond E. Lindgren, Francis L. Loewenheim, and Richard W. Van Wagenen. 1957. Political Community and the North Atlantic Area. Princeton, NJ: Princeton University Press.

Donor Tracker. 2018. “Japan: Donor Profile.” Donor Tracker. Berlin, Germany: SEEK Development.

https://donortracker.org/sites/default/files/donor_pdfs/DonorTracker_profile_Japa n_0.pdf.

Dugan, Aleksandr. 1997. Osnovy geopolitiki: geopoliticheskoe budushchee Rossii [The fundamentals of geopolitics: the geopolitical future of Russia]. Moscow: Aktogeia.

2007. Geopolitika postmoderna. Vremena novych imperii; ocherki geopolitiki XXI veka [Geopolitics of Postmodernity. The Times of New Empires; Essays on the Geopolitics of the Twenty-First Century]. St. Petersburg: Amfora.

. 2013. "Geopolitics of Russia" (lecture). Delivered on 16 April at the Institute of International Relations, Athens, Greece. Video. https://www.youtube.com/watch?v=XUOSHO4hDgo. 
Economist. 2014. "Eclipsed by Apple: Japanese Electronics Firms." The Economist, 12 July, 57.

. 2015. "Winds of Change: Japanese Companies," The Economist, 6 June, 53.

EDMC. 2016. Survey of Energy and Economic Statistics, 2015. Tokyo: Energy Data and Modelling Center, Institute of Energy Economics, Japan. Cited and adapted in Andrew DeWit. 2017. "Energy Transitions in Japan," in The Geopolitics of Global Energy: The New Cost of Plenty, edited by Timothy C. Lehmann, 186. Boulder, CO: Lynne Rienner Publishers, Inc.

Edström, Bert. 2011. Japan and Human Security: The Derailing of a Foreign Policy Vision. Stockholm: Institute for Security and Development Policy.

Eich, Thomas. 2007. "Pan-Islam and 'Yellow Peril': Geo-Strategic Concepts in Salafi Writings Prior to World War I," in The Islamic Middle East and Japan, edited by Renée Worringer. 121-35. Princeton, NJ: Markus Wiener Publishers.

EIU. 2018. Democracy Index 2017. London: Economist Intelligence Unit.

Emont, Jon. 2017. “Japan Prefers Robot Bears to Foreign Nurses.” Foreign Policy, 1 March. foreignpolicy.com/2017/03/01/japan-prefers-robot-bears-to-foreignnurses/.

Enayat, Seyed Ebrahim. 1994. "Japan, Iran, and the Oil Business: A Case Study of Iran Japan Petrochemical Company (IJPC)." PhD diss., University of Stirling.

Engel, Pamela. 2015. "These Toyota Trucks are Popular with Terrorists - Here's Why." Business Insider, 7 October. www.businessinsider.com/why-isis-uses-toyotatrucks-2015-10.

Esenbel, Selçuk. 2011. Japan, Turkey and the World of Islam. Kent, UK: Global Oriental.

e-Stat. 2018. "Tōkei de miru nihon" [Statistics of Japan]. e-Stat, Portal Site of Official Statistics of Japan. https://www.e-stat.go.jp/.

Fackler, Martin. 2015. "Abe is Said to Have Plans to Revise Pacific Charter." New York Times, 5 February: A9.

Fahey, Rob. 2017. "The End of the Iron Triangle and What It Means for Japanese Politics," Japan Forward, 1 March. https://japan-forward.com/the-end-of-theiron-triangle-and-what-it-means-for-japanese-politics/. 
Faiola, Anthony, and Dafna Linzer. 2006. "Japan Wary of Plan for Sanctions Against Iran: U.S. Ally Feels Tug of Financial, Energy Ties.” Washington Post, 13 June: A14.

Fan, C. Simon. 2016. Culture, Institution, and Development in China. New York: Routledge.

Feasel, Edward M. 2015. Japan's Aid: Lessons for Economic Growth, Development and Political Economy. New York: Routledge.

Ferdinand, Peter. 2016. "Westward Ho - the China Dream and 'One Belt, One Road': Chinese Foreign Policy Under Xi Jinping.” International Affairs 92: no. 4 (July): 941-57.

Fickling, David. 2017. "Saudi-Qatar's True Battleground is Asia.” Bloomberg Gladfly, 6 June. https://www.bloomberg.com/gadfly/articles/2017-06-06/saudi-qatar-s-truebattleground-is-asia.

Financial Tribune. 2016. "Japan Automakers Risk Losing Iranian Market Share.” Financial Tribute, 18 August. https://financialtribune.com/articles/auto/47839/japan-automakers-risk-losingiranian-market-share.

Finlan, Alastair. 2015. Interview with Pamela Engel. "These Toyota Trucks are Popular with Terrorists - Here's Why." Business Insider, 7 October. www.businessinsider.com/why-isis-uses-toyota-trucks-2015-10.

Foreign Affairs. 2014. "What the Kremlin is Thinking." Foreign Affairs 93, iss. 4 (July).

Fouse, David. 2007. “Japan's 'Values-Oriented Diplomacy.” New York Times, 21 March. https://www.nytimes.com/2007/03/21/opinion/21iht-edfouse.4978402.html.

Frank, Andre Gunder. 1998. ReOrient: Global Economy in the Asian Age. Berkeley: University of California Press.

Fukuda Mitsuru. 2016. "Anzen hoshō hōsei wo meguru: nihonjin no sensōkan to anzen hoshō ishiki" [Concerning the Security Law: views of war and awareness of security among Japanese]. Nihon Hōgaku 82, no. 3 (December): 129-49.

Fukuda Tomoko. 2015. "Zainichi pakisutanjin imin no esunikku-bijinesu to ekkyō suru shinzoku" [The ethnic business of Pakistani immigrants to Japan and transborder relatives]. Mita shakai gaku [Mita journal of sociology], no. 20 (July): 38-51.

and Asazuma Yutaka. 2011. "Nihon o kiten to suru chūkosha saiyushutsu shisutemu ni kan suru jittai chōsa" [Factual survey of the used car re-exportation 
system originated in Japan]. Kaihatsuron shū [journal of development policy studies], no. 87 (March): 163-98.

Fukuyama, Francis. 2017. Interviewed by Rachel Martin. "Francis Fukuyama on Why Liberal Democracy is in Trouble." NPR, 4 April.

https://www.npr.org/2017/04/04/522554630/francis-fukuyama-on-why-liberaldemocracy-is-in-trouble.

Fuse Hiroshi. 2015. "Nihon no chūtō gaikō: dono kuni tomo hanaseru ritensei kashi higunji kōken wo" [Japan's Middle East diplomacy: the advantage of talking with any country as a nonmilitary contribution]. Mainichi Shimbun Ekonomisuto, 24 March: 34.

George, Alexander L., and Andrew Bennett. 2005. Case Studies and Theory Development in the Social Sciences. Cambridge, MA: Belfer Center for Science and International Affairs.

Gerring, John. 2012. Social Science Methodology: A Unified Framework. New York: Cambridge University Press.

Gladney, Dru C. 2003. "Islam in China: Accommodation or Separatism?" The China Quarterly, No. 174 (June), 451-467.

Goldman, Marshall I. 2010. Petrostate: Putin, Power, and the New Russia. New York: Oxford University Press.

Greimel, Hans. 2015. "Toyota Responds to U.S. Inquiry over Vehicles being Used by ISIS.” Automotive News, 7 October. www.autonews.com/article/20151007/GLOBAL/151009869/toyota-responds-tou.s.-inquiry-over-vehicles-being-used-by-isis.

Haddad, Mary Alice. 2012. Building Democracy in Japan. New York: Cambridge University Press.

Halloran, Richard. 1973. "Japanese Caution Israelis on Ties." The New York Times, 22 November: 17.

Hammond, Joseph. 2013. "Rebiya Kadeer.” The Diplomat, 25 October. https://thediplomat.com/2013/11/rebiya-kadeer/.

Harnisch, Sebastian. 2011. "Role Theory: Operationalization of Key Concepts." Role Theory in International Relations: Approaches and Analyses. Edited by Sebastian Harnisch, Cornelia Frank, and Hanns W. Maull. New York: Routledge, 7-15. 
, Cornelia Frank, and Hanns W. Maull. 2011. "Conclusion: Role Theory, Role Change, and the International Social Order." Role Theory in International Relations: Approaches and Analyses. Edited by Sebastian Harnisch, Cornelia Frank, and Hanns W. Maull. New York: Routledge, 252-61.

Hayes, Louis D. 2018. Introduction to Japanese Politics, $6^{\text {th }}$ ed. New York: Routledge.

Herman, Steve. 2015. "Rail Rivals China, Japan Compete for High-Speed Track in Asia." Voice of America, 22 April. https://www.voanews.com/a/rail-rivals-china-japancompete-for-high-speed-track-in-asia/2730173.html.

Hertzmark, Donald. 2016. "Indonesia's Gas Challenge.” The National Bureau of Asian Research. http://nbr.org/downloads/pdfs/eta/pes_2016_brief_indonesia.pdf.

Hickok, Michael Robert. 2000. “The Other End of the Silk Road: Japan's Eurasian Initiative," Central Asian Survey 19, no. 1: 17-39.

Hirata Keiko. 2016. "Role Theory and Japanese Security Policy.” In Domestic Role Contestation, Foreign Policy, and International Relations. Edited by Cristian Cantir and Juliet Kaarbo. New York: Routledge, 55-71.

Hirose Takao. 2015. "Nihon ha doko kara sekiyu wo katteiruka?" [From where is Japan buying crude oil?] The Huffington Post Japan, Ltd., 4 March.

http://www.huffingtonpost.jp/takao-hirose/oil-import_b_6796744.html.

Hisane Masaki. 2001. "Japan Ready to Lift Sanctions on India." Japan Times, 9 September. https://www.japantimes.co.jp/news/2001/09/09/national/japan-readyto-lift-sanctions-on-india/\#.WwskNPZFyP8.

Holsti, K. J. 1970. "National Role Conceptions in the Study of Foreign Policy." International Studies Quarterly 14, no. 3 (September): 233-309.

Horie Masanobu. 2016. "Kachikan gaikō to jindō shien no kishiru" [The contradiction between Japan's value oriented diplomacy and humanitarian assistance]. Jindō kenkyū jānaru [Journal of humanitarian studies] 5 (March): 150-67.

Horner, Daniel. 2012. "Strains Seen in Japan's Plutonium Policy,” Arms Control Association. http://www.armscontrol.org/act/2012_11/Strains-Seen-in-JapansPlutonium-Policy.

Hosaka Shūji. 2013/2014. "Nihon, chūtō, sekiyu: 40nenmae to 10nenmae to 60nenmae" [Japan, the Middle East, and oil: 40 years ago, 10 years ago, and 60 years ago]. Chūtō Kyōryoku Sentā Nyūsu [Japan cooperation center for the Middle East news] (December/January): 66-72. 
Hoshiro Hiroyuki. 2007. "Postwar Japanese and Southeast Asian History - A new Viewpoint." Gateway to Asian Studies, Research and Information Center for Asian Studies, the University of Tokyo, 7 May. https://ricas.ioc.utokyo.ac.jp/asj/eng/html/ess018.html.

Hoshi Masamichi. 2017. "Autos, Not iPhones, Seen Driving Growth for Electronics Makers," Asia Nikkei Review, 9 September. https://asia.nikkei.com/Markets/Tokyo-Market/Autos-not-iPhones-seen-drivinggrowth-for-electronics-makers.

Hosoya Yuichi. 2014. "Japan's Two Strategies for East Asia: The Evolution of Japan's Diplomatic Strategy," Asia-Pacific Review 20, no. 2: 146-56.

Howell, Kerry E. 2013. An Introduction to the Philosophy of Methodology. Thousand Oaks, CA: SAGE Publications.

Huang, Kristin. 2017. "Why China's Bid to Sell High-Speed Rail Technology Overseas is Losing Steam." South China Morning Post, 2 April. http://www.scmp.com/news/china/diplomacy-defence/article/2084176/whychinas-bid-sell-high-speed-rail-technology-overseas.

Huntington, Samuel P. 1991. The Third Wave: Democratization in the Late Twentieth Century. Norman, OK: University of Oklahoma Press. . 1996. The Clash of Civilizations and the Remaking of World Order. New York: Touchstone.

IEA. 2016. Energy Policies of IEA Countries - Japan: 2016 Review. Paris: International Energy Agency.

IGU. 2016. World LNG Report. Barcelona, Spain: International Gas Union. . 2017. World LNG Report. Barcelona, Spain: International Gas Union.

ISSP. 1999. International Social Survey Program: Role of Government III. Ann Arbor, MI: Inter-University Consortium for Political and Social Research.

Itagaki Yūzō 2004. "Nihon shakai no isurāmu rikai wo saikentō suru" [A reexamination of Japanese society's comprehension of Islam], in Tami to kami to kamigami to: isurāmu, amerika, nihon wo yоти [People and God and gods: readings on Islam, America, and Japan], edited by Kwansei Gakuin University Research Center for Christianity and Culture, 233-74. Nishinomiya City, Hyogo Prefecture, Japan: Kwansei Gakuin University Press. 
Ito Masami. 2012. "LDP Returns with All Its Old Baggage.” Japan Times, 25 December. http://www.japantimes.co.jp/news/2012/12/25/reference/ldp-returns-with-all-itsold-baggage/\#.WQtOR6KzmQc.

Jaipragas, Bhavan. 2017. "Does China Have the Inside Track in Race with Japan for Singapore-Malaysia High-Speed Rail Contract?" The Week in Asia, 1 October. http://www.scmp.com/week-asia/article/2113440/does-china-have-inside-trackrace-japan-singapore-malaysia-high-speed-rail.

Japan Customs. 2017. Bōeki tōkei [trade statistics]. Tokyo: Customs and Tariff Bureau, Japan Ministry of Finance. www.customs.go.jp/toukei/.

Japan News. 2016. “Japan's Energy at Crossroads: Exports Give Hope to Nuclear Industry." Japan News, 3 February: 3.

Japan Times. 2016. "Former Japanese Leader Hatoyama to Buck Precedent, Join Advisory Panel of China-Led AIIB," 26 June. http://www.japantimes.co.jp/news/2016/06/26/business/economybusiness/former-japanese-leader-hatoyama-to-buck-precedent-join-advisorypanel-of-china-led-aiib/\#.WQnj7qKzmQc.

JBIC. 2007. "The Growing Importance of Islamic Finance." JBIC Today (July). Tokyo: Japan Bank for International Cooperation.

JETRO. 2014. "Japanese Trade and Investment Statistics," Japan External Trade Organization. http://www.jetro.go.jp/en/reports/statistics.html.

JICA. 2012. Japan Center. Tokyo: Japan International Cooperation Agency. Pamphlet. . 2017. "Enshakkan kyōyo jōkenhyō" [Conditions Charts for Yen Loan Provisions]. Tokyo: Japan International Cooperation Agency, 16 October. https://www.jica.go.jp/activities/schemes/finance_co/about/standard/ku57pq0000 22uhni-att/20171016.pdf.

JIIA. 2017. Chūtō jōsei: shinchiiki chitsujo [Middle East state of affairs: a new regional order]. Tokyo: Nihon kokusai mondai kenkyūsho [Japan Institute of International Affairs].

JNTO. 2017. Tōkei dēta (hōnichi gaikokujin - shukkoku nihonjin) [Statistical Data (Foreign Visitors to Japan and Exiting Japanese]. Tokyo: Japan National Tourism Organization. https://www.jnto.go.jp/jpn/statistics/visitor_trends/.

JOGMEC. 2016. Sekai no sekitan jijō (2015 nendo chūkan hōkoku) [World Coal Status (Fiscal 2015 Interim Report)]. Tokyo: Japan Oil, Gas and Metals National Corporation, 2 March. http://www.jogmec.go.jp/content/300306139.pdf. 
Jones, Bruce, and David Steven. 2015. The Risk Pivot: Great Powers, International Security, and the Energy Revolution. Washington, D.C.: The Brookings Institution.

Kafura, Craig. 2016. "The Iran Deal and the US-Japan Alliance.” The Diplomat, 1 March. https://thediplomat.com/2016/03/the-iran-deal-and-the-us-japan-alliance/.

Kamata Tōji. 2009. Myth and Deity in Japan. Translated by Gaynor Sekimori. Tokyo: Japan Publishing Industry Foundation for Culture.

Kaplan, Robert. 2010. "The Geography of Chinese Power: How Far Will China Reach on Land and at Sea?" Foreign Affairs 89, No. 3: 22-41.

Karman, Tawakkol. 2014. "Unchaining the Potential of Women Worldwide: An Interview with Nobel Laureate Tawakkol Karman." Nippon.com, 14 October. https://www.nippon.com/en/people/e00070/.

Katzenstein, Peter J. 1996. Cultural Norms and National Security: Police and Military in Postwar Japan. Ithaca, NY: Cornell University Press. . 1997. "Introduction: Asian Regionalism in Comparative Perspective," In Network Power: Japan and Asia, Edited by Peter J. Katzenstein and Takashi Shiraishi. Ithaca, NY: Cornell University Press, 1-44.

Kawaguchi Yoriko. 2004. "Adding a New Dimension: Central Asia plus Japan” (speech). Delivered on 26 August at Tashkent, Uzbekistan. Ministry of Foreign Affairs. Transcript. http://www.mofa.go.jp/mofaj/press/enzetsu/16/ekw_0826.html (Japanese).

Kawato Akio. 2008. "What is Japan Up to in Central Asia?” In Japan's Silk Road Diplomacy: Paving the Road Ahead, edited by Christopher Len, Uyama Tomohiko, and Hirose Tetsuya. Washington, D.C.: Central Asia-Caucasus Institute \& Silk Road Studies Program, 15-29.

Keidanren. 2012. "TPP o teko to suru keizai renkei no sokushin ni mukete: ikkoku mo hayai TPP kōshō sanka no eidan o mitomeru" [TPP as a lever towards the promotion of economic cooperation: requesting an immediate resolution on TPP participation negotiations]. Nihon keizai dantai rengōkai [Japan Business Federation], 11 June. http://www.keidanren.or.jp/policy/2012/042.html.

Kennedy, Devereaux. 2012. "Constructing the Geo-Culture and Strengthening the Core," Critical Sociology 38, no. 6: 902-07. 
Khamenei, Ali. 2014. “Enemies' Main Problem is Iran's Progress,” Nuclear Issue, 27 November. http://english.khamenei.ir/Opinions/tnuclear.

. 2017. In Hafezi, Parisa, "Supreme Leader Khamenei says U.S. is Iran's 'Number One Enemy." Reuters, 2 November. https://www.reuters.com/article/usiran-usa/supreme-leader-khamenei-says-u-s-is-irans-number-one-enemyidUSKBN1D211H.

Kihara Jitsurō. 2009. Isuramu NOW [Islam NOW]. Kumamoto City, Kumamoto Prefecture: Kumamoto Nichinichi Shimbunsha.

Kingston, Jeff. 2014. "Demographic Dilemmas, Women and Immigration," Critical Issues in Contemporary Japan, edited by Jeff Kingston, 189-200. New York: Routledge.

Kishida Fumio. 2013a. “"Paresuchina kaihatsu no tame no higashi ajia kyōryoku sokushin kaigō (CEAPAD)' daiikkai kaigō kaikai resepushon niokeru daijin no bōtō supīchi" ['Conference on Cooperation among East Asian Countries for Palestinian Development (CEAPAD)' Cabinet Minister's Opening Address at the $1^{\text {st }}$ Conference Opening Reception]. Transcript. Tokyo: Ministry of Foreign Affairs. www.mofa.go.jp/mofaj/area/plo/pdfs/ceapad_gaiyo_01.pdf (Japanese)

. 2013b. "Iran no kaku mondai (EU3+3 to iran to no gōi)" [The Iranian nuclear issue (An Agreement between the EU3+3 and Iran)]. Press release statement by the Minister of Foreign Affairs. Tokyo: MOFA, 24 November. https://www.mofa.go.jp/mofaj/press/page4_000292.html (Japanese).

. 2015. "3-Pillar Foreign Policy in Response to the Terrorist Incident Regarding the Murder of Japanese." Press Release by Minister of Foreign Affairs on February 17. www.mofa.go.jp/mofaj/press/release/press3_000074.html (Japanese).

Kissinger, Henry. 2014. World Order: Reflections on the Character of Nations and the Course of History. New York: Penguin Group.

Koizumi Junichirō. 2001. "The International Symposium on Human Security” (speech). Delivered on 15 December in Tokyo. Ministry of Foreign Affairs. Transcript. http://www.mofa.go.jp/mofaj/gaiko/bluebook/2002/gaikou/html/siryou/sr_02_16.

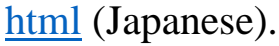

. 2002. "Japan and ASEAN in East Asia - A Sincere and Open Partnership" (speech). Delivered on 14 January in Singapore. Prime Minister of Japan and His Cabinet. Transcript. http://japan.kantei.go.jp/koizumispeech/2002/01/14speech_e.html (English). 
Komura Akiko. 2015. Nihon to isurāmu ga deau toki: sono rekishi to kanōsei [When Japan and Islam meet: the history and possibilities]. Tokyo: Gendai Shokan.

Kondō Takafumi. 2014. "Pakisutan ni okeru kaku kaihatsu no tenkai to yukue: gempatsu jiko hōdō ga motarashita mono" [Progress and outcome of Pakistan's nuclear developments: Brought about by nuclear accident], in Ajia no "kaku" to watashitachi: Fukushima wo mitsumenagara ["Nuclear" Asia and us: While considering Fukushima]. Edited by Takahashi Nobuo. Tokyo: Keio University Press, 179-99.

Kōno Tarō. 2017. "Evolving International Partnerships in the Middle East" (speech). Delivered on 9 December at the IISS Manama Dialogue in Bahrain. IISS Manama Dialogue. Transcript. https://www.iiss.org/en/events/manama-dialoguetest/archive/manama-dialogue-2017-c364/plenary3-dca2/taro-kono-bc6b (English).

. 2018. "Extraordinary Press Conference by Foreign Minister Taro Kono." Conducted on 17 February in Munich. Ministry of Foreign Affairs. Transcript. http://www.mofa.go.jp/mofaj/press/kaiken/kaiken4_000652.html (Japanese).

Koschmann, J. Victor. 1997. “Asianism's Ambivalent Legacy,” in Network Power: Japan and Asia, edited by Peter J. Katzenstein and Takashi Shiraishi, 83-110. Ithaca, NY: Cornell University Press.

Kotkin, Stephen. 2016. "Russia's Perpetual Geopolitics - Putin Returns to the Historical Pattern." Foreign Affairs 95, iss. 3 (May).

Koyama Ken. 2013. “Japan's Post-Fukushima Energy Policy Challenges,” Asian Economic Policy Review 8: 274-93.

Krämer, Hans Martin. 2014. "Pan-Asianism's Religious Undercurrents: The Reception of Islam and Translation of the Qur'ān in Twentieth-Century Japan," The Journal of Asian Studies 73, iss. 3 (August): 619-40.

Kratochwil, Friedrich. 2008. "Constructivism: What It Is (Not) and How It Matters," in Approaches and Methodologies in the Social Sciences, edited by Donatella Della Porta and Michael Keating, 80-98. New York: Cambridge University Press.

Kubicek, Paul. 2015. Political Islam and Democracy in the Muslim World. Boulder, CO: Lynne Rienner Publishers.

Kubota Seiichi. 2009. Kokusai kyōryoku no genba kara mita ajia to nihon: keizai gijutsu $k \bar{o} r y \bar{u}$ no 50nen [Asia and Japan as seen from the perspective of international cooperation: 50 years of economics, technology, and exchange]. Tokyo: 3A Network. 
Kuroda Yasumasa. 2005. The Core of Japanese Democracy. New York: Palgrave Macmillan.

Kuznetsov, Vyacheslav. 2003. Geokul'tura: osnovy geokul'turnoj dinamiki bezopasnosti $v$ mire XXI : kul'tura-set' [Geoculture: principles of geocultural dynamics of security in world XXI: culture-network]. Moscow: Kniga i Biznes.

Kyodo News International. 2013. "Abe Vows to Promote Japan Nuclear Infrastructure Exports to Mideast." Kyodo News International, 2 May.

LaFeber, Walter. 1997. The Clash. New York: W.W. Norton \& Company.

Lakhera, Mohan L. 2008. Japanese FDI Flows in Asia: Perspectives and Challenges. New York: Palgrave MacMillan.

Laruelle, Marlène. 2008. Russian Eurasianism: An Ideology of Empire. Baltimore, MD: Johns Hopkins University Press.

Laursen, Finn. 2010. "Regional Integration: Some Introductory Reflections," in Comparative Regional Integration: Europe and Beyond, edited by Finn Laursen. Farnham, Surrey, UK: Ashgate, 3-20.

The Leader-Post. 1979. "105 Iranian Firms Said Controlled by Royal Family.” The Leader-Post (Regina, SK) 22 January: 41.

Lee, Min Jeong, Yuko Takeo, and Toshiro Hasegawa. 2017. "Tokyo Seeks Return to Glory Days with Piece of Saudi Aramco IP.” Bloomberg, 17 July. https://www.bloomberg.com/news/articles/2017-07-17/tokyo-seeks-return-toglory-days-with-piece-of-saudi-aramco-ipo.

Lei Wan. 2010/2012. "The Chinese Islamic 'Goodwill Mission to the Middle East' During the Anti-Japanese War.” Journal of Interdisciplinary Studies 15, no. 29: 133-70.

Lewis, Martin W., and Kären E. Wigen. 1997. The Myth of Continents. Berkeley, CA: University of California Press.

Li Mingjiang and Shoon Ming Hui. 2015. "China’s Changing Responses to US Regional Policy in Asia Pacific," in United States Engagement in the Asia Pacific: Perspectives from Asia, edited by Yoichiro Sato and Tan See Seng, 37-60. Amherst, NY: Cambria Press.

Liem, Vu Duc. 2011. "Japanese Military Involvement in Ayutthaya, 1600 - 1630." Bangkok: Asian Research Center for Migration, Chulalongkorn University. 
http://arcmthailand.com/documents/documentcenter/JAPANESE\%20MILITARY \%20INVOLVEMENT\%20IN\%20AYUTTHAYA,\%201600\%20-\%201630.pdf.

Licklider, Roy. 1988. "The Power of Oil: The Arab Oil Weapon and the Netherlands, the United Kingdom, Canada, Japan, and the United States," International Studies Quarterly 32, no. 2: 205-26.

Luttrell, Sam. 2015. "Resource Nationalism: Old Problem, New Solutions." Arbitration and Dispute Resolution in the Resources Sector. Edited by Moens, Gabriël A., and Philip Evans. New York: Springer Cham, 197-230.

Ma Tieying. 2016. "Japan: Rising Direct Investment in Southeast Asia." DBS Group Research, 18 March.

MacArthur, Douglas. 1964. Reminiscences. New York: McGraw-Hill.

Mahan, Alfred Thayer. 1900. The Problem of Asia and Its Effect upon International Policies. London: Sampson Low, Marston \& Co., Ltd.

Mahr, Krista. 2014. "Japan and India Bolster Trade and Defense Ties," Time 27 January. http://time.com/1794/japan-and-india-bolster-trade-and-defense-ties/.

Mamun, Shohel. 2017. "Dhaka-Chittagong High-Speed Rail Link Likely by 2022." Dhaka Tribune, 2 November. www.dhakatribune.com/bangladesh/development/2017/11/02/high-speed-raillink-2022/.

Masao Kunihiro. 1984. “The 'Japan as Number One’ Syndrome,” Japan Echo 11, no. 3: 44-51.

Mason, Mark. 1999. "The Origins and Evolution of Japanese Direct Investment in East Asia," in Japanese Multinationals in Asia: Regional Operations in Comparative Perspective, edited by Dennis J. Encarnation, 17-45.

Mathur, Arpita. 2012. India-Japan Relations: Drivers, Trends and Prospects. Singapore: S. Rajaratnam School of International Studies, RSIS Monograph no. 23.

Mattioli, Dana, Russell Gold, and Jacquie McNish. 2018. "Westinghouse's Assets Find Buyer." Wall Street Journal, 5 January, B1-B2.

McCormack, Gavan. 2007. Client State: Japan in the American Embrace. New York: Verso.

McGlynn, John. 2009. "Japan, Israeli Settlements, and the Future of a Palestinian State." The Asia-Pacific Journal $\backslash$ Japan Focus 7, iss. 52, no. 1 (December): 1-8. 
Merati, Simona E. 2017. Muslims in Putin's Russia. Cham, Switzerland: Palgrave Macmillan.

Mesbahi, Mohiaddin. 2010. "Eurasia between Russia, Turkey, and Iran," in Key Players and Regional Dynamics in Eurasia, edited by Maria Raquel Freire and Roger E. Kanet, 164-92. New York: Palgrave MacMillan, 2010.

Métraux, Daniel A. 2007. "Religion, Politics, and Constitutional Reform in Japan," Southeast Review of Asian Studies 29: 157-72.

METI. 2015. Heisei 26nen enerugī hakusho [energy white paper, 2014]. Tokyo: Japan Ministry of Economy, Trade, and Industry. http://www.enecho.meti.go.jp/about/whitepaper/2015pdf/.

Middlebrooks, William C., Jr. 2008. Beyond Pacifism: Why Japan Must Become a 'Normal' Nation. Westport, CT: Praeger Security International.

Midford, Paul. 2011. Rethinking Japanese Public Opinion and Security. Stanford, CA: Standford University Press.

Miller, J. Berkshire. 2017. "Qatar Crisis Presents Both Threat and Opportunity for Japan.” Nikkei Asian Review, 19 June. https://asia.nikkei.com/Viewpoints/J.Berkshire-Miller/Qatar-crisis-presents-both-threat-and-opportunity-for-Japan.

Misawa Nobuo. 2011. "Shintoism and Islam in Interwar Japan: How Did the Japanese Come to Believe in Islam?" Orient 46: 119-39.

Miyagi Taizo. 2018. Japan's Quest for Stability in Southeast Asia. Translated by Hanabusa Midori. New York: Routledge.

Miyata Osamu. 2005. Isuramu chōkagekiha [Islamic extremists]. Tokyo: Kōdansha. . 2013. Isuramu no hito ha naze nihon wo sonkei surunoka [Why do Muslims respect Japan?]. Tokyo: Shinchōsha.

. 2014a. "Nihon to isuramu sekai wo tsunagu: seishinteki kachi, tekunorojī, nihon no shien" [Connecting Japan and the Muslim world: spiritual values, technology, and Japan's support]. Chütō kyōryoku sentā nyūsu [Japan Cooperation Center for the Middle East News] (June/July): 61-66.

. 2014b. Nihonjin to shite shitte okitai: sekai wo ugokasu gendai isuramu [What Japanese should know: contemporary Islam moves the world]. Tokyo: Tokuma Shoten. 
2015. Amerika ha isuramukoku ni katenai [America cannot defeat ISIS].

Tokyo: PHP Kenkyūsho [Institute].

, Nishihara Masashi, and Nagasawa Eiji. 2015. "Zadankai: hitojichi jiken ga nokoshita kadai" [Roundtable discussion: issues remaining from the hostage crisis]. Asahi Shimbun, 3 February: 13.

. 2016. "Chūtō - isuramu chiiki ha nihon wo shinrai taibei ippentō no gaikō seisaku ha kiken" [The danger to Japan's trust in the Middle East and Muslim world due to a foreign policy devoted to the U.S.]. Shüchū [Focus], October: 5654 (reverse order).

. 2017. Isuramu yuiitsu no kibō no kuni: nihon [Islam's only hope: Japan]. Tokyo: PHP Kenkyūsho [Institute].

Mizokami, Kyle. 2016. "Sorry, China: Why the Japanese Navy is the Best in Asia." The National Interest, 16 October. http://nationalinterest.org/blog/the-buzz/sorrychina-why-the-japanese-navy-the-best-asia-18056.

Mochizuki Takashi. 2018. "After Sony Resurgence, CEO to Step Down." The Wall Street Journal, 3-4 February, B2.

MOFA. 1991. Japan's Official Development Assistance 1990. Tokyo: Association for Promotion of International Cooperation.

1992. Japan's Official Development Assistance Charter. Tokyo: Ministry of Foreign Affairs of Japan. www.mofa.go.jp/policy/oda/summary/1999/ref1.html (English).

www.mofa.go.jp/mofaj/gaiko/oda/shiryo/hakusyo/04_hakusho/ODA2004/html/ho npen/hp203020000.htm (Japanese).

. 1997. Japan's ODA Annual Report (Summary) 1996. Tokyo: Ministry of Foreign Affairs of Japan. www.mofa.go.jp/policy/oda/summary/1996/c_6.html.

. 1998. "Comments by the Chief Cabinet Secretary on Measures in Response to Nuclear Testing Conducted by Pakistan. Press Releases (Statements). Tokyo: Ministry of Foreign Affairs of Japan, 29 May. https://www.mofa.go.jp/announce/announce/1998/5/p_measure.html.

. 2001. "Announcement by the Chief Cabinet Secretary on Discontinuation of Measures in Response to Nuclear Testing Conducted by India and Pakistan." Regioinal Affairs. Tokyo: Ministry of Foreign Affairs of Japan, 26 October. https://www.mofa.go.jp/region/asia-paci/india/announce0110.html. 
2003. Japan's Development Cooperation Charter. Tokyo: Ministry of Foreign Affairs of Japan. http://www.mofa.go.jp/policy/oda/reform/revision0308.pdf (English).

www.mofa.go.jp/mofaj/gaiko/oda/shiryo/hakusyo/04_hakusho/ODA2004/html/ho npen/hp203010000.htm (Japanese).

. 2013. "Conference on Cooperation among East Asian Countries for Palestinian Development (CEAPAD) (outline and evaluation)." Ministry of Foreign Affairs, 14 February. http://www.mofa.go.jp/mofaj/area/plo/ceapad_gaiyo_20130214.html (Japanese).

. 2015a. Jichi seifu tanjō no rekishi wo sasaeru: Mindanao no heiwa wo mezashite [Supporting the history of an autonomous government: toward peace in Mindanao]. Tokyo: Ministry of Foreign Affairs of Japan, 8 October. www.mofa.go.jp/mofaj/gaiko/oda/about/hanashi/page23_000642.html.

. 2015b. Japan's Official Development Assistance Charter. Tokyo: Ministry of Foreign Affairs of Japan. www.mofa.go.jp/files/000067701.pdf (English). www.mofa.go.jp/mofaj/gaiko/oda/files/000072774.pdf (Japanese).

2015c. Diplomatic Bluebook 2015. Tokyo: Ministry of Foreign Affairs, Japan.

. 2016a. Kaihatsu kyōryoku hakusho zuhyō [development cooperation white paper figures]. Tokyo: Ministry of Foreign Affairs of Japan. http://www.mofa.go.jp/mofaj/gaiko/oda/press/shiryo/page22 000322.html.

. 2016b. Diplomatic Bluebook 2016. Tokyo: Ministry of Foreign Affairs, Japan.

. 2017a. 'Nich-sauji bijon 2030' no sakusei keii ['Japan-Saudi vision 2030' framework]. Tokyo: Ministry of Foreign Affairs of Japan. www.meti.go.jp/press/2016/03/20170313006/20170313006-1.pdf.

. 2017b. Kaigai zairyū hōjin sū chōsa tōkei (H28.10.1 genzai) [Statistical survey on numbers of overseas Japanese residents, (at present, 1 October 2016)]. Tokyo: Ministry of Foreign Affairs of Japan. www.mofa.go.jp/mofaj/toko/page22_000043.html.

.2017c. Diplomatic Bluebook 2017. Tokyo: Ministry of Foreign Affairs, Japan.

MOFA Indonesia, ed. 1955. Final Communiqué of the Asian-African Conference of Bandung. Jakarta: Ministry of Foreign Affairs, Republic of Indonesia, 161-169.

Mogi Makoto. 2017. Manga de wakaru chiseigaku [Geopolitics understood through illustrations]. Tokyo: Ikeda Shoten. 
Mohammed, Arshad, and Andrew Quinn. 2012. "U.S. Exempts 11 States from Iran Sanctions; China, India Exposed," Reuters, March 20. https://www.reuters.com/article/us-iran-usa-sanctions-crude/u-s-exempts-11states-from-iran-sanctions-china-india-exposed-idUSBRE82J11M20120321.

Mohan, C. Raja. 2000. "India, Japan Unveil New Global Partnership.” The Hindu, 24 August: 1.

Montgomery, Scott L. 2010. The Powers That Be. Chicago: The University of Chicago Press.

Morikawa Masayuki. 2016. "Toward a Service-Oriented Country - From the Perspective of the Globalization of the Economy." Japan SPOTLIGHT (September / October): 32-35.

Morris-Suzuki, Tessa. 2009. "Asia Is One: Visions of Asian Community in Twenty-First Century Japan." Shadows of the Past: Of Okakura Tenshin and Pan-Asianism, edited by Brij Tankha, 158-70. Folkestone, Kent, UK: Global Oriental Ltd.

. 2012. "Post-War Warriors: Japanese Combatants in the Korean War." The Asia-Pacific Journal | Japan Focus 10, iss. 31, no. 1 (July): 1-19.

Morrow, Daniel, and Michael Carriere. 1999. "The Economic Impacts of the 1998 Sanctions on India and Pakistan." The Nonproliferation Review 6, no. 4 (Fall): 116.

Mukherjee, Kunal. 2010. “Is There a Distinct Style of Asian Democracy?” Journal of Asian and African Studies 45, No. 6: 684-94.

Murakami Takuya. 2014. "Areru chūtō: tsugi no hakkaten ha iran no kaku kaihatsu" [The stormy Middle East: Iran's nuclear developments as the next flashpoint]. Wedge 26, no. 11 (November): 42-44.

Nagasawa Eiji and Nukii Mari. 2015. "Recommendations for Japan's Middle East Policy," in The Middle East as a Global Strategic Challenge - Outlook in 2030 and Responses (FY2013-2014), edited by Nagasawa Eiji, 227-36. Tokyo: JIIA.

Naitō Masanori. 2015. Isuramu sensō: chūtō hōkai to ōbei no haiboku [Islamic war: the collapse of the Middle East and the West's defeat]. Tokyo: Shūeisha.

Nakajima Ikuo. 2015. Sekiyu to nihon: kunan to zasetu no shigen gaikōshi [Oil and Japan: the history of hardships and failures in resource diplomacy]. Tokyo: Shinchō Books. 
Nakata Kazuyoshi. 2015. "Nihon no sābisu yushutsu no tokuchō to kadai" [Characteristics and issues in Japan's service exports]. Chōsa to tenbō [Survey and outlook], no. 25 (September), Mitsubishi UFJ Research and Consulting: 1-18.

Nasr, Seyyed Hossein. 2002. The Heart of Islam. New York: HarperCollins.

Nasr, Seyyed Vali Reza. 2009. Forces of Fortune. New York: Free Press.

Nezir Akmeşe, Handan. 2007. "The Japanese Nation in Arms: A Role Model for Militarist Nationalism in the Ottoman Army, 1905-1914," in The Islamic Middle East and Japan, edited by Renée Worringer. 63-89. Princeton, NJ: Markus Wiener Publishers.

Nikkei. 2017. "Indonesia Car Demand Set to Weaken to Near 2014 Levels." Nikkei Asian Review: FT Confidential Report, 9 February. https://asia.nikkei.com/Features/FTConfidential-Research/Indonesian-car-demand-set-to-weaken-to-near-2014levels?page $=1$.

NTI. 2014. "Civilian HEU: Japan," Analysis. Washington, D.C.: Nuclear Threat Initiative, 23 April. http://www.nti.org/analysis/articles/civilian-heu-japan/.

Nukii Mari. 2014. "Japan-Iran Relations: From the Silk Road to Oil Tankers." Gulf Asia Research Bulletin, no. 7 (January): 18-20.

Nye, Joseph S., Jr. 2004. Soft Power: The Means to Success in World Politics. New York: Perseus Books Group.

Obe Mitsuru. 2015. "Japan Says China Wins Indonesia High-Speed Rail Contract," Wall Street Journal 29 September. https://www.wsj.com/articles/japan-says-chinawins-indonesia-rail-contract-1443537614.

Ogawa Tadashi. 2016. Indoneshia: isurāmu taikoku no henbō [Indonesia: the transfiguration of Islam's great power]. Tokyo: Shinchosha.

OICA. 2018. "Sales Statistics." International Organization of Motor Vehicle Manufacturers. www.oica.net/category/sales-statistics/.

Okakura Kakuzo (a.k.a. Okakura Tenshin). 1904. Ideals of the East. Mineola, NY: Dover Publications, Inc.

Parasie, Nicolas, and Margherita Stancati. 2017. "Car Makers Woo Millions of Saudi Women as Driving Ban Ends.” Wall Street Journal (online), 5 October. https://www.wsj.com/articles/car-makers-woo-millions-of-saudi-women-asdriving-ban-ends-1507201201. 
Paris, Costas. 2015. "Islamic Republic of Iran Shipping Lines Looking to Buy New Ships - Chairman." Dow Jones Newswires 7 October.

https://www.dowjones.com/scoops/islamic-republic-of-iran-shipping-lineslooking-to-buy-new-ships-chairman/.

Pattanaik, Smruti S. 2008. "Pakistan: The Post-Chagai Challenges," Strategic Analysis 22, no. 6: 883-902.

Pehlivantürk, Bahadır. 2016. "Turkey-Japan: Dialogue on Global Affairs," Perceptions XXI, no. 1 (Spring): 1-9.

Penn, Michael. 2007. "East Meets East: An Ottoman Mission in Meiji Japan," in The Islamic Middle East and Japan, edited by Renée Worringer, 33-62. Princeton, NJ: Markus Wiener Publishers.

Perlez, Jane. 2001. "U.S. Ready to End Sanctions on India to Build Alliance." New York Times, 27 August, A1.

Pesek, William. 2014. Japanization: What the World Can Learn from Japan's Lost Decades. Singapore: John Wiley \& Sons.

Petroleum Economist. 2004. "LNG Evolution \& Development Wall Chart," Petroleum Economist. http://www.energy.ca.gov/lng/documents/SIGNIFICANT_EVENTS_LNG_HIST ORY.PDF.

Pew. 2010. Global Attitudes Project. Washington, D.C.: Pew Research Center. http://assets.pewresearch.org/wp-content/uploads/sites/2/2010/06/Pew-GlobalAttitudes-Spring-2010-Report-June-17-11AM-EDT.pdf.

Preble, Christopher A. 2006. "Don't Count on Japan's Support for Sanctions." CATO Institute, 29 June. https://www.cato.org/publications/commentary/dont-countjapans-support-sanctions.

Pyle, Kenneth B. 2018. "Japan's Return to Great Power Politics: Abe's Restoration." Asia Policy 13, no. 2 (April): 69-90.

Qin Guoji. 2008. "The Thinking Way of Confucianism and the Rule of Law." Journal of Politics and Law 1, no. 1 (March): 68-75.

Rahman, Mizanur Md, and Lian Kwen Fee. 2011. "The Development of Migrant Entrepreneurship in Japan: Case of Bangladeshis.” Journal of International Migration and Integration 12, no. 3: 253-74. 
Reader, Ian. 1991. Religion in Contemporary Japan. Houndmills, Basingstoke, Hampshire, UK: Macmillan Press, Ltd.

, and George J. Tanabe, Jr. 1998. Practically Religious. Honolulu: University of Hawai'i Press.

Reed, Stanley. 2015. "Liquefied Natural Gas Makes Qatar an Energy Giant," The New York Times, 6 August, B1.

Resnik, Evan. 2015. "The Obama Rebalance and US Policy Towards China," in United States Engagement in the Asia Pacific: Perspectives from Asia, edited by Yoichiro and Tan See Seng, 11-36. Amherst, NY: Cambria Press.

Reuters. 2015. "Saudi's Bahri to Buy Five More Oil Tankers from Hyundai Heavy." Reuters, 1 July. https://www.reuters.com/article/bahri-shipping/saudis-bahri-tobuy-five-more-oil-tankers-from-hyundai-heavy-idUSL8N0ZH3GX20150701.

RIST. 2004. Nihon no sekiyu enerugii seisaku [Japan's Coal Energy Strategy]. Tōkai Village, Ibaraki Prefecture: Research Organization for Information Science and Technology. www.rist.or.jp/atomica/data/dat_detail.php?Title_No=01-09-02-01.

Roberts, Graeme. 2014. "Toyota to Build Compact SUVs in Turkey - Report.” Just Auto, 15 October. https://www.just-auto.com/news/toyota-to-build-compact-suvs-inturkey-report_id151357.aspx.

Rogin, Josh. 2017. "Trump Could Make Obama's Pivot to Asia a Reality.” The Washington Post, January 8. https://www.washingtonpost.com/opinions/globalopinions/trump-could-make-obamas-pivot-to-asia-a-reality/2017/01/08/a2f8313ad441-11e6-945a76f69a399dd5_story.html?noredirect=on\&utm_term=.d905837c3181.

Roser, Max, and Esteban Ortiz-Ospina. 2017. "Literacy," OurWorldInData.org. https://ourworldindata.org/literacy/.

Rozov, N.S. 2012. "Geopolitics, Geoeconomics, and Geoculture: The Interrelation of Dynamic Spheres in the History of Russia," Russian Social Science Review 53, No. 6 (November-December): 4-26.

Said, Edward W. 1979. Orientalism. New York: Vintage Books.

Sakai Keiko. 2010. "Islam, Muslims, Neighbors in Asia? The Transformation of Japan's Perceptions of Islam as Shown in Its Media," Islam in the Eyes of the West: Images and Realities in an Age of Terror, edited by Tareq Y. Ismael and Andrew Rippin, 125-47. New York: Routledge. 
2016. Utsurō chūtō, kawaru nihon 2012-2015 [Move to the Middle East, and Japan changes 2012-2015]. Tokyo: Misuzu Shōbō.

Sakurai Joji. 2017. "Who is Yuriko Koike, the Most Powerful Women in Japan?" The New Statesman 10 August.

http://www.newstatesman.com/culture/observations/2017/08/who-yuriko-koikemost-powerful-woman-japan.

Samuels, Gabriel. 2016. "Piece of Carved Wood Suggests Persian Taught Maths in Japan 1,000 Years Ago," Independent, 6 October.

http://www.independent.co.uk/news/world/asia/persian-maths-discovery-japancarved-wood-artefact-archaeologists-1000-years-a7347726.html.

Sankei. 2013. "Isuramu hon ga shuppan chūshi: arujeria jiken uke nikkei shimbun shuppan" [Current Algeria crisis results in Nikkei Shimbun cancelling the publication of Islam book], Sankei News, 17 March.

http://www.sankei.com/life/print/130317/lif1303170016-c.html.

Sasaki Shin. 2016. "Kyōto no daigaku kyōshi ga tero yōgisha, bangura seifu ga saijūyō tehai," [A Kyoto University teacher is terror suspect, Bangladesh government says most wanted], Wedge, $20 \mathrm{July.} \mathrm{http://wedge.ismedia.jp/articles/-/7347.}$

Sato Yoichiro. 2008. “Three Norms of Collective Defense and Japan's Overseas Troop Disptaches." In Norms, Interests, and Power in Japanese Foreign Policy, edited by Sato Yoichiro and Hirata Keiko, 93-108. New York: Palgrave Macmillan.

, and Asano Masahiko. 2008. "Humanitarian and Democratic Norms in Japan's ODA Distributions," in Norms, Interests, and Power in Japanese Foreign Policy, edited by Sato Yoichiro and Hirata Keiko, 111-27. New York: Palgrave Macmillan.

Sawabe Yūji. 2017. Zukai: ichiban yasashii chiseigaku no hon [Diagrams: the most comprehensible book on geopolitics]. Tokyo: Saizusha.

Sawamura Nobuhide. 2004. 'Japan's Philosophy of Self-Help Efforts in International Development Cooperation: Does It Work in Africa?” Journal of International Cooperation in Education 7, no. 1: 27-40.

Scalapino, Robert. 2002. "Japan's Economic Route to Power," in Comparative Foreign Policy: Adaptation Strategies of the Great and Emerging Powers, edited by Steven Hook, 92-117. Upper Saddle River, NJ: Pearson Education.

Schmetzer, Uli. 2001. "Japanese Artist Seeks to Save Afghanistan's Buddha Statues." Chicago Tribune, 7 March. http://articles.chicagotribune.com/2001-0307/news/0103070232_1_statues-mullah-mohammed-omar-taliban. 
Scholze, Marko. 2010. "Between the Worlds" Tuareg as Entrepreneurs in Tourism," in Tuareg Society within a Globalized World, edited by Fischer, Anja, and Ines Kohl, 171-89. New York: Tauris Academic Studies.

Shaath, Nabil. 2018. Quoted in "Paresuchina jichi seifu, 'nihon ha paresuchina kokka no shōnin ni mukau."” ParsToday, 4 February. http://parstoday.com/ja/news/japani39617.

Shambaugh, David. 2015. "China's Soft-Power Push - The Search for Respect," Foreign Affairs 94, iss. 4 (1 July).

Shaw-Smith, Peter. 2016. "Islamic Republic of Iran Shipping Line Orders 10 Ships from South Korea.” Fairplay, 12 December. https://fairplay.ihs.com/commerce/article/4279231/islamic-republic-of-iranshipping-line-orders-10-ships-from-south-korea.

Shiroishi Takashi. A conversation among Yabukawa Mitoji, Shiroishi Takashi, and Iizuka Keiko. "Taidan: nihon ha ajia to no paipu yaku wo ninae" [Conversation: Japan must be the mediator for Asia]. Gaikō [Diplomacy] 42 (March/April): 2131.

Shugiin. 2008. "Kokkai: kokusai terorizumu no bōshi oyobi wagakuni no kyōryoku shien katsudō narabi ni iraku jindō fukkō shien katsudō nado ni kansuru tokubetsu iinkai dai 3 gō" [Third ad hoc committee concerning prevention of international terrorism, and our country's cooperation assistance actions and Iraq humanitarian reconstruction assistance actions, et cetera]. Transcript of minutes. The House of Representatives, Japan, 17 October. http://www.shugiin.go.jp/internet/itdb_kaigirokua.nsf/html/kaigirokua/013317020 081017003.htm.

Simpfendorfer, Ben. 2014. The Rise of the New East. New York: Palgrave MacMillan.

Singh, Khushwant. 1979. "Pakistan, India and the Bomb.” New York Times, 1 July: E21.

Smith, Sheila A. 2012. “Japan's Dilemma over Iran Sanctions.” The Atlantic, 1 February. https://www.theatlantic.com/international/archive/2012/02/japans-dilemma-overiran-sanctions/252337/.

. 2014. Japan's New Politics and the U.S.-Japan Alliance. New York: Council on Foreign Relations.

Söderberg, Marie. 1996. The Business of Japanese Foreign Aid: Five Case Studies from Asia. London: Routledge. 
. 2015. "Myanmar: The Last Frontier for Japanese Official Development Assistance (ODA) to Southeast Asia," in Japan Viewed from Interdisciplinary Perspectives, edited by Sugita Yoneyuki, 149-67. Lanham, MD: Lexington Books.

. 2017. "Global Change: Japan's Role in the Making of a New Aid Architecture," in Japanese Development Cooperation: The Making of an Aid Architecture Pivoting to Asia, edited by André Asplund and Marie Söderberg, 118. New York: Routledge.

Spitzer, Kirk. 2015. "Why Japan Lacks Sympathy for the Hostage Held by ISIS." Time, 23 January. time.com/3680492/japan-isis-hostages/.

State Council. 2015. "Full Text: Action Plan on the Belt and Road Initiative," The State Council, The People's Republic of China, 30 March.

http://english.gov.cn/archive/publications/2015/03/30/content_281475080249035. $\underline{\mathrm{htm}}$.

Stein, J.G. 1982. "Alice in Wonderland: The North Atlantic Alliance and the Arab-Israeli Dispute," in The Middle East and the Western Alliance, edited by S.L. Spiegel, 49-81. London: George Allen and Unwin.

Sternberg, Joseph C. 2018. “Amid an Investment Bust, Britain May Be Turning Japanese." The Wall Street Journal 2 February, A15.

Stokes, Bruce. 2015. "How Asia-Pacific Publics See Each Other and Their National Leaders: Japan Viewed Most Favorably, No Leader Enjoys Majority Support." Pew Research Center (September).

Sudō Shigeru. 2014. Nihon no sekiyu ha daijōbu nanoka? Sekiyu supurai chēn no sai kenshō [Is Japan's oil alright? A review of the oil supply chain]. Tokyo: Dōyūkan.

Sugawara Izuru. 2015. "Imaya 'nihon to isuramu-tero ha muen' to iu omoikomi ha kiken de aru: IS ni yoru nihonjin satsugai jiken ga tsukitsukeru mono" [The peril at present is thinking 'Japan and Islamic terror are unrelated': the execution of Japanese by IS is thrust upon us]. Shūkyō Mondai [Problems in religion] 10: 4453.

Sugiyama Kazuo. 2008. "Daiichiji oiru shokku wo kaiko suru" [A look back at the first oil crisis]. Kikan Kokusai bōeki to tōshi [International Trade and Investment Quarterly], no. 71 (Spring): 1-15.

Summers, Tim. 2015. “China's 'New Silk Roads': Sub-National Regions and Networks of Global Political Economy." Third World Quarterly 37, no. 9: 1628-43. 
Sun, Irene Yuan. 2017. The New Factory of the World. Boston: Harvard Business Review Press.

Szpilman, Christopher W., and Sven Saaler. 2011. Pan-Asianism as an Ideal of Asian Identity and Solidarity, 1850-Present. The Asia-Pacific Journal 9, iss. 17, no. 1 [April]: 1-28.

Tahara Kazuhiko. 2009. "Nihon hōseika no isurāmu kinyū torihiki" [Islamic finance dealing under Japanese law]. Isurāmu sekai kenkyū [Kyoto Bulletin of Islamic Area Studies] 2, no. 2 (March): 188-97.

Takahashi Kazuo. 2013. Nihonkei kachikan gaikō no kōsō (The framwork for Japanesestyle values-based diplomacy). Sekai heiwa kenkyū, no. 197 (Spring): 2-11.

Takahashi Motoki and Owa Masumi. 2017. "The Peculiarities of Japan's ODA and the Implications for African Development," in Japanese Development Cooperation: The Making of an Aid Architecture Pivoting to Asia, edited by André Asplund and Marie Söderberg, 19-40. New York: Routledge.

Takasu Yukio. 2000. "Statement by Director-General Yukio Takasu at the International Conference on Human Security in a Globalized World" (speech). Delivered on 8 May at Ulan-Bator, Mongolia. Ministry of Foreign Affairs. Transcript. http://www.mofa.go.jp/policy/human_secu/speech0005.html (English).

Takeyama Eitaro, Fujisaki Mari, and Watanabe Junki. 2017. "Japan-Saudi Ties Strengthen After King Salman's Visit.” The Asahi Shimbun, 1 April. www.asahi.com/ajw/articles/AJ201704010009.html.

Tan, Danny. 2017. "2017 to be a Challenging Year for the Malaysian Auto Industry, Flat Growth Expected - Saturation Point?” Paultan.org, 19 January. https://paultan.org/2017/01/19/2017-to-be-a-challenging-year-for-the-malaysianauto-industry-flat-growth-expected-saturation-point/.

Tanada Hirofumi. 2013. "Sekai to nihon no musurimu jinkō 2011 nen" [Muslim population in the world and Japan], Ningen kagaku kenkyu [Journal of Human Science Research] 26, no. 1, 29-39.

Tanaka Ippei. 1925. Hakuun yūki [The travel account of a white cloud]. Seinan: Rekika Shoin. . 1928. "A Study on Kai-ju or Hui-ru," The Great East Culture, 5-12.

Tanaka, Stefan. 1993. Japan's Orient. Berkeley: University of California Press. 
Tanaka Takayuki. 2017. “Japan-Russia Gas Pipeline Mostly a Pipe Dream.” Nikkei Asian Review, 3 August. https://asia.nikkei.com/Politics-Economy/InternationalRelations/Japan-Russia-gas-pipeline-mostly-a-pipe-dream?page $=2$.

Tanami Aoe. 2011. "Chūtō no 'kaku' wo mondai ni suru shiten" [The view that the Middle East's 'nucleus' is the problem]. Impakushon, no. 182 (November): 92101.

Taniguchi Tomohiko. 2006. "Press Conference." Press Conference by the Press Secretary of MOFA, 8 December. Tokyo: Ministry of Foreign Affairs, Japan. https://www.mofa.go.jp/announce/press/2006/12/1208.html.

Tannenwald, Nina. 1999. "The Nuclear Taboo: The United States and the Normative Basis of Nuclear Non-Use." International Organizations 53, iss.: 433-468.

Teo, Victor. 2015. "Recalibrating Sino-Japanese Relations for a Better Future: Implications of Japan's Joint Anti-Piracy Operations in the Gulf of Aden with China," in Japan Viewed from Interdisciplinary Perspectives: History and Prospects. Edited by Sugita Yoneyuki. Lanham, MD: Lexington Books, 169-90.

Thelen, Kathleen. 1999. "Historical Institutionalism in Comparative Politics." Annual Review of Political Science 2: 369-404.

Theodoulou, Stella Z. 2002. Policy and Politics in Six Nations: A Comparative Perspective on Policy Making. Upper Saddle River, NJ: Pearson Education, Inc.

Thompson, Mark R. 2015. "Democracy with Asian Characteristics." The Journal of Asian Studies 74, no. 4 (November): 875-87.

Tjandraningsih Christine T. 2009. "Japanese Recounts Role Fighting to Free Indonesia." Japan Times, 9 September. https://www.japantimes.co.jp/news/2009/09/09/national/japanese-recounts-rolefighting-to-free-indonesia/\#.WuiwqExFyP8.

Togawa Kenichi. 1998. Jidōsha sangyō no jōmyakubu: jidōsha risaikuru ni kan suru keizai chirigakuteki kenky $\bar{u}$ [The vein of the automotive industry: economic geographical research into automobile recycling]. Tokyo: Daimeidō, 1998.

Togawa Masato and Tomomatsu Atsunobu. 2011. Nihon no ODA no kokusai hyōka [International assessment of Japan's ODA]. Tokyo: Fukumura Shuppan, Inc.

Towler, Brian F. 2014. The Future of Energy. Waltham, MA: Elsevier Inc.

Tripp, Charles. 2006. Islam and the Moral Economy. New York: Cambridge University Press. 
Tsukioka Takashi. 2017. "Islamic Finance \& Markets." Getting the Deal Through (September). Nagashima Ohno \& Tsunematsu Law Firm. https://gettingthedealthrough.com/area/58/jurisdiction/36/islamic-financemarkets-2017-japan/.

Tsygankov, Andrei. 2013. Russia's Foreign Policy: Change and Continuity in National Identity ( $3^{\text {rd }}$ ed.). Lanham, MD: Roman \& Littlefield.

Tuan, Yi-Fu. 1974. Topophilia: A Study of Environmental Perception, Attitudes, and Values. New York: Columbia University Press.

Tuke, Victoria. 2013. “Japan’s Crucial Role in Afghanistan.” Asia Pacific Bulletin no. 206 (10 April). https://www.eastwestcenter.org/system/tdf/private/apb206_0.pdf?file=1\&type=no de\&id=34003.

Tuzmen, Melih. 2013. "Nov. 2013-Turkey: Car Market Statistics.” Otomotıv Blog, 15 December. https://otoblog.blogspot.com/2013/12/turkey-car-market-statisticsbest.html.

Uyama Tomohiko. 2008. "Japan's Diplomacy towards Central Asia in the Context of Japan's Asian Diplomacy and Japan-U.S. Relations," in Japan 's Silk Road Diplomacy: Paving the Road Ahead, edited by Christopher Len, Uyama Tomohiko, and Hirose Tetsuya, 101-20. Washington, DC: Central Asia-Caucasus Institute \& Silk Road Studies Program.

Vandenbrink, Rachel. 2012. “Uyghur Conference Sparks Japan-China Row,” Radio Free Asia. https://www.rfa.org/english/news/uyghur/tokyo-05182012185741.html.

KingstonWada Takahiko, and Bernardo Vizcaino. 2015. “Japan's FSA Explores Opening Market to Islamic Finance.” Reuters, 26 February. https://www.reuters.com/article/islam-financing-japan/japans-fsa-exploresopening-market-to-islamic-finance-idUSL5N0W03Z420150226.

Wallace, Mark. 2015. Interview with Pamela Engel. "These Toyota Trucks are Popular with Terrorists - Here's Why.” Business Insider, 7 October. www.businessinsider.com/why-isis-uses-toyota-trucks-2015-10.

Wallerstein, Immanuel. 1974. The Modern World System. New York: Academic Press. 1991. Geopolitics and Geoculture. New York: University of Cambridge. .2004. World-Systems Analysis: An Introduction. Durham, NC: Duke University Press. 
Weems, Philip, and Nina Howell. 2014. "Japan's Pivotal Role in the Global LNG Industry’s 50-Year History.” King \& Spalding Energy Newsletter, August.

Wiederkehr, Stefan. 2007. Die Eurasische Bewegung [the Eurasian movement]. Köln, Weimar, Wien: Böhlau Verlag.

Wike, Richard, Katie Simmons, Bruce Stokes, and Janell Fetterolf. 2017. "Globally, Broad Support for Representative and Direct Democracy.” Washington, D.C.: Pew Research Center.

Willumsen, Torgeir, and Johan-Petter Tutturen. 2014. "Why the Sun Has Yet to Set on Japanese Shipbuilding." Seatrade Maritime News, 27 February. www.seatrademaritime.com/news/asia/why-the-sun-has-yet-to-set-on-japaneseshipbuilding.html.

WITS. 2017. Trade Stats Database, World Integrated Trade Solution. http://wits.worldbank.org/Default.aspx?lang=en.

WNA. 2018. "Information Library." World Nuclear Association. http://www.worldnuclear.org/information-library.aspx.

Wood, Alan T. 2004. Asian Democracy in World History. New York: Routledge.

Woodall, Brian. 2014. Growing Democracy in Japan. Lexington, KY: The University Press of Kentucky.

World Energy Council. 2017. "Gas in United Arab Emirates,” Data. London: World Energy Council. https://www.worldenergy.org/data/resources/country/unitedarab-emirates/gas.

Worringer, Renée. 2007a. "Introduction," in The Islamic Middle East and Japan, edited by Renée Worringer, 1-9. Princeton, NJ: Markus Wiener Publishers.

2007b. "Japan's Progress Reified: Modernity and Arab Dissent in the Ottoman Empire," in The Islamic Middle East and Japan, edited by Renée Worringer, 91-119. Princeton, NJ: Markus Wiener Publishers. 2014. Ottomans Imagining Japan. New York: Palgrave Macmillan.

Wu, Wendy. 2016. “China's Bullet Trains in Race to Win Global High-Speed Rail Market." South China Morning Post, 27 June. http://www.scmp.com/news/china/diplomacy-defence/article/1981926/chinasbullet-trains-race-win-global-high-speed-rail. 
Wu Xinbo, 2016. "Cooperation, Competition and Shaping the Outlook: The United States and China's Neighborhood Diplomacy." International Affairs 92, iss. 4: 849-67.

Xinhua. 2015. "China Unveils Action Plan on Belt and Road Initiative," shared at The State Council, The People's Republic of China, 28 March. http://english.gov.cn/news/top_news/2015/03/28/content_281475079055789.htm.

Yamakage Motohisa. 2006. The Essence of Shinto. Translated by Mineko S. Gillespie, Gerald L. Gillespie, and Komuro Yoshitsugu. Tokyo: Kodansha International, Ltd.

Yamagata Atsushi. 2017. "Conflicting Japanese Responses to the Syrian Refugee Crisis." The Asia-Pacific Journal - Japan Focus 15, iss. 24, no. 2 (14 December): 1-29.

Yamamoto Takehiko. 2015. "Shūdanteki jieiken no nani ga mondai ka" [What is the problem with the right to collective self-defense]? In Shüdanteki jieiken to isuramu-tero no hofuku [Right to collective self-defense and the retaliation of Islamic terrorism]. Edited by Miyata Osamu, Yamamoto Takehiko, Kimura Shūzō, and Mizutani Makoto. Tokyo: Seitōsha,

Yamauchi, Masayuki. 2006. "Nihon to isurāmu: terorizumu no hitei, bunka kōryū - taiwa no zōshin" [Japan and Islam: negating terrorism, and promoting cultural exchange and dialogue]. Sekai Keizai Jihō [World economic news report], no. 151 (February): 1-3.

. 2010. "Japan Needs Mideast-Focused Grow." Daily Yomiuri and the Yomiuri Shimbun (Tokyo, Japan), 13 April.

Yamawaki Hideki. 2007. Japanese Exports and Foreign Direct Investment: Imperfect Competition in International Markets. New York: Cambridge University Press.

Yanagihara Toru, and Anne Emig. 1991. “An Overview of Japan’s Foreign Aid,” in Yen for Development: Japanese Foreign Aid and the Politics of Burden-Sharing, edited by Shafiqul Islam, 37-69.

Yergin, Daniel. 1993. The Prize: The Epic Quest for Oil, Money \& Power. New York: Simon \& Schuster.

Yoshimura Shintarō. 'Iran 'kaku kaihatsu' giwaku no haikei to tenkai: reitetsu na genjitsu no shosō wo misuete" [Background and developments in Iran's 'nuclear development' doubts: looking at a cool-headed reality's aspects of language], in Ajia no "kaku" to watashitachi: Fukushima wo mitsumenagara ["Nuclear" Asia and us: while considering Fukushima]. Edited by Takahashi Nobuo. Tokyo: Keio University Press, 201-29. 
Yoshitsu, M.M. 1984. Caught in the Middle East: Japan's Diplomacy in Transition. Lexington, MA: D.C. Heath and Co.

Yung, Betty. 2012. "Road to Good Governance and Modernization in Asia: 'Asian Values' and/or Democracy?" Journal of Asian Public Policy 5, no. 3 (November): 266-76.

Zaeef, Abdul Salam. 2010. My Life with the Taliban. Translated by Alex Strick van Linschoten and Felix Kuehn. New York: Oxford University Press. 
VITA

\section{BILL BRYAN BARBER IV}

BORN: Norman, Oklahoma

December 2001

Bachelor of Arts in Geography

University of Central Oklahoma

Edmond, Oklahoma

December 2007

Master of Sciences in Geography

Oklahoma State University

Stillwater, Oklahoma

May 2015

Master of Arts in Asian Studies

Florida International University

Miami, Florida

2002-2004

2004-2006

Graduate Teaching Assistant

Oklahoma State University

Stillwater, Oklahoma

JET Programme Assistant Language Teacher

Kitaakita City Board of Education

Kitaakita City, Akita Prefecture, Japan

2006-2009

JET Programme Prefectural Advisor

Akita Prefecture Board of Education

Akita City, Akita Prefecture, Japan

2010-2011

Student Affairs Administrator

Akita International University

Akita City, Akita Prefecture, Japan

2011-2013

Managing Consultant

Interac Co., Ltd, Morioka Branch

Morioka City, Iwate Prefecture, Japan

2014-2015

Krell International Relations Scholarship Recipient

Florida International University

Miami, Florida

2015-2019

Graduate Teaching Assistant

Florida International University

Miami, Florida 


\section{PUBLICATIONS AND PRESENTATIONS}

Barber IV, B. Bryan (November 2014). Sievement: Japan's 'Containment' of China. Paper presented at the 2014 ISAC-ISSS Conference in Austin, Texas.

Barber IV, B. Bryan (October 2015). Comprehensive Security 2.0: (Re)applying a Distinctive Security Concept to the 3/1 1 Disasters in Japan. Paper presented at the 2015 ISA South Conference in Tampa, Florida

Barber IV, B. Bryan (April 2016). Japan and Islam: Inter-Civilizational Relations in Time and Space. Paper presented at the 2016 ISA Convention in Atlanta, Georgia.

Barber IV, B. Bryan (August 2016). Comprehensive Security 2.0: (Re)applying a Distinctive Security Concept to the 3/11 Disasters in Japan. Electronic Journal of Contemporary Japanese Studies, Vol. 16, Iss. 2.

Barber IV, B. Bryan (February 2017). Far, yet so Near: Normativity in Japan's Diplomacy with the Central Asian Republics. Paper presented at the 2017 ISA Convention in Baltimore, Maryland.

Barber, B. Bryan (February 2018). Far, yet so Near: Normativity in Japan's Diplomacy with the Central Asian Republics. Asian Affairs: An American Review, Vol. 45, No. 1: 18-39.

Barber, B. Bryan (March 2018). Japan and Islam in Asia: Discovery, Identity, and Perceptions. Invited lecture at the 2018 Southern Japan Seminar in Miami, Florida.

Barber IV, B. Bryan (March 2018). Japan's Resistance to Remilitarize: How SocioReligious Milieu Affects Perceptions of Security. Paper presented at the 2018 ISA Convention in San Francisco, California.

Barber, Bryan (November 2018). From Gulf Trauma to Proactive Pacifism: Japan's Roles in Middle East Sanctions and Interventions. Presented at University of Nevada-Reno

Barber IV, B. Bryan (March 2019). Strategizing Asia: Japan's Values-Based Diplomacy amid Great Powers' Competing Visions for Broader Asia. Paper presented at the 2019 ISA Convention in Toronto, Ontario.

Barber IV, B. Bryan (March 2019). A Dialogue between Civilizations: Japan's ValuesBased Diplomacy in the Muslims World. Paper presented at the 2019 ISA Convention in Toronto, Ontario. 